\title{
Identifikacija hidroloških režima otjecanja u kršu konceptualnim i parametarskim modelima
}

\section{Željković, Ivana}

Doctoral thesis / Disertacija

2015

Degree Grantor / Ustanova koja je dodijelila akademski / stručni stupanj:

University of Split, Faculty of Civil Engineering, Architecture and Geodesy / Sveučilište u Splitu, Fakultet građevinarstva, arhitekture i geodezije

https://doi.org/10.31534/DocT.038.Zeljl

Permanent link / Trajna poveznica: https://urn.nsk.hr/urn:nbn:hr:123:692221

Rights / Prava: In copyright/Zaštićeno autorskim pravom.

Download date / Datum preuzimanja: 2023-04-26

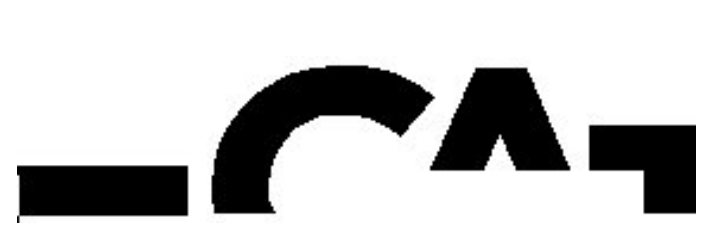

Repository / Repozitorij:

FCEAG Repository - Repository of the Faculty of Civil Engineering, Architecture and Geodesy, University of Split

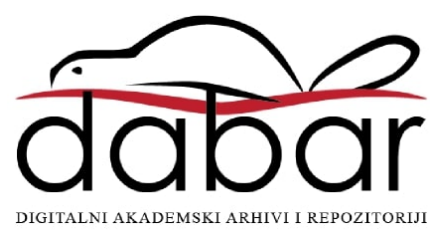




\section{Sveučilište u Splitu FAKULTET GRAĐEVINARSTVA, ARHITEKTURE I GEODEZIJE}

Ivana Željković, dipl.inž.građ.

\section{IDENTIFIKACIJA HIDROLOŠKIH REŽIMA OTJECANJA U KRŠU KONCEPTUALNIM I PARAMETARSKIM MODELIMA \\ Disertacija}

Split, 2015. 
Ivana Željković

Redni broj: 38 .

Ova disertacija predana je na ocjenu

Fakultetu građevinarstva, arhitekture i

geodezije Sveučilišta u Splitu u svrhu

stjecanja akademskog stupnja doktora

tehničkih znanosti $\mathrm{u}$ znanstvenom polju

građevinarstvo.

Mentor: $\quad$ Prof. emer. dr. sc. Ognjen Bonacci, dipl. ing. građ.

\section{Povjerenstvo za ocjenu:}

Dr. sc. Amira Galić, dipl. ing. geol.

Prof. emer. dr. sc. Ognjen Bonacci, dipl. ing. građ.

Dr. sc. Nikša Jajac, dipl. ing. građ. 
Povjerenstvo za obranu:

Dr. sc. Amira Galić, dipl. ing. geol.

Prof. emer. dr. sc. Ognjen Bonacci, dipl. ing. građ.

Dr. sc. Nikša Jajac, dipl. ing. građ.

Rad je obranjen dana: 26. kolovoza, 2015.

Tajnica:

Saša Delić, dipl. iur. 
Rad sadrži:

133 stranice teksta

67 crteža

33 tablice

229 referenci 
Zahvala:

Ovom prilikom željela bih izraziti zahvalu prije svega mentoru prof. emer. dr. sc. Ognjenu Bonacciju na vođenju, podršci i strpljenju tijekom izrade ove disertacije. Bez njegovih kršnih $i$ životnih mudrosti ovaj rad ne bi bio moguć. Zahvaljujem prof.dr.sc. Vesni Denić-Jukić na svesrdnoj pomoći prilikom izrade znanstvenog rada koji je dio ovog doktorata - njeni konstruktivni komentari i savjeti uvelike su mi pomogli. Nadalje, željela bih zahvaliti i članovima Povjerenstva za ocjenu rada-dr.sc. Amiri Galić i dr.sc. Nikši Jajcu na uloženom vremenu i trudu za čitanje i usavršavanje rada. Ne smijem zaboraviti ni kolege Morenu Galešić i Vladimira Divića koji su mi pružili pomoć pri izradi doktorata te Gorana Vlastelicu koji me uputio u tajne FTJP problema. Također zahvaljujem svim institucijama - DHMZ, FHMZBiH, Hrvatske vode i EHZHB na ustupljenim podacima potrebnim za izradu disertacije. Na kraju zahvala najbližima ali ne i najmanje važnimaLidiji za duhovnu i tjelesnu hranu te Ratku koji je i ovu oluju prebrodio sa mnom iz koje ćemo isploviti puna srca, jači i mudriji nego prije. 
Ivana Željković, dipl. inž. građ.

\title{
IDENTIFIKACIJA HIDROLOŠKIH REŽIMA OTJECANJA U KRŠU KONCEPTUALNIM I PARAMETARSKIM MODELIMA
}

\begin{abstract}
Sažetak
Karakteristike vodne bilance krškog vodonosnika čine različiti oblici tečenja vode na koju osim količine padalina utječu kompleksni heterogeni hidrogeološki procesi koji su najčešće direktno ne mjerljivi. Osim problema mjerenja, identifikacija hidroloških režima postaje teža ukoliko su i postojeća mjerenja oskudna i ne kontinuirana. Unatoč konstantnoj nesigurnosti u predviđanju prirodnih pojava, matematički je moguće modelirati procjenitelje koji analiziraju postojeće stanje sustava te dati naznaku trenda njihovih glavnih obilježja. Studije odnosa padalina i oborina tzv. rainfall-runoff (RR) modeli dolaze sve više do značaja zbog boljih mogućnosti implementacije postojećih podataka. RR modeli čine skup različitih matematičkih principa koji u sumi pokušavaju opisati karakteristike riječnog bazena sa određenim pretpostavkama temeljenima na procesnim parametrima kao što su oblik krivulje recesije, površina otjecanja, odnos brzog i sporog otjecanja, količina vode u tlu i slično. Ukoliko se parametri uspješno kalibriraju i testiraju mogu dobiti traženi smisao u vidu opisivanja regionalnih karakteristika područja. Kalibrirani model predstavlja ponašanje hidrološkog sistema pod uvjetima koji su utvrđeni u bazi podataka. Uzimajući ove pretpostavke u obzir, modeliranje kompleksnih krških vodonosnika zahtjeva konceptualni pristup i pristup računalnog učenja. Trenutno dostupna računalna tehnologija postaje sve korisniji alat $u$ analizi procesa za koje je znanje relativno ograničeno jer prije svega značajno smanjuje procesorsko vrijeme računanja te je fleksibilnija i razumljivija krajnjem korisniku. Cilj korištenih modela u ovom radu je pronalaženje ključnih parametara koje određeni model koristiti za uspješno opisivanje promatranih pojava. Iskorištena je mogućnost konceptualnog modela da se jednostavnim transfer funkcijama simuliraju različiti režimi otjecanja u koje je ugrađena informacija o načinu formiranja krivulje recesije kao i stanje količine vode $u$ tlu. S druge strane parametarski model ne daje uvid u načina transformacije podataka, traži sustavan pristup određivanju njegove strukture ali daje veću točnost u usporedbi sa konceptualnim modelima. Implementacija korisnih saznanja o dinamici kretanja vode pomoću oba modela stvorila je bolju sliku dosad hidrološki neistraženog područja u kršu.
\end{abstract}

Ključne riječi: hidrologija krša, RR modeli, vodna bilanca, obrada podataka, sustavni pristup 
Ivana Željković, dipl. inž. građ.

\title{
IDENTIFICATION OF HIDROLOGICAL REGIMES IN KARST WITH CONCEPTUAL AND PARAMETRIC MODELS
}

\begin{abstract}
Summary
Water balance characteristic of karst aquifer consist of different water regime flows influenced not only with amount of precipitation but especially with heterogenic and hydrogeological processes which can't be directly measured. Aside from measurement problems, identification of hydrological regime becomes more difficult if the available data is scarce and discontinuous. Although constant uncertainty is always present in predicting natural phenomena, it is possible to model estimators which can be used to analyse current state of the system and give indication trends of their main features. Relations between rainfall and runoff, the RR model, are becoming more prominent because of their capabilities to implement noisy data. RR model represents an assembly of different mathematical principles trying to describe functioning of river catchment. RR models use certain assumptions about shapes of recession curve, catchment area, base flow-quick flow ratio, soilmoisture content and so on, to determine key parameters of the water circulation process. If the parameters are successfully calibrated and tested, they can be used as new insight to the properties of regional karst. Then, calibrated model represents hydrological behaviour under conditions determined in available database. Simulation of complex karst aquifer requires conceptual and computational learning approach. Current state of computer technology is becoming ever more useful in analysing processes of limited knowledge especially for the fact that computational time is becoming shorter and available software is more flexible and understandable to end user. Aim of proposed models is defining key factors for successful representation of observed runoff. Conceptual model combines transfer function and imbeds these key factors. Parametric model uses transformation which is not transparent but gives better approximation of cost function. Systematic approach to architectural design of parametric model overcomes these problems. Implementation of new findings from both models gives better hydrological understanding of investigated case study in karst.
\end{abstract}

Key words: karst hydrology, RR models, water balance, data processing, systematic approach 


\section{SADRŽAJ}

\section{UVOD}

1.1. Motivacija i postavljanje teze

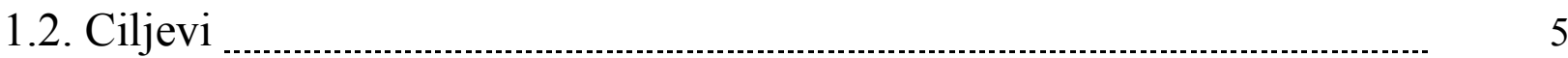

1.3. Modeliranje otjecanja u kršu

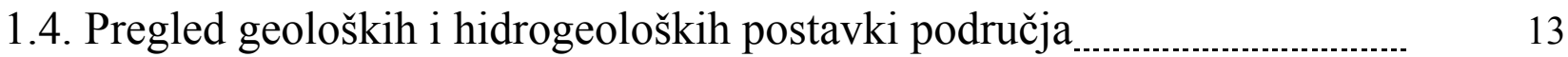

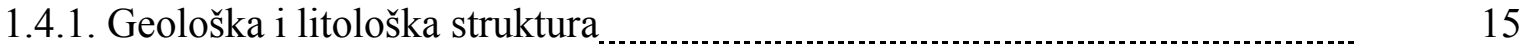

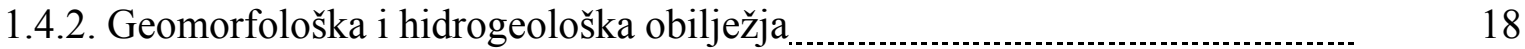

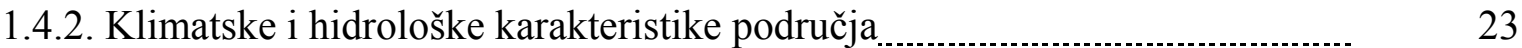

\section{METODE ANALIZE PODATAKA}

2.1. Uvod 26

2.2. Metode obrade i selekcije podataka $\ldots$

2.2.1. Linearna regresija

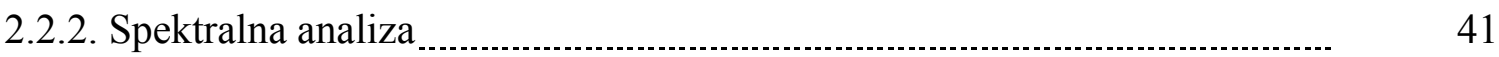

2.3. Rasprava i zaključci

3. IDENTIFIKACIJA HIDROLOŠKIH REŽIMA OTJECANJA

3.1. Uvod 49

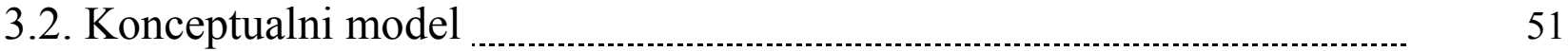

3.2.1. Generalne postavke modela

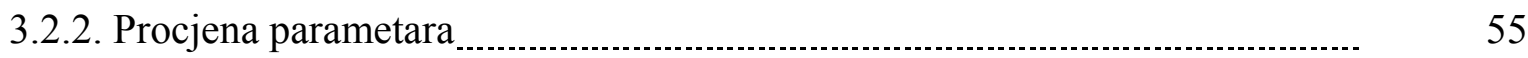

3.2.3. Kalibracija modela

3.2.4. Rezultati 
3.3. Parametarski model $\quad 82$

3.3.1. Postojeća saznanja u istraživačkom području _...................................... 86

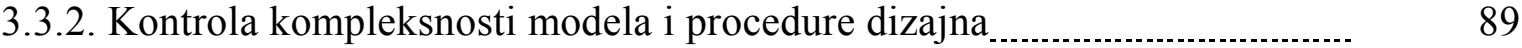

3.3.3. Rezultati

3.4. Usporedba i implementacija modela $\ldots$

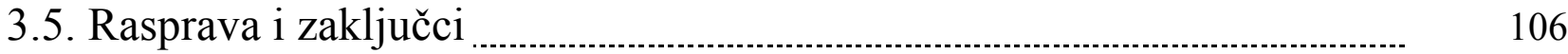

4. ZAKLJUČCI I SMJER DALJNJEG ZNANSTVENOG DJELOVANJA

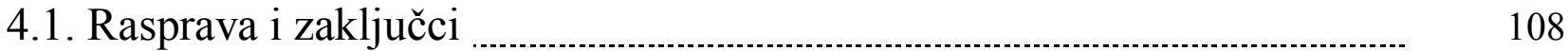

4.2. Znanstveni doprinos i smjer daljnjeg znanstvenog djelovanja $\ldots \ldots \ldots \ldots \ldots \ldots . . . \quad 101$

POPIS SLIKA

POPIS TABLEA

LITERATURA 


\section{UVOD}

\subsection{Motivacija i postavljanje teze}

Određivanje karakteristika vodne bilance u kojoj se uključuju podzemna otjecanja, dotjecanja i gubici ključni su čimbenici u boljem razumijevanju složenih geomorfoloških i hidroloških pojava u kršu. Unatoč konstantnoj nesigurnosti koja postoji u predviđanju prirodnih pojava, moguće je modelirati procjenitelje koji analiziraju postojeće stanje sustava i njegove trendove. U posljednjem desetljeću, studije odnosa padalina i otjecanja tzv. rainfall-runoff (RR) modeli postaju sve više značajni za različite zajednice koje žive uz riječne tokove zbog povećanog razvoja ali i posljedično moguće štete od poplava. Tradicionalno, RR modeli se oblikuju koristeći skup matematičkih principa za opisivanje karakteristika riječnog bazena. Navedeni matematički modeli zovu se konceptualni RR modeli i koriste nekolicinu fizičkih parametara kao što su površina sliva, nagib toka i sl. te procesne parametre npr. vodostaj, koeficijente infiltracije, recesijske koeficijente, količinu vode u tlu itd. koji se moraju definirati zajedno sa ostalim ulaznim varijablama modela. Primjenjivost navedenih modela je često ograničena jer istraživač nailazi na problem pronalaženja jedinstvenog seta parametara koji zadovoljavaju određenu funkciju cilja a značajne korelacije među parametrima ometaju identifikaciju sistema i rezultiraju sa parametrima bez statističke značajnosti. Upitna je i primjena i na slivovima koji nisu istraženi (bez vodomjernih i meteoroloških stanica). Zbog opisanih problema, jednostavni konceptualni modeli, koristeći dostupne podatke, efikasniji su i pragmatičniji za uporabu. Njihova jednostavnost je ujedno i glavna slabost navedenih modela 
jer neizbježno čine pojednostavljenja te je upitna količina dostupnih podataka. Stoga je potrebno istražiti kompromisno rješenje ova dva problema sa modelom koji nisu samo preslika ulaza u izlaze bez ikakvog objašnjenja i koji ne zahtijevaju previše podataka. Razvoj procesorske snage računala otklonio je prepreku u korištenju neuronskih mreža (eng. artificial neural network - ANN) kao novog alata za evaluaciju fizikalnih procesa te je cilj istražiti doseg predloženog modela kroz usvojene metode testiranja, simuliranja i validacije. Značaj ovakvih parametarskih modela postiže se ukoliko se može utvrditi veza postojećih zabilježenih klimatskih karakteristika sa otjecanjem kao i ostalim komponentama kruženja vode te predviđanje budućih vrijednosti otjecanja. Statistički prihvatljivi rezultati simulacija alat su za donosioce odluka u upravljanju i zaštiti vodnih sustava.

Dodatni izazov i motivacija nalazi se u opisivanju otjecanja u heterogenom tipu reljefa kao što je krš. Približno 15\% (Australija) do čak 75\% (Europa) voda koje se koriste u vodoopskrbnim sustavima u svijetu dolazi iz podzemlja (Morris et al. 2003), čime krški vodonosnici obiluju ali je i dalje saznanje o takvim količinama limitirano. Razlog dijelom leži u nemogućnosti detaljnog prikazivanja struktura stjenskih masa kao i u nedostatku adekvatnih podataka kojima bi bilo moguće simulirati otjecanje.

Stoga se postavlja teza da se sa sinergijom saznanja o modeliranju konceptualnim i parametarskim pristupom mogu dobiti nova saznanja o fizikalnim procesima otjecanja vode $u$ kršu. Opseg rada obuhvatit će navedenu problematiku kroz 5 dijelova. U uvodom dijelu će se prezentirati postojeća saznanja o modeliranju otjecanja u kršu sa pregledom geoloških i hidrogeoloških postavki promatranog područja na kojem će se testirati novi model. Drugo poglavlje posvećeno je metodama analize i obrade podataka koje čine osnovu svakog konceptualnog i parametarskog modela jer njihova priprema značajno utječe na kvalitetu modela. Posebnosti korištenja konceptualnih i parametarskih modela $u$ vidu kontrole kompleksnosti te procedure dizajna sustavim pristupom tematika je 3. poglavlja kojoj slijedi modeliranje otjecanja u kojem će se razmatrati efikasnost predloženih modela, moguća implementacija te analiza rezultata $u$ fizikalnom smislu. Zaključci i smjer daljnjeg znanstvenog djevovanja dio su 4. poglavlja. 


\subsection{Ciljevi}

S obzirom na prethodno opisanu problematiku, postavljaju se sljedeći ciljevi istraživanja:

- Prikupiti dostupne literaturne podatke o obavljenim analizama i modelima hidrološkog otjecanja u kršu te protumačiti odnose brzog i sporog otjecanja

- Statističkim metodama utvrditi korelacije između parametara te osmisliti postupak odabira optimalnih parametara za ulazne varijable modela

- Sustavnim pristupom utvrditi postupak modeliranja - pravilni odabir tipa i arhitekture modela, obrade ulaznih podataka, odgovarajući kalibracijski i optimizacijski postupak

- Testiranjem modela uključiti više ulaznih jedinica - konceptualni model testirati kroz ostale izvore koji se pojavljuju u promatranom području i za koje postoji dovoljno dug vremenski period hidroloških i klimatoloških podataka.

- Izvršiti kalibraciju, testiranje i validaciju parametarskog ANN modela uz usporedbu sa konceptualnim modelom pomoću statističkih pokazatelja kao što su ocjena srednje kvadratne pogreške, koeficijent determinacije i koeficijent efikasnosti

- Ispitati mogućnost implementacije postojećeg konceptualnog modela sa predloženim modelom neuralne mreže i njihova usporedba

Prezentirani model također slijedi upute za izradu konceptualnih modela (Van der Beken, 1977):

- model treba predstavljati režim širokog spektra tečenja

- model je moguće primijeniti na različite slivove sa postojećim hidrološkim podacima

- model treba imati fizičko značenje, te uz protok, imati ocjenu površinskog otjecanja, stvarne evaporacije i količine vlage u tlu

- procedura kalibracije treba biti automatizirana ili barem u cijelosti moguća za ponavljanje bez dvosmislenosti. 


\subsection{Modeliranje otjecanja u kršu}

Krš je tip reljefa formiran otapanjem vapnenačkih, dolomitnih i gipsanih stjenskih masa koje formiraju karakteristične podzemne strukture kao što su vrtače, doline i spilje. Cirkulacija vode u kršu, zajedno sa kemijskim i fizikalnim procesima koji se događaju u navedenim formacijama, otvara nove pukotine i lomove u slojevima topivih stijena i time konsonantno mijenjaju hidrološku sliku.

Proces karstifikacije je izazvan kontaktom vode sa topivim i poroznim stijenama (Bonacci, 1987). Intenzivniji tektonski procesi dovode do razvoja veće okršenosti i intenzivnijeg cirkulacije vode. Temperatura vode i obilna precipitacija glavni su uzročnici formiranja krškog terena. Od ostalih faktora, najznačajniji je kemijski sastav vode, brzina vode te klimatski uvjeti. Karstifikacija je pojačana ukoliko postoji i značajniji humusni sloj iznad karbonatnih stijena. Objašnjenje navedenom može se naći u činjenici da deblji sloj humusa proizvodi i akumulira $\mathrm{CO}_{2}$ koji također sudjeluje u otapanju karbonatnih stijena.

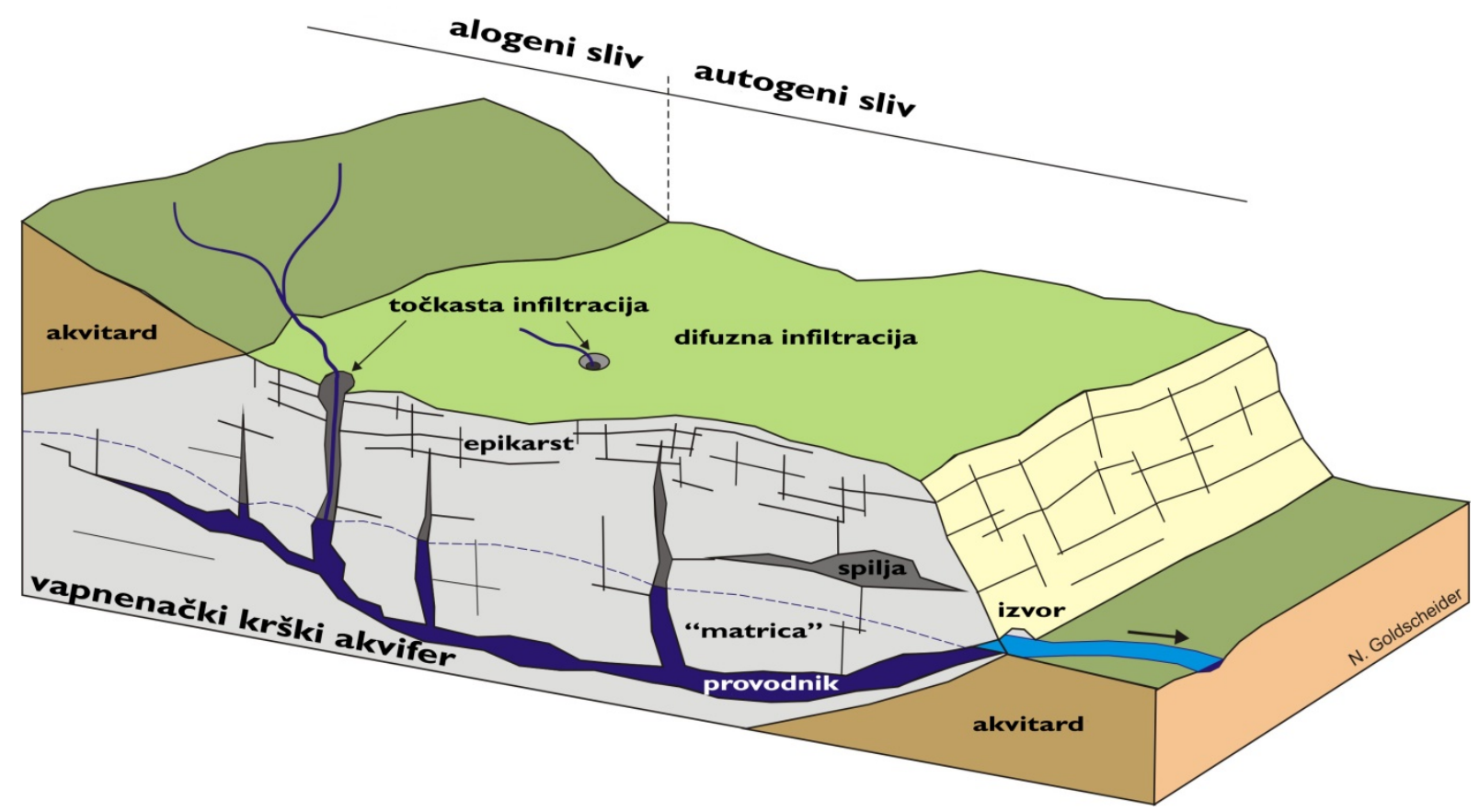

Slika 1.1. Blok dijagram heterogenog krškog akvifera (prema Goldscheider i Drew, 2007) 
Promjenjive i često značajne zemljane formacije su tek dio sistema koji u svom podzemlju skriva mnoge nepoznanice. Zbog kompleksnosti, heterogenosti i anizotropije krški sistemi su slabije razumljiviji od ostalih terena (Bonacci i Roje Bonacci, 2000). Kiraly (1995) iznosi da organizirana heterogenost u mnogim krškim akviferima može biti shematizirana sa gustom mrežom propusnih kanala, širine više kilometara, okružena ispucanim vapnenačkim stijenama slabe propusnosti i dobro povezana sa lokalnim slivom kojeg čini krški sliv. Dualnost krških akvifera (Slika 1.1.) je direktna posljedica ove strukture: dualnost infiltracijskog procesa (difuzna infiltracija u vapnenačkom volumenu slabe propusnosti i visoke brzine u mreži provodnika), dualnost uvjeta otjecanja (difuzno sipanje kroz vapnence i koncentrirano otjecanje kroz kanale) te dualnost uvjeta punjenja - alogeno i autogeno. Većina teoretskih i praktičnih problema u kršu su korelirana i ovisna o organizaciji navedene heterogenosti krškog vodonosnika.

U takvom okruženju količina vode na površini je minimalna i većina tečenja se odvija podzemno (Bonacci, 1987). Površinska hidrografska mreža je slabo razvijena te se na slivnom području tok zadržava u pojedinačnim jačim tokovima. Retencijski kapacitet krša nije velik mnoge studije pokazuju da efektivna poroznost, definirana kao odnos volumena vode u tlu u nekom volumenu tla, iznosi u prosjeku od 0,1 do 1 \%. Pojava velikih transportnih provodnika i spilja lokalno mogu izmijeniti ovu karakteristiku. Dokaz loše retencijske sposobnosti su nagla dizanja i spuštanja podzemnih razina voda koja mogu biti veća i od 100 m. Dinarski krš obiluje ovakvim primjerima - rijeka Cetina pokazuje povećanje razina podzemnih voda brzinom od $2 \mathrm{~m} / \mathrm{h}$ dok je srednja brzina opadanja $0.25 \mathrm{~m} / \mathrm{h}$ (Bonacci, 1993). Ovi podaci ilustriraju specifičnost u količinama transportirane vode u kršu. Fizički i kemijski procesi topivih vapnenačkih i dolomitnih stijena formiraju pukotinske sisteme širina od nekoliko mikrometara do nekoliko metara čime se dobiva dojam velike retencijske sposobnosti. Skladištenje vode u nadslojevima vapnenca i u podpovršinskoj zoni (Ford i Williams, 1989) imaju ključnu ulogu u održavanju sporog recesijskog toka. Kod visokih protoka važno je napomenuti i činjenicu da krške formacije imaju specifičnost ograničavanja vršnih protoka. Maksimalni protok krških izvora ima značajan utjecaj na modeliranje transformacije padalina u otjecanja i jedan je od glavnih uzroka uobičajenih ali često i neočekivanih poteškoća prilikom korištenja konvencionalnih hidroloških modela u kršu (Bonacci, 2001).

Generalno, postoje dva režima tečenja u kršu (Atkinson 1977; Gunn, 1986; Bonacci, 1993). Turbulentni tok, sličan toku vode u vodoopskrbnom sustavu, pojavljuje se u gornjim slojevima razvijenog krša, takozvani provodnici koji čine glavninu toka u kanalima. U donjim 
slojevima krša u kojima dominiraju manje pukotine i rascjepi, voda teče prema principima Darcy-evog zakona, slično kao i u poroznim medijima i naziva se difuzni tok. Treba naglasiti da postoji esencijalna razlika između sporog (baznog) i difuznog toka kao i toka u kanalima i brzog toka, iako postoje određene zajedničke karakteristike koje se ne mogu ignorirati. Bazni tok predstavlja tečenje vode u podzemlje sporom perkolacijom npr. sporim curenjem kroz manje pukotine, dok brzi tok opskrbljuje krško podzemlje brzom perkolacijom i poniranjem vode kroz dobro razvijeni sistem depresija, jama, vrtača i drugih formacija.

Unatoč pretpostavljenom dvojakom sistemu tečenja, podzemne i površinske vode u kršu se ne mogu odvojeno promatrati ni modelirati jer čine jedinstven promjenjiv sustav. Promjenjivost se očituje kod promjene stanja vodotoka koji povremeno ili stalno mogu gubiti dio vode, presušuju u ljetnim mjesecima ili u sušnom dijelu godine, a u nekim slučajevima imaju i podzeman tok (White, 1988; Ford, 1989; Bonacci et al., 2014).

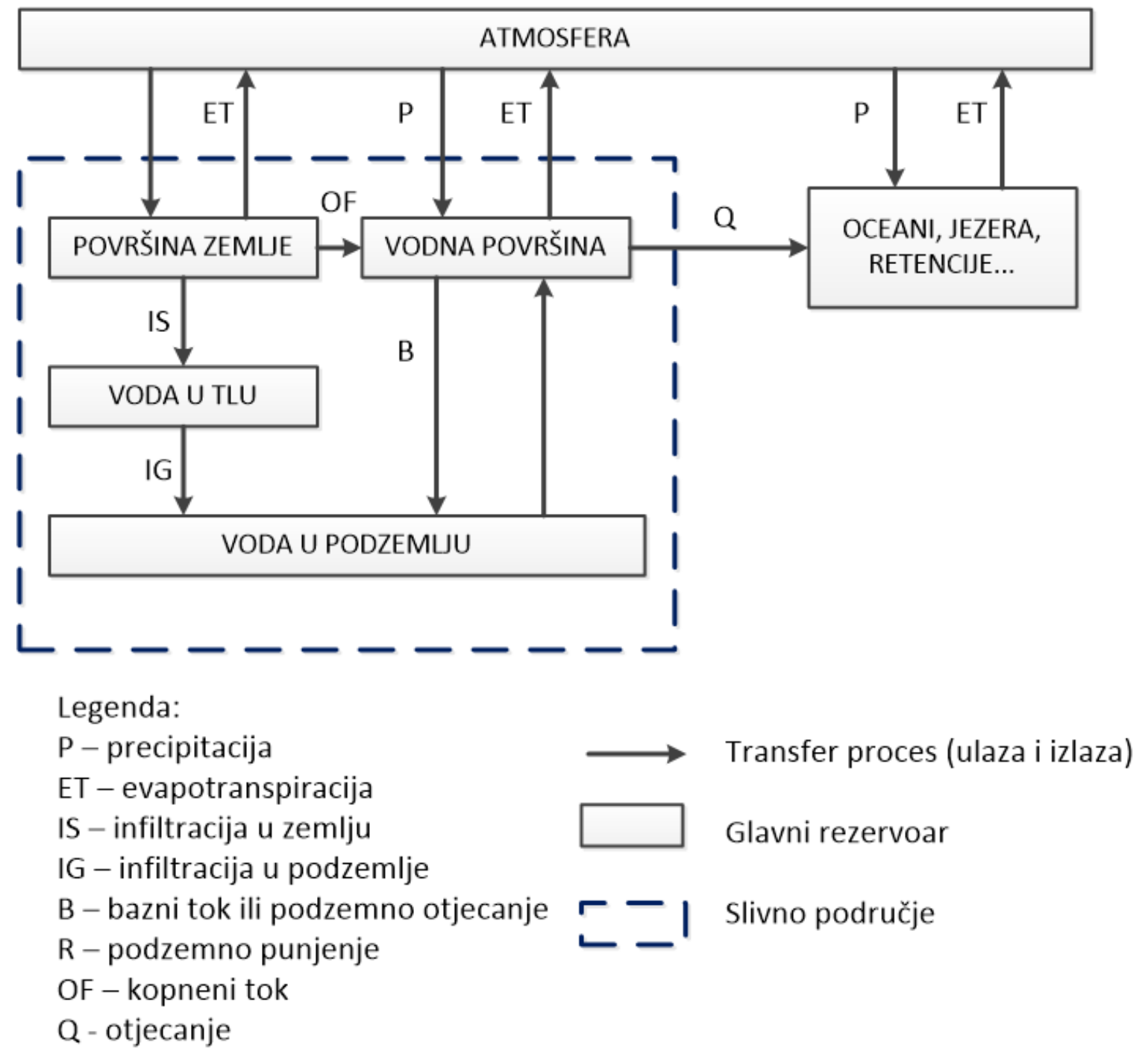

Slika 1.2. Kretanje vlage na Zemlji 
Padaline, otjecanje i evaporacija su osnovni procesi koji transportiraju vodu iz jednog sistema u drugi. Kretanje vlage na Zemlji vrši se u tri sistema: površinskom, potpovršinskom i u dubokim vodonosnicima - akviferima (Slika 1.2). Trajni riječni tok je produkt ovih sistema. U površinskom sistemu padaline, površinsko otjecanje, infiltracija i evapotranspiracija čine dominantne procese koji opisuju kruženje vlage. Vlaga se može izgubiti u atmosferi ili podzemnim procesima. Hidrološki modeli ciljaju na kvantificiranju pojava koje utječu na kretanje vlage kroz različite sisteme. Uzevši to u obzir, odnos padalina i otjecanja je jedan od tipičnih procesa kretanja vlage te modeliranje ovih odnosa je značajan sa različitih znanstvenih gledišta (Singh, 1989). Iako koncept hidrološkog ciklusa zvuči relativno jednostavno, fenomen je enormno kompleksniji i intrigantniji. Ciklus nije jedan i jedinstveni, već se sastoji o više međusobno povezanih manjih sistema kontinentalnog, regionalnog ili lokalnog karaktera. Glavna dostignuća u modeliranju odnosa padalina i otjecanja su stoga bazirana na studiranju samo dijela hidrološkog ciklusa - najčešće površinskog otjecanja. Problem modeliranja je prema tome izražen kao definiranje otjecanja kao funkcije padalina $i$ karakteristika sliva.

Za simulaciju odnosa padalina i otjecanja u krškim sistemima mogu se primijeniti tri tipa modela: teoretski (fizički), konceptualni i black-box tj. parametarski modeli (Denić-Jukić i Jukić, 2003; Fleury et al. 2007; Le Moine et al. 2008; Hartmann et al. 2014). Teoretski modeli bazirani su na hidrauličkim zakonima za različite procese u poroznim medijima (Eisenlohr et al. 1997a, 1997b). Primjena teoretskih modela zahtjeva ekstenzivna hidrološka, geološka i hidrogeološka ispitivanja. Zbog nedostatka ovakvih ispitivanja, konceptualni i black-box modeli se najčešće primjenjuju u simuliranju krških sistema. Za razliku od teoretskih modela, konceptualni modeli pokušavaju opisati fizičke sisteme sa jednostavnim transformacijama ulaznih varijabli u izlazne. Sistem se aproksimira sa različitim podsistemima među kojima se uspostavlja unutarnja struktura. Serije linearnih ili nelinearnih rezervoara su uobičajene strukturne jedinice konceptualnih modela (Halihan i Wicks, 1998; Fleury et al. 2007; Padilla i Pulido-Bosch, 2008; Le Moine et al., 2008; Jukić i Denić-Jukić, 2009; Hartmann et al. 2012; Charlier et al. 2012, Željković i Kadić, 2015). Black-box modeli ne zahtijevaju informacije i poznavanje unutarnje strukture sistema. Oni su bazirani na pronalaženju matematičkih relacija koje će biti najbolje rješenje u procesu uspostavljanja ulazni/izlaznih relacija sistema. Pod black-box modele mogu se uvrstiti analize vremenskih serija (Mangin 1984; Padilla i PulidoBosch, 1995), neuronske mreže (Johannet et al. 1994; Kurtulus and Razack 2006) i upotreba linearnih i nelinearnih funkcija (Jukić and Denić-Jukić 2006; Pinault et al. 2001). 
Hidrološki modeli se nadalje mogu klasificirati kao svedeni (eng. lumped) i distribuirani modeli (Todini, 1988). Svedeni modeli tretiraju sliv kao jednu jedinicu i ne daju informacije od prostornoj distribuciji ulaza i izlaza već samo konačni, prostorno osrednjen odgovor sustava. Naspram svedenim, distribuirani modeli predstavljaju sliv kao sistem međusobno povezanih podsistema tj. pod-slivova koji su organizirani ili u serijsku ili granatu mrežu.

Iako zanimanje za razjašnjavanje pojava hidrološkog ciklusa datira još od davnina, moderne metodologije vezane za padaline i oborine značajnije se razvijaju od 19. stoljeća. Prema Dooge-u (1973), inženjerski pristup modeliranju vodi se idejom da su početni uvjeti na različitim područjima dovoljno slični da se mogu zajednički svesti u empirijske formule. Pojavljuje se termin racionalne metode kao primjer praktične primjene u predviđanju otjecanja kao i modificirana verzija sa izokronama, linijama sa jednakim vremenom tečenja vode, koja predstavlja prvi model baziran na transfer funkcijama. Parametri ovog modela određeni su korištenjem topografskim mapa i Manningove formule. Sherman (1941) uvodi koncept jediničnog hidrograma na principu superpozicije čime svodi sliv na linearni i vremenski neovisni sistem koji vrši transformaciju padaline-oborine. Analiza kompleksnih dinamičnih sistema uz uporabu jediničnog dijagrama i razvoja računalnih modela dovodi do pravog proboja u 50tima. No, derivacija jediničnog hidrograma u diskretnom obliku i dalje predstavlja problem, najviše zbog pretpostavki linearnog ponašanja sistema te neizbježnih grešaka u mjerenim podacima. Nash (1958) oblikuje jedinični hidrogram sa manjim brojem korištenih parametara i time nadilazi navedene probleme. Box i Jenkins (1979) donose alternativne metode za opisivanje hidrograma u obliku autoregresivnog pomičućeg srednjaka (AutoRegressive Moving Average - ARMA). Usporedno se istraživanja sve više okreću fizikalnom razumijevanju hidroloških pojava te se tokom 60tih i 70tih razvijaju konceptualni i svedeni (lumped) modeli: Stanford model IV, Sacramento River, HEC-1 U.S. Army Corps of Engineers, Tank itd. (WMO, 1975) koji unutar svoje strukture aproksimiraju neki od glavnih podprocesa i mehanizama hidrološkog ciklusa. Nedostatak jednoznačnih odnosa modela i realnosti dovodi do razvoja tzv. fizičkih modela kao što je SHE (Abbot, 1986). Četvrta generacija pod nazivom MIKE SHE (Refsgaard and Storm, 1995) osim modeliranja integrira i vodno upravljanje kao što je planiranje vodoopskrbe, navodnjavanja, odvodnjavanja, ekološke faktore, kontrolu kvalitete zemlje i sl. dok SHETRAN uvodi i pronos čestica i sedimenata $u$ riječnom toku (Birkinshaw et al. 2010).

Pristup modeliranju otjecanja u kršu obuhvaća široko područje interesa - istraživanja mogu biti usmjerena za "globalnu" analizu npr. integrirana analiza hidrodinamike krških sistema 
(Kovacs i Sauter, 2007), teoretsko istraživanje evolucije krša (Gabrovsek i Dreybrodt, 2001; Kaufmann i Braun, 2000; Liedl et al., 2003), simulacija kvalitete vode i procjene rizika od zagađenja (Butscher i Huggenberger, 2008; Charlier et al., 2012; Hartmann et al., 2013a) te simulacija hidrološkog ponašanja krša u vidu procjene vodnog kapaciteta krša. Najjednostavniji pristup modeliranja hidrologije krša je aplikacija black-box modela koja najčešće uključuje analitičke transfer funkcije (Jukic i Denic-Jukic, 2006; 2008) ili neuralne mreže (Hu et al., 2008; Kurtulus i Razack, 2006). Primjena teoretskih modela u kršu zahtjeva diskretizaciju u dvodimenzionalnu ili trodimenzionalnu mrežu za koju je potrebno odrediti hidrauličke karakteristike svake ćelije uobičajene veličine od oko 0,01 do $1 \mathrm{~km}^{2}$. Postoje razni načini pristupu prikaza heterogenosti krša unutar distributivnih modela. Equivalent Porous Medium pristup (EPM) pretpostavlja osrednjavanje karakteristika na regionalnoj skali (Loaiciga et al., 2000; Rodríguez et al., 2013) pošto se utjecaj krških provodnika osrednjava na većim površinama (Abusaada i Sauter, 2013), no ovaj pristup ne uzima u obzir brzi tok unutar samih provodnika i time gubi na realističnosti prikaza (Worthington, 2009) te zahtjeva detaljno poznavanje nivoa podzemne vode. Double Continuum pristup (DC) podrazumijeva definiranje interakcije dva kontinuuma - matrice krša i provodnika (Teutsch i Sauter, 1998; Maréchal et al., 2008; Kordilla et al., 2012) ali zahtjeva i detaljno poznavanje geometrije akvifera. Kombinirana diskretno-kontinuirana metoda (CDC) "ugrađuje" provodnike unutar diskretnih elemenata (Kiral i Morel, 1979) čime se dobiva bolja slika prostornog utjecaja provodnika na kršku cjelinu. CDC je korišten u teoretskoj analizi krških procesa, evoluciji krša kao i naširoko korištenom MODFLOW modelu (MODFLOW-CFP, Shoemaker et al., 2008).

Svedeni modeli, kao što su konceptualni model linearnih rezervoara i parametarski model neuronskih mreža koji će biti predstavljeni u disertaciji, opisuju procese u kršu bez eksplicitnog opisivana prostorne varijabilnosti koja je nužna u distribuiranim modelima. Svedeni modeli su bazirani na opisivanju linearnih i nelinearnih odnose između uskladištene vode i otjecanja uz kalibraciju parametara modela koji generalno nisu usporedivi sa terenskim mjerenjima (Wagener i Gupta, 2005). No, svedenost omogućava da se pojedini procesi transporta vode opišu na različite načine i u određenoj dozi detaljnosti. Većina svedenih modela opisuje skladištenje vode u sloj zemlje i epikarsta jednim rezervoarom u kojem je stvarna evapotranspiracija direktna funkcija stanja vlage u tlu dok se punjenje podzemnog rezervoara događa kada vodni kapacitet infiltracija nadvisi kapacitet zemljanog sloja. Koristeći preljevne rezervoare Jukić i Denić-Jukić (2009) su definirali varijacije površina 
slive krškog izvora $\mathrm{s}$ pretpostavkom da promjene dolaze zbog dotjecanja i otjecanja podzemnim tokovima tj. alogenog punjenja. No, većina svedenih modela ne radi razliku između otjecanja van i unutar sliva (Butscher i Huggenberger, 2008; Fleury et al., 2007; Le Moine et al., 2008). Tritz et al. (2011) je u svedeni model krša uključio difuzno punjenje podzemne matrice koja simulira sporo procjeđivanje i producira koncentrirano punjenje kada volumen vode prijeđe aktivacijski prag. Hartmann et al. (2012) je pronašao način opisivanja varijabilnosti karakteristika sloja zemlje i epikarsta definiranjem statističkih distribucijskih funkcija. Osim opisivanja procesa infiltracije, dualnost tečenja unutar krškog vodonosnika predstavlja važan koncept koji se želi predstaviti unutar svedenih modela. Neki modeli koriste sistem sa više rezervoara (Butscher i Huggenberger, 2008; Fleury et al., 2007) drugi uzimaju u obzir matricu rezervoara i definiraju transfer funkcije (Le Moine et al., 2008; Tritz et al. 2011) a koristi se i pretpostavka o dvosmjernoj izmjeni vode između matrice sistema i provodnika (Hartmann et al., 2013b). Svega nekoliko istraživanja uzima u obzir promjenjivost slivne površine (Le Moine, 2007; Jukić i Denić Jukić 2009; Hartmann et al., 2013a) kao i utjecaj preljevnih izvora koji nastaju u propusnim slojevima krša koji su smješteni ispod nepropusne stijenske mase (Rimmer and Salingar, 2006; Tritz et al., 2011; Rimmer and Hartmann, 2012).

Parametri modela u kršu rijetko su direktno mjerljivi sto ga se tipično određuju nekom od kalibracijskih modela. Kalibracija se može vršiti manualno uzimajući u obzir mjerene protoke (Jukić i Denic-Jukić, 2009; Rimmer and Salingar, 2006). Većina istraživanja uključuje definiciju funkcije za ocjenu prilagodbe kao Nash-Sutcliffe koeficijent efikasnosti (Nash i Sutcliffe, 1970) ili modifikaciju iste (Charlier et al., 2012). Svedeni modeli u kršu uključuju samo neke od važnijih procesa koji se žele kalibrirati a razlog tome je izbjegavanje prevelikog broja parametara. Tipično se ne više od 6 parametara procjenjuje tokom procesa kalibracije (Jakemann i Hornberger, 1993).

Veliki broj različitih vrijednosti korištenih parametara nema direktnu relaciju sa karakteristikama promatranog sliva pa se često konceptualni modeli ne mogu regionalizirati tj. primijeniti na šire područje ili na područja slabo pokrivena mjernim instrumentima. Time se dovodi u pitanje pronalaženje jedinstvenog seta koji zadovoljava određenu funkciju cilja, najčešće razliku pogreške između izmjerenih i modeliranih podataka. Visoka korelacija između parametara rezultira slaboj statističkoj značajnosti i isključivo ovisi o samoj jednoj vremenskoj seriji (mjerenom protoku). Ovo istraživanje fokusira se na područja gdje je pronalaženje parametara dodatno otežano zbog slabe rasprostranjenosti mreže vodomjernih i 
klimatoloških stanica, stoga i zahtjeva pragmatično rješenje sa što manje parametara i dobrom konceptualnom podlogom.

\subsection{Pregled geoloških i hidrogeoloških postavki područja}

Rijeke su krvotok krajobraza i slivova, posebice u kompleksnim krškim sistemima i predstavljaju evoluciju hidroloških obilježja krša i njegovo ponašanje uzrokovano djelovanjem složene geomorfologije krša. Područje istraživanja (Slika 1.3) smješteno je na granici između dviju država - Bosne i Hercegovine i Hrvatske. Krajnje sjeverne točke ovog

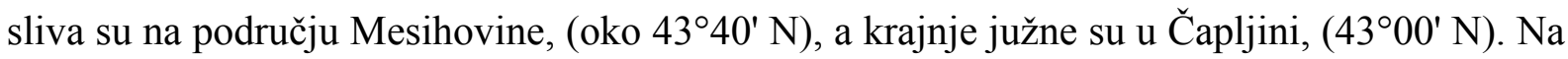
zapad se prostire do zapadnih oboda Imotsko - Grudskog polja $\left(17^{\circ} 00^{\prime} \mathrm{E}\right)$ a na istok do obala

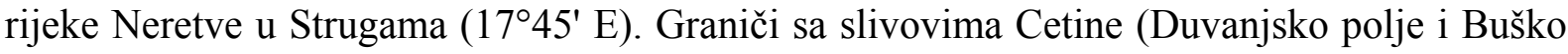
blato), slivom rijeke Drežnice, Ugrovače i Mostarskog blata, a sa južne, odnosno jugozapadne strane, slivom Rastok polja, Vrgoračkog jezera i Jezerca, odnosno neposrednog sliva donje Neretve i Jadranskog mora.

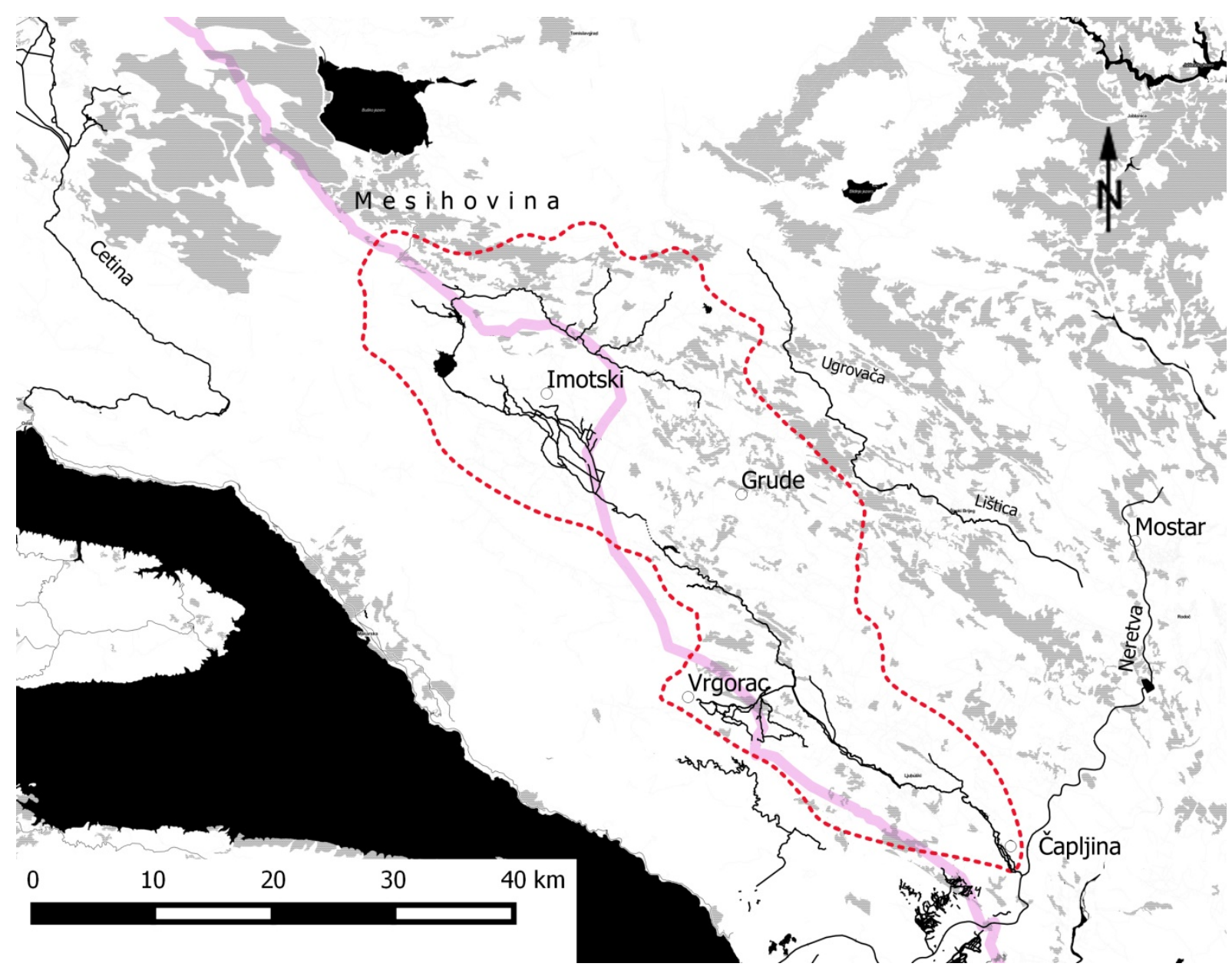

Slika 1.3. Položaj područja istraživanja 
Generalno, svaki krški sliv je jedinstven, a u ovom slučaju to je posljedica duboke i ekstremne regionalne karstifikacija koja uzrokuje pojavu specijalnih oblika u kršu kao i podzemnog sistema provodnika. Glavni tok, dužine oko $106 \mathrm{~km}$ od izvora do ušća rijeke Neretve, mijenja svoje ime 8 tj. 9 puta (rijeka Matica je ujedno i rijeka Vrljika), stoga ne postoji jedinstven naziv za ovaj sliv pa će se u daljnjem tekstu označavati sa "rijeka sa 8 imena". Početak i kraj riječnog sliva nalazi se u Bosni i Hercegovini a tokom kroz Imotsko polje rijeka dijelom prolazi kroz Hrvatski teritorij. Ortografska procjena veličine sliva je oko $1100 \mathrm{~km}^{2}$ čime se prema WFD (Water Framework Directive) klasificira u veće slivove. Sjeveroistočni dio sliva prostire se na padinama planina Zavelim (1347 m), Midena (1224 m), Oštrec (1304 m), Lib planina (1429 m), Štitar (1429 m), Vran (2074 m), Čvrsnica (2222 m) i dijelovima Čabulje, pa se u tom dijelu osjeća utjecaj planinske klime. U središnjem i jugoistočnom dijelu snažan je utjecaj mediteranske klime, koji dolinom Neretve, Trebižata, Mlade i Tihaljine prodire duboko u unutrašnjost. Tu su ljeta duga, suha i vruća a zime obiluju padavinama i blage su.

Određivanje granica sliva i površine sliva u kršu često predstavlja nerješiv zadatak. Razlike topografskog i hidrološkog sliva u krškom terenu su u pravilu toliko velike pa su podaci o topografskom slivu beskorisni u hidrološkoj i hidrogeološkoj analizi (Bonacci 1999; 2007; Bonacci i Andrić, 2008). Generalno, položaj granica sliva ovisi o fluktuacijama nivoa podzemne vode (NPV), posebno u periodima iznenadnih podizanja nivoa (Bonacci, 1987; 1995; 2001). Zbog navedenog razloga, površina sliva se može mijenjati vrlo brzo. U slučaju visokih razina NPV-a preraspodjela površine sliva uzrokovana je otjecanjem u druge slivove. Istražno područje obiluje raznim geomorfološkim formacijama koje su većinom nepoznate te interakcijom propusnih i nepropusnih slojeva u krškom masivu stvara se mogućnost kontakta među izvorima u slivu ili susjednim slivovima. Formacije stvaraju i mnoge neočekivane poveznice riječnih tokova koje se mijenjaju tokom vremena. Nagle promjene na površinskim i podzemnim tokovima posljedica su različitih prirodnih ali i antropogenih utjecaja (Čalić, 2011; Bonacci, 2004a; Beach et al., 2008; Podobnikar et al., 2009). Time se ističe dodatni problem istraživanog područja, koje je tijekom posljednjeg stoljeća doživilo razne antropogene promjene u vidu projekata izgradnje hidroelektrane (HE Peć Mlini), pokušaja razvoja sustava navodnjavanja (rezervoar Ričice), masivnog i nekontroliranog crpljenja vode iz podzemlja, urbanizacija područja itd. Obje zemlje koje dijele sliv, inicirale su i implementirale projekte bez zajedničke sustavne analize i procjene učinka na okoliš čime su neminovno promijenile ekološku sliku ovog krškog vodonosnika. 


\subsubsection{Geološka i litološka struktura}

Specijalni oblici geološke geneze, orogeneze i klimatske geneze nastali u dugoj povijesti regije rezultirali su najrazličitijim geomorfološkim, hidrogeološkim, hidrološki i ekološkim fenomenima u kršu (Redžić et al., 2011) čime zapravo rijeka sa 8 imena predstavlja sistem prekidnog, ponirućeg i podzemnog sustava tečenja. Unatoč obilnim oborinama, mnogi dijelovi analiziranog toka presušuju, a u kratkom dijelu (oko $2 \mathrm{~km}$ ) tok je podzeman. Podzemni tok je utvrđen bojanjem na rijeci Vrljici kroz ponor Šajnovci, nakon kojeg se voda ponovno pojavljuje na izoru Tihaljina (Petrik, 1960). područje obiluje poljima u kršu - velike depresije, ravnog dna, smještene između vapnenačkih stijena - uzduž kojih se nalazi više od 100 privremenih ili stalnih izvora.

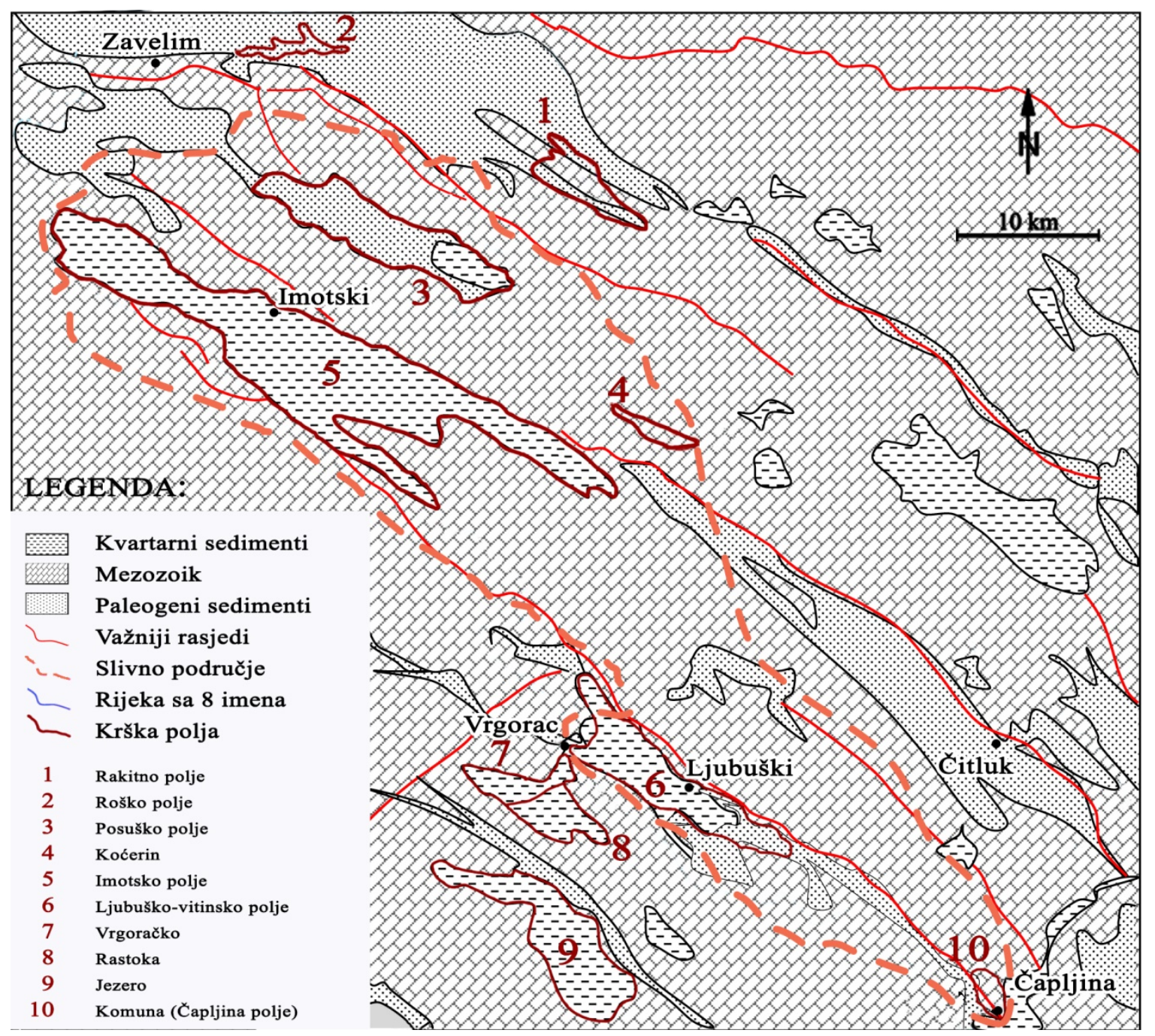

Slika 1.4. Osnovna geološka karta sliva

Rijeka sa 8 imena (Slika 1.4.) dio je tektonske jedinice Vanjskih Dinarida (Herak, 1984). Osnovna strukturno-tektonska obilježja ovog ispitivanog terena su strukture pretežno 
dinarskog pravca pružanja. Jedino u području Raško polje - Mesihovina strukture se pružaju po pravcu zapad-istok. Osi bora i glavni rasjedi su dinarskog pružanja. Rasjedi su često reverznog karaktera pri čemu su stratigrafski starije stijene navučene preko mlađih. Aksijalne ravni nabora najčešće imaju pad prema sjeveroistoku, a bore su raskidane u blokove omeđene, kako uzdužnim tako i poprečnim i dijagonalnim rasjedima. Prostor sliva proteže se kroz četiri strukturno tektonske jedinice: Imotski, Zavelim, Svitav-Ljubuški i Stolac-Čitluk. Granica između Imotske i Zavelimske strukturne jedinice je sustav dubokih rasjeda nastalih tijekom tektonskih zbivanja koja su gipsonosne stijene permotrijaske starosti (najstarije na ovom području) istisnula na površinu kod sela Sobač. Granica između Svitavsko-Ljubuške i Stolačko-Čitlučke tektonske jedinice leži na pravcu Čapljina-Studenci-Ljubuški-Klobuk. Duž ove linije navučeni su vapnenci Čitlučke jedinice na eocenski fliš Ljubuške jedinice. Eocenski fliš je oblika prevrnute sinklinale koja ja podvučena na podleglu antiklinalu ČapljinaLjubuški-Klobuk. Dalje sjeverozapadno Eocenski vapnenci i dolomiti navučeni su na mlađe Kredne vapnence. U području rijeke Tihaljine stvaraju se kraljušti - stijenske navlake koje se prostiru nekoliko desetina kilometara - vapnenci i dolomiti iz razdoblja Krede navučeni si na Eocenske tvorevine.

Sastav stijena na području 8 rijeka različitog je porijekla pa se tako datiraju sedimentne naslage Permo-trijasa, Trijasa, Gornje Jure, Donje i Gornje krede, Paleogena, Neogena i Kvartara (Slišković, 1994).

Najstariji sloj Mezozoika - Trijas (sačinjen uglavnom od dolomita) formira parcijalnu barijeru cirkulaciji vode u području dok je širi utjecaj uočen u čestim tektonskim pomacima koje uzrokuju nastajanje antiklinala, sinklinala, longitudinalnih i transverzalnih rasjeda. Naslage Trijasa najstarije su i najmanje zastupljene i to samo na sjeverozapadu u okolini Posušja i području Ivovika, karakteristične su po naslagama gipsa uz pješčare, škriljce i breče te su podložne dijapirskim procesima. Dijapir (grč. diapeirein - probiti) je geološka struktura sastavljena od mobilnog materijala koji je nabijen u krhke okolne stijene, najčešće protokom prema gornjim slojevima, procesima istisnute su na površinu i izrasjedane. U hidrogeološkom pogledu navedene strukture su većinom vodonepropusne. Zbog sadržaja gipsa i anhidrita imaju utjecaja na mineralizaciju jednog broja izvora i vrela u dolini Tihaljine. Dolomiti i vapnenački dolomiti iz razdoblja Trijasa nalaze se na sjeveroistočnom dijelu terena $u$ izvorišnom dijelu Drežanke.

Vapnenci, dolomiti i njihove kombinacije Jurske starosti dominantne su litološke jedinice koje leže ispod naslaga Gornje i Donje Krede na sjeverozapadnom terenima. Kredni depoziti, 
sastavljeni od slojevitih masivnih vapnenaca sa rijetkim pojavama dolomita, najzastupljeniji su u riječnom bazenu.

Područje je tektonski aktivno, što je rezultat procesa naboravanja slojeva Mezozoika, Paleogena i Neogena. Tektonska aktivnost se pojavljuje u vremenu Gornje Jure i Donje Krede i u tranzicijskom periodu između Gornje Krede i Paleogena kada su formirane osnovne tektonske jedinice koje su svoj maksimalni preobražaj doživile u Gornjem Eocenu. Treba naglasiti da dolomiti nastali u ovom periodu znatno ne ometaju cirkulaciju podzemnih voda (Slišković and Ivičić, 2002).

Većina manjih planinskih jezera formirana je glacijalnim procesima. Predominantna karbonatna struktura vapnenaca i dolomita promjenjiva je u vertikalnom i horizontalnom smislu te time omogućuje povremenu pojavu breča i lapora. Pretpostavlja se da je debljina karbonatnih stijena u nekim dijelovima veća od $300 \mathrm{~m}$.

Kvartarni depoziti protežu se kroz krška polja i uzduž otvorenih tokova. Starije Kvartarne naslage nalaze se u obliku glacijalnih morena u sjevernom dijelu sliva i kao jezerske gline $u$ Imotskom polju te kao šljunčani i glinoviti materijal, negdje do $100 \mathrm{~m}$ debljine, dok su glinovito-laporoviti materijali u Koćerinskom polju vjerojatno manje debljine. Južnije, Kvartarne naslage zastupljene su u poljima Rastok, Jezerac te Vrgoračkom polju. Mlađi Kvartarni depoziti su većinom aluvijalnog podrijetla u obliku pijeska i šljunka. Aluvijalne naslage, osim u Imotskom polju, u značajnijim količinama su uočene i u Rastovačkom polju, dolini rijeke Tihaljine, Vitinsko-Ljubuškom polju, Kočerinu te u koritu i dolini Trebižata sve do ušća u Neretvu. Deluvijalne sedimente u vidu vapnenačkih drobljenaca sa glinom i crvenicom može se naći na prostoru Ljubuško-Vitinskog polja i Komina (SZ od Čapljine). Sedimenti sedre nalaze se u koritu rijeke Trebižat blizu ušća u Neretvu (slapovi Kravice) te na ušću Studen potoka u rijeku Mladu (slapovi Koćuša). Litologija i debljina Kvartarnih naslaga je promjenjiva čime znatno utječe na hidrogeološko funkcioniranje opaženih polja u kršu. Većina depozita utječe na podzemni tok u obliku visećih barijera koje su zabilježene na području Rakitnog, Roškog, Posuškog, Imotskog i Ljubuško-Vitnskog polja (Slika 1.4.). 


\subsubsection{Geomorfološka i hidrogeološka obilježja}

Prirodna obilježja krša rezultat su velikoj broja neovisnih pokretački sila koje djeluju na karbonatne stijene (White, 1988). Faktori i procesi koji utječu na evoluciju krša mogu biti (Čalić, 2011): topografija, litologija, tektonski položaj i aktivnost, hidrološki procesi ovisni o klimi, dinamika otapanja sijenske mase, geomorfološki procesi i antropogeni utjecaji. Među geomorfološkim procesima najvažniji su: atmosferski utjecaji, nagibanja, fluvijalni te glacijalni procesi. Površina i podzemlje krškog krajobraza može evoluirati tokom vremena zbog difuzijskih procesa na manjoj skali, eroziji na većoj skali i denudaciji krša tokom velikih i malih voda (Kaufmann, 2009). Formacije u kršu mogu imati veći ili manji utjecaj na cirkulaciju vode i time utjecati na razvoj hidrološke slike (Goldscheider, 2005; Goepert et al. 2011) promatranog područja gdje se uočavaju svojstveni oblici u okolišu, veličine od veoma malih (mikro-potoci) do ekstremno velikih (velika krška polja i duboke urušene doline izdužena udubljenja na Zemljinoj kori koja su uvijek otvorena u smjeru riječnog otjecanja). Istovremeno, područje je bogato podzemnim geomorfološkim oblicima ispod površine kao što su Crveno i Modro jezero (Slika 1.5.) kao najistaknutije, Begića ponor - podzemna veza Imotsko-Bekijskog polja sa Rastovačkim poljem - trenutno slabo istražen, ponor Šajnovac prirodni podzemni prolaz rijeke Matice do rijeke Tihaljine, Ravlića spilja, Majića ponor, spilje Mala i Velika Studenčica kraj Ljubuškog, slapovi Kravice i Kočuša i mnogi drugi. Glavna prepreka determinaciji cirkulacije vode i održivom gospodarenju voda, pogotovo u vidu objašnjenja međusobnog djelovanja geomorfologije i hidrologije limitirana je dostupnim informacijama o postojećim formacijama. 


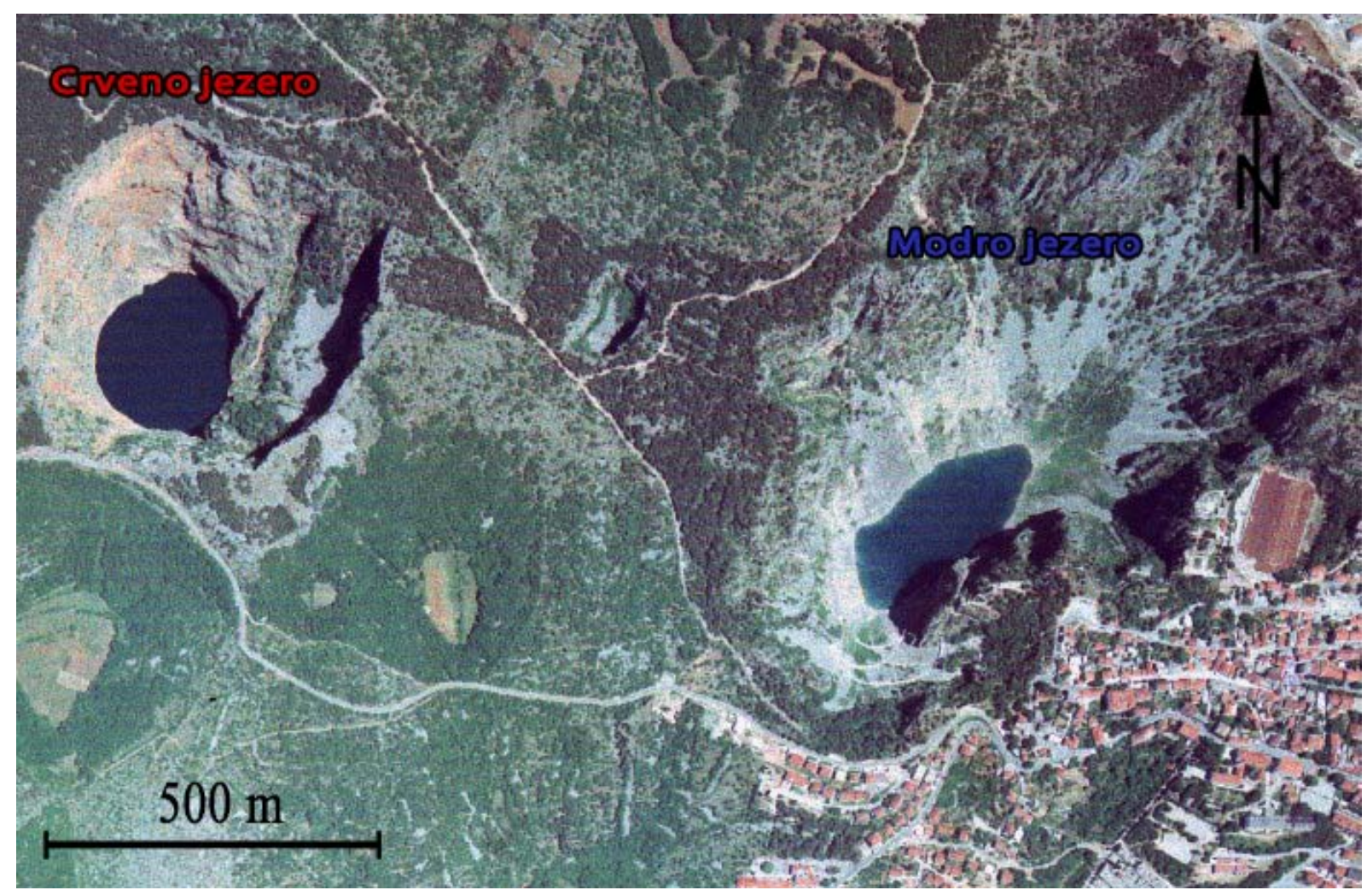

Slika 1.5. Crveno i Modro jezero

Veća polja u kršu (slika 1.4) predstavljaju najvažnije krške formacije koje utječu na hidrološko i hidrogeološko funkcioniranje sistema. Milanović (1995) smatra da regionalni prevrnuti rasjedi učestalo imaju ključnu ulogu u hidrološkoj genezi i kontrolu hidroloških procesa uzduž tektnonskih granica. Na području 8 rijeka zabilježena su sva četiri tipa krških polja (Bonacci, 1987; 2004b): zatvorena, otvorena uzvodno, otvorena nizvodno i otvorena uzvodno i nizvodno. U zadnja dva tipa polja prisutno je i podzemno i površinsko procjeđivanje. Zatvoreni tip polja je najčešće zastupljen. Sa hidrološke perspektive polje se razmatra u širem smislu te se ne može tretirati kao neovisni sistem veći jedino kao podsistem procesa na površini i u podzemlju. Krška polja su redovito poplavljena tijekom hladnih i vlažnim perioda godine. Poplavne zone su varijabilne i ovise o količine padalina tokom hidrološke godine. Poplave u poljima Dinarskog krša u prirodnim uvjetima traju od 3 do 7 mjeseci tokom godine, najčešće u periodu od listopada do travnja. Razlog plavljenu može biti: izdizanje NPV iznad dna polja, pritok vode koji premašuje maksimalni kapacitet otjecajnih struktura (ponora i ponikvi) ili se oba događaja pojavljuju istovremeno. Krška polja na promatranom području položena su između Dinarskih planina pa su stoga pružaju u smjeru sjeverozapad-jugoistok. Kota najvišeg polja je 900 m n.m. a najnižeg 30 m n.m. Imotsko polje sa svojom dužinom od $32.4 \mathrm{~km}$ i površinom od $95 \mathrm{~km}^{2}$ čini najveće polje u slivu. 
Dva posebna fenomena (Slika 1.5.) ističu se na području - Crveno i Modro jezero kraj Imotskog. Bögli (1980) i Williams (2004) opisuju nastanak Crvenog jezera kao kolaps krške doline sa stalnim jezerom na dnu. Za razliku od Crvenog jezera, Modro jezero koje je niti 100 m udaljeno od Crvenog, presušuje prosječno jedanput u 4 godine (Bonacci, 2006; Bonacci i Roje-Bonacci, 2008; Palandačić et al. 2012). Nivo vode u Crvenom jezeru varira od 230.8 do 274.45 m n.m a Modrog jezera od 241 m n.m. (dno jezera, stanje kada je presušeno) do 342 m n.m i time prate oscilacije NPV okolnog akvifera (Bonacci i Roje-Bonacci, 2008). Petrik (1960) pretpostavlja da je završetak Crvenog jezera zapravo vrulja (izvor ispod razine mora) koja je udaljena $23 \mathrm{~km}$ od jezera i na $-35 \mathrm{~m}$ n.m. Voda u gornjoj zoni Crvenog jezera povezana podzemnim provodnikom sa nekoliko trajnih i privremenih izvora $\mathrm{u}$ Imotskom polju (Bojanić et al. 1981). Speleološka ekspedicija (Garašić, 2001) uočila je postojanje podzemne rijeke koja prolazi kroz dno Crvenog jezera na dubini od $6 \mathrm{~m}$ ispod razine mora ali posljednja istraživanja (Andrić et al. 2013) snimila su suspendirane čestice na dubini -4 m n.m koje miruju i ne ukazuju na postojanje aktivnog strujanja.

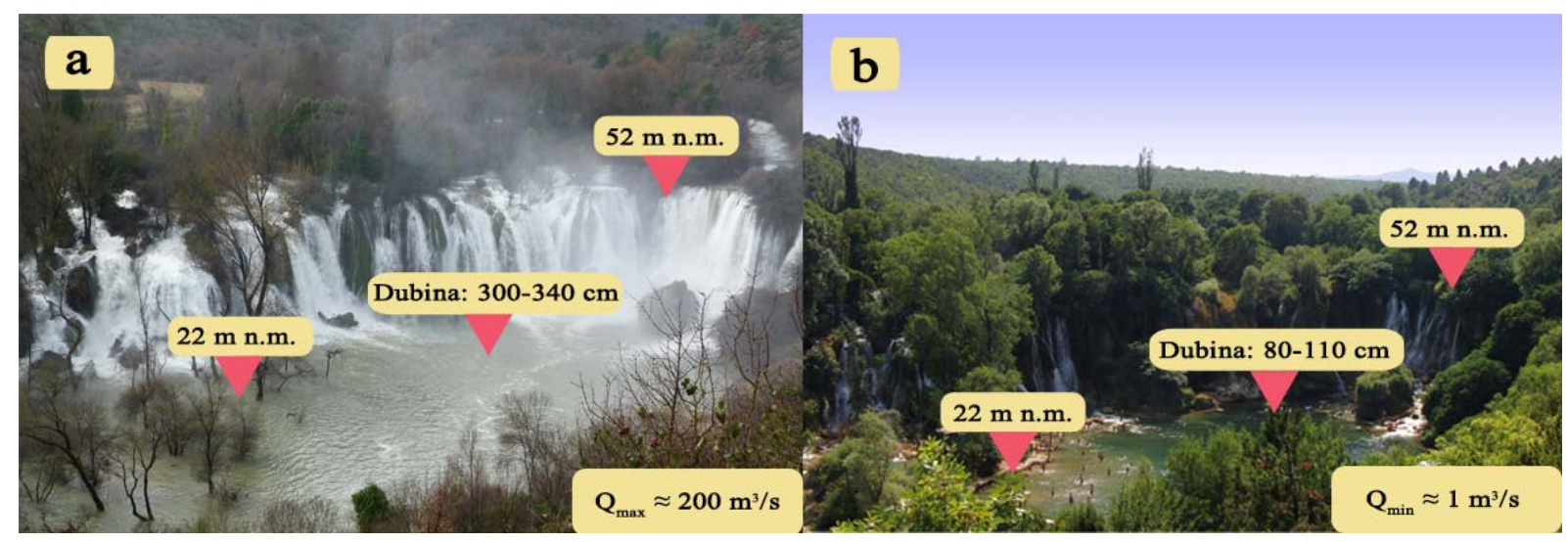

Slika 1.6. Slapovi Kravice u zimskom (a) i ljetnom razdoblju (b)

Od ostalih fenomena, valja spomenuti vodopade Kravice i Kočuša. Oba vodopada su formirana na sedrenim barijerama. Ford i Williams (2007) definiraju sedru kao zrnato taloženje na mjestima gdje vodeni tok gubi kinetičku energiju ili zbog neke prepreke (vodeno bilje) ili zbog smanjenja nagiba. Šupljikava tekstura javlja se zbog toga što se kalcit taloži oko biljaka, a nakon njihovog izumiranja zaostaju šupljine. Kravice (Slika 1.6.a i 1.6.b) pokazuju značajne fluktuacije - protoci se kreću od $1 \mathrm{~m}^{3} / \mathrm{s}$ ljeti do $200 \mathrm{~m}^{3} / \mathrm{s}$ zimi. 


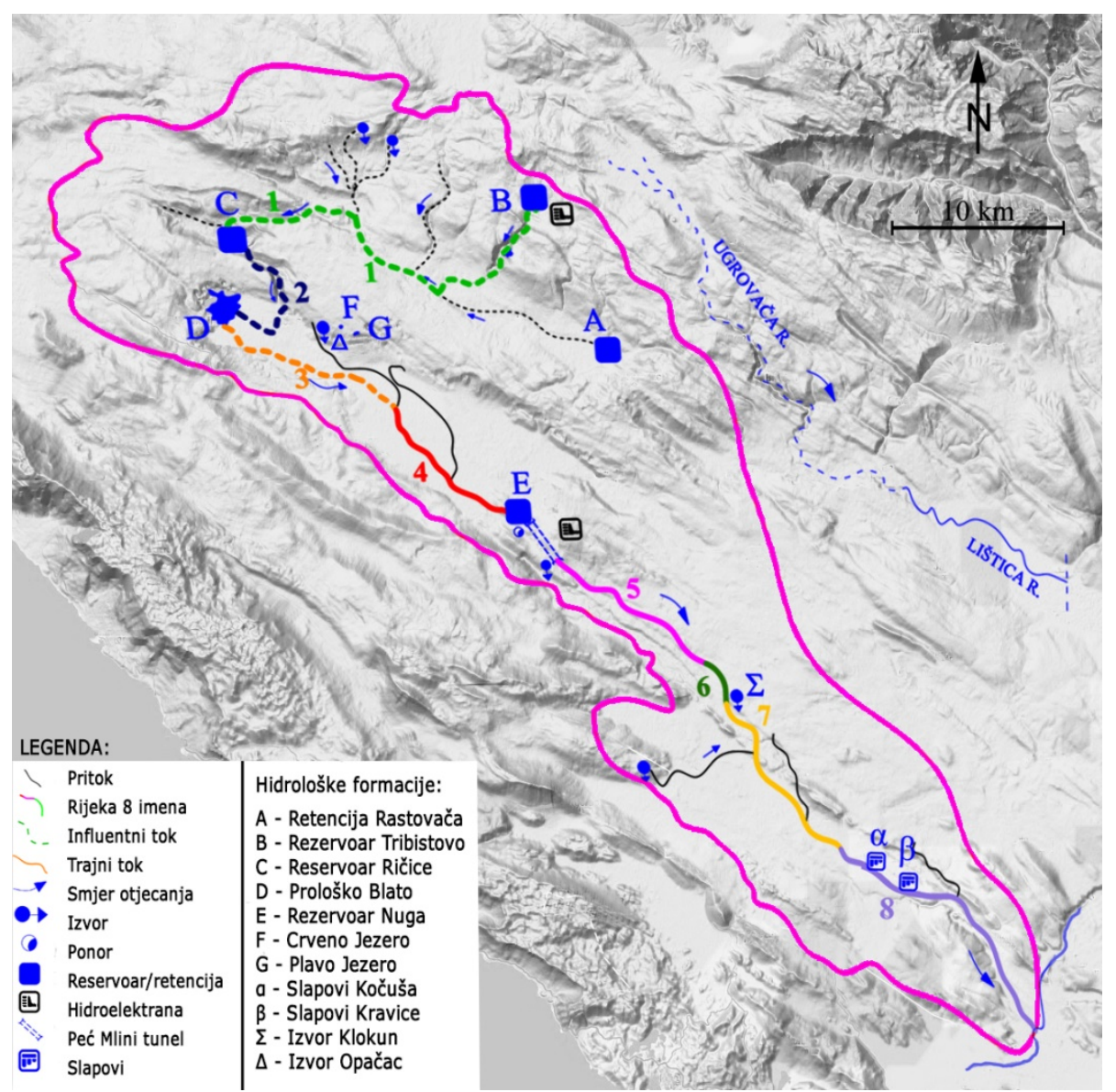

Slika 1.7. Značajnije hidrološke formacije na promatranom području

Značajne hidrološke formacije koje su važne za razumijevanje ovog kompleksnog sustava prikazane su na Slici 1.7. Uočava se da je uzvodni tok rijeke kao i većina pritoka povremen i ponirući tzv. influentni tok a razlog tome je povezanost površinskog i podzemnog toka pri kojem se određene količine vode nepovratno gube. Povremeni riječni tokovi su Ričina (broj 1 na slici 1.7.) koja se formira od stalnih vodotoka Ružičkog i Močila potoka, ali ulaskom u masiv Snježnice i Radovan planine ponire i pri intenzivnijim padavinama u jesen i proljeće protječe osim podzemno i površinski. Isti je slučaj i sa njezinom pritokom Topalom u Posuškom polju. Na svome vodotoku koji je generalno usmjeren u pravcu sjeverozapada Ričina prima Studen potok, koji se u sušnom periodu gubi u gornjem toku, a u Virskom polju potok Žukovicu. Nakon ulaska u polje Ričice, prima desnu pritoku Vrbicu. Tu se nalazi umjetna akumulacija Ričice, odakle samo povremeno površinski teče kroz kanjon Badnjevica te pod imenom Suvaja (2) ulazi u Imotsko polje, gdje je umjetnim koritom uvedena u Prološko blato. Suvaja je povremeni tok i samo pri visokim vodnim valovima teče površinski kratkotrajno do Prološkog blata u zapadnom dijelu Imotskog polja, a odatle otječe prokopanim kanalom Sija (3), te nešto uzvodnije od Kamenmosta utječe u Vrljiku (4). Rijeka 
Vrljika teče od Prološca u sjeverozapadnom dijelu Imotskog polja do krajnjeg jugoistočnog dijela Imotskog polja, do predjela Nuga gdje je smještena još jedna specifična hidrogeološka formacija - podzemni prolaz rijeke Vrljike koja ulazi u ponor Šajnovac te nakon $1500 \mathrm{~m}$ izvire kao rijeka Tihaljina (5) (Slika 1.8.a situacija i 1.8.b presjek). Izvor rijeke Tihaljine formira se u podnožju brda Petnjik (ili Pećnik, po brojnim pećinama) nakon prolaska kroz nepotpunu stijensku barijeru sačinjenu od vapnenaca i dolomita (Slišković, 1994). Na istom mjestu, 2004. godine izgrađena je hidroelektrana Peć Mlini sa hidrotehničkim tunelom duljine $1570 \mathrm{~m}$, promjera $4.4 \mathrm{~m}$, od novonastale akumulacije Nuga do Tihaljine.
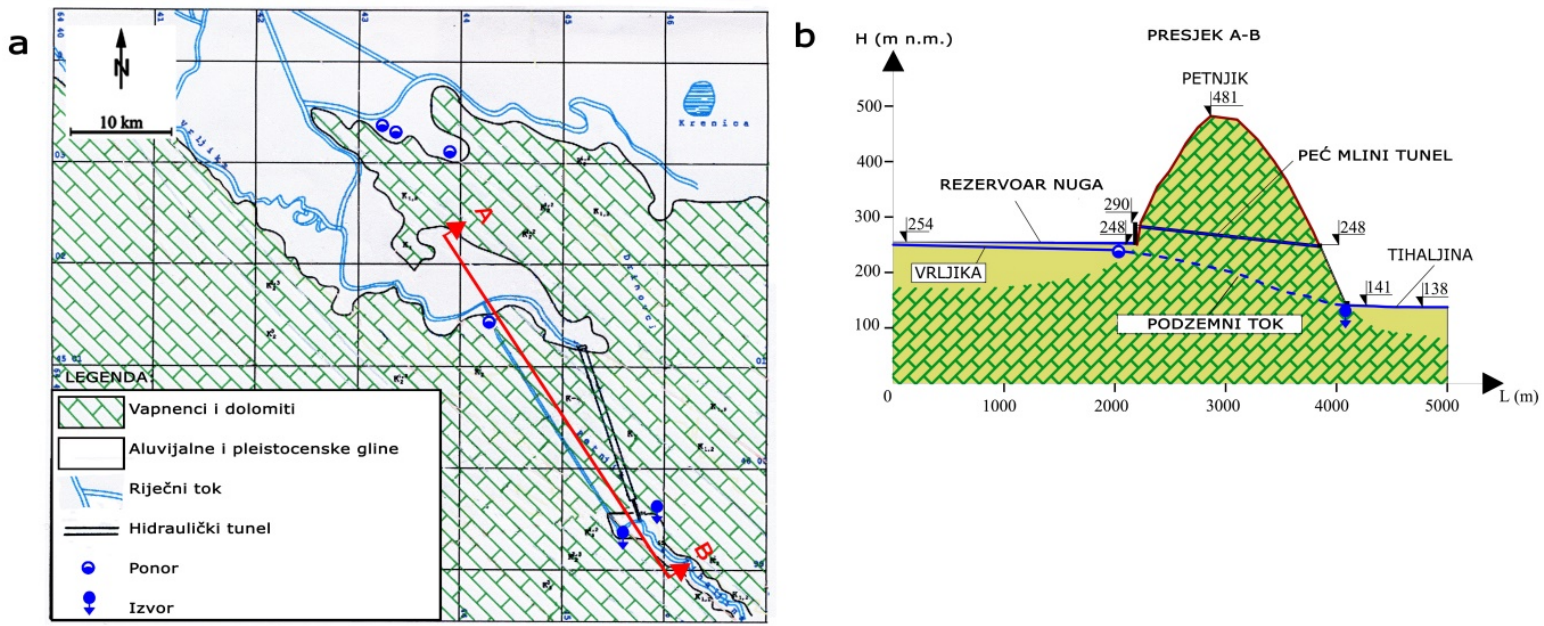

Slika 1.8. Hidrogeologija Peć Mlini

Ime Tihaljina ovaj riječni tok nosi od izvora u Peć Mlinima do Greblja u Mladima. Na tom dijelu lijeve pritoke su kraći vodotoci koji se formiraju na lijevom zaobalju od krških vrela kao što su Krupa, Nevidina, Jakšenica, Nezdravica, a na desnoj obali su Zloriba, Meljava i drugi manji potočići oko Klobuka. Dalje, od izvora Nenač do izvora Klokun, kratkim dijelom rijeka se naziva Sita (6).

Od Greblja pa do Parila pokraj Otoka rijeka zove se Mlade (7), zato što se vodotok "pomlađuje" na tom dijelu iz nekoliko izvorišta a najveće je vrelo Klokun u Klobuku. Na vodotoku Mlade na lijevoj obali su rijeka Vrioštica i potok koji se formira u Donjem Proboju. $\mathrm{Na}$ desnoj obali je povremeni tok Studen potok u polju Kladnik, koji se povremeno aktivira kad proradi kraško vrelo Banja kod Šipovače, a ulijeva se kaskadno kod Koćuše.

Od Humca nizvodno vodotok se zove Trebižat (8), i dolina se sužava a desna obala je strmija od lijeve, koja čini dosta nisku kršku zaravan (80 - 100 m.n.m) Jabuke i Hrašljana. Na vodotoku Trebižata najznačajnija je lijeva pritoka Studenčica kod Studenaca. Ona nastaje od tri vrela: Vrilo, Vakuf, Kajtazovina na kontaktu eocenskog fliša i okršenih krednih naslaga. U 
nju se iz pravca Čitluka ulijeva povremeni vodotok Lukoča i Stube u Čitlučkom polju. Nizvodno od Privorca dolina se jako širi prema ušću u Neretvu. Domaće stanovništvo vrlo često koristi samo termin Rika i to za cijeli vodotok.

\subsubsection{Klimatske i hidrološke karakteristike područja}

Lokacija razmatranih meteoroloških i hidroloških stanica te rezultati trasiranja prikazani su na Slici 1.9. Područje se nalazi na periferiji Mediteranskog klimatskog pojasa sa snažnim utjecajem kontinentalne klime. Jadransko more je svega 10 do $30 \mathrm{~km}$ udaljeno od sliva a barijeru snažnijem primorskom utjecaju čini planinski lanac planine Biokovo (1762 m n.m.). Prosječna godišnja temperatura varira od $8^{\circ} \mathrm{C}$ na sjevernom do $14^{\circ} \mathrm{C}$ na južnom dijelu sa minimalnim dnevnim temperaturama u siječnju od $-10^{\circ} \mathrm{C}$ i maksimalnim dnevnim temperaturama iznad $35^{\circ} \mathrm{C}$ u srpnju i kolovozu. Prilikom analize klimatskih podataka iz perioda 1987. - 1992. uočava trend zagrijavanja - srednja godišnja temperatura zraka je veća za $0.8^{\circ} \mathrm{C}$ u odnosu na razdoblje prije 1987. godine (Bonacci, 2010). Godišnje padaline kreću se od 750 do $2350 \mathrm{~mm}$ - maksimalne količine kiše zabilježene su u listopadu i studenom a minimalne u srpnju i kolovozu. Opadajući trend u količinama oborina zabilježen je kod većine promatranih vodomjernih stanica (razdoblje od 1950. - 2010.).

Rimmer i Salingar (2006) su utvrdili da količina vode na krškim izvorima nije ovisna samo o površini sliva već i od doprinosu podzemnog toka, stoga su serije točkastih (eng. point-topoint) trasiranje potrebne za određivanje mreže podzemnih smjerova vode usporedno sa sistemom površinskih voda (Worthington i Smart, 2003). Svega nekoliko trasiranja izvršeno je na promatranom području, a utvrđene veze prikazane su na Slici 1.9. Vidljivo je da postoje veze ponora van pretpostavljenih granica sliva sa izvorima u slivu. 


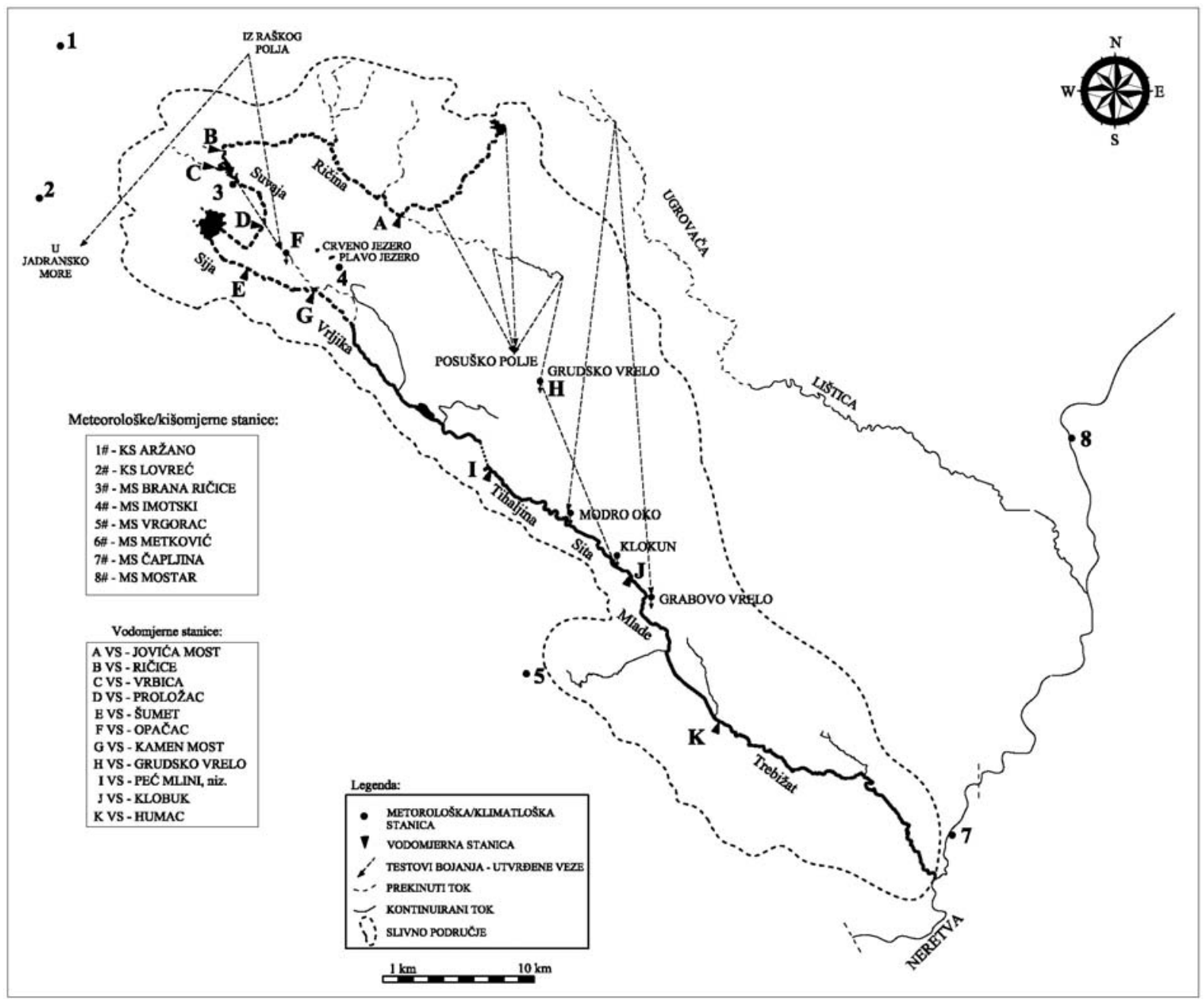

Slika 1.9. Lokacija razmatranih meteoroloških i vodomjernih stanica u slivu

Pionirska istraživanja podzemnih veza započinju sredinom prošlog stoljeća. Izvršio ih je ing. Turner 1954. (Kanaet, 1958) ispuštanjem boje u ponor Mrke stine. Nakon 59 h i 30 min traser se pojavio u Klokunu kod Klobuka a da nije utvrđen u izvorima Tihaljina, Jakšenica, i Nezdravica, koje su bliže, kao ni u Vroštici. Time je dokazana veza Tihaljine sa sistemom Vrljika - Čuluša. Vrljika dalje ponire u Šajnovcima u Bijelom polju. Daljnja bojanja Vrljke u Šajnovcima pokazala su da se voda pojavljuje u 2,5 km udaljenoj Tihaljini ali ni u jednom izvoru nizvodnu (Krupa, Bućalo). Temperaturnim mjerenjem okolnih izvora i rijeke Tihaljine ustvrdilo se da se Tihaljina obnavlja i sa vapnenačkih površina iznad izvora te da sva voda iz Vrljike ne otječe samo u Tihaljinu. Kasnija promatranja 1977. vršena od strane "Geofizike" Zagreb (Bojanić et al. 1981) potvrdila su postojanje veze između Grudskog vrila tj. njegovog najvećeg vrela Mrke stine sa vrelom u Klobuku.

Najkompleksnija istraživanja Imotskog polja i njenih fenomena izvršena su u razdoblju 1955. - 1958. (Petrik, 1960) od strane akademika Petrika koji navodi nekoliko mogućih lokacija na 
kojima bi voda koja istječe iz Crvenog jezera mogla izbiti na površinu. U obzir dolaze izvori na desnoj obali rijeke Neretve, priobalni izvori i vrulje oko Omiša, snažne i stalne vrulje koje izbijaju u uvali Vrulja između Mimica i Brela (najvjerojatnija lokacija, bez potvrđenih mjerenja), priobalni izvori i vrulje duž obale između Brela i Baške te grupe manjih od Tučepa do Drašnice.

Tijekom šezdesetih godina, točnije u razdoblju od 1964. do 1967. godine M. Komatina je usuradnji s ekipom Geološkog zavoda iz Beograda radio na izučavanju prostora sliva Trebižata, te vršio trasiranja podzemnih voda na tom području. Sedamdesetih godina su rađene osnovne geološke karte u M:1:100000. Pored istraživanja na području Ričice i Tribistova, te rijeke Tihaljine, hidrogeološka istraživanja vršili su i Ivan Slišković u suradnji sa Geološkim institutom Zagreb i Integrom Mostar tijekom 1999. - 2000. godine za potrebe gradnje HE Peć Mlini i akumulacije Nuga, kojima su dobiveni rezultati o mogućoj preraspodjeli voda Imotsko - Grudskog polja u pravcu vrela Tihaljine, nizvodnih vrela na lijevoj obali Tihaljine, kao i veze ponora duž toka Vrljike sa Rastok poljem, Jezercem i nizvodnim vrelima u donjem toku rijeke Neretve jugozapadno od doline rijeke Trebižat, kao i vruljama na morskoj obali.

1999. organizirana je međunarodna ekspedicija u Crveno jezero koja je uz važnu foto, geodetsku i video dokumentaciju ustvrdila i podzemni vodotok na dnu jezera koji se kreće put zapada ali uz još neutvrđene smjerove izviranja.

Zadnja istraživanja (Palandačić et al. 2012) uključuju i prikupljanje molekularnih baza podataka kao mogući način trasiranja tokova u krškom području. Zbog bogate endemične faune pristupilo se ideji o DNA ispitivanju riječne ribe gaovice (Delminichthys adspersus) koja se pojavljuje na raznim izvorima u promatranom slivu. Tzv. podzemni tok gena utvrđuje veze na području između Crvenog jezera i izvora Jažva, rijeka Vrgoračka i Rastočka Matica te Tihaljina i Vrljika. 


\section{METODE ANALIZE PODATAKA}

\subsection{Uvod}

Raspoloživi podaci te njihova međusobna ovisnost jedni su od važnijih komponenti kvalitetnog razvoja modela, neovisno o kakvom tipu modela se radi. Pošto i konceptualni i parametarski modeli isključivo ovise o ulaznim varijablama koje je potrebno na određeni naći transformirati u željene ciljne funkcije, provedeno je prikupljanje podataka o otjecanjima $\mathrm{i}$ klimatološkim karakteristikama na području krškog sliva smještenog na koordinatama $43^{\circ} 05^{\prime}$ i $43^{\circ} 60^{\prime}$ sjever, te $17^{\circ} 00^{\prime}$ i $17^{\circ} 60^{\prime}$ istočno. Pri tome se postavlja prva prepreka istraživanju jer se sliv nalazi na prekograničnom prostoru te nekoliko državnih i privatnih agencija prikuplja hidrološke i meteorološke podatke na rijeci sa 8 imena. Trenutno ne postoji nikakva umreženost i koordinacija među njima. Ni hidrološke ni meteorološke postaje koje će se koristiti nemaju iste početke rada, dostupne vremenske periode ni dužine osmatranja. Prikaz stanja podataka je na Slici 2.1. određen bojama - crveno označava godine za koje ne postoje nikakva zabilježena mjerenja ili djelomično dostupne podatke nije moguće nadopuniti za cijelu promatranu godinu, a zelenom bojom su označene cjelovite godine. Srednji višegodišnji prosjeci klimatskih karakteristika određuju se za razdoblje od 30 godina a zadnji period analize je 1960. - 1990. godina. Iako vremenski trenutno nije moguće zaokružiti 30-godišnje razdoblje, prikupljeni podaci za period od 1990. do danas mogu biti indikativni u smislu uočavanja klimatoloških trendova u proteklih 24 godine (2014. godina nije uzeta u obzir jer većina postaja nema obrađene podatke). 


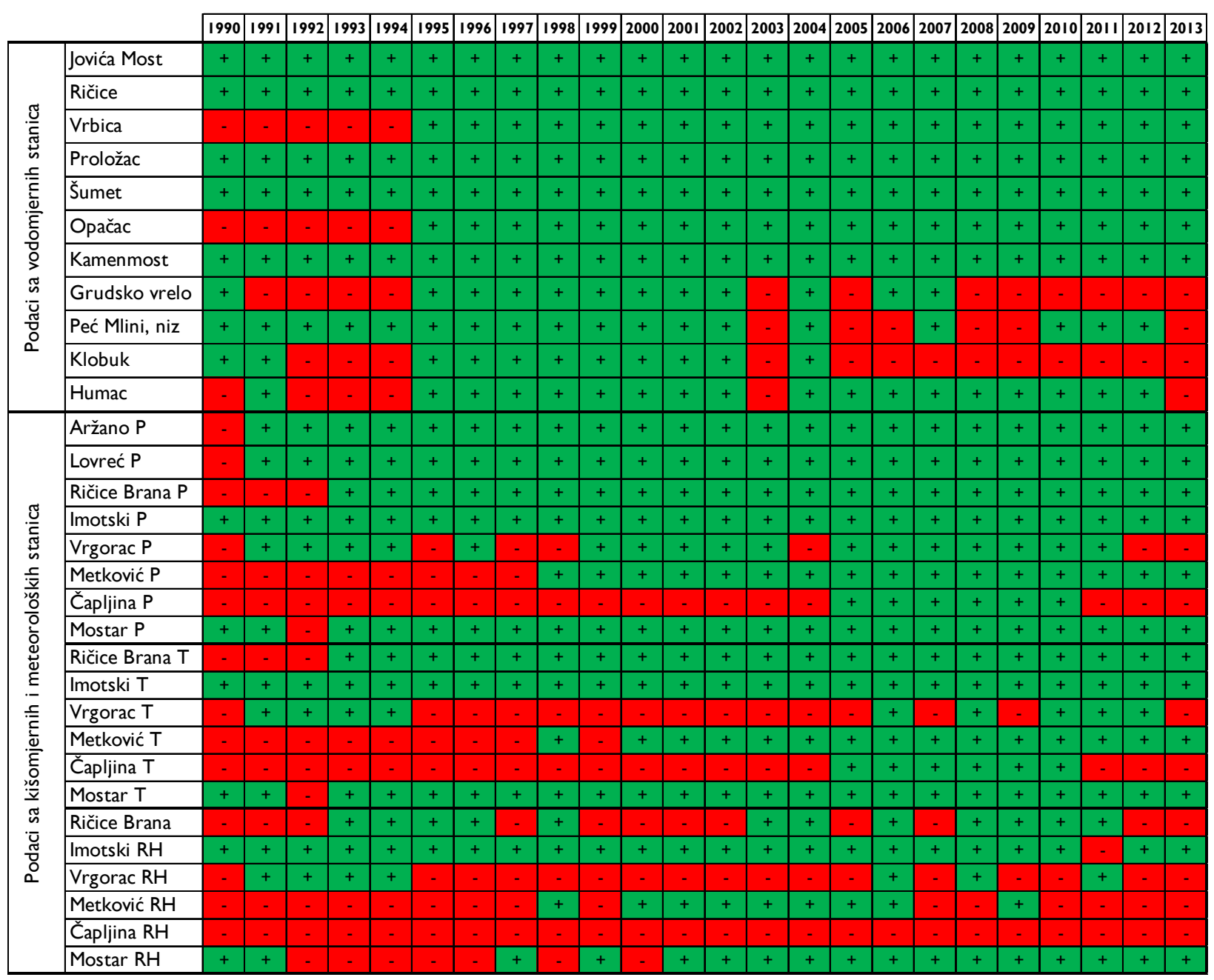

Slika 2.1. Prikaz stanja raspoloživih podataka na rijeci sa 8 imena. Oznaka T - temperature;

$$
\mathrm{RH} \text { - relativna vlažnost; } \mathrm{P} \text { - padaline }
$$

Većina postaja (meteoroloških i vodomjernih) postavljena je i održavana od strane Republičkog hidrometeorološkog zavoda Jugoslavije koji nakon 1991. više ne djeluje te nastaju Državni hidrometeorološki zavod Republike Hrvatske (DHMZ) i Federalni hidrometeorološki zavod Bosne i Hercegovine (FHMZBIH). DHMZ i FHMZBIH nastavljaju motrenje i održavanje meteoroloških (MS) i klimatoloških postaja (KS) te su time glavni izvor podataka o karakteristikama klime za istraživano područje. KS Aržano i KS Lovreć prikupljaju samo podatke o padalinama u sjevernom zaleđu sliva. Nedaleko od njih, izgradnjom rezervoara Ričice, postavljena je MS Ričice koja motri više atmosferskih pojava a za određivanje hidroloških režima koristit će se podaci o temperaturama $(\mathrm{T})$, relativnoj vlažnosti $(\mathrm{RH})$ i padalinama (P). Isti podaci prikupljeni su od još tri MS u Hrvatskoj - MS Imotski, MS Vrgorac i MS Metković. Na teritoriju BiH ne postoji ni jedna službena KS ili MS stanica koja se nalazi u samom slivu stoga će se koristi podaci sa relativno obližnjih stanica MS Čapljina i MS Mostar. 
U Hrvatskoj djeluju Hrvatske vode (HV) kao javna ustanova koja upravlja vodnim resursima Republike Hrvatske te su zaduženi za održavanje vodomjernih stanica i neovisno od DHMZ-u prikupljaju i obrađuju hidrološke podatke. U BiH je situacija nešto složenija - Agencija za vodno područje Jadranskog mora jedna je od tri postojeće javne službe za upravljanje vodnim tokovima $\mathrm{BiH}$ te kontrolira 4 vodomjerne stanice koje su od interesa za ovo istraživanje. No, izgradnjom HE Peć Mlini Elektroprivreda Hrvatske zajednice Herceg Bosne (EHZHB) preuzima kontrolu nad vodomjernim stanicama oko hidroelektrane. Sektor za hidrologiju DHMZ-a i HV ustupili su podatke sa 7 vodomjernih stanica koji će biti korišteni za utvrđivanje režima i bilance voda: VS Jovića most na Ričini, VS Ričice i VS Vrbica na pritocima u rezervoar Ričice, VS Proložac na natapnom kanalu povremenog toka Suvaje, VS Šumet na Siji te VS Opačac i VS Kamenmost na Vrljici. 2004. godine izrađena je "Hidrološka studija Trebižat Mlade Tihaljina" od strane FHMZBIH te je dio podatka od interesa prikupljen iz navedene studije a dio nadopunjen od strane EHZHB i Agencije za vodno područje Jadranskog mora. To su VS Grudsko vrelo u Imotskom polju, VS Peć Mlini nizvodno na Tihaljini (postoji i uzvodna stanica ali je stanje podataka loše), VS Klobuk na prijelazu toka iz Sita u Mlade i VS Humac na Trebižatu. Podaci koji će se obrađivati u istraživanju prikupljeni su od strane svih navedenih agencija i zavoda te je izvršena sistematizacija i pregled stanja na slivu.

\subsection{Metode obrade i selekcije podataka}

Točni odgovori na mnoga pitanja vezana za međuodnose krških formacija i hidrologije do sada se nisu opisala sa dostupnom podacima najviše zbog činjenice da od 16 meteoroloških postaja koje su postojale na području, svega ih je osam trenutno u funkciji, pet stanica imaju zabilješke o dnevnim padalinama za period dulji od 10 godina. Postaje nisu ravnomjerno raspoređene - oko $50 \%$ područja je prekriveno postajama (Slika 2.2.) ukoliko se uzme u obzir preporuka WMO (World Meteorological Organization) o gustoći meteorološke mreže u planinskim predjelima (WMO, 2008). Situacija sa vodomjernim stanicama je slična - 35 postaja je instalirano u razdoblju od 1924. (postavljena stanica Kamenmost) do danas, od kojih je 11 uzeto u obzir za daljnje razmatranje jer imaju (donekle) kontinuirano praćenje. 


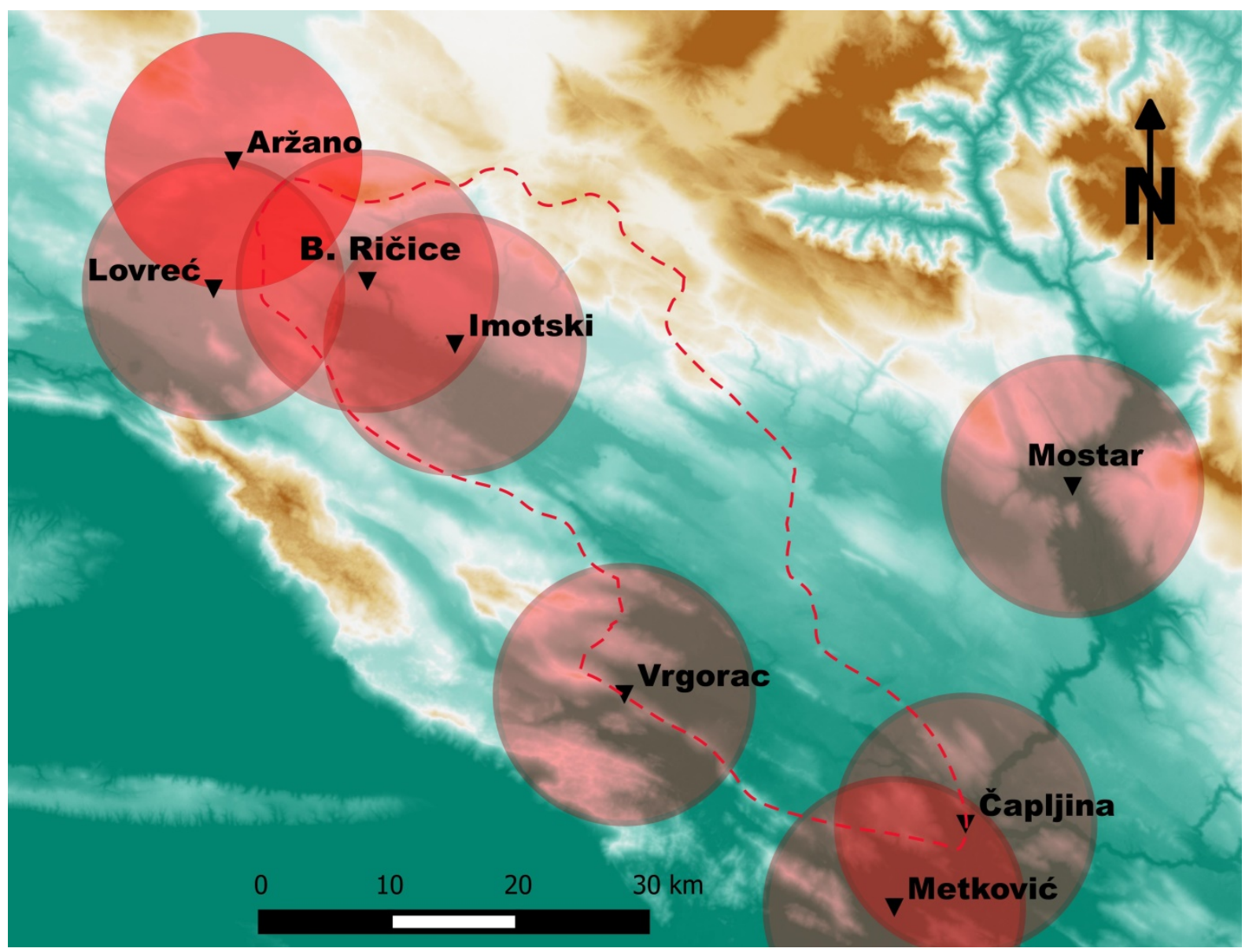

Slika 2.2. Smještaj meteoroloških i klimatoloških postaja na slivu

Kumulativna godišnja oborina prikazana je u Tablici 2.1. te je prosječna količina za razdoblje od 1990. do 2014. $1341 \mathrm{~mm}$, sa najmanjim prosjekom za postaju Čapljina od $1159 \mathrm{~mm}$, s tim da se ova vrijednost uzima sa rezervom, pošto se radi o postaji sa samo 6 godina zabilježenih padalina. Najveća prosječna oborina registrirana je na postaji Vrgorac kao i maksimalna godišnja količina oborine- $3131 \mathrm{~mm}$. Zanimljivo je primijetiti da je 2010. godina najkišovitija za sve promatrane postaje (prosječno $2130 \mathrm{~mm}$ ) a slijedi je najsuša 2011. godina sa prosjekom od $928 \mathrm{~mm} \mathrm{i}$ najnižom količinom od $791 \mathrm{~mm}$ na postaji Imotski kada je i zabilježeno presušivanje Modrog jezera koje je trajalo više od 90 dana.

Tablica 2.1. Ukupna godišnja oborina za razdoblje 1990. - 2014. 
Ukupne oborine $(\mathrm{mm} / \mathrm{god})$

Aržano Lovreć B. Ričice Imotski Vrgorac Met

\begin{tabular}{|c|c|c|c|c|c|c|c|c|c|}
\hline & ržano & Lovreć & B. Ričice & Imotski & Vrgorac & Metković & Čapljina & Mostar & $A V R$ \\
\hline 1990 & - & - & - & 920 & - & - & - & 1185 & 1053 \\
\hline 1991 & 1372 & 1339 & - & 1433 & 1458 & - & - & 1450 & 1410 \\
\hline 1992 & 993 & 1052 & - & 911 & 1323 & - & - & - & 1070 \\
\hline 1993 & 1057 & 1178 & 1248 & 1154 & 1416 & - & - & 1150 & 1200 \\
\hline 1994 & 941 & 1012 & 1134 & 925 & 1405 & - & - & 897 & 1052 \\
\hline 1995 & 1353 & 1362 & 1763 & 1556 & - & - & - & 1592 & 1525 \\
\hline 1996 & 1318 & 1495 & 1800 & 1493 & 2010 & - & - & 1973 & 1681 \\
\hline 1997 & 1034 & 831 & 1209 & 1031 & - & - & - & 1199 & 1061 \\
\hline 1998 & 1258 & 1078 & 1221 & 1022 & - & 1138 & - & 1458 & 1196 \\
\hline 1999 & 1726 & 1416 & 1705 & 1484 & 2014 & 1422 & - & 1776 & 1649 \\
\hline 2000 & 1246 & 1048 & 1249 & 1090 & 1509 & 1030 & - & 1206 & 1197 \\
\hline 2001 & 1152 & 1135 & 1118 & 1108 & 1560 & 987 & - & 1232 & 1184 \\
\hline 2002 & 1375 & 1328 & 1282 & 1280 & 1859 & 968 & - & 1395 & 1355 \\
\hline 2003 & 1183 & 1062 & 1087 & 989 & 1534 & 817 & - & 1162 & 1119 \\
\hline 2004 & 1728 & 1430 & 1715 & 1522 & - & 1415 & - & 1714 & 1587 \\
\hline 2005 & 1371 & 1317 & 1274 & 1321 & 2040 & 1352 & 1315 & 1586 & 1447 \\
\hline 2006 & 1040 & 827 & 885 & 962 & 1566 & 1023 & 929 & 1044 & 1034 \\
\hline 2007 & 1196 & 1016 & 1056 & 1059 & 1511 & 1045 & 1078 & 1240 & 1150 \\
\hline 2008 & 1547 & 1327 & 1616 & 1395 & 2091 & 1296 & 1053 & 1430 & 1469 \\
\hline 2009 & 1536 & 1331 & 1557 & 1515 & 2269 & 1555 & 1023 & 1849 & 1579 \\
\hline 2010 & 2002 & 1880 & 2093 & 1907 & 3131 & 1981 & 1556 & 2491 & 2130 \\
\hline 2011 & 918 & 904 & 890 & 791 & 1326 & 793 & - & 873 & 928 \\
\hline 2012 & 1180 & 984 & 1203 & 1102 & - & 1141 & - & 1395 & 1168 \\
\hline 2013 & 1625 & 1535 & 1654 & 1658 & - & 1623 & - & 2188 & 1714 \\
\hline$A V R$ & 1311 & 1212 & 1370 & 1234 & 1766 & 1224 & 1159 & 1456 & 1341 \\
\hline
\end{tabular}

Korišten je koeficijent korelacije $\mathrm{R}^{2}$ prema Pearsonu:

$$
R^{2}=\frac{\sum_{i=1}^{n}\left(x_{i}-\bar{x}\right)\left(y_{i}-\bar{y}\right)}{\sqrt{\sum_{i=1}^{n}\left(x_{i}-\bar{x}\right)^{2} \sum_{i=1}^{n}\left(y_{i}-\bar{y}\right)^{2}}}
$$

gdje su $x_{i}$ i $y_{i}$ promatrane varijable a $\bar{x}$ i $\bar{y}$ srednje vrijednosti skupa, za evaluaciju jakost linearne veze među stanicama na dnevnoj, mjesečnoj i godišnjoj razini. Očekivano, ovakve veze su najslabije na dnevnoj razini $\left(\mathrm{R}^{2}<0.7\right.$; Tablica 2.2.) i to kod međusobno najudaljenijih stanica. Linearna veza jača na mjesečnoj (Tablica 2.3.) i ponajviše na godišnjoj (Tablica 2.4.) razini ali je utjecaj nedostajućih podataka vidljiv - MS Čapljina koja je $8.5 \mathrm{~km}$ udaljena od MS Metković na godišnjoj razini pokazuje veću korelaciju sa KS Lovreć $\left(\mathrm{R}^{2}=0.85\right)$ nego sa sebi najbližom stanicom $\left(\mathrm{R}^{2}=0.78\right)$. Godišnje korelacije su općenito zadovoljavajuće $\left(\mathrm{R}_{\text {min }}^{2}>0.7\right)$ i time daju mogućnost osrednjavanja prikupljenih podataka u svrhu pojednostavljenja ulaznih podataka za konceptualni i parametarski model.

Tablica 2.2. Koeficijent korelacije dnevnih količina oborina 


\begin{tabular}{r|cccccccc} 
& Aržano & Lovreć & B. Ričice & Imotski & Vrgorac & Metković & Čapljina & Mostar \\
\hline Aržano & 1 & 0.8523 & 0.8148 & 0.7699 & 0.7200 & 0.5771 & 0.5496 & 0.6704 \\
Lovreć & - & 1 & 0.8488 & 0.8057 & 0.7083 & 0.6130 & 0.5862 & 0.6723 \\
B. Ričice & - & - & 1 & 0.8649 & 0.7683 & 0.6345 & 0.6144 & 0.6986 \\
Imotski & - & - & - & 1 & 0.7457 & 0.6694 & 0.6244 & 0.7176 \\
Vrgorac & - & - & - & - & 1 & 0.7249 & 0.6695 & 0.7580 \\
Metković & - & - & - & - & - & 1 & 0.7262 & 0.7415 \\
Čapljina & - & - & - & - & - & - & 1 & 0.8086 \\
Mostar & - & - & - & - & - & - & - & 1
\end{tabular}

Tablica 2.3. Koeficijent korelacije mjesečnih količina oborina

\begin{tabular}{r|cccccccc} 
& Aržano & Lovreć & B. Ričice & Imotski & Vrgorac & Metković & Čapljina & Mostar \\
\hline Aržano & 1 & 0.9326 & 0.9033 & 0.9176 & 0.8467 & 0.7624 & 0.7227 & 0.8325 \\
Lovreć & - & 1 & 0.9092 & 0.9229 & 0.8428 & 0.7895 & 0.7576 & 0.8422 \\
B. Ričice & - & - & 1 & 0.9472 & 0.8809 & 0.8061 & 0.7843 & 0.8583 \\
Imotski & - & - & - & 1 & 0.8913 & 0.8491 & 0.7625 & 0.8780 \\
Vrgorac & - & - & - & - & 1 & 0.8815 & 0.8028 & 0.8943 \\
Metković & - & - & - & - & - & 1 & 0.8380 & 0.8644 \\
Čapljina & - & - & - & - & - & - & 1 & 0.8808 \\
Mostar & - & - & - & - & - & - & - & 1
\end{tabular}

Tablica 2.4. Koeficijent korelacije godišnjih količina oborina

\begin{tabular}{r|cccccccc} 
& Aržano & Lovreć & B. Ričice & Imotski & Vrgorac & Metković & Čapljina & Mostar \\
\hline Aržano & 1 & 0.8832 & 0.8632 & 0.9114 & 0.9010 & 0.8996 & 0.7684 & 0.8835 \\
Lovreć & - & 1 & 0.9125 & 0.9406 & 0.8680 & 0.8746 & 0.8578 & 0.8983 \\
B. Ričice & - & - & 1 & 0.9497 & 0.8726 & 0.9050 & 0.7045 & 0.8877 \\
Imotski & - & - & - & 1 & 0.8868 & 0.9415 & 0.7651 & 0.9264 \\
Vrgorac & - & - & - & - & 1 & 0.9527 & 0.8015 & 0.9172 \\
Metković & - & - & - & - & - & 1 & 0.7889 & 0.9603 \\
Čapljina & - & - & - & - & - & - & 1 & 0.8224 \\
Mostar & - & - & - & - & - & - & - & 1
\end{tabular}

Osim padalina, moguće je analizirati i kretanje temperatura i relativne vlažnosti na šest MS-ova u području. Vidljivo je (Tablica 2.5.) da srednja godišnja temperatura kreće u rasponu od $13^{\circ} \mathrm{C}$ na sjevernom dijelu sliva (MS B. Ričice) do $15^{\circ} \mathrm{C}$ na južnom (MS Čapljina) gdje se bilježe $\mathrm{i}$ najveće maksimalne dnevne temperature.

Tablica 2.5. Prikaz srednjih godišnjih temperatura te maksimalnih i minimalnih dnevnih temperatura suhog termometra 


\begin{tabular}{|c|c|c|c|c|c|c|c|c|c|c|c|c|c|c|c|c|c|c|}
\hline & \multicolumn{3}{|c|}{ Ričice Brana } & \multicolumn{3}{|c|}{ Imotski } & \multicolumn{3}{|c|}{ Vrgorac } & \multicolumn{3}{|c|}{ Metković } & \multicolumn{3}{|c|}{ Čapljina } & \multicolumn{3}{|c|}{ Mostar } \\
\hline & AVR & MIN & MAX & AVR & MIN & MAX & AVR & MIN & MAX & AVR & MIN & MAX & AVR & MIN & MAX & AVR & MIN & MAX \\
\hline 990 & - & - & - & 14.1 & 0.6 & 28.4 & - & - & - & - & - & - & - & - & - & 15.6 & 0.6 & 30.9 \\
\hline 1991 & - & - & - & 13.1 & -5.8 & 28.4 & 13.1 & -4.4 & 28.0 & 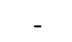 & - & - & - & - & - & 14.7 & -3.4 & 30.4 \\
\hline 1992 & - & - & - & 14.2 & -2.9 & 29.5 & 14.2 & -1.1 & 29.6 & - & - & - & - & - & - & - & - & - \\
\hline 1993 & 13.0 & -5.8 & 27.8 & 14.1 & -4.8 & 29.5 & 14.3 & -2.4 & 29.1 & - & - & - & - & - & - & 15.2 & -2.7 & 32.6 \\
\hline 1994 & 13.8 & -3.6 & 28.0 & 14.8 & -5.3 & 29.3 & 15.0 & -1.8 & 29.4 & - & - & - & - & - & - & 16.3 & -2.4 & 30.8 \\
\hline 1995 & 12.2 & -1.4 & 27.0 & 13.2 & 0.1 & 29.0 & - & - & - & - & - & - & - & - & - & 14.6 & 1.5 & 30.3 \\
\hline 1996 & 12.1 & -6.8 & 26.0 & 13.3 & -5.6 & 28.2 & - & - & - & - & - & - & - & - & - & 14.6 & -4.4 & 30.5 \\
\hline 1997 & 12.8 & 0.6 & 25.8 & 13.9 & 2.8 & 25.8 & - & - & - & - & - & - & - & - & - & 15.1 & 2.5 & 28.7 \\
\hline 1998 & 12.8 & -2.5 & 30.5 & 14.0 & -1.7 & 31.8 & - & - & - & 14.8 & -0.2 & 29.7 & - & - & - & 15.2 & -0.3 & 33.0 \\
\hline 1999 & 12.9 & -6.0 & 28.3 & 14.2 & -5.2 & 30.2 & - & - & - & - & - & - & - & - & - & 15.4 & -2.5 & 31.4 \\
\hline 2000 & 13.8 & -7.7 & 30.1 & 14.9 & -5.0 & 32.4 & - & - & - & 15.3 & -3.5 & 30.1 & - & - & - & 16.0 & -4.3 & 32.4 \\
\hline 2001 & 13.1 & -5.3 & 28.4 & 14.1 & -4.2 & 30.3 & - & - & - & 15.2 & -2.0 & 29.3 & - & - & - & 15.5 & -2.4 & 31.7 \\
\hline 2002 & 13.3 & -4.8 & 28.0 & 14.3 & -4.1 & 29.9 & - & - & - & 15.4 & -1.6 & 29.6 & - & - & - & 15.8 & -2.2 & 30.9 \\
\hline 2003 & 13.5 & -3.0 & 28.8 & 14.7 & -2.0 & 30.4 & - & - & - & 15.7 & 0.8 & 30.7 & - & - & - & 16.2 & -0.8 & 31.9 \\
\hline 2004 & 12.6 & -6.3 & 28.2 & 13.8 & -5.2 & 29.6 & - & - & - & 15.1 & -2.0 & 30.1 & - & - & - & 15.2 & -2.6 & 32.2 \\
\hline 2005 & 12.1 & -6.6 & 29.2 & 13.2 & -5.9 & 30.9 & - & - & - & 14.2 & -1.8 & 29.2 & 14.8 & -2.4 & 31.6 & 14.6 & -2.7 & 31.3 \\
\hline 2006 & 12.5 & -5.0 & 28.4 & 13.8 & -4.9 & 30.9 & 14.7 & -1.6 & 31.2 & 14.7 & -0.8 & 29.8 & $\mid 15.4$ & -1.5 & 31.7 & 15.3 & -3.8 & 32.6 \\
\hline 2007 & 13.6 & -2.4 & 32.2 & 14.7 & -1.7 & 31.7 & - & - & - & 15.6 & 0.8 & 32.1 & \begin{tabular}{|l|l}
16.4 \\
\end{tabular} & 1.2 & 33.9 & 16.1 & 0.5 & 32.9 \\
\hline 2008 & 13.3 & -4.5 & 27.9 & 14.6 & -3.1 & 29.6 & 16.0 & -1.5 & 30.8 & 15.9 & -1.0 & 32.3 & \begin{tabular}{|l|l}
16.4 \\
\end{tabular} & -1.1 & 31.3 & 16.1 & -0.6 & 31.1 \\
\hline 2009 & 13.2 & -6.7 & 28.3 & 14.3 & -5.3 & 29.2 & - & - & - & 15.6 & -1.2 & 30.4 & 16.2 & -1.2 & 30.9 & 15.8 & -3.3 & 31.5 \\
\hline 2010 & 12.7 & -4.3 & 27.8 & 13.7 & -4.3 & 30.2 & 14.9 & -1.7 & 31.5 & 15.2 & -2.4 & 29.9 & 15.7 & -1.0 & 31.2 & 15.2 & -0.9 & 31.8 \\
\hline 2011 & 13.8 & -2.2 & 29.5 & 15.0 & -0.5 & 30.3 & 16.2 & 0.6 & 32.4 & 15.8 & 1.0 & 29.9 & - & - & - & 16.2 & 0.8 & 32.4 \\
\hline 2012 & 13.5 & -7.4 & 29.4 & 14.9 & -5.9 & 31.1 & 16.3 & -3.0 & 32.7 & 15.6 & -2.6 & 30.0 & - & - & - & 16.2 & -5.8 & 33.3 \\
\hline 2013 & 13.7 & -1.3 & 29.7 & 14.8 & -0.8 & 31.4 & - & - & - & 15.9 & 1.5 & 29.5 & - & - & - & 15.9 & 2.3 & 32.7 \\
\hline$A V R$ & 13.1 & -4.4 & 28.5 & 14.2 & -3.4 & 29.9 & 15.0 & -1.9 & 30.5 & 15.3 & -1.0 & 30.2 & 15.8 & -1.0 & 31.8 & 15.5 & -1.6 & 31.6 \\
\hline
\end{tabular}

Dnevne i mjesečne korelacije srednjih dnevnih temperatura pokazuju značajnu vezu jer su izračunate vrijednosti redom veće od $\mathrm{R}^{2}=0.9$, dok godišnje ponovno ukazuju na problem malog uzorka koji se promatra (Tablica 2.6.) - MS Vrgorac i MS B. Ričice su najmanje korelirane ( ${ }^{2}$ $=0.63$ ) na temelju 7 promatranih godina, a MS Vrgorac i MS Čapljina moguće je usporediti je sa samo 3 zajedničke registrirane godine $\left(\mathrm{R}^{2}=0.99\right)$.

Tablica 2.6. Koeficijent korelacije srednje godišnje temperature

\begin{tabular}{l|cccccc} 
& B. Ričice & Imotski & Vrgorac & Metković & Čapljina & Mostar \\
\hline B. Ričice & 1 & 0.9780 & 0.6382 & 0.8697 & 0.9893 & 0.9555 \\
Imotski & - & 1 & 0.8484 & 0.8536 & 0.9677 & 0.9634 \\
Vrgorac & - & - & 1 & 0.9016 & 0.9902 & 0.8772 \\
Metković & - & - & - & 1 & 0.9846 & 0.7469 \\
Čapljina & - & - & - & - & 1 & 0.9779 \\
Mostar & - & - & - & - & - & 1
\end{tabular}

Najlošije stanje podataka uočava se kod podataka o srednjoj relativnoj vlažnosti (RH) pošto je od 144 (24 godine i 6 stanica) mogućih nizova ulaznih podataka dostupno njih 47\%. MS Čapljina ne bilježi niti jednu cjelovitu godinu a ostale stanice imaj barem jednu koja nedostaje. Godišnje korelacije kreću se od -0.93 do 0.82 i nisu pouzdane. Ukoliko se vremenski korak 
smanji, odnosi su nešto bolji - mjesečna korelacija je u rasponu $0.52-0.84$, a dnevna $0.54-$ 0.74. Srednja relativna vlažnost će se stoga promatrati kao jedinstvena za sve stanice i osrednjena na temelju podataka sa MS B. Ričice, MS Imotski i MS Vrgorac jer (Slika 2.3.) MS Mostar odskače od srednjih mjesečnih vrijednosti RH.

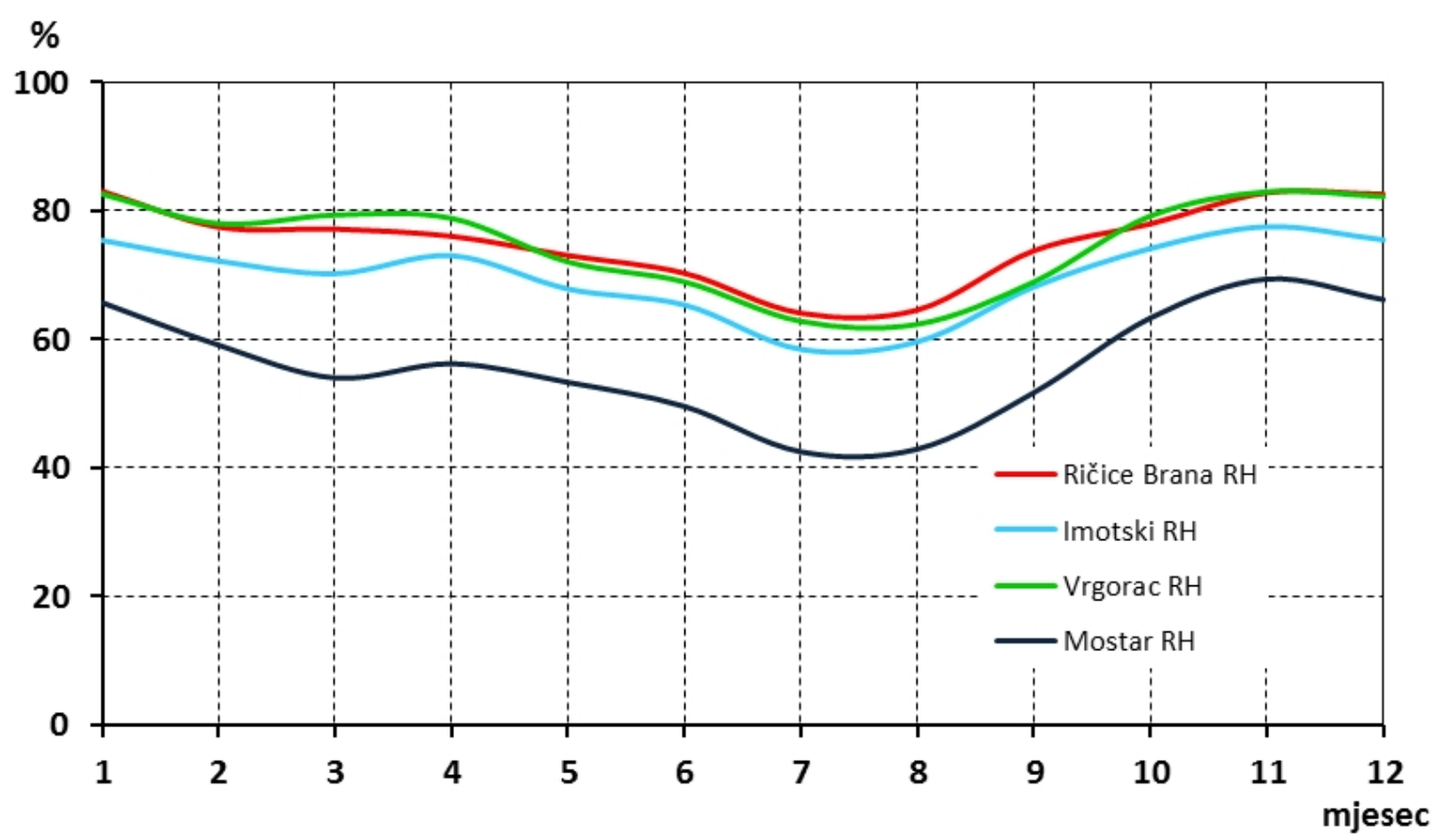

Slika 2.3. Prosječne mjesečne vrijednosti relativne vlažnosti $(\mathrm{RH})$ po mjesecima

Tablica 2.7. pokazuje promjenu srednjih godišnjih protoka, minimalne i maksimalne protoke na stanicama koje će se razmatrati u istraživanju. Pošto su za određene VS dostupni podaci prije 1990. godine, napravljena je analiza 3 razdoblja u trajanju od 12 godina i to za periode: 1978. 1989., 1990. - 2001. i 2002. - 2013. Analiza nije rađena za postaje gdje nedostaje više od 50\% godina u navedena 3 perioda, a ukoliko nedostaje $10-40 \%$ podataka isti su prikazani u kurzivu. Primjećuje se da su srednje godišnje protoke relativno stabilne kroz sva tri razdoblja iako VS Humac pokazuje značajniji pad vrijednosti kao i kod minimalnih protoka gdje 2012. prvi put i presušuje. Očito je da uzvodniji dijelovi (od VS Jovića most do VS Šumet) redovito presušuju kao i VS Grudsko vrelo koje ne pripada samom toku ali je značajno za utvrđivanja zajedničkog funkcioniranja sliva, kako nadzemnog tako i podzemnog. Maksimalne protoke redom bilježe pad u 2. periodu razmatranja te ili lagani porast u 3. periodu ili daljnji pad vrijednosti. Najveće promjene maksimalnih protoka imaju VS Proložac i VS Šumet te se one mogu pripisati antropogenom utjecaju u vidu izgradnje akumulacije Ričice što pokazuju i prethodna istraživanja (Bonacci i Roje-Bonacci, 2000) gdje je utvrđeno da je prije izgradnje, prosječni protok 
otvorenog vodotoka Suvaje na VS Proložac iznosio oko $1 \mathrm{~m}^{3} / \mathrm{s}$, a korito je bilo suho oko 100 dana godišnje. Nakon izgradnje akumulacije Ričice, prosječni protok pada na oko 40 1/s, a vodotok presušuje 200 dana godišnje. Zaključuju da je moguće da je nakon izgradnje brane i akumulacije Ričice voda preusmjerena prema četiri izvora rijeke Vrljike koji nikad ne presušuju.

Tablica 2.7. Karakteristični (prosječni, minimalni i maksimalni) protoci utvrđeni na rijeci sa 8 imena

\begin{tabular}{ll|ccc|ccc|ccc}
\multicolumn{1}{c|}{ VS } & Vodotok & \multicolumn{2}{c|}{$\mathbf{Q}_{\text {avr }}\left(\mathbf{m}^{\mathbf{3}} / \mathbf{s}\right)$ za periode: } & \multicolumn{2}{c|}{$\mathbf{Q}_{\min }\left(\mathbf{m}^{\mathbf{3}} / \mathbf{s}\right)$ za periode: } & \multicolumn{2}{c}{$\mathbf{Q}_{\max }\left(\mathbf{m}^{\mathbf{3}} / \mathbf{s}\right)$ za periode: } \\
& & $\mathbf{7 8 - 8 9}$ & $\mathbf{9 0 - 0 1}$ & $\mathbf{0 2 - 1 3}$ & $\mathbf{7 8 - 8 9}$ & $\mathbf{9 0 - 0 1}$ & $\mathbf{0 2 - 1 3}$ & $\mathbf{7 8 - 8 9}$ & $\mathbf{9 0 - 0 1}$ & $\mathbf{0 2 - 1 3}$ \\
\hline Jovića Most & Ričina & 0.24 & 0.10 & 0.10 & 0.00 & 0.00 & 0.00 & 37.20 & 37.80 & 32.50 \\
Ričice & Ričina & - & 0.28 & 0.29 & - & 0.00 & 0.00 & - & 34.70 & 43.90 \\
Vrbica & Ričina & - & 0.07 & 0.08 & - & 0.00 & 0.00 & - & 1.72 & 2.32 \\
Proložac & Suvaja & 0.74 & 0.07 & 0.08 & 0.00 & 0.00 & 0.00 & 82.10 & 31.70 & 11.00 \\
Šumet & Sija & 1.28 & 0.44 & 0.62 & 0.00 & 0.00 & 0.00 & 45.90 & 11.60 & 9.08 \\
Opačac & Vrljika & - & 6.61 & 6.71 & - & 1.03 & 0.56 & - & 49.90 & 44.80 \\
Kamenmost & Vrljika & 9.08 & 6.91 & 7.93 & 0.57 & 0.46 & 0.50 & 79.80 & 56.80 & 61.50 \\
Grudsko vr. & - & 2.46 & 2.74 & 2.89 & 0.00 & 0.00 & 0.00 & 10.98 & 13.70 & 9.47 \\
Peć Mlini niz. & Tihaljina & 11.45 & 9.46 & 11.42 & 0.12 & 0.12 & 0.42 & 64.00 & 65.00 & 70.46 \\
Klobuk & Mlade & 26.18 & 20.60 & 18.87 & 3.03 & 2.26 & 2.96 & 171.24 & 148.37 & 109.00 \\
Humac & Trebižat & 30.19 & 25.80 & 29.25 & 1.21 & 1.49 & 0.00 & 168.18 & 155.75 & 158.10
\end{tabular}

\subsubsection{Linearna regresija}

Nakon osnovne obrade podataka bitno je utvrditi odnose funkcije cilja - protoke prema varijablama koje su od posebnog značaja a to su prvenstveno registrirane oborine. Potrebno je odrediti utjecaj pojedine KS stanice na VS stanice tj. koja registrirana padalina najviše utječe na izmjereni protok. Sužavanje izbora takvih utjecajnih stanica može se prikazati Thiessenovim poligonima, no ova metoda daje smislene rezultate ukoliko se poligoni konstruiraju unutar granica sliva. U slučaju rijeke sa 8 imena samo se dvije stanice (Ričice i Imotski) nalaze unutar slivnog područja. Stoga se Thiessenova metoda primjena i na vodomjernim i na kišomjernim stanicama na površini od $5300 \mathrm{~km}^{2}$ koja time zahvaća sve razmatrane postaje (Slika 2.4.). Nakon konstrukcije poligona izmjeren je udio pojedinog poligona KS stanice unutar VS stanice (Tablica 2.8.). Zanimljivo je primijetiti da MS Mostar nema nikakvog utjecaja prema izvršenoj konstrukciji poligona. 


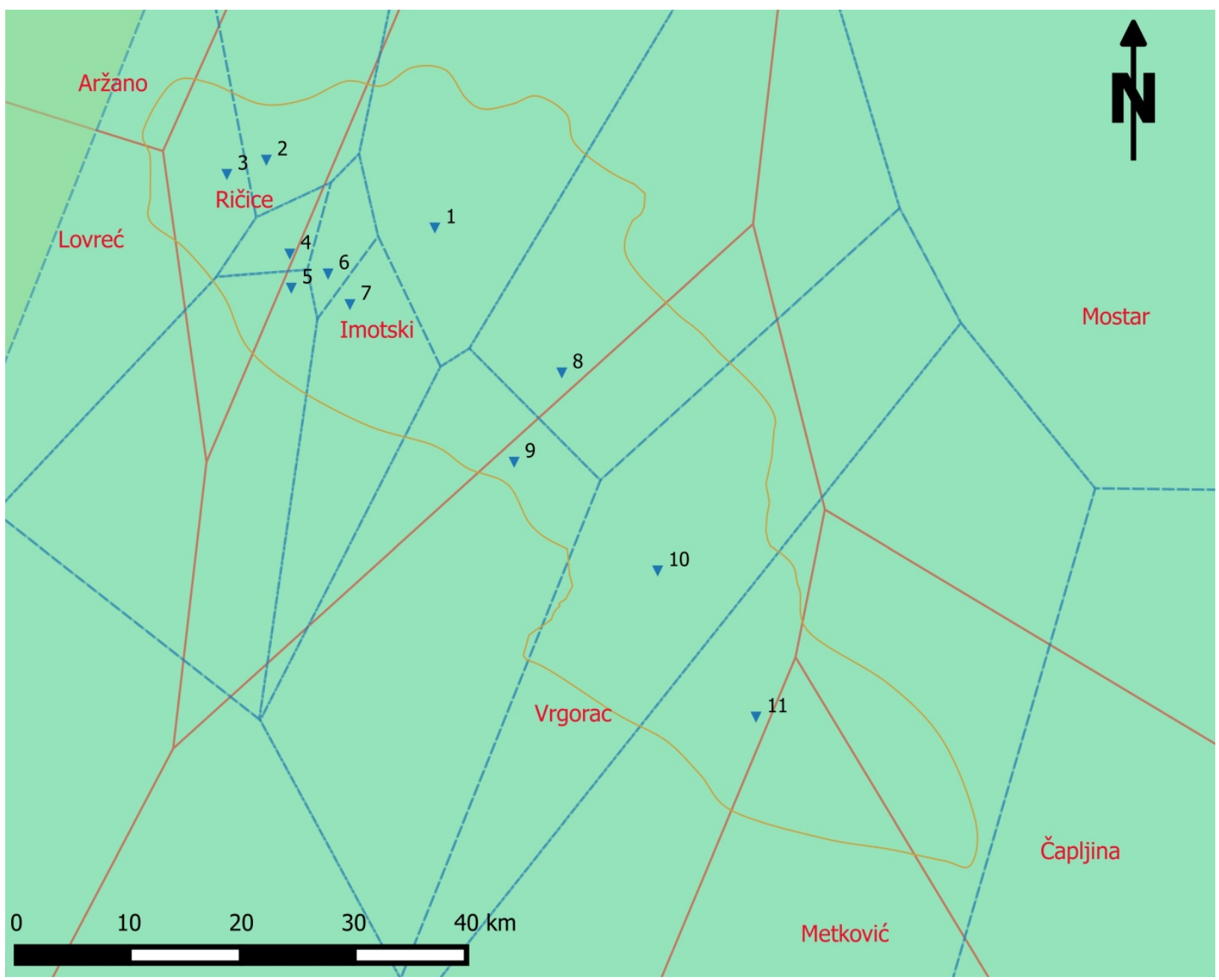

Slika 2.4. Konstruirani Thiessenovi poligoni nad slivom. Brojkama su označene VS stanice: 1 Jovica most; 2 - Ričina; 3 - Vrbica; 4 - Proložac; 5 - Šumet; 6 - Opačac; 7 - Kamenmost; 8 Grudsko vrelo; 9 - Peć Mlini niz; 10 - Klobuk; 11 - Humac. Crvene linije predstavljaju KS poligone, plave linije VS poligone a žuta je granica sliva.

Tablica 2.8. Proračun utjecaja KS na VS

\begin{tabular}{|c|c|c|c|c|c|c|c|c|c|}
\hline \multirow[b]{2}{*}{ Ime VS } & \multirow[b]{2}{*}{ Površina $\left(\mathrm{km}^{2}\right)$} & \multicolumn{8}{|c|}{ utjecaj KS na VS (\%) } \\
\hline & & Aržano & Lovreć & Ričice & Imotski & Vrgorac & Metković & Čapljina & Mostar \\
\hline Jovica most & 196 & - & - & - & $100 \%$ & - & - & - & - \\
\hline Ričina & 57 & - & - & $89 \%$ & $11 \%$ & - & - & - & - \\
\hline Vrbica & 75 & $12 \%$ & $9 \%$ & $79 \%$ & - & - & - & - & - \\
\hline Proložac & 27 & - & - & $78 \%$ & $22 \%$ & - & - & - & - \\
\hline Šumet & 39 & - & - & $38 \%$ & $62 \%$ & - & - & - & - \\
\hline Opačac & 29 & - & - & - & $100 \%$ & - & - & - & - \\
\hline Kamenmost & 77 & - & - & - & $100 \%$ & - & - & - & - \\
\hline Grudsko vrelo & 200 & - & - & - & $64 \%$ & $37 \%$ & - & - & - \\
\hline Peć Mlini niz & 83 & - & - & - & $54 \%$ & $46 \%$ & - & - & - \\
\hline Klobuk & 239 & - & - & - & - & $100 \%$ & - & - & - \\
\hline Humac & 255 & - & - & - & - & $36 \%$ & $31 \%$ & $33 \%$ & - \\
\hline SUM: & 1277 & & & & & & & & \\
\hline
\end{tabular}


Dobiveni rezultati (Tablica 2.8.) su indikatori za utvrđivanje veza među linearnim regresijskim pravcima jer se sužava broj P-Q (padaline - oborina) parova. Godišnje kumulativne oborine u odnosu na prosječne protoke prikazane su na Slici 2.5. - 2.15.

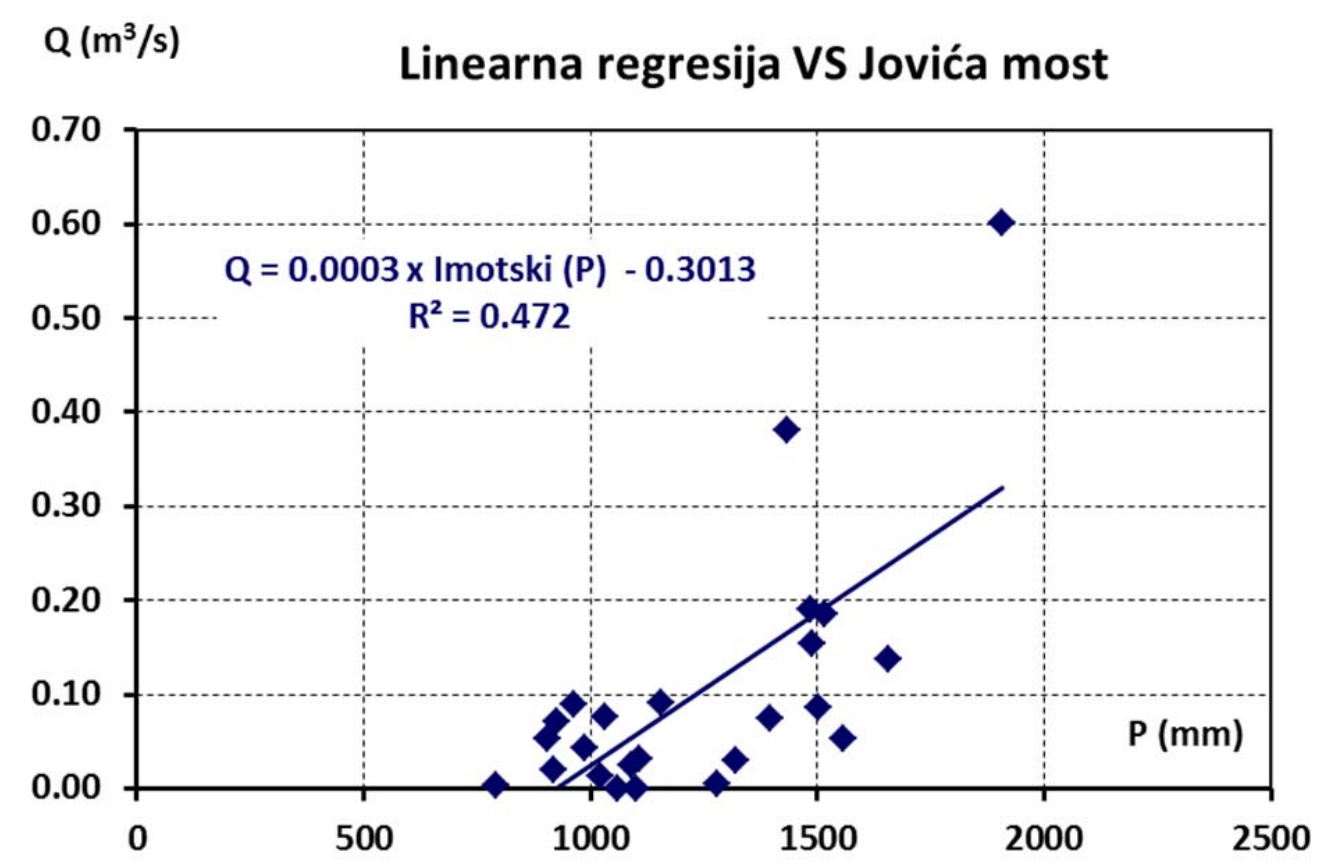

Slika 2.5. Odnosi srednjih godišnjih protoka $Q\left(\mathrm{~m}^{3} / \mathrm{s}\right)$ i ukupnih godišnjih padalina $\mathrm{P}(\mathrm{mm}) \mathrm{za}$ VS Jovića most

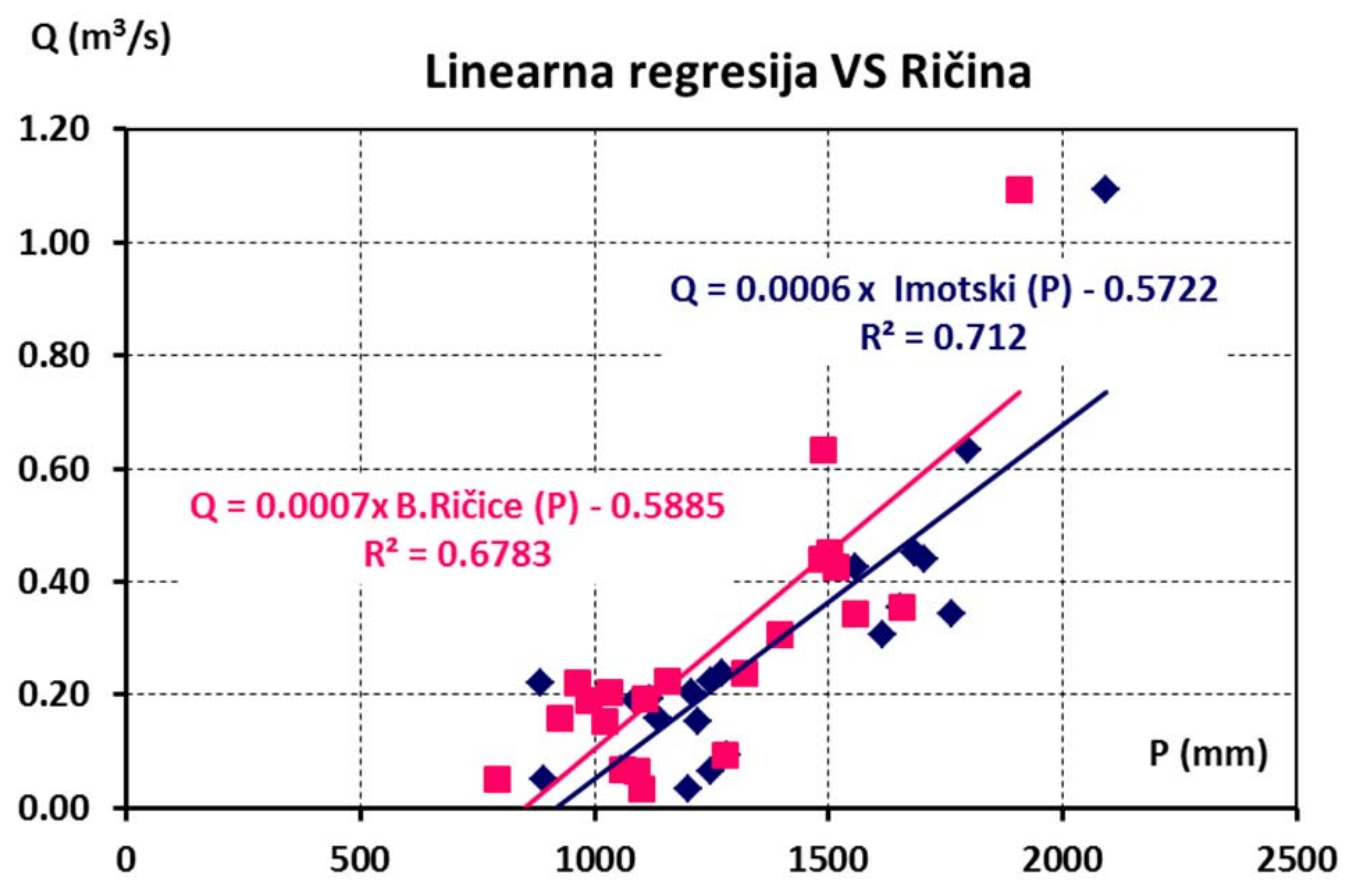

Slika 2.6. Odnosi srednjih godišnjih protoka $Q\left(\mathrm{~m}^{3} / \mathrm{s}\right)$ i ukupnih godišnjih padalina $\mathrm{P}(\mathrm{mm}) \mathrm{za}$ VS Ričina 


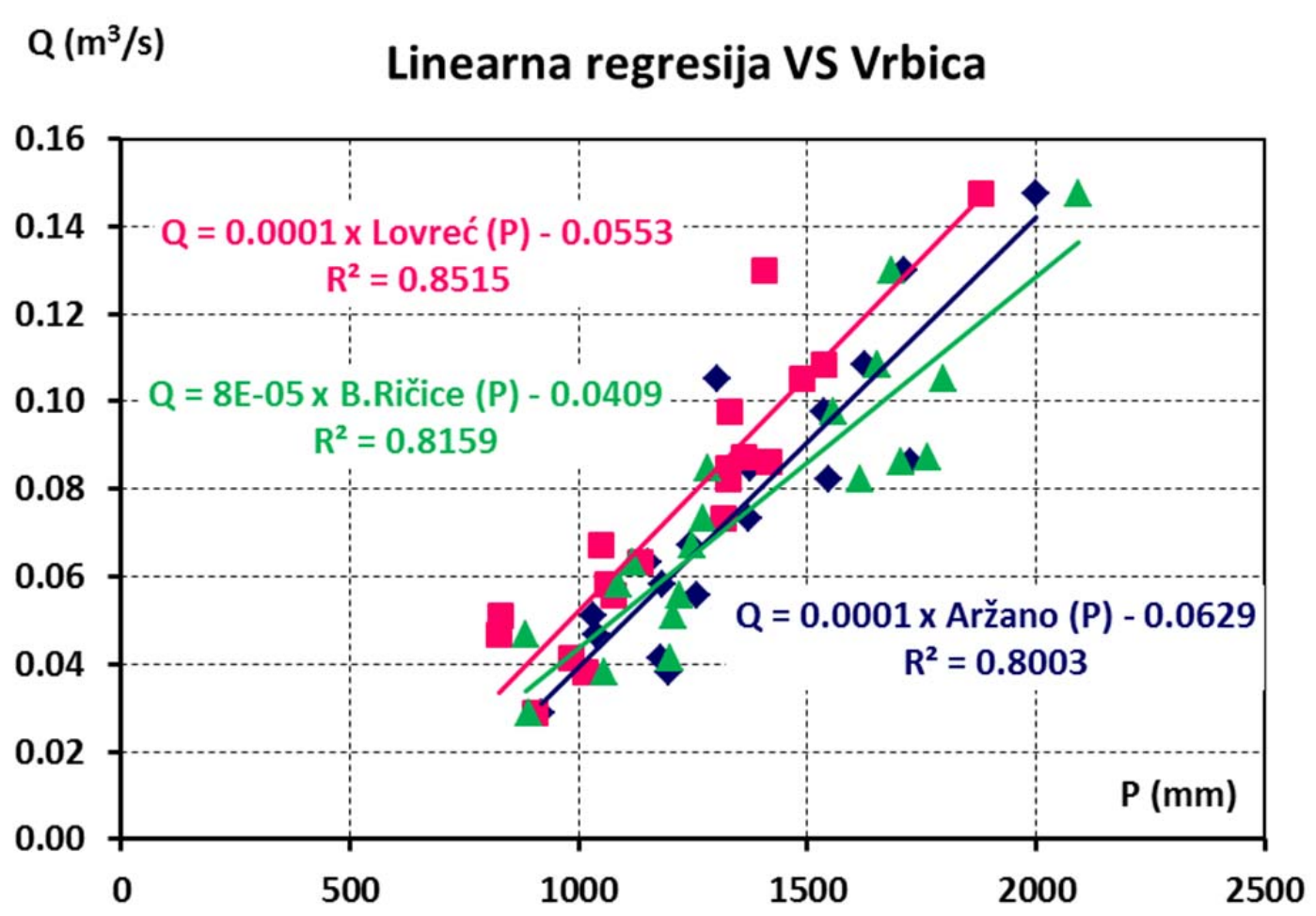

Slika 2.7. Odnosi srednjih godišnjih protoka $Q\left(\mathrm{~m}^{3} / \mathrm{s}\right)$ i ukupnih godišnjih padalina $\mathrm{P}(\mathrm{mm}) \mathrm{za}$ VS Vrbica

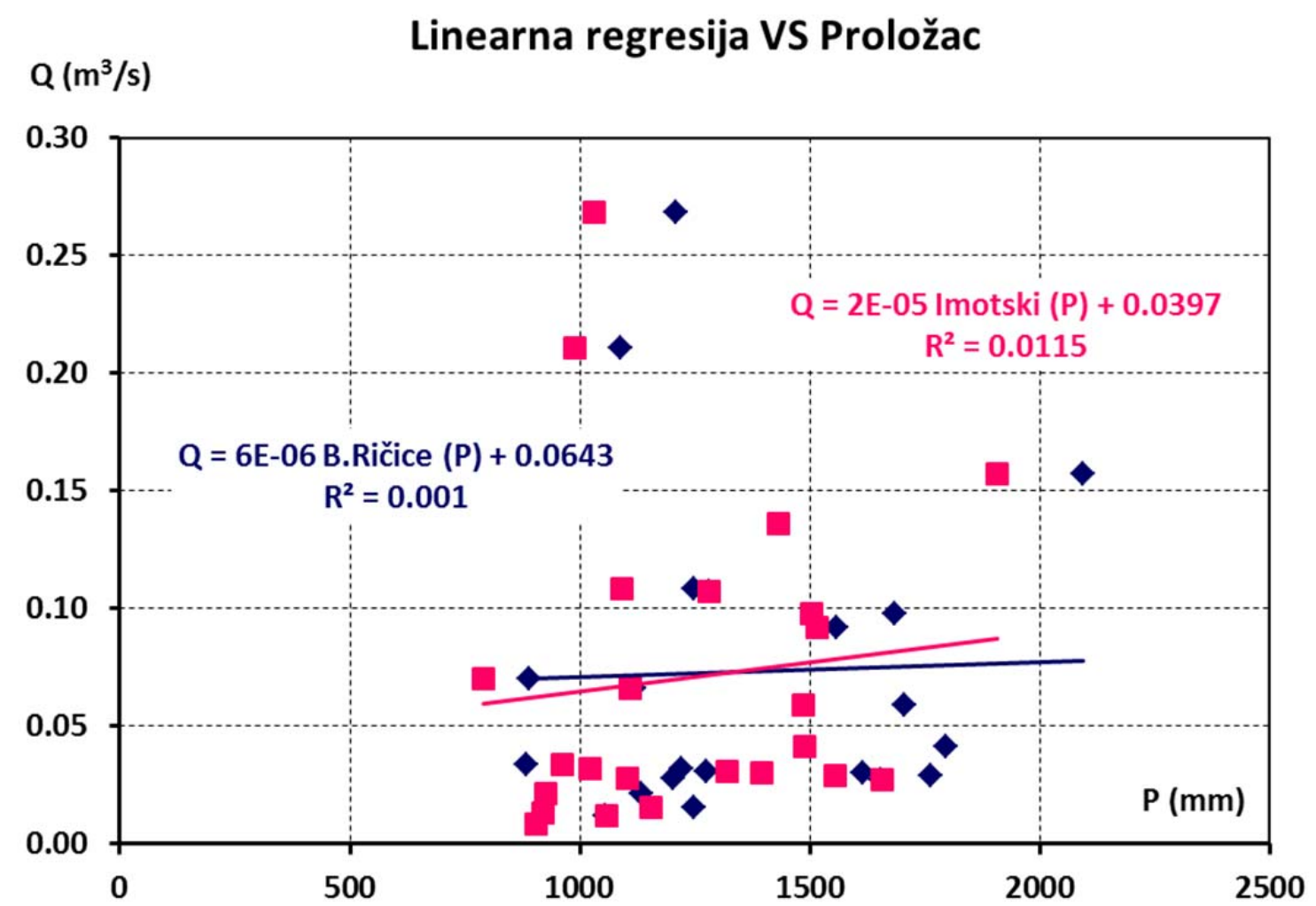

Slika 2.8. Odnosi srednjih godišnjih protoka $Q\left(\mathrm{~m}^{3} / \mathrm{s}\right)$ i ukupnih godišnjih padalina $\mathrm{P}(\mathrm{mm}) \mathrm{za}$ VS Proložac 


\section{$\mathrm{Q}\left(\mathrm{m}^{3} / \mathrm{s}\right)$}

\section{Linearna regresija VS Šumet}

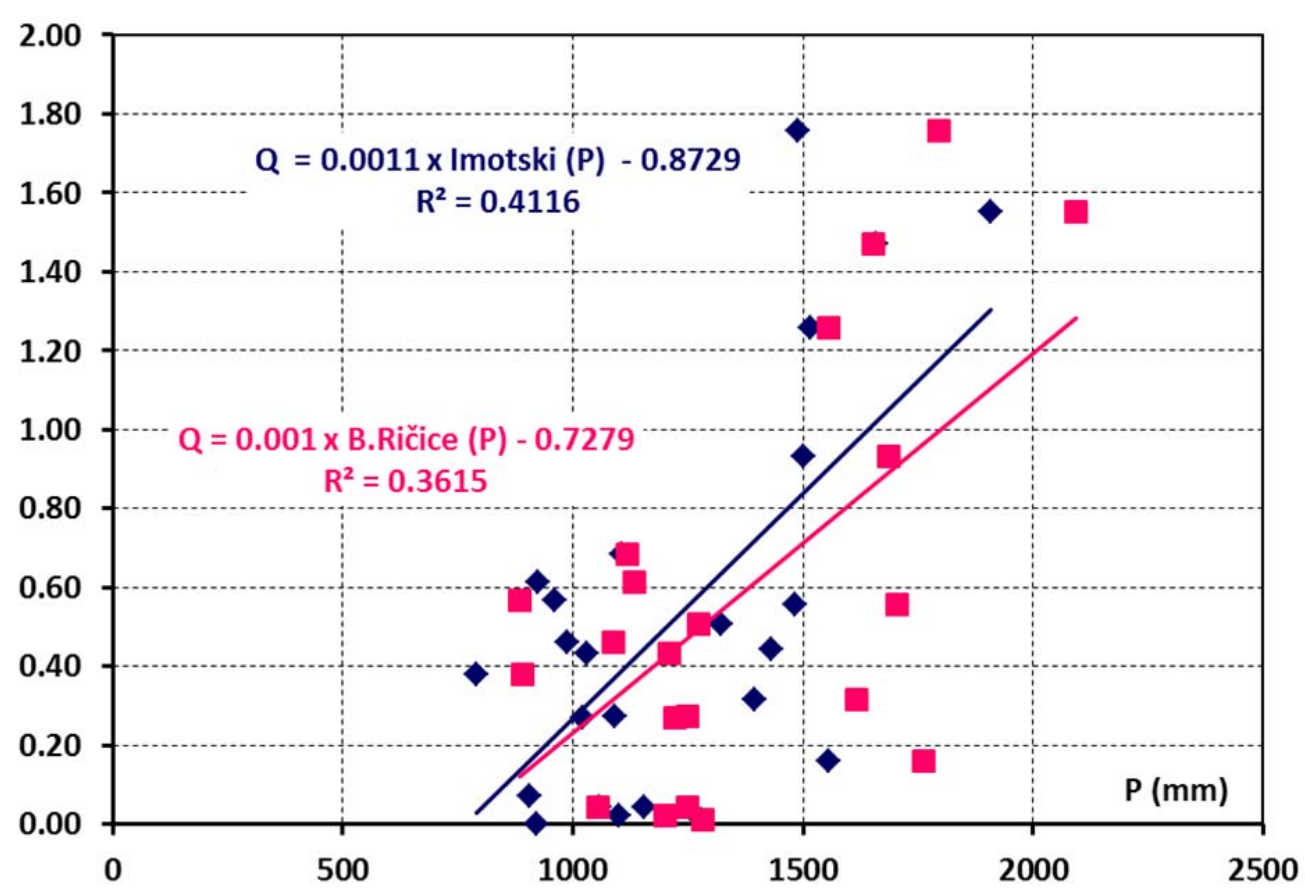

Slika 2.9. Odnosi srednjih godišnjih protoka $Q\left(\mathrm{~m}^{3} / \mathrm{s}\right)$ i ukupnih godišnjih padalina $P(\mathrm{~mm})$ za VS Šumet

$$
Q\left(m^{3} / s\right)
$$

Linearna regresija VS Opačac

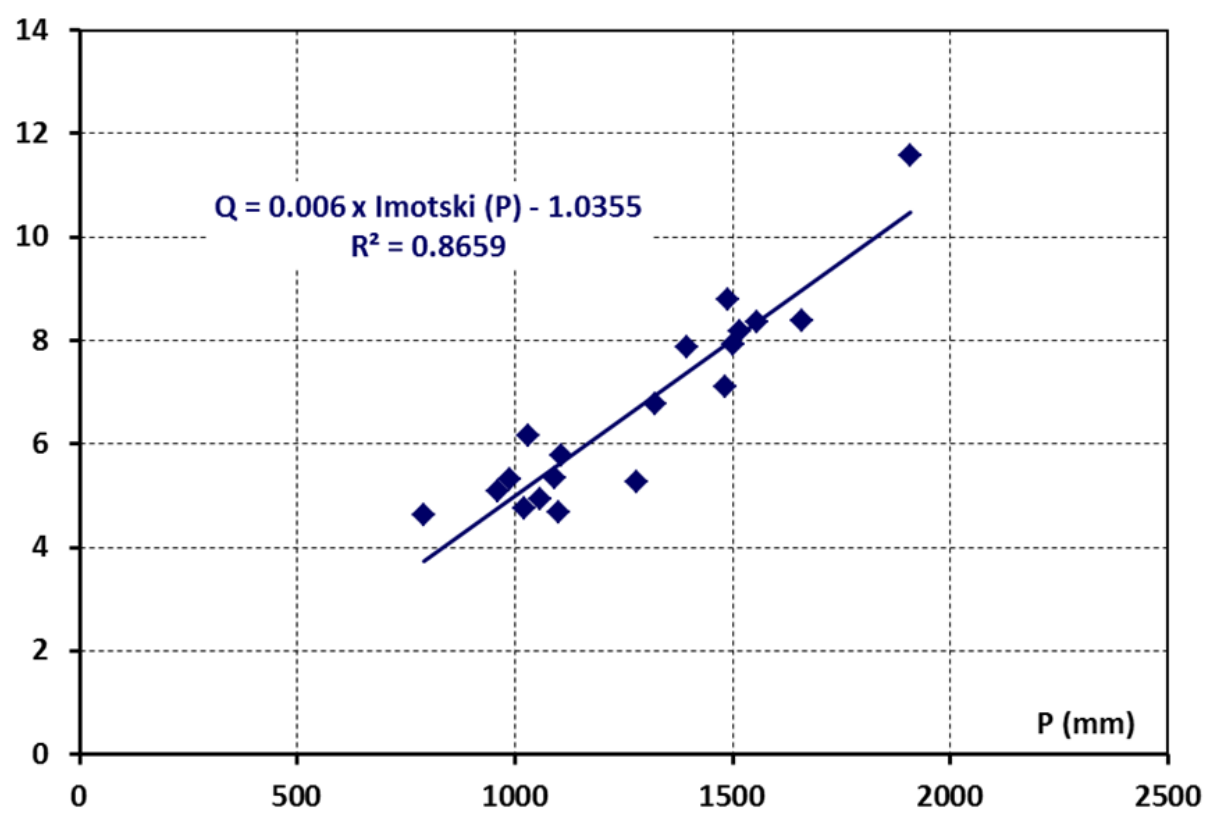

Slika 2.10. Odnosi srednjih godišnjih protoka $Q\left(\mathrm{~m}^{3} / \mathrm{s}\right)$ i ukupnih godišnjih padalina $\mathrm{P}(\mathrm{mm}) \mathrm{za}$ VS Opačac 


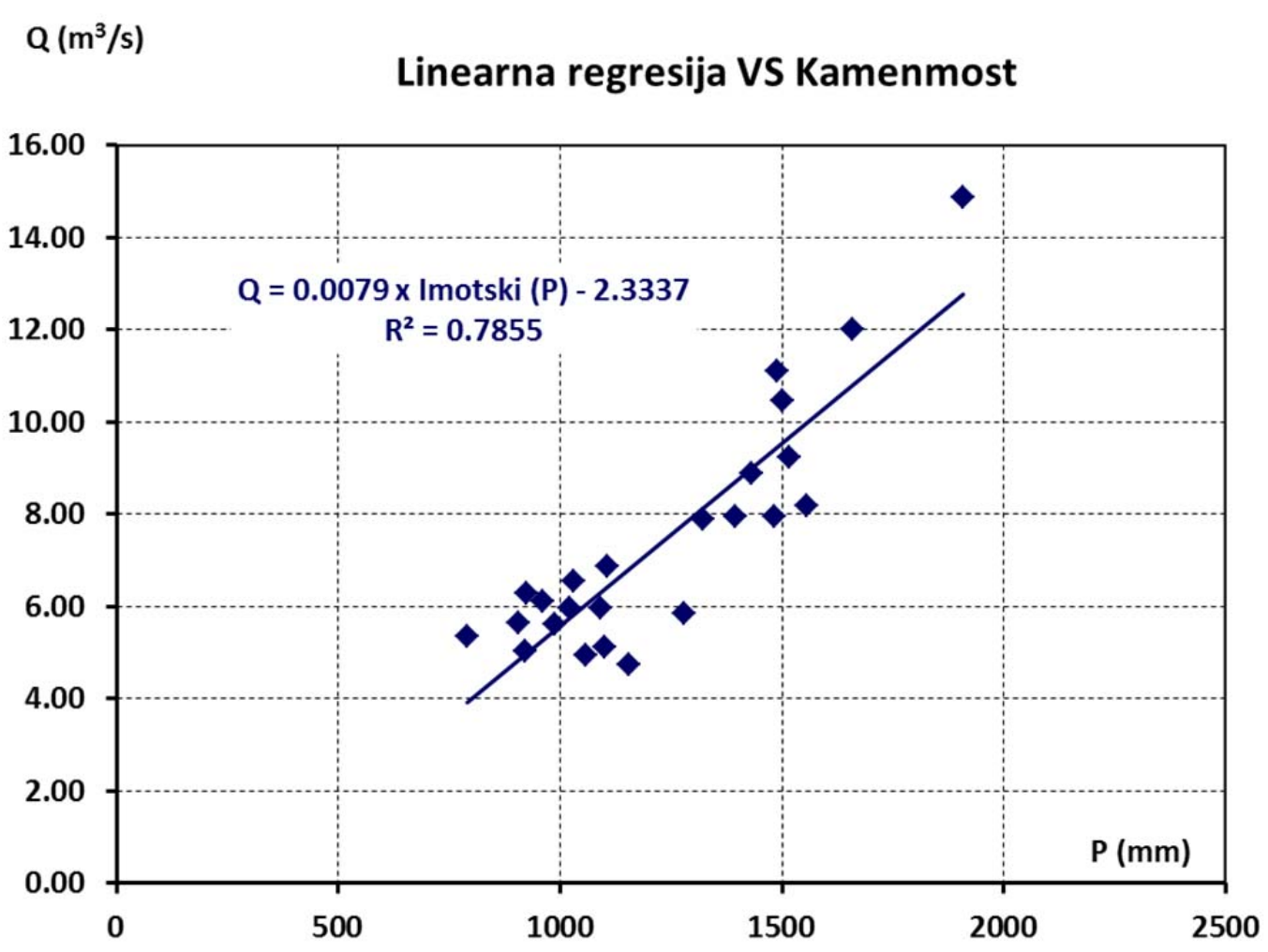

Slika 2.11. Odnosi srednjih godišnjih protoka $Q\left(\mathrm{~m}^{3} / \mathrm{s}\right)$ i ukupnih godišnjih padalina $\mathrm{P}(\mathrm{mm}) \mathrm{za}$ VS Kamenmost

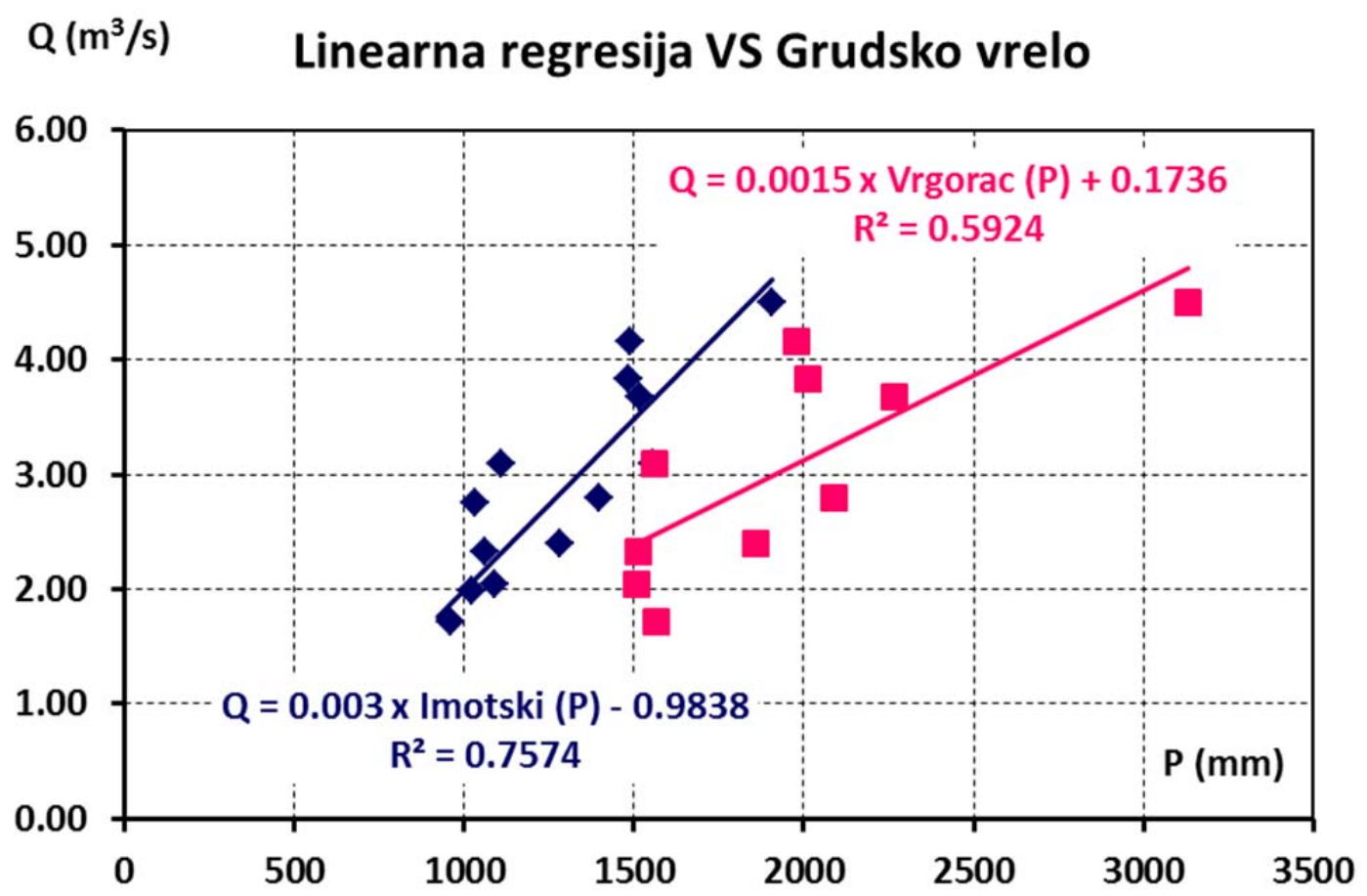

Slika 2.12. Odnosi srednjih godišnjih protoka $Q\left(\mathrm{~m}^{3} / \mathrm{s}\right)$ i ukupnih godišnjih padalina $\mathrm{P}(\mathrm{mm}) \mathrm{za}$ VS Grudsko vrelo 


\section{$\mathrm{Q}\left(\mathrm{m}^{3} / \mathrm{s}\right) \quad$ Linearna regresija VS Peć mlini, niz}

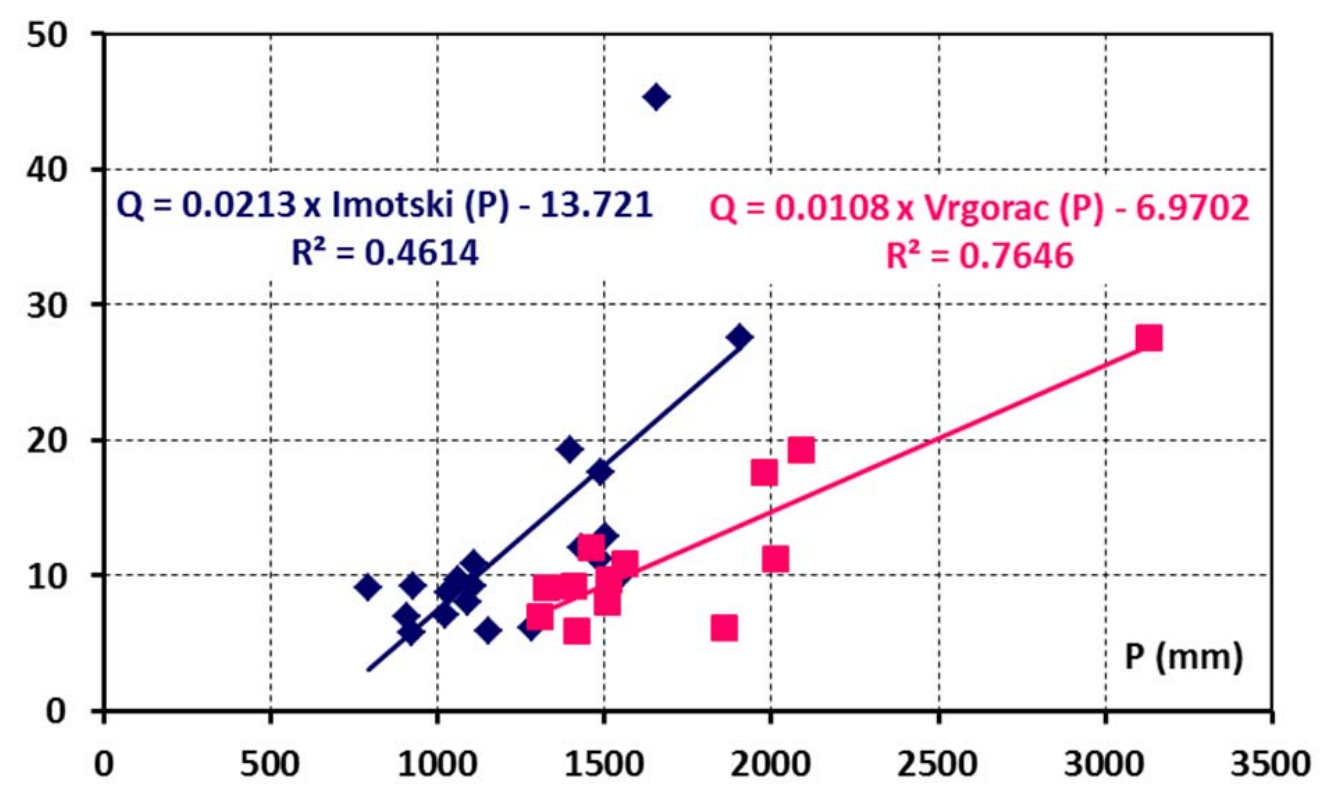

Slika 2.13. Odnosi srednjih godišnjih protoka Q $\left(\mathrm{m}^{3} / \mathrm{s}\right)$ i ukupnih godišnjih padalina $\mathrm{P}(\mathrm{mm}) \mathrm{za}$ VS Peć Mlini, nizvodno

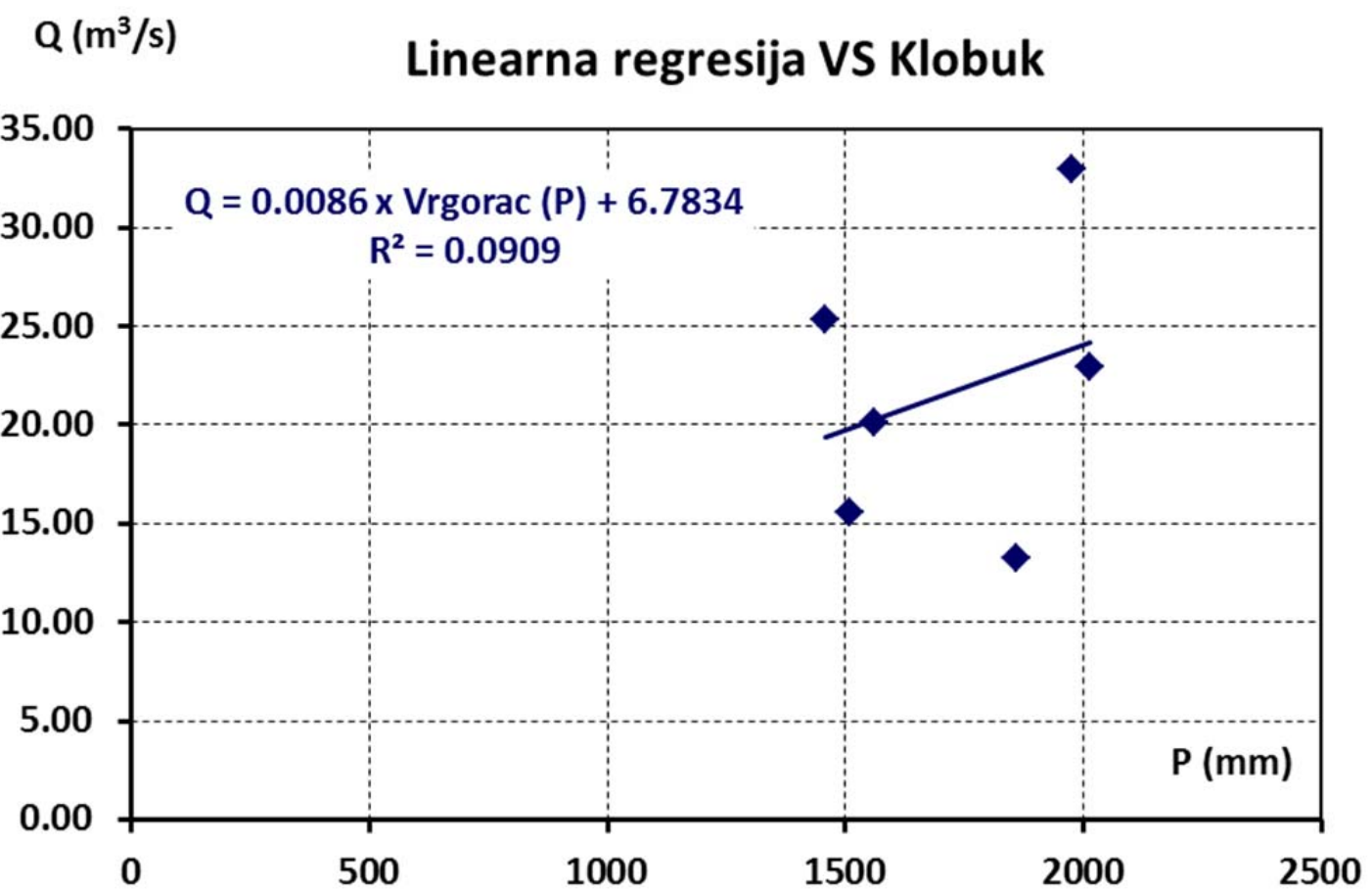

Slika 2.14. Odnosi srednjih godišnjih protoka Q $\left(\mathrm{m}^{3} / \mathrm{s}\right)$ i ukupnih godišnjih padalina $\mathrm{P}(\mathrm{mm}) \mathrm{za}$ VS Klobuk 


\section{$\mathrm{Q}\left(\mathrm{m}^{3} / \mathrm{s}\right) \quad$ Linearna regresija VS Humac}

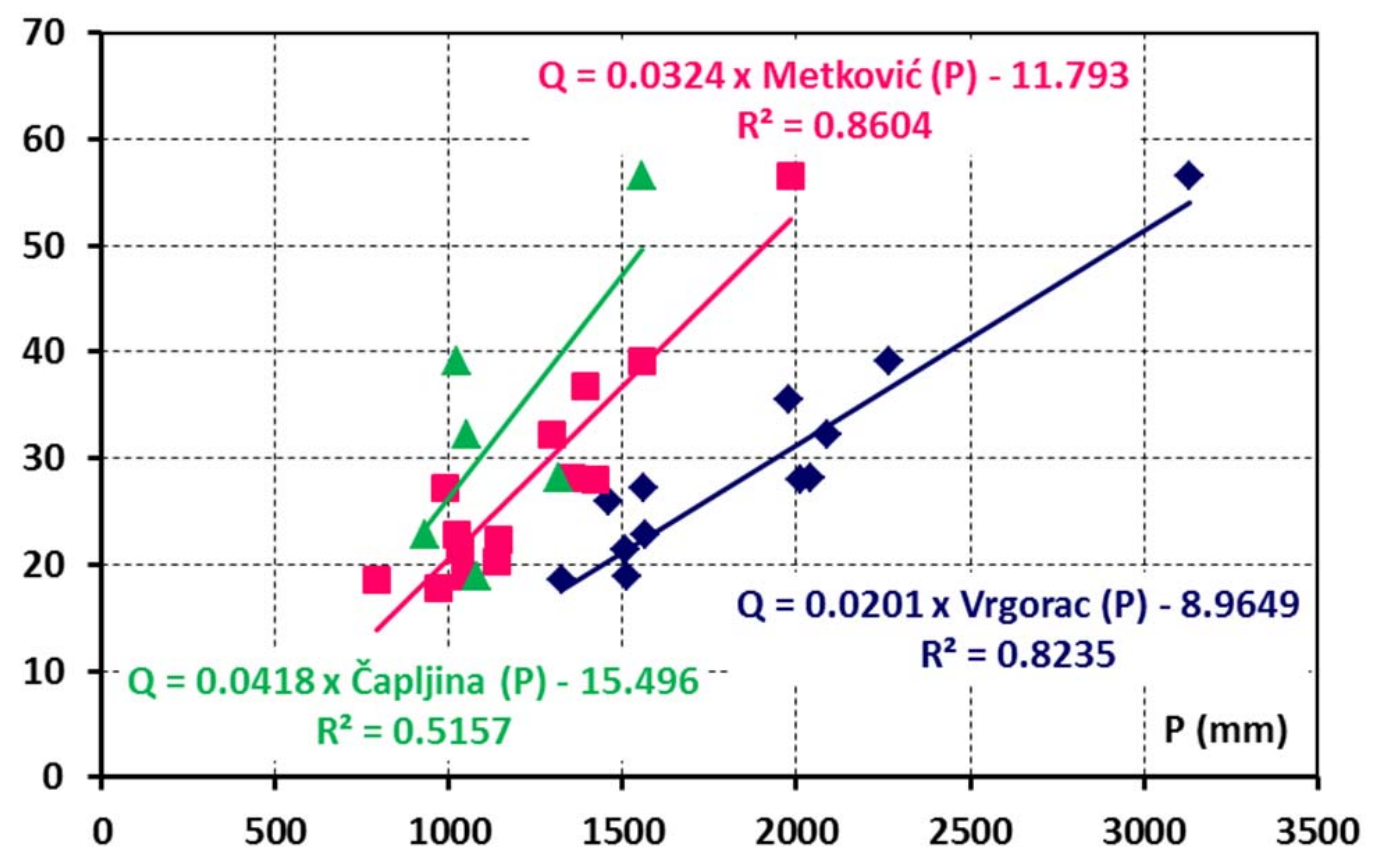

Slika 2.15. Odnosi srednjih godišnjih protoka $Q\left(\mathrm{~m}^{3} / \mathrm{s}\right)$ i ukupnih godišnjih padalina $\mathrm{P}(\mathrm{mm}) \mathrm{za}$ VS Humac

VS Šumet, Proložac i Klobuk pokazuju najveće osipanje rezultata pa time i najmanje vrijednosti $\mathrm{R}^{2}$ koja u ovom slučaju uspoređuje srednje godišnje vrijednosti protoka i procjene tih vrijednosti definirane regresijskim pravcem. U slučaju VS Šumet i VS Proložac uzrok se može tražiti u činjenici da se radi o stanicama na prekidnim - influentnim - tokovima čiji ekstremno mali protoci (blizu nula ili nula) ne doprinose ukupnoj regresiji. U slučaju VS Klobuk radi se o malom broju podataka koji ulazi u analizu (6 godina).

\subsubsection{Spektralna analiza}

Analiza vremenski serija, razvijena prvenstveno prema Jenkins i Watts (1968), Hannan (1970), Brillinger (1975) te Box i Jenkins (1976) primijenjena je u mnogim hidrološkim istraživanjima (Padilla i Pulido-bosch, 1995; Larocque et al. 1998; Labat et al. 2000; Samani, 2001, Jukić i Denić-Jukić, 2004; Panagopoulos i Lambrakis, 2006 i mnogi drugi). Mnoge hidrološke studije u svojim preliminarnim istraživanjima koriste ovakav pristup probiranja podataka zbog mogućnosti korištenja lako dostupnih podataka, jednostavno se implementiraju u istraživanje i često daju dobar uvid u krški akvifer (Larocque, 1998). Spektralna analiza bazirana je na 
sistemskom pristupu korištenje statističkih funkcija. Mangin (1984) je razvio metodologiju korištenjem ove analize za studiranje odnosa ulazno-izlaznih varijabli u krškim vodonosnicima. Akvifer se promatra kao filter koji transformira, retencira ili eliminira ulazni signal prilikom stvaranja izlaznog signala. Stupanj transformacije ulaznog signala stoga daje važne informacije o prirodi otjecanja u sistemu. Mangin (1984) i Padilla i Pulido-Bosch (1995) demonstrirali su kako se navedene metode mogu koristi kod režima otjecanja izvora u kršu za bolje razumijevanje globalne dinamike krškog akvifera. Cilj ovog dijela istraživanja je na osnovu dobivenih rezultata spektralne analize primijeniti tumačenja autokorelacijske i kroskorelacijske funkcije te dobiti odgovore o memoriji sistema, dužini odgovora izlaznog signala (eng. lag time) i periodičnosti.

Autokorelacijska funkcija (ACF) se definira kao omjer između autokovarijance i varijance promatrane vremenske serije. ACF vremenske serije $\{x t\}, t=0,1,2, \ldots, n-1$ je:

$$
r_{x x}(j)=\frac{\gamma_{x x}(j)}{\gamma_{x x}(0)}
$$

gdje su:

$$
\begin{gathered}
\gamma_{x x}(j)=\frac{1}{n} \sum_{t=0}^{n-j}\left(x_{t}-\bar{x}\right)\left(x_{t+j}-\bar{x}\right) \\
\bar{x}=\frac{1}{n} \sum_{t=0}^{n-1} x_{t}
\end{gathered}
$$

te gdje je vremenski korak $j=0,1,2, \ldots, m, m<n-1$. Dužina vremenske serije označena je sa $n, x$ je jedan događaj, $\bar{x}$ je srednja vrijednost a $m$ je tzv. "točka rezanja" (eng. cutting point) koja određuje veličinu intervala na kojem se vrši analiza - time se zaobilaze mogući problemi kao efekt memorije godišnjih ili više-godišnjih ponavljanja.

Osnovna korelacijska analiza kvantificira linearnu ovisnost uzastopnih vrijednosti za promatrani vremenski period (Larocque at al, 1998.). Korelogram $\gamma_{x x}(j)$ ocrtava memoriju sistema - ako događaj ima dugoročni utjecaj na vremensku seriju, nagib autokorelacijske funkcije $r_{x x}(j)$ polagano opada. Prema Mangin (1984) prag pouzdanosti je vrijednost ACF $<0.2$ ispod koje vremenska serija više nije autokorelirana. Padaline prikupljene sa razmatranih stanica su stohastički procesi, gdje vrijednosti ACF za $j=1$ dan imaju nešto veću autokorelaciju (raspon 0.24 - 0.30), dok za ostale vremenske lag-ove one iznose manje od 0.2. Vremenske serije oborina imaju dva različita početka mjerenja - 1.1.1990 i 1.1.1995 pa su se prema njima odredile ACF prikazane na slikama 2.16 i 2.17. Vidljivo je da VS Jovića most, VS Ričice i VS Šumet pokazuju ne postojanje memorije sustava (Slika 2.16.). VS Šumet, VS Kamenmost i VS Peć Mlini pokazuju postojanje godišnje periodičnosti a pamćenje sustava, definirano kao vremenski korak $j$ gdje je vrijednost ACF manja od 0, je oko 100 dana. 


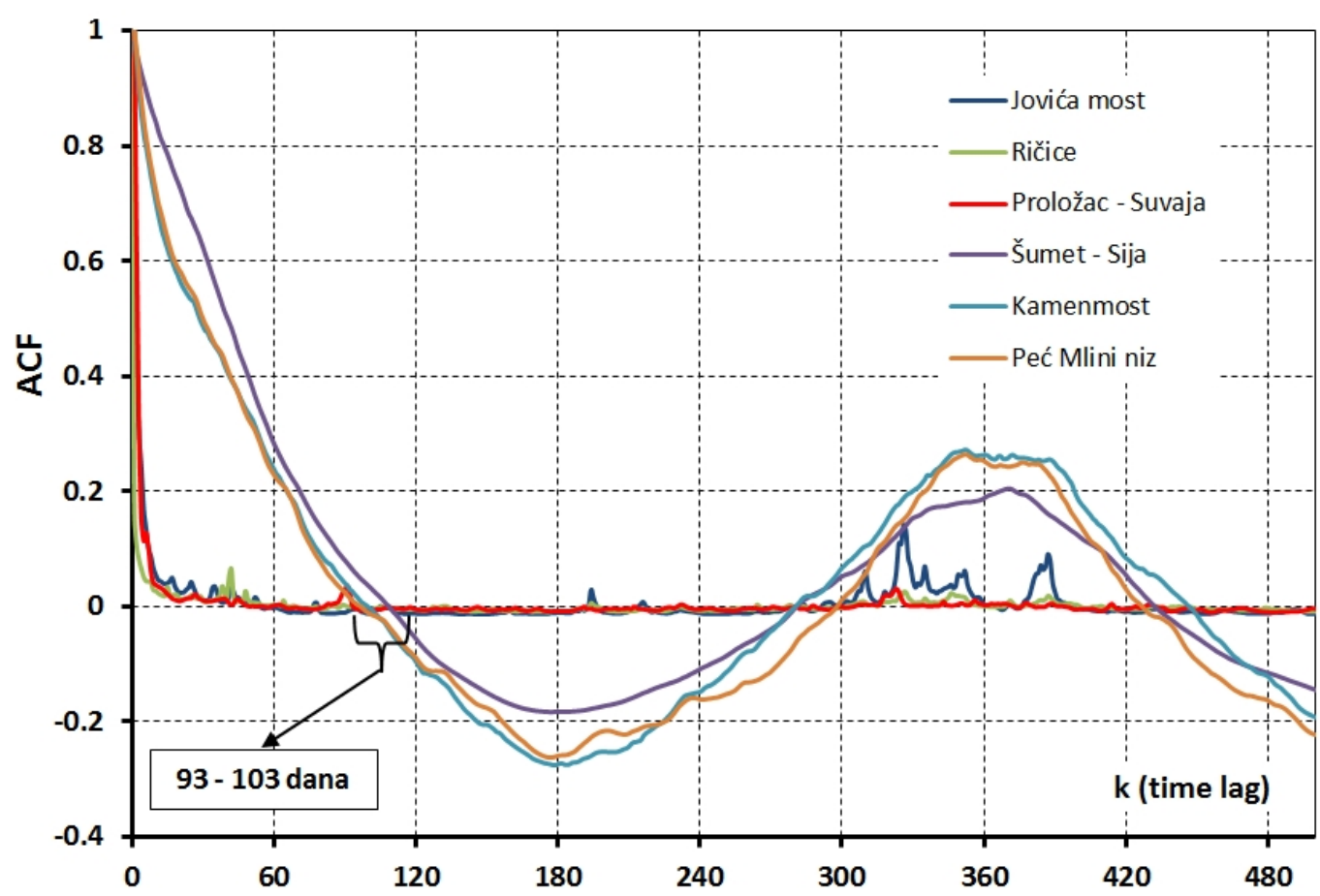

Slika 2.16. Autokorelacijske funkcije za vodomjerne stanice VS Jovića most, VS Ričina Ričice, VS Proložac, VS Šumet, VS Kamenmost i VS Peć Mlini,niz

Opažena otjecanja na vodomjernim stanicama na Slika 2.17. pokazuju da je i u ovom slučaju memorija sustava duga - 100 dana ali je linearna međuzavisnost različita.

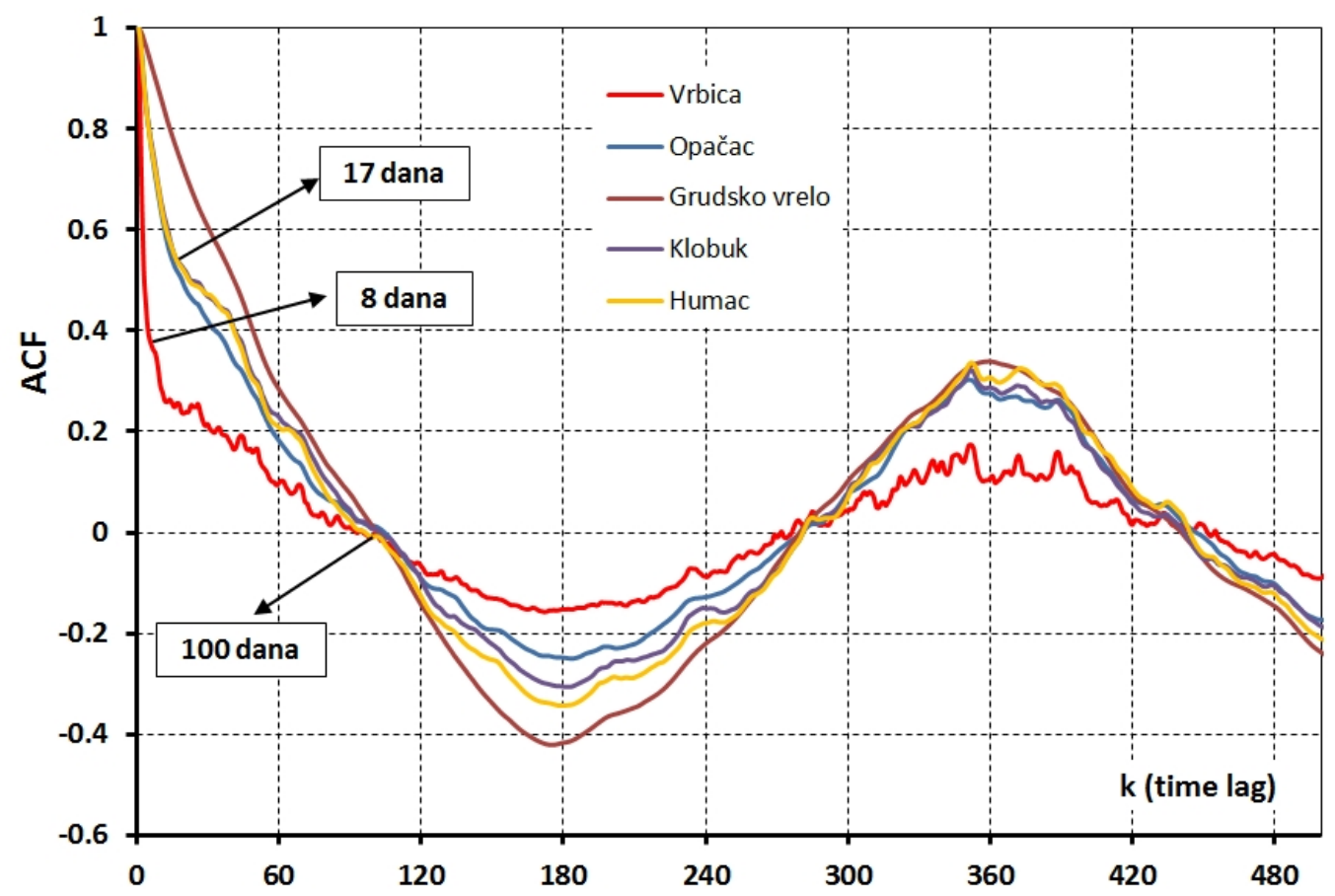

Slika 2.17. Autokorelacijske funkcije za vodomjerne stanice VS Vrbica, VS Opačac, VS Grudsko vrelo, VS Klobuk i VS Humac 
Najkraće uočena - 8 dana vidljiva je kod VS Vrbica te bi mogla ukazivati na postojanje komponenti brzog i sporog otjecanja. Nešto duža linearna ovisnost $j \approx 17$ dana pokazuju stanice Opačac, Klobuk i Humac te se i ovi rezultati mogu protumačiti kao naznaka dualnog sistema. Izvor Grudsko vrelo ne pokazuje postojanje linearne međuovisnosti pa pretpostavlja da se na ovom izvoru javlja samo sporo tečenje.

Kroskorelacijska funkcija (CCF) između dviju vremenskih serija $\left\{\mathrm{x}_{\mathrm{t}}\right\}$ i $\left\{\mathrm{y}_{\mathrm{t}}\right\}$ opaženih $\mathrm{u}$ trenucima $t=0,1,2, \ldots, n-1$ računa se putem izraza:

$$
r_{x x}(j)=\frac{\gamma_{x y}(j)}{\sqrt{\gamma_{x x}(0) \gamma_{y y}(0)}}
$$

gdje je:

$$
\gamma_{x y}(j)=\frac{1}{n} \sum_{t=1}^{n-j}\left(x_{t}-\bar{x}\right)\left(y_{t+1}-\bar{y}\right)
$$

CCF utvrđuje vezu između ulazne i izlazne vremenske serije. Ako se ulazna vremenska serija može smatrati nizom nezavisnih slučajnih događaja, oblik CCF odgovara obliku trenutnog jediničnog hidrograma. Kod ovakvih analiza kao ulazna vremenska serija koriste se ukupne dnevne oborine što je gruba aproksimacija je odgovor sustava u stvarnosti generiraju efektivne oborine. Iz tog razloga, CCF uglavnom pruža informacije o obliku i značajnosti veze između ulazne i izlazne vremenske serija. Ako je CCF ne simetrična i ako je $r_{x y}(j)>0$ za $j>0$, ulazni signal ima utjecaja na izlazni signal, dok ako je $r_{x y}(j)>0$ za $j<0$, izlazni signal ima utjecaja na ulazni signal. Potpuno simetričan oblik CCF oko $j=0$ pokazuje da ulazni i izlazni signal nisu međusobno zavisni, odnosno da su pod utjecajem trećeg nezavisnog signala. Vrijednost vremenskog koraka $j$ kod kojeg CCF dostiže svoj maksimum definira brzinu odgovora sustava.

\begin{tabular}{|c|c|c|c|c|c|c|c|c|c|}
\hline & \multicolumn{8}{|c|}{ Kišomjerne stanice } \\
\hline & & Aržano & Lovreć & Ričice & Imotski & Vrgorac & Metković & Čapljina & Mostar \\
\hline \multirow{11}{*}{ 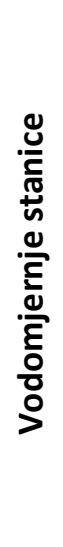 } & Jovica most & - & - & - & 0.4720 & - & - & - & - \\
\hline & Ričina & - & - & 0.6069 & 0.0749 & - & - & - & - \\
\hline & Vrbica & - & 0.0795 & 0.6418 & - & - & - & - & - \\
\hline & Proložac & - & - & 0.0008 & 0.0026 & - & - & - & - \\
\hline & Šumet & - & - & 0.1390 & 0.2533 & - & - & - & - \\
\hline & Opačac & - & - & - & 0.8659 & - & - & - & - \\
\hline & Kamenmost & - & - & - & 0.7855 & - & - & - & - \\
\hline & Grudsko vrelo & - & - & - & 0.4809 & 0.2162 & - & - & - \\
\hline & Peć Mlini niz & - & - & - & 0.2502 & 0.3501 & - & - & - \\
\hline & Klobuk & - & - & - & - & 0.0909 & - & - & - \\
\hline & Humac & - & - & - & - & 0.2971 & 0.2632 & 0.1719 & - \\
\hline
\end{tabular}

Tablica 2.8. Rezultati linearne regresije i težinskih koeficijenata Thiessenovih poligona 
Za svaku od promatranih VS (izlazna vremenska serija) određenja je ulazna vremenska serija padalina koja prema prethodnoj analizi linearne regresije dalje najbolje rezultate te je ta vrijednost umnožena sa rezultatom utjecaja pojedine KS prema analizi Thiessenovih poligona (Tablica 2.8). Na slici 1.18. prikazane su kroskorelacijske funkcije za četiri VS - Jovića most, Ričina, Vrbica i Proložac. Sve navedene stanice pokazuju brzi odgovor sustava - ne uočava se kašnjenje izlazne serije sa ulaznom. Stanice imaju linearni odgovor na padaline 3-4 dana, nakon čega odgovor ima karakteristike bijelog šuma (ne uočavaju se nikakve značajnije korelacije) $s$ tim da su vrijednosti kroskorelacijske funkcije za VS Proložac redovito manje od statistički značajnih 0.2 prema Mangin-u.

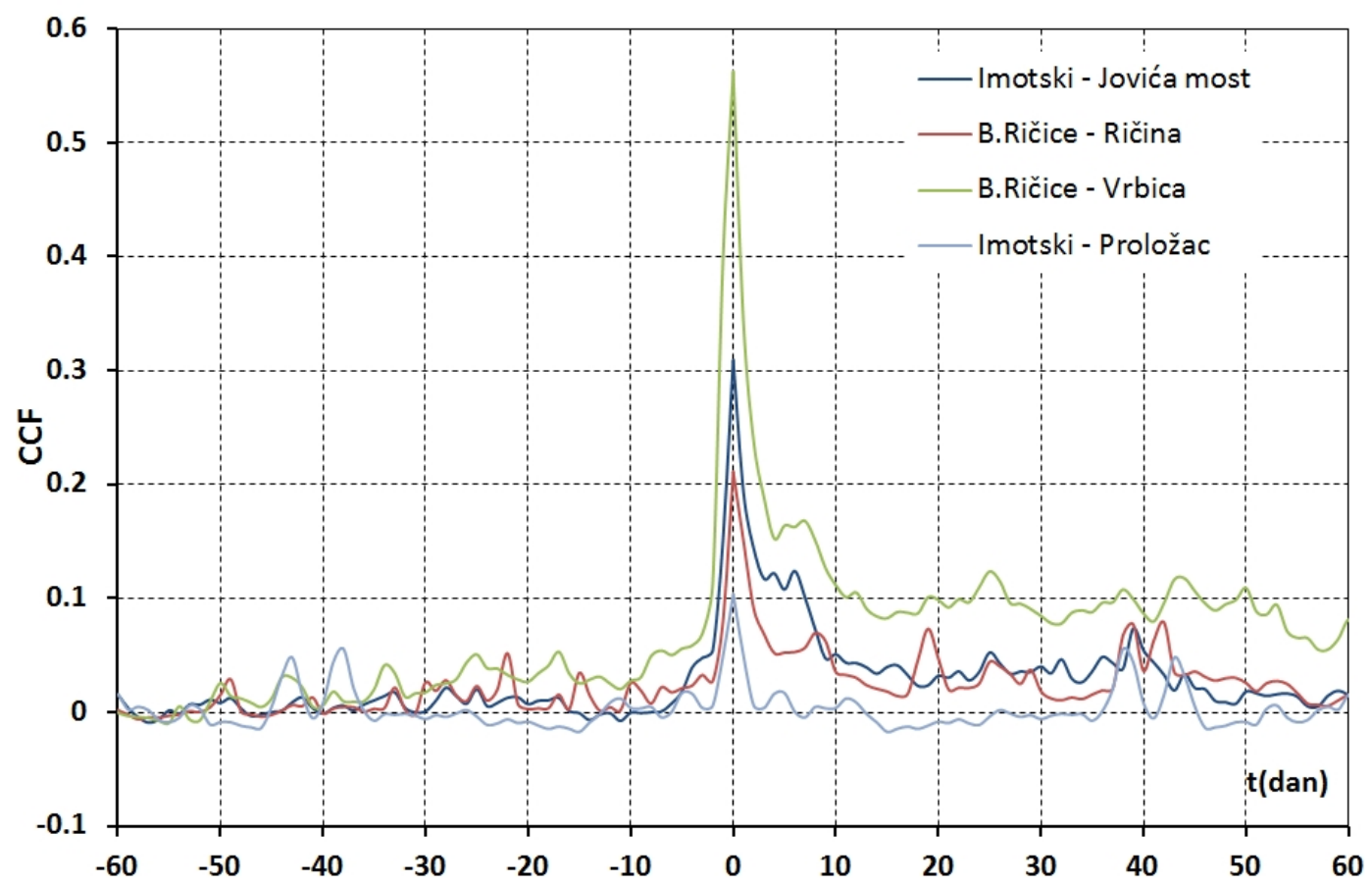

Slika 2.18. Kroskorelacijska funkcija za VS: Jovića most, Ričina, Vrbica i Proložac

Vodomjerne stanice Opačac i Kamenmost su udaljene svega nekoliko kilometara, a glavna razlika među njima je da se sve vode koje su izmjerene sa izvora Opačac, ne mjere na VS Kamenmost, zbog postojanja dodatnih kanala za navodnjavanje između navedenih stanica. Ovu tvrdnju moguće je povezati i sa odgovorom CCF-a koji je nešto bolji za VS Opačac (Slika 2.19). Na slici 2.19. je prikazan i izvora Grudsko vrelo, koji se kao i Opačac nalazi u Imotskom polju ali je njihov odgovor na ulaznu seriju padalina različit - Grudsko vrelo ima kašnjenje od 3 dana te ne pokazuje linearni trend pa se pretpostavlja da ovaj izvor sadrži samo sporu komponentu otjecanja. VS Šumet (kao i VS Proložac, slika 2.18) su prekidnog toka i bez utjecaja padalina na njihov zabilježeni protok - ovdje se zapravo radi o kanalima koji su pod antropogenim utjecajem te je takvo ponašanje očekivano. 


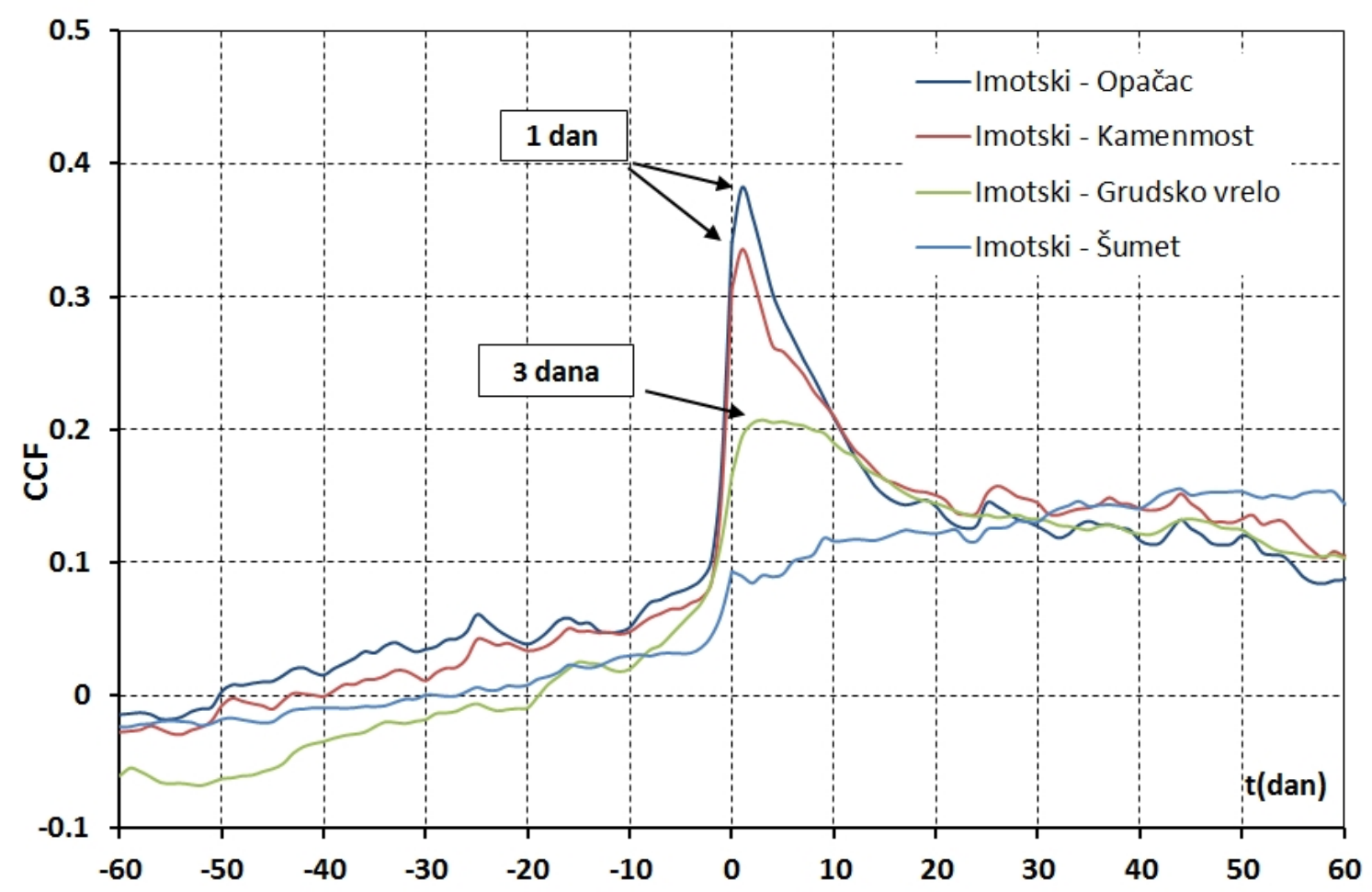

Slika 2.19. Kroskorelacijska funkcija za VS: Opačac, Kamenmost, Grudsko vrelo, Šumet

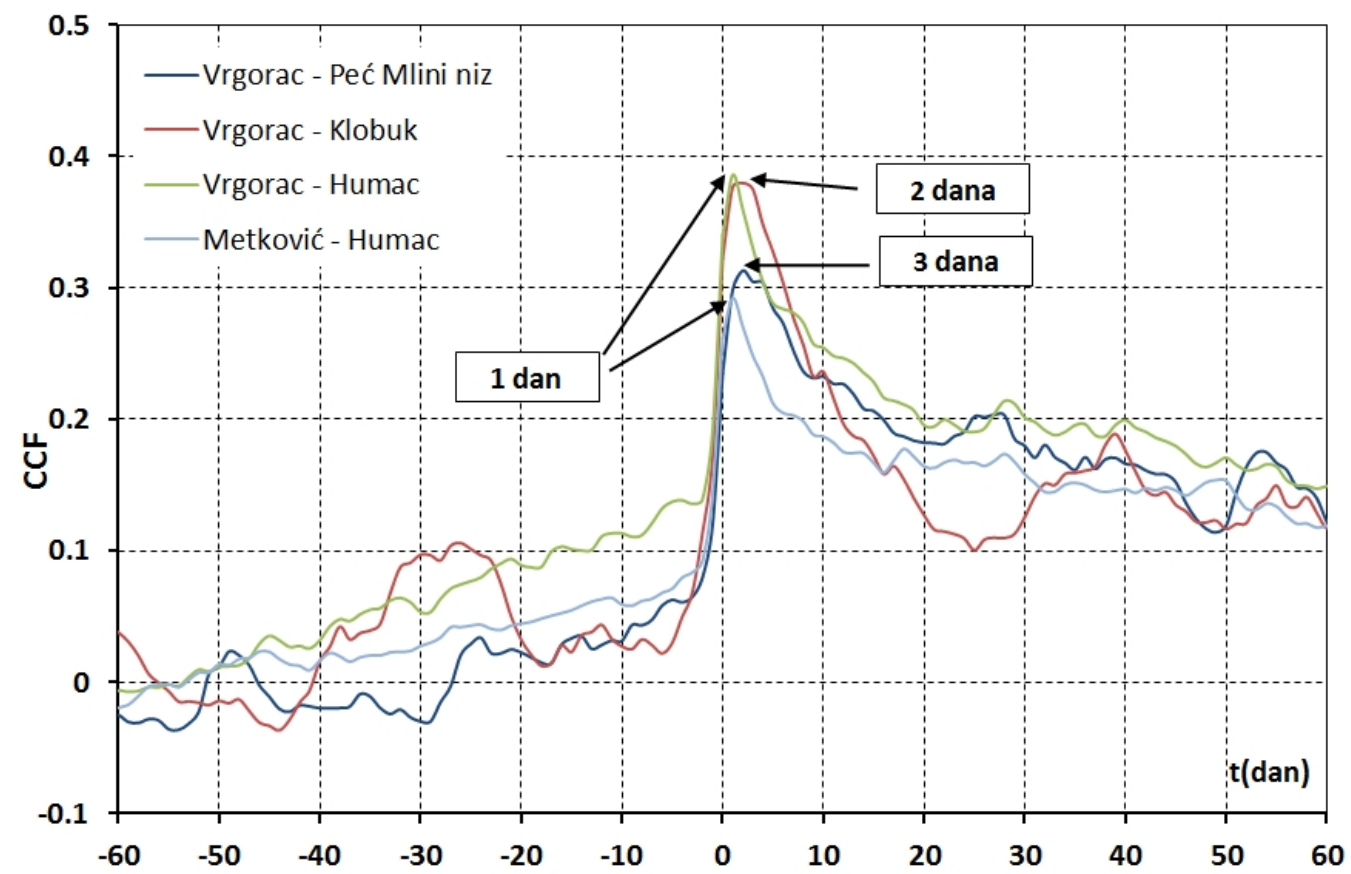

Slika 2.20. Kroskorelacijska funkcija za VS: Peć Mlini niz, Klobuk i Humac

Kroskorelacijska funkcija za VS Peć Mlini, Klobuk i Humac (Slika 2.20.) pokazuje različita vremena zaostajanja ovisna o kiši izmjerenoj na MS Vrgorac - najudaljenija VS Peć Mlini odgovara na padaline nakon 3 dana, VS Klobuk nakon 2 dana te VS Humac nakon 1 dan. Prikazan je i odnos VS Humac - MS Metković pošto su težinski koeficijenti (Tablica 2.8.) za VS 
Humac - MS Vrgorac (0.2971) i VS Humac - MS Metković (0.2632) vrlo bliski, no ova analiza je pokazala da je odgovor VS Humac i dalje 1 dan uz nešto smanjenu vrijednost CCF za lag $=0$ kod MS Metković.

\subsubsection{Rasprava i zaključci}

Sa hidrološkog gledišta, glavna prepreka kvalitetnoj analizi ovoga sistema predstavlja nedostatak kontinuiranih praćenja NPV-a tj. karakterizacija kompleksne organizacije podzemnih provodnika krškog akvifera jedini je put prema točnijem opisivanju krških izvora i zaštiti vodnih resursa (Perrin i Luetscher, 2008; Pardo-Iguzquiza et al. 2011). Vremenska i prostorna varijabilnost kao i utvrđivanje parametara provodnika ekstremno je osjetljiv i kompleksan zadatak stoga je neophodno u analizu uključiti regionalne geomorfološke i druge procese koji mogu utjecati na transport vode uz naglasak da aplikacija konvencionalnih metoda i modela rijetko donosi zadovoljavajuće rezultate (Radulović et al. 2012.). No iako navedenih istraživanja nema, osnovni statistički alati korišteni u ovom poglavlju donijeli su nove spoznaje o karakteristikama sliva rijeke sa 8 imena. Prikupljeni podaci o oborinama pokazuju da se radi o količinama koje su ravnomjerno raspoređene na cijelom području, što ukazuju visoke vrijednosti koeficijenata korelacije (Tablice 2.2. - 2.4.). Time se otvara mogućnost osrednjavanja ili smanjenja broja korištenih kišomjernih stanica u konceptualnim i parametarskim modelima koji se temelje na što dužem nizu opaženih karakteristika sliva. Nerealno je koristiti stanicu koja ima npr. samo 6 kontinuiranih godina opažanja (MS Vrgorac) te tu vremensku seriju dodatno "usitniti" na pod-periode kalibracije, testiranja i validacije. Dodatni problem u određivanju međuovisnosti padalina i otjecanja je njihov prostorni razmještaj. Predlaže se novi način određivanja odnosa kišomjernih stanica pomoću kombinacije metode Thiessenovih poligona i koeficijenata korelacije - on smanjuje broj kombinacija KS -VS koji se žele analizirati a daje i vizualnu reprezentaciju stanja pokrivenosti sliva.

Izvršena spektralna analiza dala je dodatni uvid u linearnu ovisnost padalina i otjecanja. Vremenske serije padalina su stacionarne dok se kod otjecanja uočava godišnja periodičnost. Tumačenje autokorelacijske funkcije otkriva koji dijelovi sliva imaju karakteristike sporog tečenja, sporog i brzog tečenja ili su pod antropogenim utjecajem. Kroskorelacijska funkcija ocjenjuje vrijednosti kašnjenja izlaznog signala za ulaznim koje su mogu iskoristiti prilikom definiranja strukture ulaznih podataka parametarskog modela. Padilla i Pudilo-Bosch (1995) pokazuju mogućnost određivanja udjela brzog i sporog otjecanja prema rezultatima funkcije faze i funkcije prigušenja spektralne analize. Ove tvrdnje definitivno bi bile napredak u opisivanju 
ponašanja promatranog sliva ali velika količina šuma ne omogućuje jasno određivanje ovih parametara te se ova analiza nije prikazala u poglavlju.

Može se zaključiti da bez utvrđenih hidroloških i hidrogeoloških režima nije moguće postići nova saznanja o osjetljivosti krškog sistema, pogotovo ako gospodarski interesi graničnih država nisu usklađeni. Novi konceptualni interdisciplinarni sustavni pristup koji će se opisati u sljedećim poglavljima ima u cilju demistificirati barem dio ovoga veoma kompleksnog, ali i interesantnog i izazovnog područja Dinarskog krša. 


\section{IDENTIFIKACIJA HIDROLOŠKIH REŽIMA OTJECANJA}

\subsection{Uvod}

Hidrogeološke i hidrološke karakteristike krških vodonosnika su kompleksne i vrlo različite od karakteristika ostalih hidrogeoloških područja kao što su pukotinski i granulirani vodonosnici (Bakalowicz, 2005; Goldscheider et al., 2007; Jukić i Denić-Jukić, 2009). Krški vodonosnici su izričito heterogeni s transmisivnim pukotinama i mrežom kanala ugrađenom u matrici stijena slabe propusnosti (Charlier et al. 2012). Njihova struktura uzrokuje složene uvjete podzemnog tečenja zbog postojeće vremenske varijabilnosti, prostorne heterogenosti i diskontinuiranih hidrauličkih parametara. Prema Kiraly-u i suradnicima (1995), direktna posljedica ovakve strukture je niz dvojnosti krških vodonosnika:

1) Dvojnost infiltracijskih procesa

2) Dvojnost polja tečenja podzemne vode

3) Dvojnost uvjeta protoka

Malik i Vojtkova (2012), u analizi recesijske krivulje otjecanja krških izvora, navode postojanje više pod-režima tečenja koje je moguće opisati superponiranjem osnovnih jednadžbi gibanja vode u prirodi: laminarni pod-režimi prema eksponencijalnoj krivulji (2.1) i prema linearnom turbulentnom modelu (2.2.):

$$
Q_{t}=Q_{0} e^{-\alpha t}
$$




$$
Q_{t}=Q_{0}(1-\beta t)
$$

Kombinacija odnosa navedenih režima kao i definiranje veličine parametara $\alpha$ i $\beta$ predstavlja glavni cilj mnogih hidroloških istraživanja kao i jednostavnog konceptualnog RR modela koji će se opisati. Konceptualni model je podijeljen u dva pod-modela. Prvi model koristi mjerene podatke: dnevne oborine, srednju dnevnu temperaturu i relativnu vlažnost za proračun efektivne oborine vodne bilance Palmerovom metodom (1965). Tako izračunata efektivna oborina predstavlja ulazni podatak za drugi model koji izračunava dnevne protoke simulirajući rad dvaju linearnih rezervoara. Kvaliteta modela iskazana je nizom statističkih parametara:

- $\quad$ Nash-Sutcliffeov koeficijent (Nash i Sutcliffe, 1970)

- $\quad$ analiza korelacije

- $\quad$ analiza pogreške: srednja kvadratna pogreška, suma kvadratnih pogrešaka i korijen srednje kvadratne pogreške

Model vrši procjenu komponenti bilance podzemnih voda na četiri krška izvora u slivu rijeke sa 8 imena za kojih je uočena dovoljno duga vremenska serija: Opačac i Grudsko vrelo u Imotskom polju, izvor Tihaljine u čijoj se neposredno blizini nalazi VS Peć Mlini nizvodno te izvor Klokun (VS Klobuk). U Tablici 2.1. prikazane su srednje, minimalne i maksimalne dnevne vrijednosti oborina, temperature, vlažnosti i protoka te analizirani periodi. Iako smješteni u istom polju, Opačac i Grudsko vrelo pokazuju različitu izdašnost zbog kompleksne strukture koju karakterizira duboko i nepravilno okršavanje izraženo utjecajem tektonike, inverznih rasjeda i različitih debljina aluvijalnih naslaga. Vode sa gornjeg horizonta, Imotskog polja, pojavljuju se na donjem horizontu kao rijeka Tihaljina gdje dio voda na izvire na istoimenom izvoru a dio se evakuira tunelom Pećnik (izgrađen 1950.) brzotokom u Tihaljinu. Zbirne vode brzotoka i vrela kontroliraju se na VS Peć Mlini, niz. Na području stanice su zabilježeni antropogeni utjecaji kanala za navodnjavanje u vegetacijskom razdoblju kao i rad Kule zatvaračice koja kontrolira tok evakuacijskog tunela Pećnik. Nizvodno na rijeci Tihaljini postoji niz povremenih i stalnih izvora od kojih je najznačajnije Modro Oka ali tek nakon ušća izdašnog izvora Klokun, Tihaljina se znatno obogaćuje vodom. U ljetnim mjesecima, naročito u ekstremnim sušnim godinama Tihaljina gotovo presuši do Klokuna pa ovaj izvor (sa minimumom cca $2,5 \mathrm{~m}^{3} / \mathrm{s}$ ) znatno poveća protok malim i srednjim vodama. Uz izvor postoje kanali za navodnjavanje koji vjerojatno remete prirodne protočne krivulje zabilježene na VS Klobuk. 
Tablica 3.1. Ulazni podaci za istraživano područje

\begin{tabular}{|c|c|c|c|c|c|}
\hline \multirow{2}{*}{ Ime stanice } & \multirow{2}{*}{ Obzervacija } & \multirow{2}{*}{ Period } & \multicolumn{3}{|c|}{ Dnevne vrijednosti } \\
\hline & & & MIN & AVR & MAX \\
\hline \multirow{3}{*}{ Imotski } & Padaline (mm) & $1990-2013$ & 0 & 3.5 & 163 \\
\hline & Temperatura $\left({ }^{\circ} \mathrm{C}\right)$ & $1990-2013$ & -5.9 & 14.1 & 32.4 \\
\hline & Relativna vlažnost (\%) & $1990-2013$ & 26 & 69.7 & 99 \\
\hline Vrgorac & Padaline (mm) & $\begin{array}{l}1991-1994 \\
1999-2002\end{array}$ & 0 & 4.2 & 131 \\
\hline Grudsko vrelo & Protok $\left(\mathrm{m}^{3} / \mathrm{s}\right)$ & $\begin{array}{l}1995-2002 \\
2006-2010\end{array}$ & 0 & 2.95 & 13.7 \\
\hline Opačac & Protok $\left(\mathrm{m}^{3} / \mathrm{s}\right)$ & $1995-2013$ & 0.7 & 6.82 & 49.9 \\
\hline Peć Mlini, niz & Protok $\left(\mathrm{m}^{3} / \mathrm{s}\right)$ & $1990-2002$ & 0.12 & 9.23 & 70.4 \\
\hline Klobuk & Protok $\left(\mathrm{m}^{3} / \mathrm{s}\right)$ & $\begin{array}{l}1990 \text { - 1991; } \\
1995 \text { - 2002; }\end{array}$ & 2.26 & 19.9 & 148.3 \\
\hline
\end{tabular}

\subsection{Konceptualni model}

\subsubsection{Generalne postavke modela}

Modeliranje procesa oborina-otjecanje je često temeljeno na konceptualno prezentaciji fizikalnog procesa u tako zvanom ,lumped“ modelu. Generalno, parametri koji se koriste u ovakvim modelima moraju biti procijenjeni i kalibrirani jer se ne mogu mjeriti na skali cijelog sustava. Prezentirani model koristi koeficijent recesije, metodu separacije hidrograma te povezuje bilancu vlage $\mathrm{u}$ tlu s bilancom podzemne vode kako bi dobio potpunu količinu podzemne vode. Model prikazan na Slici 3.1. sastoji se od dva podmodela:

prvi je model bilance vlage u tlu (soil moisture balance model - SMB model) koji simulira funkcioniranje pokrova tla i gornje zone krša tzv. epikarsta

- $\quad$ drugi model, koji se temelji na bilanci podzemne vode (groundwater bilance model GWB model), koristi dva paralelna linearna rezervoara kako bi simulirao brzu i sporu komponentu toka unutar ukupnog protoka na izvoru 


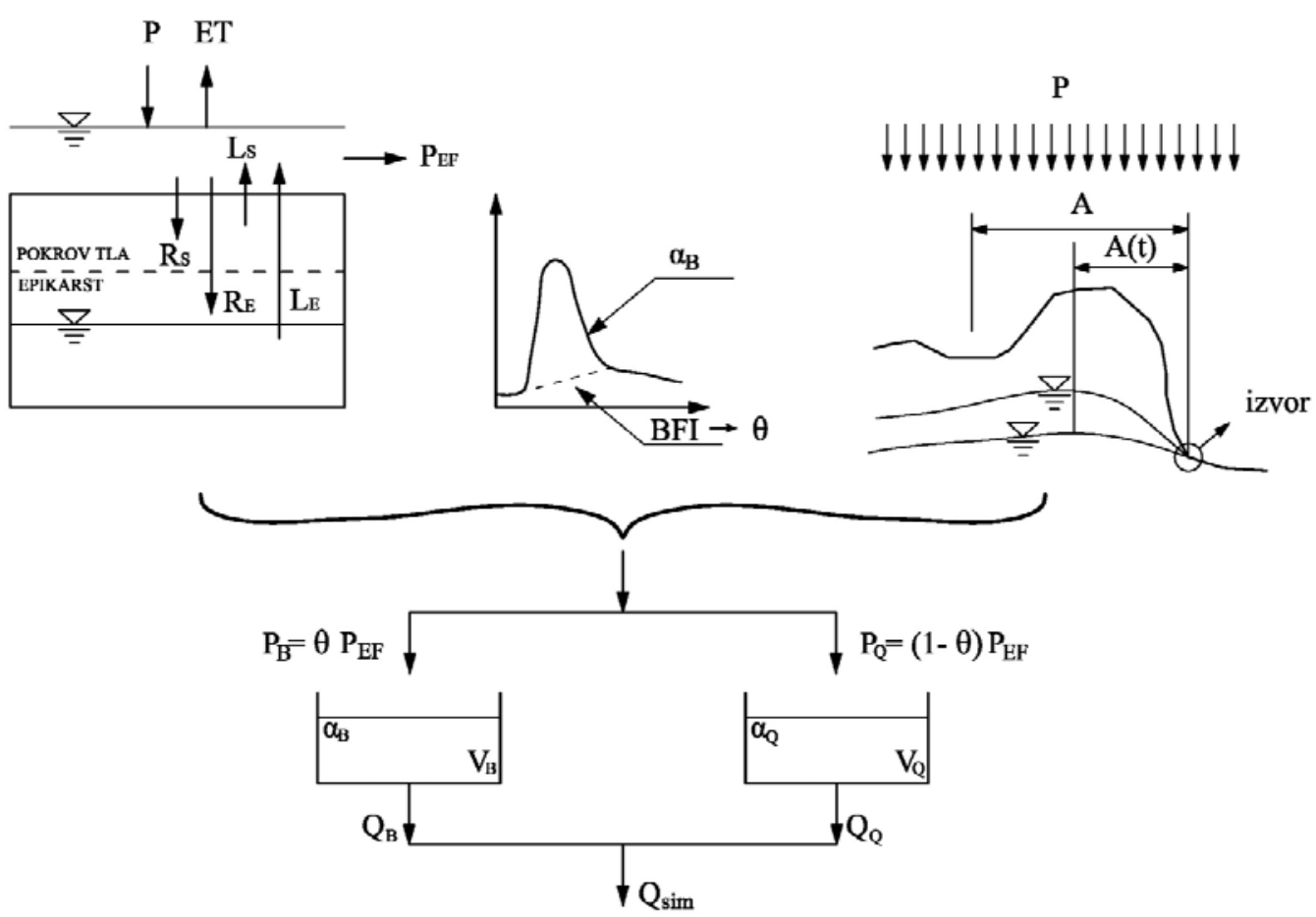

Slika 3.1. Konceptualni model

Polazišna točka za definiciju jednadžbe vodne bilance u SMB modelu je zakon očuvanja mase (Butcher et al. 2008; Hartmann et al. 2012). Palmerova metoda sa primjenom u krškim vodonosnicima korištena je za izračun efektivne oborine, maksimalnog sadržaja vlage u tlu $\left(S_{\text {Smax }}\right)$, sadržaj gornje zone krša $\left(S_{\text {Emax }}\right)$ i efektivne površine sliva. Mjesečne promjene površine sliva su uključene u proračun samo za izvor Opačac jer je pretpostavljeno postojanje alogenih promjena (Kresic i Stevanovic, 2010). Inicijalna simulacija modela pokazala je da slab utjecaj na poboljšanje rezultata (detaljnije u raspravi ovog poglavlja), stoga se za ostale izvore koristi prosječna površina sliva dobivena u kalibracijskom postupku modela.

Uz pretpostavku da je vrijeme odgovora zanemarivo u odnosu na vremenski korak $\Delta t$, vodna bilanca na krškoj površini može se izraziti u obliku kumulativnih ulaza i izlaza:

$$
E T-L_{S}-L_{E}=P-P_{E F}-R_{S}-R_{E}
$$

gdje je $P_{E F}$ efektivna oborina, $E T$ je stvarna evapotranspiracija s krške površine i podzemlja, $P$ je totalna oborina, $R_{s}$ je dotok u pokrov tla, $R_{E}$ je dotok u prostor gornje zone krša, $L_{S}$ je gubitak vlage iz pokrova tla i $L_{E}$ je gubitak vlage iz gornje zone krša. Treba primijetiti da $E T$ $L_{S^{-}} L_{E}$ predstavlja evapotranspiraciju samo sa krške površine (Jukić i Denić-Jukić, 2009). Totalni gubitak vlage iz pokrova tla i gornje zone krša iznosi: 


$$
L=L_{S}+L_{E}
$$

Jednadžba vodne bilance (3.3) je postavljena na granici tla i zraka te prema Palmeru (1965), vlaga iz pokrova tla $\left(L_{S}\right)$ je izgubljena u procesu evapotranspiracije ovisno o potencijalnoj evapotranspiraciji i totalnoj količini oborine:

$$
\begin{gathered}
L_{S}=E T_{P}-P \text { ako je } E T_{P}-P>0 \text { i } S_{S}>E T_{P}-P \\
L_{S}=S_{S} \text { ako je } E T_{P}-P>0 \text { i } S_{S}<E T_{P}-P \\
L_{S}=0 \text { ako je } E T_{P}-P<0 \text { i } S_{S}=0
\end{gathered}
$$

gdje $S_{S}$ predstavlja skladištenje vlage u tlu. Gubitak vlage u epikarstu ovisi o saturaciji (Schumann, 1993; Pandžić i sur. 2006; Jukić i Denić-Jukić, 2009):

$$
L_{E}=\left(E T_{P}-P-L_{S}\right) \frac{S_{E}}{S_{E \max }}
$$

gdje $S_{E}$ predstavlja skladištenje u gornjoj zoni krša i $S_{E m a x}$ je maksimalan kapacitet tog skladištenja. Pokrov tla i gornja zona krša su približno duboki od 80 do 320 mm (Pandžić, 1985). Pandžić je zabilježio da je jadransko obalno područje ekstremno okršeno te ima područja s gotovo potpuno stjenovitim vapnencem, tako da su dane vrijednosti grube procjene maksimalnog kapaciteta tla. Kako bi se postigao minimalan i konačan broj prepravki, Palmer i Pandžić su predložili sljedeće cjelobrojne vrijednosti - $S_{S m a x}=0,10,20$, $80(\mathrm{~mm})$ i $S_{E \max }=10,40,120,320(\mathrm{~mm})$. Totalni gubitak je zbroj gubitaka iz tla i gornje zone krša. Efektivna oborina $P_{E F}$ i totalni dotok $\left(R=R_{S}+R_{E}\right)$ ovise o $E T$, vlaga uskladištena u tlu i u pokrovu gornje zone krša $\left(S_{\max }=S_{S \max }+S_{E \max }\right)$. Ako nema $P$, posljedično nema ni dotoka $(R=0)$ ni $P_{E F}$. Ako je $E T$ negativan ali manji od $S_{\max }-S$, dotok je jednak $E T$, ali ako je ET pozitivan i veći od $S_{\max }-S, E T$ je jednak $S_{\max }-S$. Konačno, rezultati razlika u skladištenju vlage u tlu $\Delta S_{S}$ i skladištenja u gornjoj zoni krša $\Delta S_{E}$, ili $\Delta S=\Delta S_{S}+\Delta S_{E}$, za vremenski korak $\Delta t$ su izračunati putem idućeg izraza:

$$
\frac{d S}{d t}=P+L-R-E T-P_{E F}
$$

Koji predstavlja diferencijalnu jednadžbu prvog reda koja se rješava numeričkom integracijom. Koristila se eksplicitna Eulerova metoda sa zadanim inicijalnim vrijednostima što znači da je uzeta maksimalna količina vode u tlu za oba sloja. Uključivanjem vrijednosti u jednadžbu (3.8) dobije se količina vode u tlu za interval $i$ :

$$
S^{i+1}=S^{i}+\left(P^{i}+L_{S}^{i}+L_{E}^{i}-R_{S}^{i}-R_{E}^{i}-E T^{i}-P_{E F}^{i}\right) \cdot \Delta t
$$


gdje je vremenski korak jedan dan. Potencijalna evapotranspiracija - $E T_{P}$ se računa prema Eaglemanu (1976).

Nakon proračuna bilance vlage u tlu, izlazi iz modela $\left(P_{E F}\right)$ su sad ulazni podaci za model bilance podzemnih voda prezentiran $\mathrm{s}$ dva linearna rezervoara. Korištenje linearnih rezervoara omogućava transformaciju efektivne oborine $u$ hidrogram protoka (Pedersen et al. 1980). Navedena metoda se temelji na pretpostavci da se rezervoar ponaša kao vodonosnik s volumenom podzemne vode $-S_{G W}$ koji je u linearnoj vezi s protokom $Q$ :

$$
S_{G W}=K \cdot Q
$$

gdje je $Q$ protok generiran iz rezervoara, $K$ je koeficijent volumena vodonosnika - konstanta koja prezentira vrijeme potrebno za dotok podzemne vode. $K$ je recipročan koeficijentu recesije $-\alpha$. Drugim riječima, $K$ je brzina dreniranja efektivne oborine kroz vodonosnik. Razlika u volumenu rezervoara se može definirati kao jednadžba kontinuiteta (Singh, 1989) gdje je $R$ prihranjivanje rezervoara:

$$
\frac{d S_{G W}}{d t}=R-Q
$$

Linearna jednadžba prvog reda se rješava analitički s općim rješenjem:

$$
Q(t)=e^{-\alpha t}\left[C+\alpha R\left(\frac{e^{\alpha t}}{\alpha}-\frac{1}{\alpha}\right)\right]=e^{-\alpha t}\left[C+R\left(e^{\alpha t}-1\right)\right]
$$

Pojednostavljenjem izraza (3.13) i razdvajanjem komponenti brzog i sporog (baznog) toka s koeficijentom $\Theta$, simulirani protok se može iskazati jednadžbom u dva dijela:

$$
\begin{gathered}
Q_{\text {sim }, b}(t)=Q_{\text {sim }, b}(t-1) \times e^{-\alpha_{b}}+\theta \times R(t) \times\left(1-e^{-\alpha_{b}}\right) \\
\mathrm{Q}_{\text {sim }, \mathrm{q}}(\mathrm{t})=\mathrm{Q}_{\text {sim }, \mathrm{q}}(\mathrm{t}-1) \times \mathrm{e}^{-\alpha_{\mathrm{q}}}+(1-\theta) \times \mathrm{R}(\mathrm{t}) \times\left(1-\mathrm{e}^{-\alpha_{\mathrm{q}}}\right) \\
\mathrm{R}(\mathrm{t})=\mathrm{P}_{\mathrm{eff}}(\mathrm{t}) \times \mathrm{A} \\
Q_{\text {sim }}(t)=Q_{\text {sim }, b}(t)+Q_{\text {sim }, q}(t)
\end{gathered}
$$

Gdje su:

$Q_{\text {sim,b }}(t)$ - spora (bazna) komponenta otjecanja

$Q_{\text {sim, } q}(t)$ - brza komponenta otjecanja

$Q_{\text {sim }}(t)$ - ukupno otjecanje (protok) 
$\alpha_{b}$ - koeficijent recesije za bazno otjecanje (dobiven analizom hidrograma)

$\alpha_{q}-$ koeficijent recesije za brzo otjecanje (simuliran)

$\Theta$ - odnos sporog i brzog otjecanja - pretpostavlja se da je jednak indeksu baznog toka (BFI)

$Q_{\text {eff }}(t)$ - efektivna oborina (Palmerova metoda)

A ili $A(t)$ - površina otjecanja

\subsubsection{Procjena parametara}

U Tablici 3.2. prikazana je lista svih parametara koje je potrebno odrediti u procesu optimizacije uključujući njihove simbole, skraćenice, jedinice i vremensku promjenjivost. Proces procjene parametara je utemeljen na pretpostavci da se optimalne vrijednosti istih nalaze oko vrijednosti koje predstavljaju konzervativan sliv i definirane vadozne i freatske zone u kršu.

Tablica 3.2. Ulazni podaci za istraživano područje

\begin{tabular}{llll} 
Simbol & Ime & Jedinica & $\begin{array}{l}\text { Vremenski } \\
\text { promjenjiva }\end{array}$ \\
\hline$S_{\text {Smax }}$ & Pokrov tla & $\mathrm{mm}$ & $\mathrm{Ne}$ \\
$\mathrm{S}_{\mathrm{Emax}}$ & Gornja zona krša - epikarst & $\mathrm{mm}$ & $\mathrm{Ne}$ \\
$\alpha_{\mathrm{B}}$ & Koeficijent recesije za sporo otjecanje & $\mathrm{dan}^{-1}$ & $\mathrm{Ne}$ \\
$\alpha_{\mathrm{Q}}$ & Koeficijent recesije za brzo otjecanje & $\mathrm{dan}^{-1}$ & $\mathrm{Ne}$ \\
$\theta$ & Težinski koeficijent za raspodjelu & & $\mathrm{Ne}$ \\
$\mathrm{A}_{\mathrm{EFF}}$ & efektivne oborine & - & $\mathrm{Da} / \mathrm{Ne}$
\end{tabular}




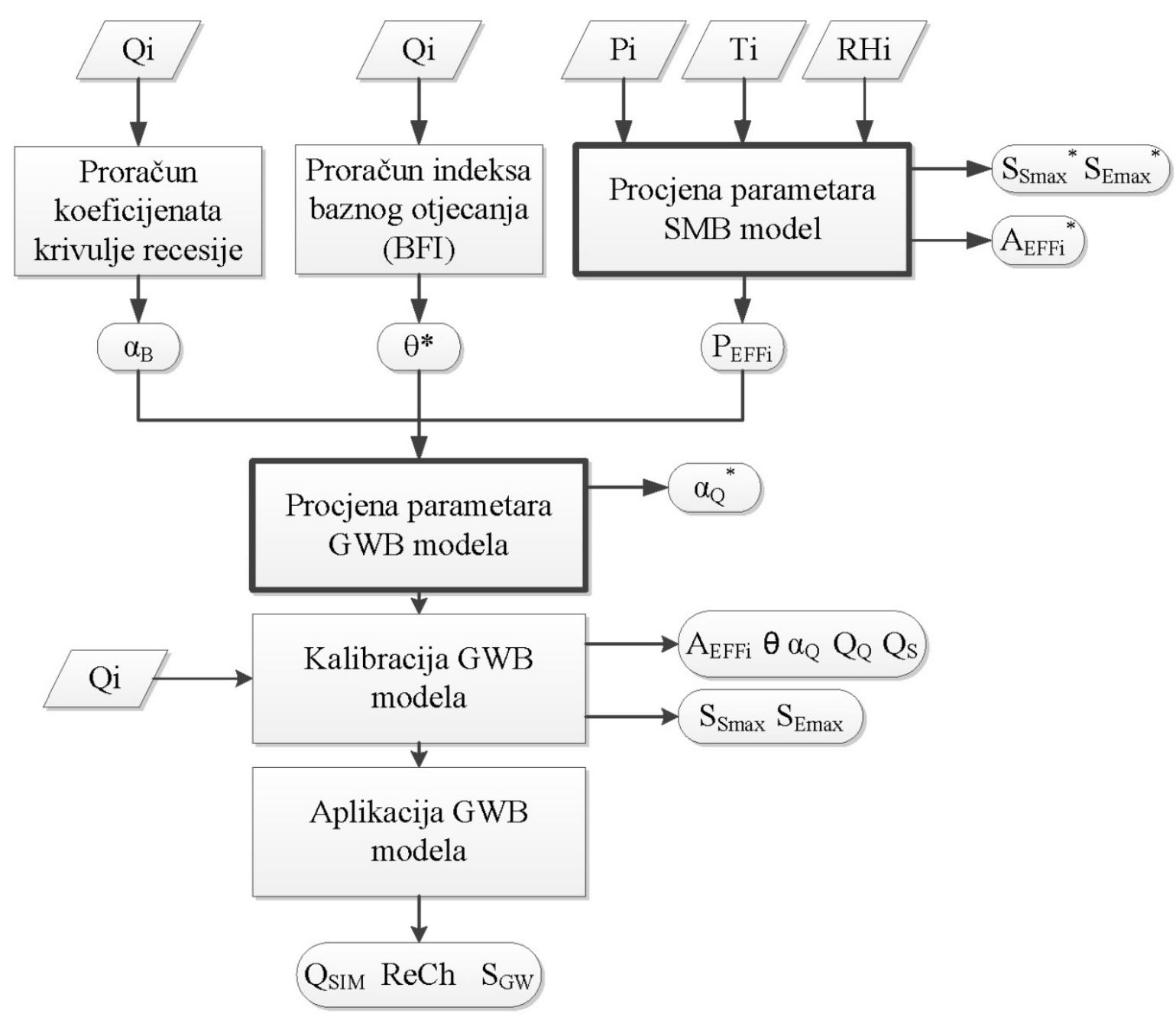

Slika 3.2. Dijagram toka procjene parametara i procedure transformacije ulaznih podataka. Oznake: $Q i$ - izmjereni protok, $P i$ - padaline, $T i$ - temperature, $R H i$ - relativna vlažnost, $P_{E F F i}$ - efektivne oborine, $A_{E F F i}$ - efektivna površina sliva, $S_{S m a x} S_{E m a x}$ - maksimalni kapacitet vlage u tlu za pokrov (S) i epikarst (E), $\alpha_{B}$ - koef. recesije sporog otjecanja, $\alpha_{Q}-$ koef. recesije brzog otjecanja, $\theta$ - težinski koeficijent za raspodjelu efektivne oborine, $Q_{Q}$ komponenta brzog toka, $Q_{B}-$ komponenta sporog toka, $Q_{S I M}$ - ukupni simulirani tok, $R e C h$ - punjenje akvifera and $S_{G W}$ - volumen vode krškog rezervoara. * označava inicijalne vrijednosti 
Dijagram toka prikazan na Slici 3.2. prezentira osnovne korake u procjeni parametara i proračunu s inicijalnim vrijednostima naznačenim zvjezdicom. Algoritam modela počinje predobradom hidrograma putem čega se dobiju recesijski koeficijent $\alpha_{b}$ i faktor $\Theta$. Klimatološki ulazi (dnevna oborina $P_{i}$, prosječna temperatura $T_{i}$ i relativna vlažnost $R H_{i}$ ) i jednadžba vodne bilance su korišteni za određivanje efektivne oborine koja je glavni ulazni podatak za pod-model bilance podzemne vode. Nakon procjene inicijalnih vrijednosti koeficijenta brzog otjecanja, kalibracija se vrši korištenjem više statističkih mjera u cilju efikasnog umanjenja razlike između simuliranih i mjerenih vrijednosti protoka na izvoru. Nakon kalibracije, model bilance podzemne vode (GWB) izračunava dotok podzemne vode $\mathrm{i}$ uskladištenje ( $\mathrm{ReCh}$ i $\mathrm{S}_{\mathrm{GW}}$ na Slici 3.2.). Ključni parametri modela su objašnjeni dalje u tekstu.

Indeks baznog (sporog) toka (Base flow indeks - BFI)

Prilikom procjene bilance podzemne vode kritično je razumijevanje doprinosa iste ka tečenju u potocima. Analize hidrograma potoka, posebno odvajanje i interpretacija baznog otjecanja (dugoročni tok $\mathrm{s}$ kašnjenjem iz uskladištenja) i brzog otjecanja (kratkoročni odgovor na oborinu), se smatra dobro utvrđenom strategijom u razumijevanju magnitude i dinamike otjecanja podzemne vode (Brodie et al. 2005). Analiziranje bazne komponente u hidrogramu otjecanja ima dugačku povijest razvoja još od ranih teoretskih i empirijskih radova Boussinesqa (1904), Mailleta (1905) i Hortona (1933). Brojne razvijene metode se prigodno mogu razvrstati u tri osnovna pristupa:

- separacija baznog otjecanja

- analiza učestalosti

- analiza recesije.

U promatranom području istraživanja korištene su i međusobno uspoređene separacija baznog otjecanja i analiza učestalosti. Separacija baznog otjecanja (Hisdal i sur., 2004; Brušková 2008) ima jedinstveno rješenje dok analiza učestalosti (Nathan i McMahon, 1990; Eckhardt, 2005) upućuje na potrebu za boljim prethodnim poznavanjem područja i njegovih karakteristika. Analiza učestalosti je testirana na promatranom području ali nedostatak prethodnog znanja o sustavu je dao dvosmislene rezultate, stoga se grafo-analitički pristup s jedinstvenim rješenjem pokazao prikladnijim. BFI iz separacije baznog otjecanja razvijen je tijekom istraživanja malih protoka u Velikoj Britaniji. Indeks prezentira odnos baznog otjecanja i ukupnog otjecanja izračunatog tzv. zaglađivanjem hidrograma (eng. smoothing) i procesom separacije korištenjem dnevnih protoka. BFI je time uzet kao mjera riječnog 
otjecanja koje je došlo od uskladištenih resursa te, kao generalni opis sliva, je našao brojna područja primjene uključujući procjenu malih tokova i dotjecanje podzemnih voda. Proces separacije započinje pronalaskom petodnevnih minimuma protoka $\mathrm{u}$ nepreklapajućim uzastopnim periodima, te potom traženjem prijelomnih točaka u tom nizu pomoću linearne interpolacije. Prijelomne točke, definirane kao točke koje pripadaju liniji separacije baznog otjecanja, su povezane kako bi se dobio hidrogram baznog otjecanja. Rezultati separacije baznog otjecanja su prikazani na Slikama 3.3. - 3.6. Idući korak je proračun volumena vode ispod hidrograma baznog otjecanja $\left(V_{\text {bazno }}\right)$ i pripadajućeg ukupnog volumena $\left(V_{\text {ukupno}}\right)$. Izračun BFI ( $\left.V_{\text {bazno }} / V_{\text {ukupno}}\right)$ se radi za specifični vremenski period, uobičajeno sezonski ili godišnji BFI. Proračun je za izvore Opačac i Tihaljina (VS Peć Mlini,niz) napravljen za najduži period promatranja bez prekida. Isto nije bilo moguće napraviti za izvore Grudsko vrelo i Klokun stoga su iskorišteni svi postojeći podaci te prikazani na istoj slici uz oznaku prekida u nizu. Prosječni višegodišnji indeks baznog toka iznosi za Grudsko vrelo $=0.77$, Opačac $=0.65$, Tihaljina $=0.63$, Klokun $=0.65$. Zanimljivo je primijetiti da metoda daje najveće vrijednosti kod izvora Grudsko vrelo. Zapravo, ocjena parametra BFI je nezahvalna za ovakav slučaj jer se u potpunosti ne zna da li postoji i kakvog je tipa tečenje unutar vodonosnika kada ovaj izvor presuši. 
$\mathrm{Q}\left(\mathrm{m}^{3} / \mathrm{s}\right)$

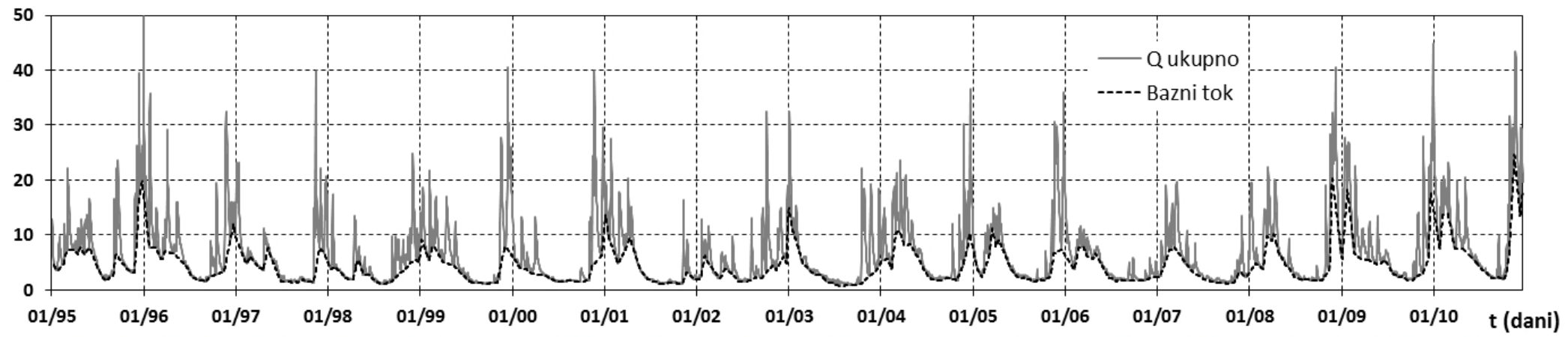

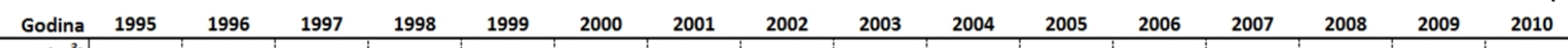

\begin{tabular}{l|l|l|l|l|l|l|l|l|l|l|l|l|l|l|l|l|l|l|l|l|l|l|l}
\hline $\mathrm{V}$ total $\left(\mathrm{m}^{3}\right)$ & $9.62 \mathrm{E}+10$ & $1.02 \mathrm{E}+11$ & $7.09 \mathrm{E}+10$ & $5.48 \mathrm{E}+10$ & $8.16 \mathrm{E}+10$ & $6.17 \mathrm{E}+10$ & $6.62 \mathrm{E}+10$ & $6.03 \mathrm{E}+10$ & $6.10 \mathrm{E}+10$ & $9.21 \mathrm{E}+10$ & $7.81 \mathrm{E}+10$ & $5.85 \mathrm{E}+10$ & $5.63 \mathrm{E}+10$ & $9.15 \mathrm{E}+10$ & $9.37 \mathrm{E}+10$ & $1.33 \mathrm{E}+11$ \\
\hline
\end{tabular}

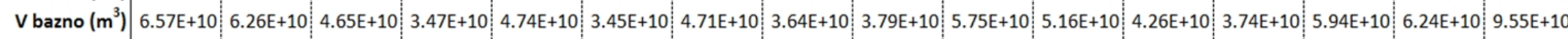

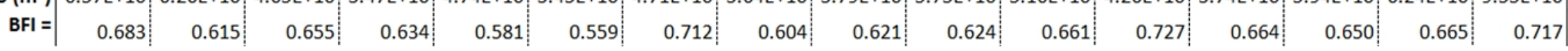

Slika 3.3. Proračun koeficijenta baznog otjecanja za izvor Opačac. Period 1995 - 2010 godina

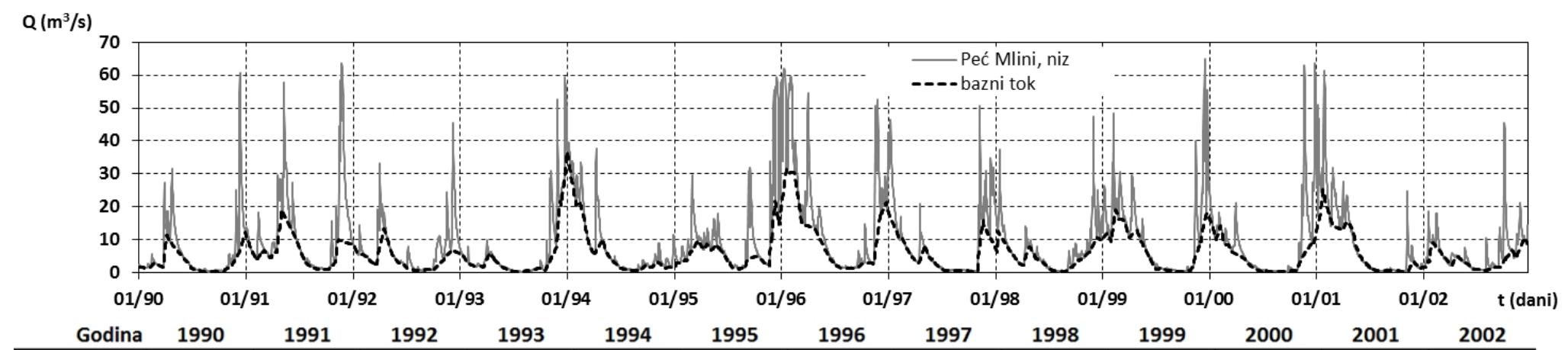

\begin{tabular}{l|c|c|c|c|c|c|c|c|c|c|c|c|c|}
\hline V total $\left(\mathbf{m}^{3}\right)$ & $6.698 \mathrm{E}+10$ & $1.390 \mathrm{E}+11$ & $6.843 \mathrm{E}+10$ & $6.843 \mathrm{E}+10$ & $1.050 \mathrm{E}+11$ & $1.176 \mathrm{E}+11$ & $2.012 \mathrm{E}+11$ & $1.012 \mathrm{E}+11$ & $8.182 \mathrm{E}+10$ & $1.289 \mathrm{E}+11$ & $9.153 \mathrm{E}+10$ & $1.233 \mathrm{E}+11$ & $7.098 \mathrm{E}+10$ \\
\hline
\end{tabular}

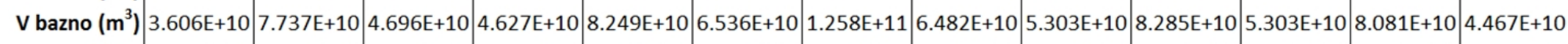
$\mathrm{BFI}=$
$0.538 \quad 0.556$
$0.686 \mid 0.676$
$0.785 \mid 0.556$
$0.626 \quad 0.640$
$0.648|\quad 0.643| 0.579$
$0.656 \quad 0.629$

Slika 3.4. Proračun koeficijenta baznog otjecanja za VS Peć Mlini nizvodno (izvor Tihaljina) Period 1990 - 2002 godina 
$Q\left(m^{3} / s\right)$

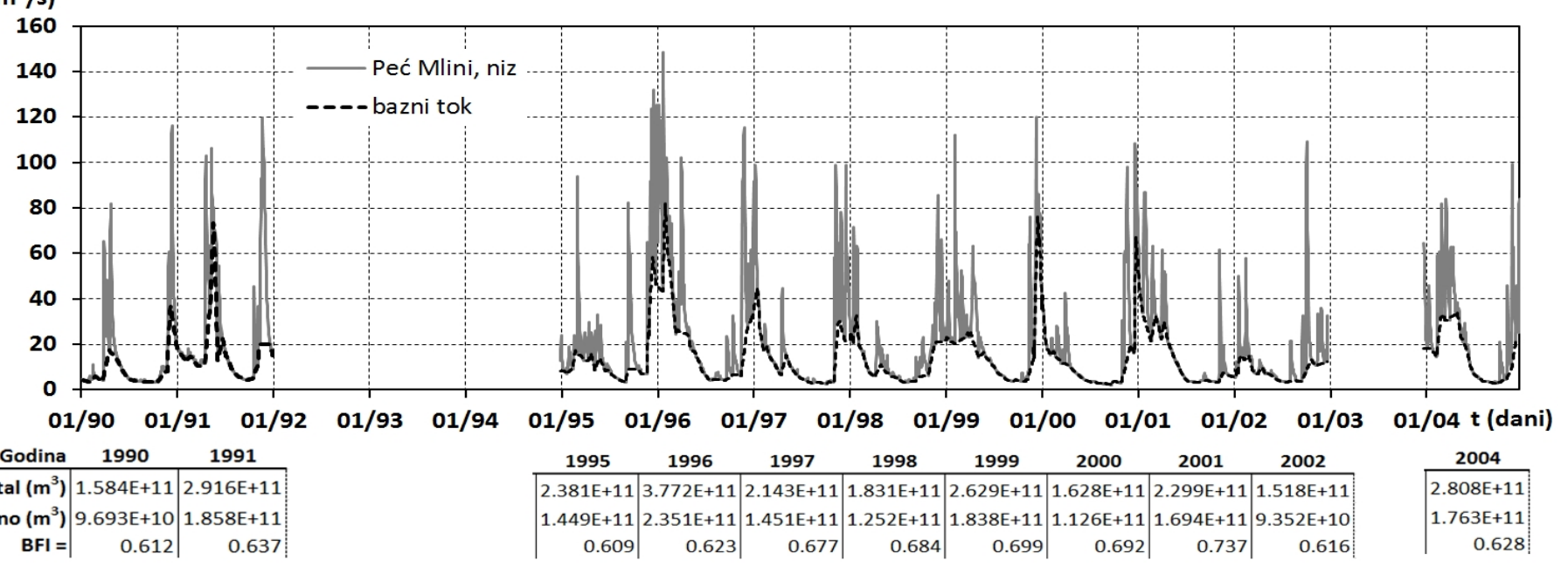

Slika 3.5. Proračun koeficijenta baznog otjecanja za VS Klobuk nizvodno (izvor Klokun) Period 1990-1991; 1995-2002;2004

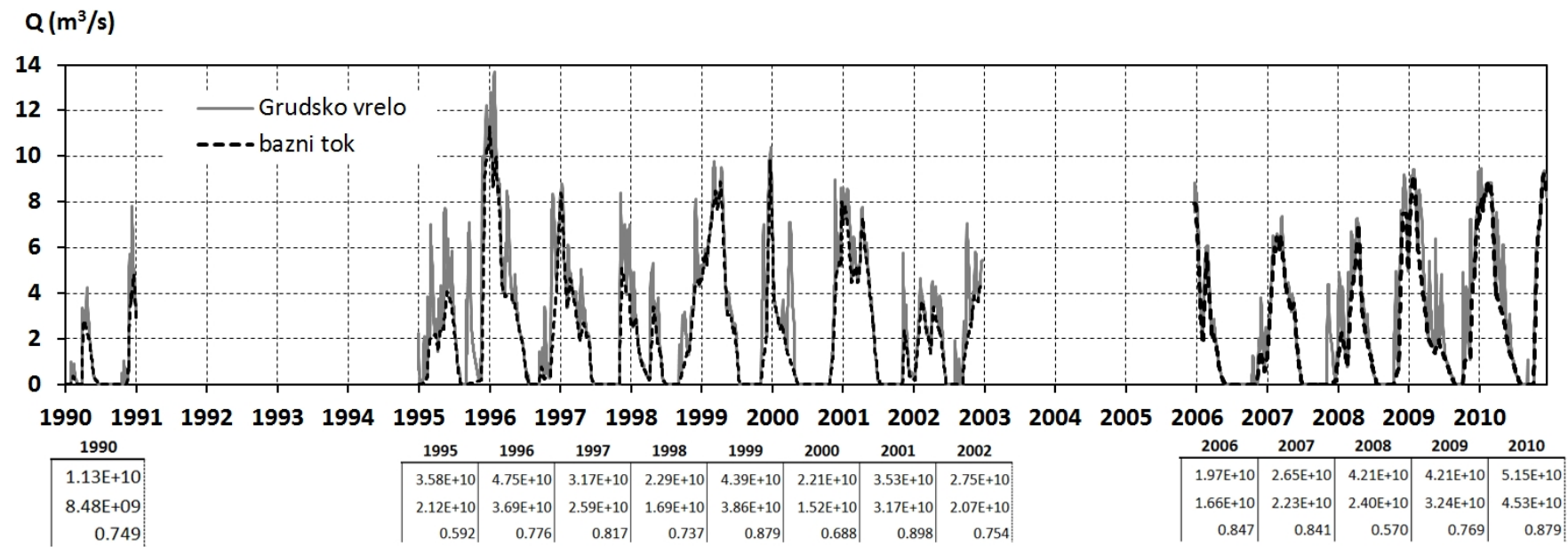

Slika 3.6. Proračun koeficijenta baznog otjecanja za VS Grudsko vrelo. Period 1990-1991; 1995-2002;2004 


\section{Glavni koeficijent recesije}

Druga krucijalna komponenta hidrološkog istraživanja i procjene podzemne vode je recesijska komponenta hidrograma budući da njezin oblik značajno ovisi o hidrogeološkim karakteristikama promatranog vodonosnika i njena matematička identifikacija omogućuje predviđanje smanjenje dotoka u sušnim razdobljima. Kako bi iskazao vrijednosti recesijske krivulje, Boussinesq (1904) je koristio nelinearnu parcijalnu diferencijalnu jednadžbu za nestacionarno filtracijsko tečenje $\mathrm{s}$ neograničenim vodnim licem $\mathrm{u}$ anizotropnim vodonosnicima:

$$
Q=Q_{0} e^{-\alpha(t-t 0)}
$$

gdje je $Q_{0}$ protok na početku recesije (u trenutku $t_{0}$ ), $Q$ je protok u vremenu $t$ i $\alpha$ je koeficijent recesije. Struktura jednadžbe jasno ukazuje da je koeficijent recesije esencijalan u utvrđivanju recesijskog protoka. Mnogi znanstvenici su pokušali pojednostavniti izraz (3.18). Petras (1986) je koristio grafičku metodu na polu-logaritamskom mjerilu koja prikazuje recesijsku krivulju kao pravac gdje je $\alpha$ koeficijent smjera. Heterogeni vodonosnik je naznačen kao zakrivljena linija kad je prikazan na polu-logaritamskom mjerilu, te u takvom slučaju $\alpha$ nije konstanta nego funkcija vremena. Parametri $Q_{0 i}$ i $\alpha_{i}$ su dobiveni separacijom donjeg i gornjeg dijela krivulje te se takvim preklapanjem cijela krivulja može iskazati kao niz ravnih linija. Protok $Q$ u trenutku $t$ se može izračunati iz jednadžbe analitičke recesijske krivulje:

$$
Q=Q_{01} e^{-\alpha_{1} t}+Q_{02} e^{-\alpha_{2} t}+\cdots+Q_{0 n} e^{-\alpha_{n} t}
$$

gdje $Q_{0 i}$ i $\alpha_{i}$ odgovaraju $i$-toj liniji unutar niza ravnih linija. Krivulje su grafički prikazane u polu-logaritamskom koordinatnom sustavu i matematički iskazane prema jednadžbi:

$$
Q=Q_{01} e^{-\alpha_{1 j} t}+Q_{02} e^{-\alpha_{2 j} t}+\cdots+Q_{0 n} e^{-\alpha_{n j} t}
$$

gdje $(j=I, I I, \ldots, N)$ predstavljaju vrijednost $j$-te krivulje. Broj krivulja ovisi o broju pojavljivanja neporemećenih perioda tijekom promatranja. Jednadžba glavne recesijske krivulje se dobije osrednjavanjem osnovnih parametara $Q_{0 i j}$ i $\alpha_{i j}$, i njezin oblik je:

$$
\bar{Q}=\bar{Q}_{01} e^{-\overline{\alpha_{1}} t}+\bar{Q}_{02} e^{-\overline{\alpha_{2}} 2 t}+\cdots+\bar{Q}_{0 n} e^{-\overline{\alpha_{n}} t}
$$

gdje za srednje početne vrijednosti vrijedi:

$$
\bar{Q}_{01}=\frac{1}{N} \sum_{j=1}^{N} Q_{01 j} ; \bar{Q}_{02}=\frac{1}{N} \sum_{j=1}^{N} Q_{02 j} ; \ldots ; \bar{Q}_{0 n}=\frac{1}{N} \sum_{j=1}^{N} Q_{0 n j}
$$


pa su prema tome srednji koeficijenti otjecanja dobiveni kao:

$$
\bar{\alpha}_{1}=\frac{1}{N} \sum_{j=1}^{N} \alpha_{1 j} ; \bar{\alpha}_{2}=\frac{1}{N} \sum_{j=1}^{N} \alpha_{2 j} ; \ldots ; \bar{\alpha}_{n}=\frac{1}{N} \sum_{j=1}^{N} \alpha_{n j}
$$

Na Slikama 3.7. - 3.10. prikazane su srednje anvelope recesijske krivulje iz pripadajućih 4 identificiranih krivulja za izvor Grudsko vrelo, 18 za Opačac, 6 za Tihaljinu i 5 za Klokun. Glavna recesijska krivulja je naznačena podebljanom crvenom linijom a produljene recesijske anvelope su osjenčane sivo. Srednje vrijednosti glavnih koeficijenata recesije su korištene kao početne vrijednosti za konceptualni model. Korištena je superponirana jednadžba (3.19) s prva dva člana $Q_{01} e^{-\alpha 1 j t}$ i $Q_{02} e^{-\alpha 2 j t}$ gdje $\alpha_{1}$ predstavlja nagib baznog otjecanja recesijske krivulje, a $\alpha_{2}$ se može interpretirati kao recesijski koeficijent brze komponente od ukupnog toka. Ova dva koeficijenta se uzimaju kao najbolje dostupne aproksimacije za $\alpha_{b}$ i $\alpha_{q}$. Iako obje vrijednosti dobro prezentiraju sustav, obavljena je kalibracija na koeficijentu brzog otjecanja kako bi se testirala njegova osjetljivost na ukupni učinak konceptualnog modela.

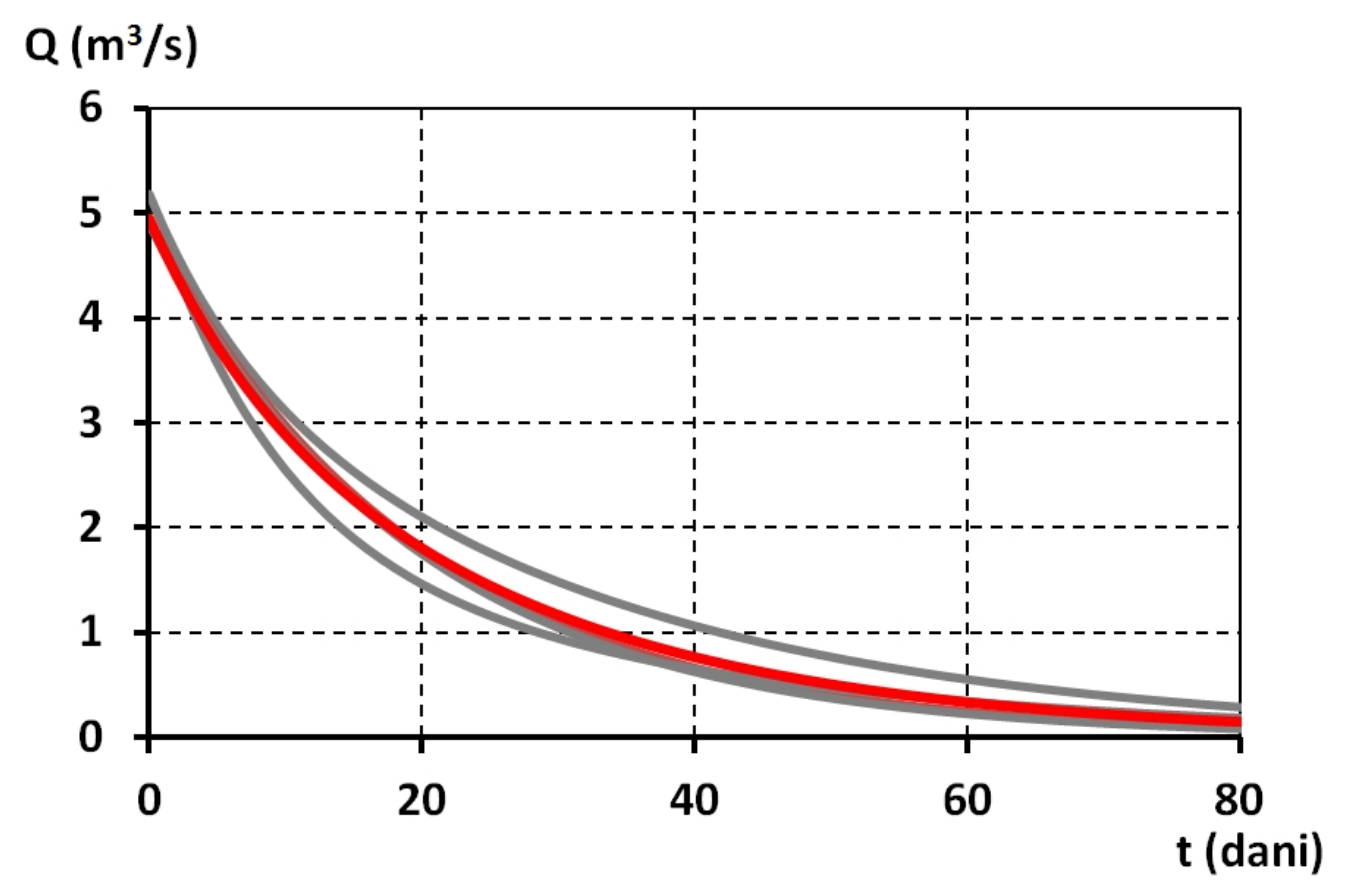

Slika 3.7. Anvelopa krivulje recesije za izvor Grudsko vrelo 


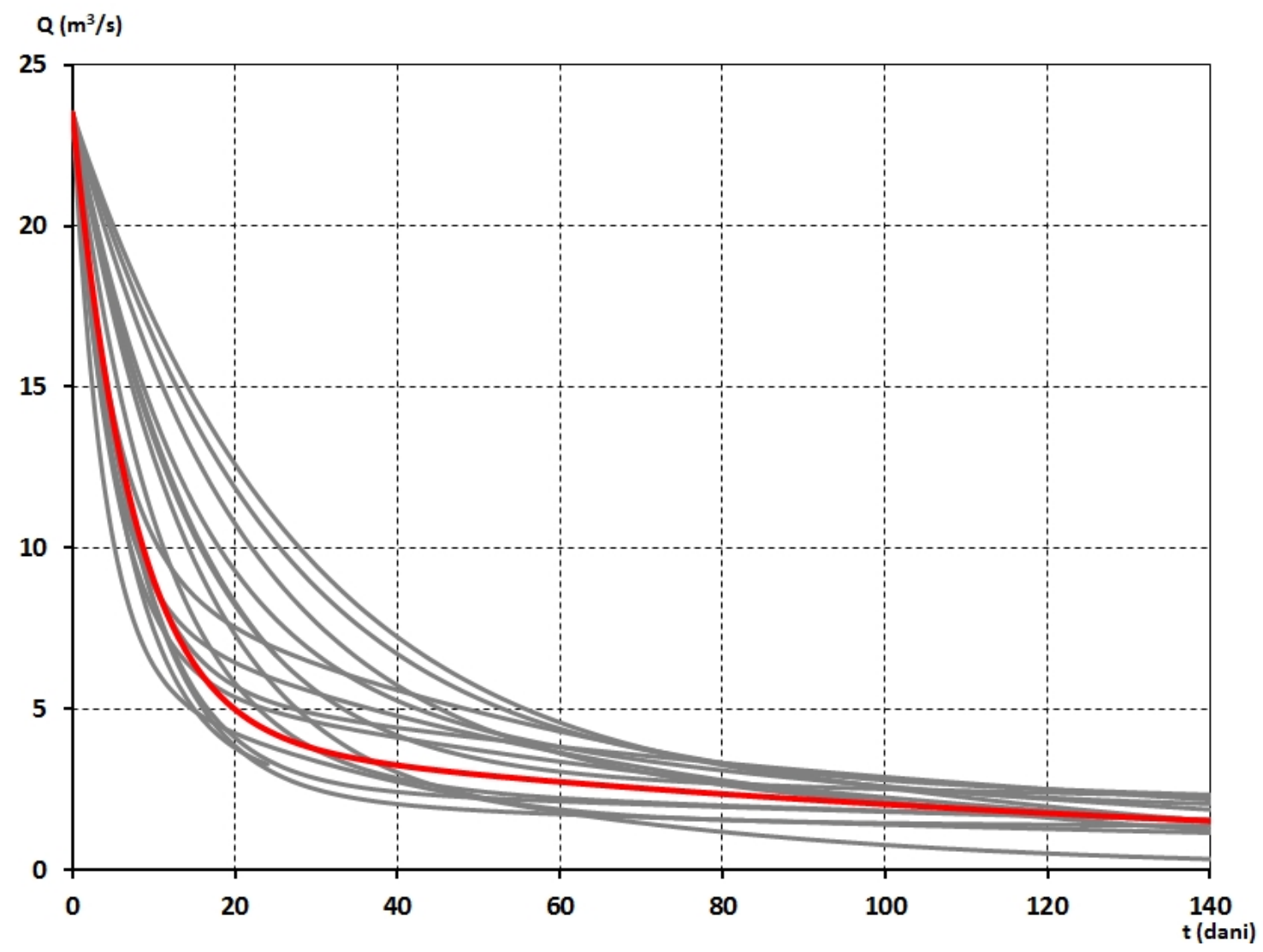

Slika 3.8. Anvelopa krivulje recesije za izvor Opačac

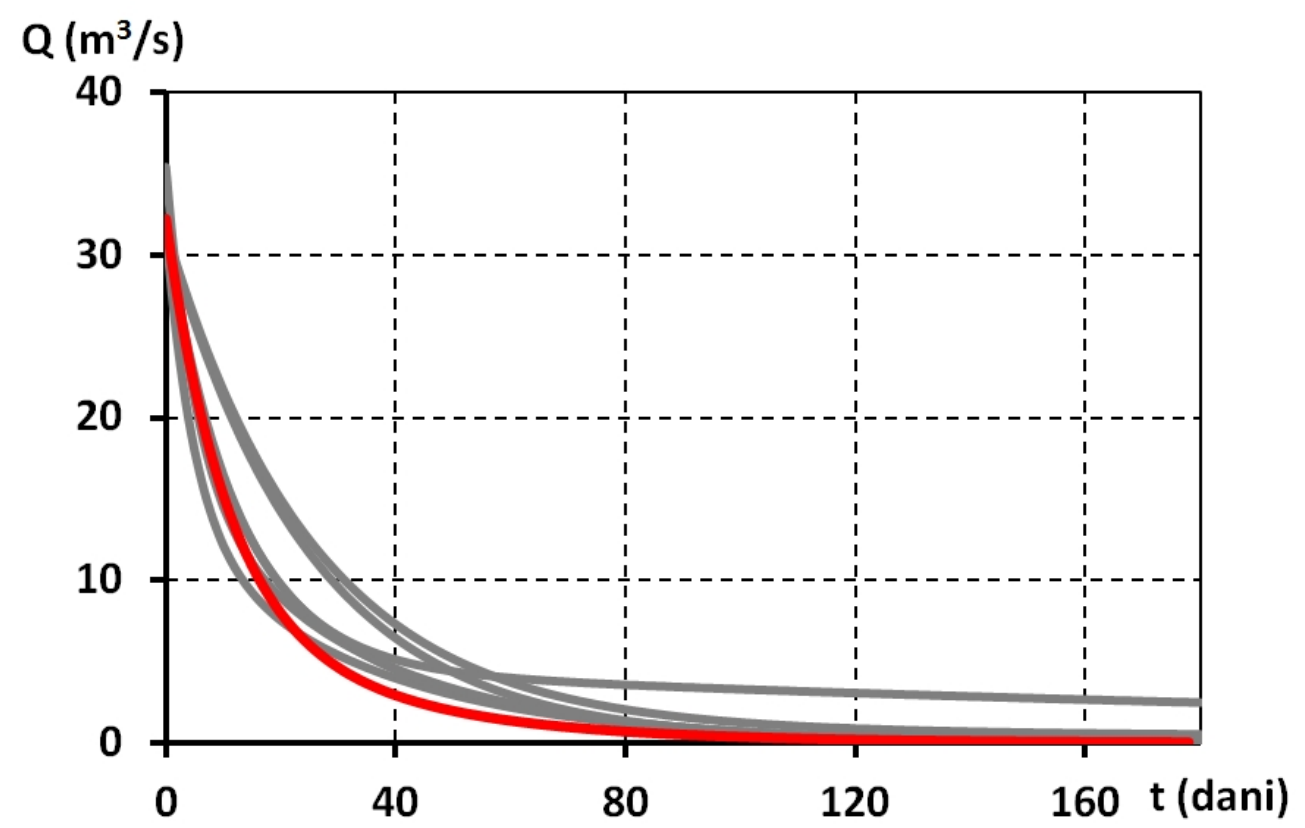

Slika 3.9. Anvelopa krivulje recesije za izvor Tihaljina 


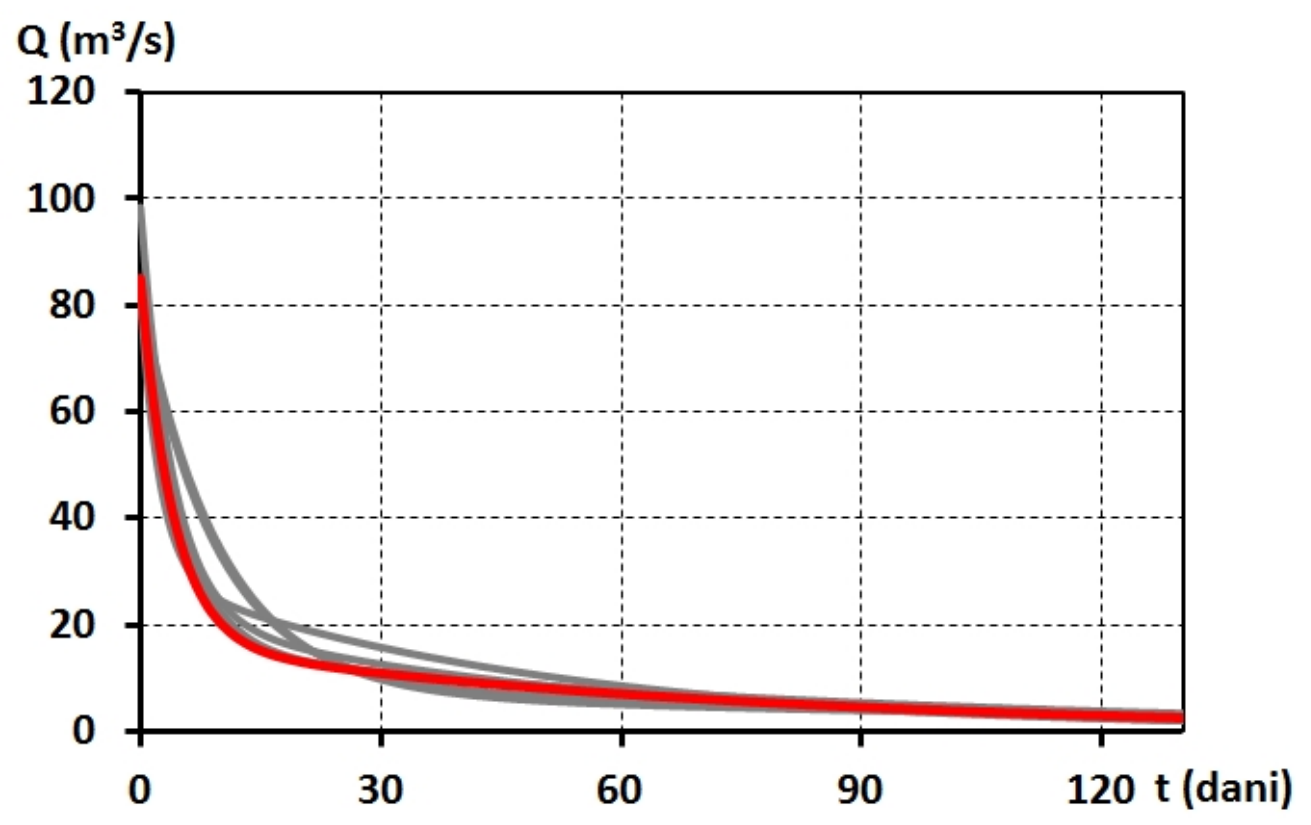

Slika 3.10. Anvelopa krivulje recesije za izvor Klokun

Osnovni parametri krivulja recesije su prikazani u Tablicama 3.3. - 3.7. Izvor Grudsko vrelo prilikom prilagodbe eksponencijalne krivulje na recesijski dio otjecanja pokazuje dvojako ponašanje. Ukoliko se za recesije iz 2006. i 2008. godine odaberu dva koeficijenta za opisivanje krivulje, analitičko rješenje daje lošiju prilagodbu $\left(\mathrm{R}^{2}=0.92\right.$ naspram $\left.\mathrm{R}^{2}=0.98\right)$. Općenito je teško utvrditi točno ponašanje recesije na temelju 4 uočene recesije relativno kratkog vremena trajanja - prosječno 70 dana. S druge strane polja, izvor Opačac pokazuje duži srednji recesijski period - oko 127 dana što je karakteristika vodonosnika sa sporim otjecanjem. Srednja vrijednost $\alpha_{1}$ i $\alpha_{2}$ su 0.007 i 0.13 . $\alpha_{2}$ utječe na linearno ponašanje u prvih 20 dana recesijske anvelope zbog većih vrijednosti od $\alpha_{1}$. Nizvodno, izvor Tihaljina pokazuje slične karakteristike sa izvorom Opačac u prvom dijelu krivulje recesije opisanom koeficijentom $\alpha_{2}$ - za Opačac on je u rasponu $0.04-0.3$ i a Tihaljinu $0.03-0.2$. Iako su vrijednosti $\alpha_{1}$ nešto niže za Opačac $(0.001-0.01$; Tihaljina $0.003-0.1)$ prema Malik i Vojtkova (2012) stupnju karstifikacije oba izvora su u istoj kategoriji akvifera sa nepravilnom mrežom pukotina i prevladavajućim manjim i mikro pukotinskim sistemom. U nekim slučajevima pojavljuju se kratki turbulentni tokovi u ovakvom tipu stijenskog okruženja - što i jest slučaj kod Tihaljine (ponor Šajnovac), a vjerojatno i kod Opačca (testovi bojanja). Visoke vrijednosti $\alpha_{2}$ izvora Klokun mogu naznačivati zonu zasjeka sa gustom mrežom pukotina i češćim slučajevima freatičnog sistema provodnika. 
Tablica 3.4. Osnovni parametri recesijske krivulje za izvor Opačac - $\mathrm{Q}_{0}$ i $\mathrm{Q}_{1}$ označavaju prvu i zadnju vrijednost recesijskog perioda. $\mathrm{Q}_{0}$ i $\mathrm{Q}_{1}$ su vrijednosti dobivene konstrukcijom pravaca u polu-logaritamskom mjerilu. Simbol a označava vremenski interval između novog inicijalnog protoka, dobivenog ekstrapolacijom. Q' ${ }_{01} \mathrm{i}$ Q' ${ }_{02}$ su vrijednosti pomaknute za vremenski interval a u ishodište koordinatnog sistema anvelope.

\begin{tabular}{|c|c|c|c|c|c|c|c|c|c|c|c|}
\hline PERIOD & $Q_{0}\left(m^{3} / s\right)$ & $Q_{1}\left(m^{3} / s\right)$ & $Q_{01}\left(m^{3} / s\right)$ & $t_{1}$ (dani) & $Q_{02}\left(m^{3} / s\right)$ & $\alpha_{1}$ & $\alpha_{2}$ & a (dani) & $Q_{01}^{\prime}\left(\mathrm{m}^{3} / \mathrm{s}\right)$ & $Q_{02}^{\prime}\left(m^{3} / s\right)$ & $\mathrm{t}_{1}{ }^{\prime}$ (dani) \\
\hline 01.06.-03.09.1995 & 16.50 & 2.69 & 3.00 & 95 & 13.50 & 0.0020 & 0.0676 & 6.2 & 3.04 & 20.46 & 101.2 \\
\hline 21.09.-26.11.1995 & 23.50 & 3.48 & 6.12 & 66 & 17.38 & 0.0100 & 0.1954 & 0.0 & 6.12 & 17.38 & 66.0 \\
\hline 14.05.-10.09.1996 & 15.90 & 2.10 & 3.70 & 119 & 12.20 & 0.0070 & 0.0491 & 9.6 & 3.95 & 19.55 & 128.6 \\
\hline 17.10.-17.11.1996 & 19.50 & 3.34 & 6.20 & 31 & 13.30 & 0.0210 & 0.2658 & 1.0 & 6.33 & 17.17 & 32.0 \\
\hline 23.04.-05.11.1997 & 10.40 & 1.27 & 2.13 & 196 & 8.27 & 0.0010 & 0.0356 & 26.6 & 2.19 & 21.31 & 222.6 \\
\hline 25.03.-22.10.1999 & 12.50 & 1.32 & 1.55 & 152 & 10.95 & 0.0010 & 0.0668 & 10.4 & 1.57 & 21.93 & 162.4 \\
\hline 06.04.-29.09.2000 & 13.30 & 1.45 & 2.65 & 152 & 10.65 & 0.0040 & 0.0923 & 7.2 & 2.73 & 20.77 & 159.2 \\
\hline 22.04.-10.11.2001 & 15.10 & 1.12 & 2.66 & 202 & 12.44 & 0.0040 & 0.0640 & 8.0 & 2.75 & 20.75 & 210.0 \\
\hline 23.02.-09.04.2002 & 11.70 & 2.03 & 4.46 & 45 & 7.24 & 0.0180 & 0.1842 & 5.1 & 4.89 & 18.61 & 50.1 \\
\hline 29.05.-07.08.2002 & 9.85 & 1.66 & 2.22 & 70 & 7.63 & 0.0050 & 0.1246 & 8.2 & 2.32 & 21.18 & 78.2 \\
\hline 06.02.-21.10.2003 & 15.30 & 4.91 & 5.66 & 257 & 9.64 & 0.0070 & 0.1645 & 3.7 & 5.81 & 17.69 & 260.7 \\
\hline 10.05.-16.10.2004 & 12.60 & 3.62 & 2.89 & 159 & 9.71 & 0.0020 & 0.0413 & 18.1 & 3.00 & 20.50 & 177.1 \\
\hline 22.04.-12.09.2005 & 15.80 & 1.57 & 5.39 & 143 & 10.41 & 0.0080 & 0.0699 & 7.7 & 5.73 & 17.77 & 150.7 \\
\hline 06.10.-20.11.2006 & 5.79 & 1.64 & 2.23 & 45 & 3.56 & 0.0060 & 0.2912 & 6.1 & 2.31 & 21.19 & 51.1 \\
\hline 08.06.-26.10.2007 & 8.61 & 1.46 & 2.59 & 140 & 6.02 & 0.0040 & 0.1279 & 9.7 & 2.69 & 20.81 & 149.7 \\
\hline 24.04.-12.06.2008 & 19.70 & 4.29 & 8.07 & 49 & 11.63 & 0.0135 & 0.2227 & 1.2 & 8.20 & 15.30 & 50.2 \\
\hline 15.06.-29.09.2008 & 9.29 & 1.69 & 2.96 & 106 & 6.33 & 0.0050 & 0.1508 & 7.8 & 3.08 & 20.42 & 113.8 \\
\hline 15.07.-18.09.2010 & 20.40 & 2.08 & 9.23 & 124 & 11.17 & 0.0130 & 0.1925 & 1.2 & 9.38 & 14.12 & 125.2 \\
\hline
\end{tabular}

Glavna krivulja $\phi \quad 23.5$ 
Tablica 3.5. Osnovni parametri recesijske krivulje za izvor Grudsko vrelo

\begin{tabular}{|c|c|c|c|c|c|c|c|c|c|c|c|}
\hline PERIOD & $Q_{0}\left(m^{3} / s\right)$ & $Q_{1}\left(m^{3} / s\right)$ & $Q_{01}\left(\mathrm{~m}^{3} / \mathrm{s}\right)$ & $t_{1}$ (dani) & $Q_{02}\left(\mathrm{~m}^{3} / \mathrm{s}\right)$ & $\alpha_{1}$ & $\alpha_{2}$ & a (dani) & $Q_{01}^{\prime}\left(m^{3} / \mathrm{s}\right)$ & $Q_{02}^{\prime}\left(m^{3} / s\right)$ & $\mathrm{t}_{1}{ }_{1}$ (dani) \\
\hline 21.01. - 14.04.1998 & 4.90 & 0.27 & 1.27 & 84 & 3.91 & 0.0326 & 0.1479 & 0.0 & 1.27 & 3.91 & 84.0 \\
\hline 13.04. - 17.06.2006 & 2.79 & 0.00 & 0.00 & 66 & 3.09 & 0.0500 & 0.0000 & 9.3 & 0.00 & 4.90 & 75.3 \\
\hline 15.06. - 01.08.2008 & 3.10 & 0.10 & 0.00 & 48 & 2.99 & 0.0515 & 0.0000 & 9.6 & 0.00 & 4.90 & 57.6 \\
\hline 02.07. - 02.09.2009 & 4.85 & 0.32 & 3.18 & 63 & 2.07 & 0.0303 & 0.1122 & -1.1 & 2.80 & 2.01 & 61.9 \\
\hline
\end{tabular}

Tablica 3.6. Osnovni parametri recesijske krivulje za izvor Tihaljina

PERIOD $\quad Q_{0}\left(\mathrm{~m}^{3} / \mathrm{s}\right) \mathrm{Q}_{1}\left(\mathrm{~m}^{3} / \mathrm{s}\right) \mathrm{Q}_{01}\left(\mathrm{~m}^{3} / \mathrm{s}\right) \mathrm{t}_{1}$ (dani) $Q_{02}\left(\mathrm{~m}^{3} / \mathrm{s}\right)$

\begin{tabular}{|c|c|c|c|c|c|c|c|c|c|c|c|}
\hline PERIOD & $Q_{0}\left(m^{3} / s\right)$ & $Q_{1}\left(m^{3} / s\right)$ & $Q_{01}\left(m^{3} / s\right)$ & $t_{1}$ (dani) & $Q_{02}\left(m^{3} / s\right)$ & $\alpha_{1}$ & $\alpha_{2}$ & a (dani) & $Q_{01}^{\prime}\left(m^{3} / \mathrm{s}\right)$ & $Q_{02}^{\prime}\left(m^{3} / s\right)$ & $\mathrm{t}^{\prime}{ }_{1}$ (dani) \\
\hline 24.04. - 20.10.1990 & 31.60 & 0.76 & 19.54 & 180 & 15.89 & 0.0312 & 0.1900 & 0.0 & 19.54 & 15.89 & 180.0 \\
\hline 16.04. - 03.08.1993 & 6.24 & 0.20 & 6.07 & 110 & 0.76 & 0.1100 & 0.0300 & 28.4 & 14.24 & 17.36 & 138.4 \\
\hline 14.05. - 20.06.1996 & 19.70 & 1.30 & 20.37 & 130 & 0.27 & 0.0129 & 0.0402 & 10.7 & 31.29 & 0.31 & 140.7 \\
\hline 23.04. - 06.11.1997 & 20.90 & 0.51 & 14.57 & 198 & 0.77 & 0.0028 & 0.0386 & 19.4 & 30.79 & 0.81 & 217.4 \\
\hline 06.04. - 01.10.2000 & 21.30 & 0.31 & 11.51 & 179 & 12.20 & 0.0298 & 0.2023 & 2.3 & 18.51 & 13.08 & 181.3 \\
\hline 05.05. - 10.12.2011 & 18.30 & 2.78 & 14.98 & 220 & 4.57 & 0.0035 & 0.0809 & 7.2 & 26.91 & 4.69 & 227.2 \\
\hline Glavna krivulja $\phi$ & 31.60 & & & & & 0.0317 & 0.0970 & & & & \\
\hline
\end{tabular}

Tablica 3.7. Osnovni parametri recesijske krivulje za izvor Klokun

PERIOD $\quad Q_{0}\left(\mathrm{~m}^{3} / \mathrm{s}\right) Q_{1}\left(\mathrm{~m}^{3} / \mathrm{s}\right) Q_{01}\left(\mathrm{~m}^{3} / \mathrm{s}\right) \mathrm{t}_{1}$ (dani) $Q_{02}\left(\mathrm{~m}^{3} / \mathrm{s}\right)$

\begin{tabular}{|c|c|c|c|c|c|c|c|c|c|c|c|}
\hline PERIOD & $Q_{0}\left(m^{3} / s\right)$ & $Q_{1}\left(m^{3} / s\right)$ & $Q_{01}\left(m^{3} / s\right)$ & $t_{1}$ (dani) & $Q_{02}\left(m^{3} / s\right)$ & $\alpha_{1}$ & $\alpha_{2}$ & a (dani) & $Q_{01}^{\prime}\left(m^{3} / s\right)$ & $Q_{02}^{\prime}\left(m^{3} / s\right)$ & $\mathrm{t}_{1}{ }^{\prime}$ (dani) \\
\hline 24.04. - 02.09.1990 & 81.69 & 3.39 & 76.58 & 132 & 21.85 & 0.0184 & 0.2509 & 0.0 & 76.58 & 21.85 & 132.0 \\
\hline 10.06. - 13.10.1991 & 54.42 & 4.63 & 38.08 & 126 & 28.58 & 0.0203 & 0.4073 & 0.8 & 52.64 & 29.05 & 126.8 \\
\hline 06.04. - 30.09.2000 & 42.71 & 2.75 & 34.95 & 178 & 9.35 & 0.0086 & 0.1095 & 6.6 & 71.80 & 9.89 & 184.6 \\
\hline 18.06. - 14.10.2004 & 20.05 & 3.92 & 13.46 & 119 & 6.69 & 0.0072 & 0.1001 & 17.0 & 74.13 & 7.56 & 136.0 \\
\hline
\end{tabular}




\section{Efektivna površina sliva}

Modeli oborina-otjecanje desetljećima (Le Moine et al. 2007) pokušavaju riješiti „propuštajuće“ slivove, pogotovo u okršenim heterogenim sustavima kao što je primjer u ovom radu. Izvor Opačac se nalazi nekakvih $60 \mathrm{~m}$ od ruba Imotskog polja, zajedno s drugim manjima izvorima koji su svi punjeni podzemnim tokovima sa sjevernog i sjeveroistočnog zaleđa, što je potvrđeno traserskim testom (Bojanić et al. 1981). Izvor ima strukturu sifonskog tipa, i prema Charlier et al. (2012), može izazvati sužavanje područja prihranjivanja u slučaju niske hidrauličke povezanosti, tj. kada je bazno otjecanje malo. Kako bi se istražio utjecaj površine sliva kao vremenski neovisne varijable, uvedene su mjesečne površine sliva (Slika 3.11.) da bi se uključile unutarnje promjene u razini podzemne vode. Prema Jukić i Denić-Jukić (2009), mjesečne varijacije mogu predstavljati karakteristike funkcioniranja krškog izvora tijekom hidrološke godine.

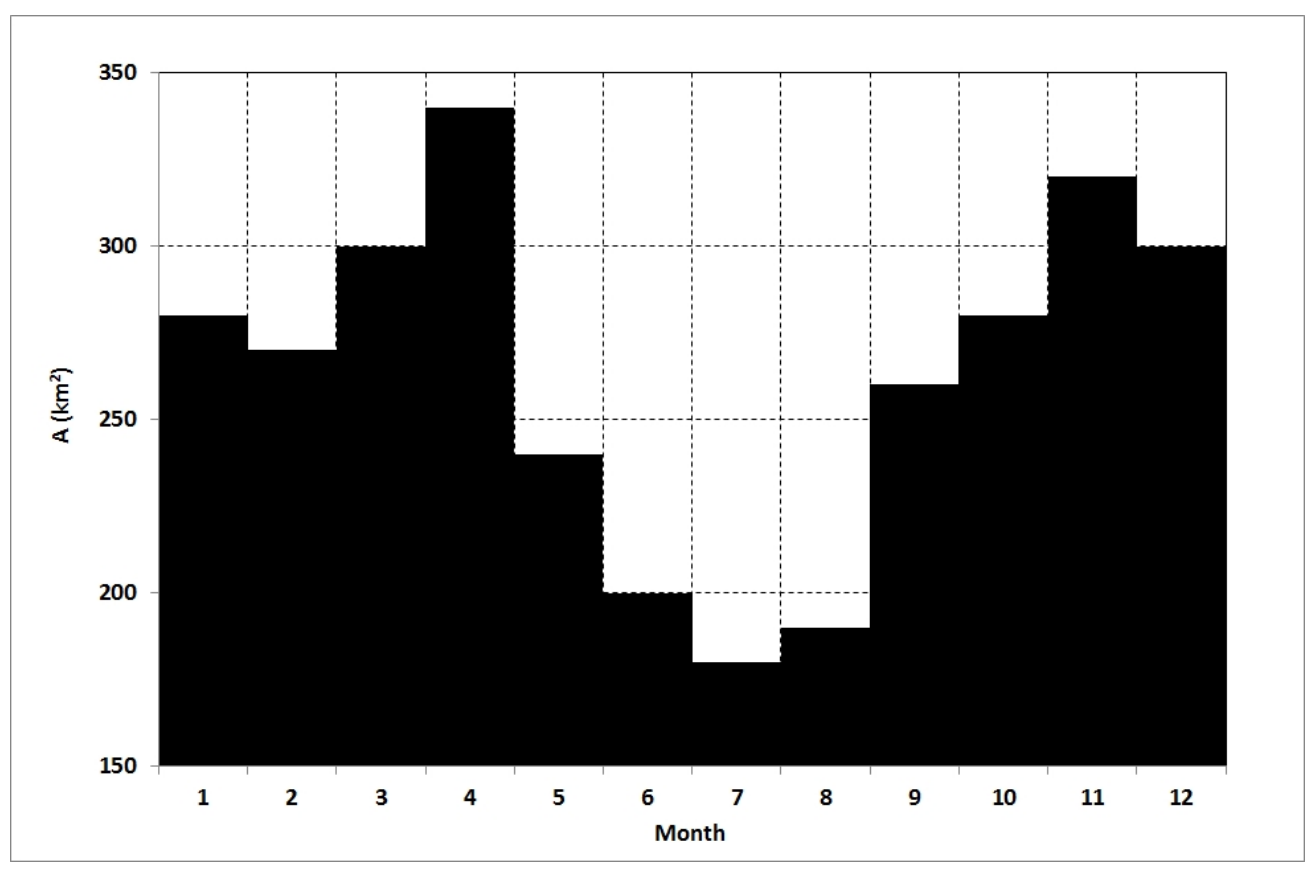

Slika 3.11. Mjesečne vrijednosti površine sliva za izvor Opačac

Prvo, za izračun prosječne godišnje površine sliva korištena je Turc-ova (1954) jednadžba godišnjeg gubitka i rezultati su uspoređeni s onima dobivenim u SMB modelu. Za dostupnih 15 hidroloških godina (period od rujna do kolovoza), slivna površina za izvor Opačac prema SMB modelu uzima vrijednosti u rasponu od 245 do $371 \mathrm{~km}^{2}$, a prema Turc-ovoj metodi proračuna godišnjeg deficita, u rasponu od 220 do $580 \mathrm{~km}^{2}$. Također su izračunati godišnji koeficijenti otjecanja, te su koeficijenti dobiveni iz modela bili kontinuirano niži, u prosjeku 15\%, od koeficijenata dobivenih Turc-ovom metodom. Da bi se dobili precizniji koeficijenti unutar hidrološke godine, za koeficijente otjecanja i površinu sliva odabrana je vremenska skala na razini mjesečne varijacije. Odmah se primijetilo da Turc-ova metoda nije primjenjiva za 
mjesečne proračune, pa su prosječne vrijednosti za koeficijente otjecanja, dobivene Palmerovom metodom, 0.75 za siječanj i 0.02 za srpanj. Te vrijednosti također nisu upotrebljive kao direktni ulazni podatak za mjesečnu efektivnu površinu, ali pokazuju da postoje razlike u koeficijentima u tijeku godine. Slika 3.11. prikazuje simulaciju mjesečnih promjena površina sliva tako da se površine sukcesivno smanjuju uslijed smanjenja samih koeficijenata (te povećavaju nakon ljetnih mjeseci). Potrebno je naglasiti da je model inicijalno kalibriran s površinom sliva kao vremenski nepromjenjivim parametrom. Jednom uspostavljena optimalna vrijednost, rastavljena je metodom pokušaja i pogrešaka na mjesečne vrijednosti, prateći empirijsko smanjenje koeficijenata otjecanja, a sve da bi se testirala njena prilagodljivost pretpostavljenoj mjesečnoj efektivnoj površini.

\subsubsection{Kalibracija modela}

Da bi se hidrološki model mogao primijeniti nužno i osnovno je izvršiti kalibraciju i verifikaciju modela. Kalibracija se sastoji od identifikacije parametara modela koji daju najmanju pogrešku između simuliranih i mjerenih vrijednosti otjecanja za izvor Opačac. Nepoznate vrijednosti i parametri za analizirane vremenske intervale se određuju minimalizacijom razlika između mjerenih i simuliranih protoka. Kvaliteta preklapanja simuliranih i mjerenih vrijednosti je definirana pomoću Nash-Sutcliffe-ovog koeficijenta efikasnosti:

$$
N S=1-\frac{\sum\left(Q_{\text {measured }}-Q_{\text {simulated }}\right)^{2}}{\sum\left(Q_{\text {measured }}-Q_{\text {mean }}\right)^{2}}
$$

gdje je $N S$ kriterij s rasponom između $-\infty$ i 1, gdje 1 znači savršeno preklapanje između simuliranog i mjerenog hidrograma a negativne vrijednosti znače da je aritmetička sredina mjerenog hidrograma bolje procijenjena nego kod simuliranog hidrograma.

Pearsonov $R^{2}$ koeficijent određenosti daje mjeru koliko dobro je model u stanju replicirati simulirane protoke, kao razmjer ukupne varijacije izlaza objašnjenih modelom:

$$
R^{2}=\frac{\sum\left(Q_{\text {measured }}-Q_{\text {mea,mean }}\right)\left(Q_{\text {simulated }}-Q_{\text {sim }, \text { mean }}\right)}{\sqrt{\sum\left(Q_{\text {measured }}-Q_{\text {mea,mean })}\right)^{2} \sum\left(Q_{\text {simulated }}-Q_{\text {sim }, \text { mean })}\right)^{2}}}
$$

RMSE - korijen srednje kvadratne pogreške je često korištena mjera za razliku između vrijednosti predviđenih modelom predstavljajući standardnu devijaciju razlika između predviđenih i izmjerenih vrijednosti:

$$
R M S E=\sqrt{\frac{\sum\left(Q_{\text {measured }}-Q_{\text {simulated }}\right)^{2}}{N}}
$$


gdje je $N$ broj izmjerenih vrijednosti. Uz RMSE dodatno se koristi i samo srednja kvadratna pogreška (MSE) i suma kvadratnih pogrešaka (SSE) kao mjera učinkovitosti kalibracije različitih modela - u ovom slučaju konceptualnog modela linearnih rezervoara i parametarskog modela neuralnih mreža.

Vremenski korak modela je jedan dan. Da bi se procijenila kvaliteta modela, korištena je standardna shema testiranja na podijeljenom uzorku (Klemeš, 1986). Za kalibraciju su korišteni periodi od 1, 2, 5 i 7 uzastopnih godina a ostatak dostupnih podataka je korišten za verifikaciju. Kako bi oba koeficijenta bila pažljivo promatrana u prvom koraku kalibracije, za koeficijent recesije brzog otjecanja $\alpha_{q}$ i težinski koeficijent distribucije efektivne oborine $-\Theta$ odabrano je 20 vrijednosti u rasponu od 0 do 1 za izvor Opačac (Tablica 3.8.). Nakon toga simulacija se ponavlja za suženi period $\alpha_{q}$ i $\Theta$ (Tablica 3.8. vrijednosti u zagradama). Kreirano je trodimenzionalno polje koje je rezultiralo s 400 rezultata simulacije u svakom koraku po svakoj VS stanici. Treba naglasiti da je odabran broj od 20 vrijednosti dovoljan s obzirom da daljnje povećanje ne doprinosi točnosti modela, a samo produljuje vrijeme proračuna. Optimalne vrijednosti $S_{\text {Smax }} i S_{\text {Emax }}$ su dobivene minimalizacijom razlika između efektivnih oborina i dotjecanja podzemnih voda, koristeći prije navedene statističke alate.

Tablica 3.8. Rezultati kalibracije i vrijednosti statističkih parametara za validacijski period izvor Opačac

\begin{tabular}{|c|c|c|c|c|c|c|c|c|}
\hline \multirow{2}{*}{ Parametar } & \multirow{2}{*}{ Jedinica } & \multicolumn{2}{|c|}{ Raspon } & \multicolumn{5}{|c|}{ Kalibracijski korak } \\
\hline & & donji & gornji & 1 & 2 & 3 & 4 & 5 \\
\hline$S_{\text {Smax }}$ & {$[\mathrm{mm}]$} & 0 & 80 & 20 & 20 & 10 & 0 & 0 \\
\hline$S_{\text {Emax }}$ & {$[\mathrm{mm}]$} & 10 & 320 & 10 & 10 & 120 & 120 & 120 \\
\hline$\alpha_{Q}$ & {$[-]$} & $0(0.1)^{*}$ & $1(0.2)$ & 0.15 & 0.12 & 0.18 & 0.17 & 0.16 \\
\hline$\theta$ & {$[-]$} & $0(0.5)$ & $1(0.7)$ & 0.55 & 0.50 & 0.57 & 0.59 & 0.58 \\
\hline$A_{E F F}$ & {$\left[\mathrm{~km}^{2}\right]$} & 219 & 498 & 262 & 262 & 287 & 305 & 308 \\
\hline & NS & & & 0.655 & 0.642 & 0.823 & 0.816 & 0.826 \\
\hline & $R^{2}$ & & & 0.819 & 0.811 & 0.915 & 0.906 & 0.911 \\
\hline & MSE & & & 0.455 & 0.448 & 1.099 & 2.869 & 4.493 \\
\hline & RMSE & & & 3.649 & 3.719 & 2.574 & 2.685 & 2.645 \\
\hline & SSE & & & 2492 & 2456 & 5620 & 11529 & 14767 \\
\hline
\end{tabular}

Uzimajući u obzir sve parametre ocjene modela, optimalna simulacija za izvor Opačac postignuta je s maksimalnim kapacitetom vlage u tlu i $0 \mathrm{~mm}$ pokrova tla te $120 \mathrm{~mm}$ uskladištenja gornje zone krša. Nedostatak vrijednosti za kapacitet pokrova tla $-S_{s}$ ukazuje na vremenski nepromjenjive karakteristike (Jukić, 2004). Optimalne vrijednosti su postignute na zadnjem koraku kalibracije s vrijednostima: odnos linearnih rezervoara $\Theta=0.58$, koeficijent 
brzog otjecanja, $\alpha_{q}=0.16$, prosječna površina sliva od $308 \mathrm{~km}^{2}$.

Tablica 3.9. Rezultati kalibracije i vrijednosti statističkih parametara za validacijski period izvor Grudsko vrelo

\begin{tabular}{|c|c|c|c|c|c|c|c|c|}
\hline \multirow{2}{*}{ Parametar } & \multirow{2}{*}{ Jedinica } & \multicolumn{2}{|c|}{ Raspon } & \multicolumn{5}{|c|}{ Kalibracijski korak } \\
\hline & & donji & gornji & 1 & 2 & 3 & 4 & 5 \\
\hline$\overline{\mathrm{S}_{\text {Smax }}}$ & {$[\mathrm{mm}]$} & 0 & 80 & 20 & 20 & 0 & 0 & 0 \\
\hline $\mathrm{S}_{\mathrm{Emax}}$ & {$[\mathrm{mm}]$} & 10 & 320 & 120 & 120 & 120 & 120 & 120 \\
\hline$\alpha_{Q}$ & {$[-]$} & 0 & 0.15 & 0.01 & 0.01 & 0.03 & 0.03 & 0.03 \\
\hline$\theta$ & {$[-]$} & 0.57 & 0.90 & 0.63 & 0.63 & 0.57 & 0.57 & 0.57 \\
\hline$A_{E F F}$ & {$\left[\mathrm{~km}^{<}\right]$} & 14 & 0 & 147 & 147 & 122 & 122 & 123 \\
\hline & NS & & & 0.656 & 0.655 & 0.858 & 0.857 & 0.844 \\
\hline & $R^{2}$ & & & 0.820 & 0.820 & 0.937 & 0.937 & 0.936 \\
\hline & MSE & & & 1.890 & 0.008 & 2.105 & 0.020 & 5.295 \\
\hline & RMSE & & & 1.650 & 0.143 & 1.223 & 0.116 & 1.380 \\
\hline & SSE & & & 2761 & 12 & 1536 & 15 & 1933 \\
\hline
\end{tabular}

Za izvor Grudsko vrelo na raspolaganju su dvije vremenske serije protoka koje je moguće analizirati: od 1995. do 2002. godine (1. period) te od 2006. do 2010. godine (2. period). Rezultati u Tablici 3.8. prezentirani su na slijedeći način: prvi kalibracijski korak odnosi se na 1. period u kojem je pola razdoblja (4 godine) korišteno za kalibraciju a druga polovica za validaciju. Isti periodi su korišteni i u drugom kalibracijskom koraku ali sa transformiranim ulaznim vrijednostima protoka:

$$
x_{i}^{\prime}=\frac{x_{\text {high }}-x_{\text {low }}}{x_{\max }-x_{\min }} \cdot x_{i}-\frac{x_{\text {low }} \cdot x_{\max }-x_{\text {high }} \cdot x_{\min }}{x_{\max }-x_{\min }}
$$

Linearnom transformacijom se varijabla $x_{i}$ može skalirati tako da njene vrijednosti iz intervala $\left[\mathrm{x}_{\min }, \mathrm{x}_{\max }\right]$ budu prebačene $\mathrm{u}$ interval $\left[\mathrm{x}_{\text {low }}, \mathrm{x}_{\text {high }}\right]$, pri čemu se skalirane vrijednosti varijable $\mathrm{x}_{\mathrm{i}}^{\prime}$ može izračunati prema izrazu (3.28). Želja je ispitati osjetljivost modela na vrijednosti 0 koji se pojavljuju (izvor presušuje) a korištena numerička integracija ne može "predvidjeti" ovakve podatke. Treći kalibracijski korak koristi 2. period s tim da su 3 godine odabrane za kalibraciju a dvije za validaciju. U četvrtom koraku se nad 2. periodom provodi transformacija podataka te se $\mathrm{u}$ petom koriste 4 godine netransformiranih podataka za 2. period. Rezultati pokazuju da transformacija podataka nije značajnije pridonijela točnosti modela. Optimalne vrijednosti su postignute u trećem koraku kalibracije s vrijednostima: odnos linearnih rezervoara $\Theta=0.57$, koeficijent brzog otjecanja, $\alpha_{q}=0.03$, prosječna površina sliva od $123 \mathrm{~km}^{2}$. Zanimljivo je uočiti da su optimalni maksimalni kapaciteti tla $S_{\operatorname{Smax}}=0 \mathrm{~mm}$ i $S_{E \max }=120 \mathrm{~mm}$ isti kao i za izvor Opačac što bi mogla biti naznaka nepromijenjenih uvjeta u SZ i JI dijelu Imotskog polja. Prethodna procjena koeficijenta brzog otjecanja (0.04) se pokazala dobra u odnosu na rezultate 
modela $(0.03)$, no procjena $\mathrm{BFI}=0.77$ odstupa od ekvivalentne vrijednosti odnosa sporog $\mathrm{i}$ brzog linearnog rezervoara $(0.57)$.

Stanica VS Peć Mlini, niz i MS Imotski imaju zajednički period osmatranja u trajanju od 13 godina: 1.1.1990. - 31.12. 2002. Treba napomenuti da Peć Mlini, niz. dobro korelira i sa MS Vrgorac (Tablica 2.9. 2. poglavlje) ali su dostupni samo kraći periodi za razmatranje stoga su izvršene analize na obje MS stanice sa prikazom perioda kalibracije i validacije u Tablici 3.10. Rezultati kalibracijskog postupka prikazani su u Tablici 3.11. Optimalni rezultati ostvareni su za 4. kalibracijski korak za vrijednosti $S_{\text {Smax }}=10 \mathrm{~mm}$ i $S_{\text {Emax }}=120 \mathrm{~mm}$. Svi koraci pokazuju postojanje gornjeg sloja $\left(S_{\text {Smax }} 10\right.$ ili $\left.20 \mathrm{~mm}\right)$ što nije slučaj kod prethodna dva analizirana izvora. Procijenjena vrijednosti $\alpha_{q}(0.10)$ je manja od optimalne vrijednosti 0.17 dok srednji BFI $=0.65$ podcjenjuje vrijednosti $\Theta$ (optimalni) $=0.83$. Prosječna površina je $484 \mathrm{~km}^{2}$.

Tablica 3.10. Kalibracijski i validacijski periodi za VS Peć Mlini, nizvodno

\begin{tabular}{ccc} 
Kalibracijski korak & Period kalibracije & Period validacije \\
\hline 1 & 1990 Imotski & $1991-2002$ Imotski \\
2 & $1990-1991$ Imotski & $1992-2002$ Imotski \\
3 & $1990-1993$ Imotski & $1994-2002$ Imotski \\
4 & $1990-1996$ Imotski & $1997-2002$ Imotski \\
5 & $1990-1999$ Imotski & $2000-2002$ Imotski \\
6 & $1991-1994$ Vrgorac & $2010-2011$ Vrgorac \\
7 & $1999-2002$ Vrgorac & $2010-2011$ Vrgorac
\end{tabular}

Tablica 3.11. Rezultati kalibracije i vrijednosti statističkih parametara za validacijski period izvor Tihaljina

\begin{tabular}{|c|c|c|c|c|c|c|c|c|c|c|}
\hline \multirow{2}{*}{ Parametar } & \multirow{2}{*}{ Jedinica } & \multicolumn{2}{|c|}{ Raspon } & \multicolumn{7}{|c|}{ Kalibracijski korak } \\
\hline & & donji & gornji & 1 & 2 & 3 & 4 & 5 & 6 & 7 \\
\hline $\mathrm{S}_{\text {Smax }}$ & {$[\mathrm{mm}]$} & 0 & 80 & 20 & 20 & 20 & 10 & 10 & 20 & 20 \\
\hline $\mathrm{S}_{\text {Emax }}$ & {$[\mathrm{mm}]$} & 10 & 320 & 120 & 120 & 120 & 120 & 120 & 10 & 10 \\
\hline$\alpha_{Q}$ & {$[-]$} & 0.01 & 0.2 & 0.19 & 0.16 & 0.18 & 0.17 & 0.17 & 0.05 & 0.05 \\
\hline$\theta$ & {$[-]$} & 0.5 & 0.83 & 0.50 & 0.68 & 0.73 & 0.83 & 0.83 & 0.50 & 0.50 \\
\hline$A_{E F F}$ & {$\left[\mathrm{~km}^{2}\right]$} & 0 & 0 & 411 & 428 & 456 & 484 & 503 & 298 & 254 \\
\hline & NS & & & 0.611 & 0.761 & 0.766 & 0.794 & 0.758 & 0.760 & 0.760 \\
\hline & $\mathrm{R}^{2}$ & & & 0.865 & 0.894 & 0.895 & 0.900 & 0.890 & 0.878 & 0.878 \\
\hline & MSE & & & 0.912 & 2.049 & 5.793 & 29.865 & 76.944 & 53.864 & 68.483 \\
\hline & RMSE & & & 7.165 & 5.551 & 5.705 & 4.692 & 5.209 & 8.887 & 8.887 \\
\hline & SSE & & & 3996 & 8231 & 19042 & 65435 & 84330 & 39321 & 49992 \\
\hline
\end{tabular}


Na kraju je obrađena i stanica VS Klobuk u neposrednoj blizini izvora Klokun, za koju je prethodnom analizom podataka utvrđeno da dobro korelira sa padalinama zabilježenima na stanicama Vrgorac i Imotski. Slijedeći preporuke o nepristranom pristupu u ocjeni modela (Klemeš,1986) određeni su kalibracijski i validacijski periodi prema Tablici 3.12. Na ovaj način su se iskoristile sve dostupne godine za koje postoji zajednički period podataka tako da je najduži period iskorišten za kalibraciju i neovisni set (jedna ili dvije godine) za validaciju.

Tablica 3.12. Kalibracijski i validacijski periodi za VS Klokun

\begin{tabular}{ccc} 
Kalibracijski korak & Period kalibracije & Period validacije \\
\hline 1 & $1999-2002$ Vrgorac & 1991 Vrgorac \\
2 & $1999-2002$ Vrgorac & 1996 Vrgorac \\
3 & $1995-2002$ Imotski & $1990-1991$ Imotski \\
4 & $1995-2002$ Imotski & 2004 Imotski
\end{tabular}

Rezultati testiranja modela prikazani su u Tablici 3.13. Optimalni rezultati ostvareni su za 3. kalibracijski korak za vrijednosti $S_{S \max }=20 \mathrm{~mm}$ i $S_{E m a x}=120 \mathrm{~mm}$, no ove vrijednosti se uzimaju sa rezervom jer su i rezultati 4 . koraka statistički dobri a ukazuju na vrijednosti $S_{\text {Smax }}=$ $80 \mathrm{~mm}$ i $S_{E \max }=40 \mathrm{~mm}$. Kalibrirane vrijednosti $\alpha_{q}=0.15$ i $\Theta=0.63$ su unutar prethodno ocijenjenih intervala pomoću analize recesijske krivulje $\alpha_{q}=[0.1,0.4]$ i separacije hidrograma otjecanja BFI $=[0.60,0.73]$. Efektivna površina sliva u ovom slučaju je značajna $-1046 \mathrm{~km}^{2}$ što može biti indikacija podzemnog dotjecanja. U Tablici 3.14. su sumirane značajke izvora dobivene modelom (koef. sporog otjecanja $\alpha_{B}$ dobiven je analizom recesijske krivulje).

Tablica 3.13. Rezultati kalibracije i vrijednosti statističkih parametara za validacijski period izvor Klokun

\begin{tabular}{|c|c|c|c|c|c|c|c|}
\hline \multirow{2}{*}{ Parametar } & \multirow{2}{*}{ Jedinica } & \multicolumn{2}{|c|}{ Raspon } & \multicolumn{4}{|c|}{ Kalibracijski korak } \\
\hline & & donji & gornji & 1 & 2 & 3 & 4 \\
\hline $\mathrm{S}_{\mathrm{Smax}}$ & {$[\mathrm{mm}]$} & 0 & 80 & 20 & 80 & 20 & 80 \\
\hline $\mathrm{S}_{\text {Emax }}$ & {$[\mathrm{mm}]$} & 10 & 320 & 120 & 40 & 120 & 40 \\
\hline$\alpha_{Q}$ & {$[-]$} & 0.1 & 0.4 & 0.14 & 0.14 & 0.15 & 0.19 \\
\hline$\theta$ & {$[-]$} & 0.6 & 0.73 & 0.60 & 0.60 & 0.63 & 0.73 \\
\hline$A_{E F F}$ & {$\left[\mathrm{~km}^{2}\right]$} & 0 & 0 & 530 & 644 & 1046 & 1229 \\
\hline & NS & & & 0.701 & 0.773 & 0.828 & 0.784 \\
\hline & $R^{2}$ & & & 0.842 & 0.920 & 0.917 & 0.897 \\
\hline & MSE & & & 300.8 & 305.0 & 307.8 & 699.1 \\
\hline & RMSE & & & 14.028 & 15.205 & 9.567 & 9.671 \\
\hline & SSE & & & 109783 & 111341 & 224691 & 255888 \\
\hline
\end{tabular}


Tablica 3.14. Karakteristike izvora prema konceptualnom modelu

\begin{tabular}{cccccc} 
& & \multicolumn{4}{c}{ izvor } \\
& Opačac & Grudsko vrelo & Tihaljina & Klokun \\
\hline $\mathbf{S}_{\mathrm{Smax}}$ & {$[\mathrm{mm}]$} & 0 & 0 & 10 & 20 \\
$\boldsymbol{S}_{\mathrm{Emax}}$ & {$[\mathrm{mm}]$} & 120 & 120 & 120 & 120 \\
$\boldsymbol{\alpha}_{\mathrm{Q}}$ & {$[-]$} & 0.16 & 0.03 & 0.11 & 0.15 \\
$\boldsymbol{\alpha}_{\mathrm{B}}$ & {$[-]$} & 0.007 & 0.041 & 0.032 & 0.013 \\
$\boldsymbol{\theta}$ & {$[-]$} & 0.58 & 0.57 & 0.79 & 0.63 \\
$\mathbf{A}_{\mathrm{EFF}}$ & {$\left[\mathrm{km}^{2}\right]$} & 308 & 122 & 484 & 1046
\end{tabular}

\subsubsection{Rezultati}

$\mathrm{Na}$ slici 3.12. i 3.13. prikazane su simulacije za izvor Opačac obavljene nakon kalibracije i verifikacije modela, respektivno. Prikaz krivulja opadanja je adekvatan i mali protoci su bliski mjerenim vrijednostima. Vršne vrijednosti su većinom podcijenjene što se može objasniti prisutnošću među-slivnog podzemnog toka. Bonacci (2008) je u studiji o vodnim gubicima iz akumulacije Ričice, koja se nalazi u blizini izvora Opačac utvrdio da većina toka podzemne vode iz gornjeg dijela rijeke Ričina izlazi na izvoru rijeke Vrljika, što je i potvrđeno traserskim testom 1997-e godine. Tijekom intenzivnih oborina, dodatni tokovi se aktiviraju i doprinose ukupnom protoku na izvoru Opačac. Većina pogrešaka u simuliranim protocima je detektirana za vrijeme oborinski intenzivnih perioda. Za vrijeme velikih protoka, kratki recesijski periodi imaju strmije opadanje ka minimalnim protocima i padovi u protoku se dešavaju naglo u odnosu na ono što model predviđa.

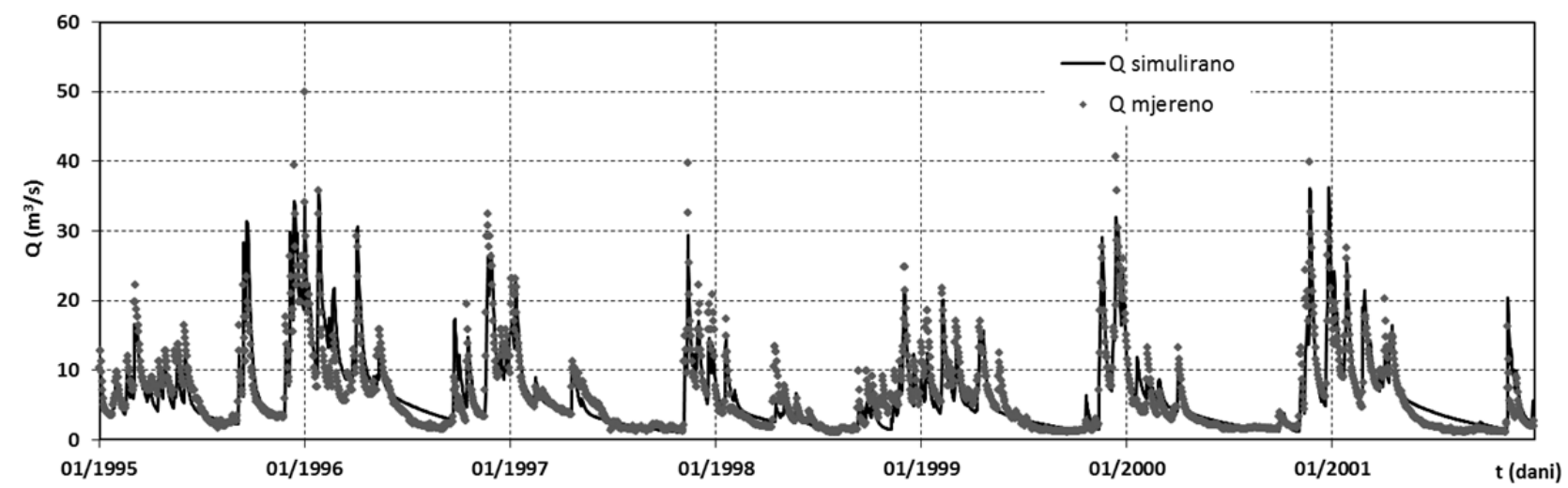

Slika 3.12. Simulirani i izmjereni protok za kalibracijski period - izvor Opačac 


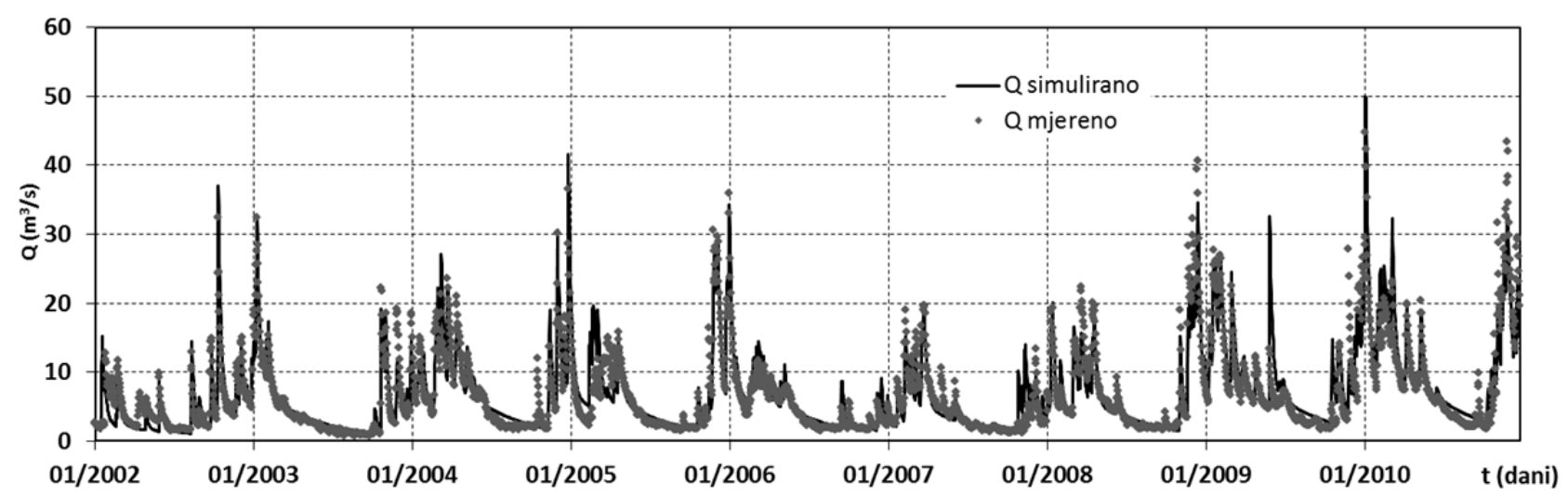

Slika 3.13. Simulirani i izmjereni protok za validacijski period - izvor Opačac

Može se primijetiti da korištenje samo jednog koeficijenta za rezervoar brzog otjecanja nije zadovoljavajuće. Prethodni matematički izraz dobiven preklapanjem eksponencijalne jednadžbe (3.19) je pomogao u boljem razumijevanju dva karakteristična dijela recesijske krivulje. Također, procjena krivulje korištenjem papira s polu-logaritamskim mjerilom omogućava korisniku vizualnu kontrolu u izboru najreprezentativnije recesijske krivulje, te neprikladni podaci mogu bit isključeni iz analize (Nathan i McMahon, 1990). Ovaj koncept opravdava korištenje dva recesijska koeficijenta i pomaže u boljem razumijevanju promatranog krškog sustava. Promatranjem recesijske krivulje, može se vidjeti da je odgovor sustava vrlo brz - vršna otjecanja se javljaju dan-dva nakon oborina. Opadanje se događa gotovo linearno u sljedećih 10 do 20 dana. Razlika između $\alpha_{b}<<\alpha_{q}$ uspješno prikazuje drugi dio krivulje recesije $s$ vrlo dugačkim padom.

Funkcija kros-korelacije (Padilla i Pulido-Bosch, 1995) također prikazuje ove elemente (Slika 2.19) - opći oblik funkcije je sličan krivulji opadanja s brzim padom vrijednosti za prvih 17 dana s vršnom vrijednošću na vremenskom odmaku od jednog dana. Funkcija niskih vrijednosti se potom sporo i nepravilno približava nuli sve dok nije postignut vremenski odmak od okvirno 120 dana. Niske vrijednosti koje slijede nakon inicijalno brzog pada funkcija ukazuju na dominaciju odgovora brzog otjecanja, a dugo vrijeme odmaka sustava ukazuje na kašnjenje u infiltraciji oborine i sporijem transportu kroz sustav, što bi moglo predstavljati prisutnost pokrova od krškog sedimenta (Kuhta et al. 2012). Dvojnost sustav je jasno vidljiva, ne samo u smislu fizičkih svojstava već i u vremenskim karakteristikama. Daljnje istraživanje bi se trebalo fokusirati na otkrivanju razloga za ovakvo ponašanje sustava. 


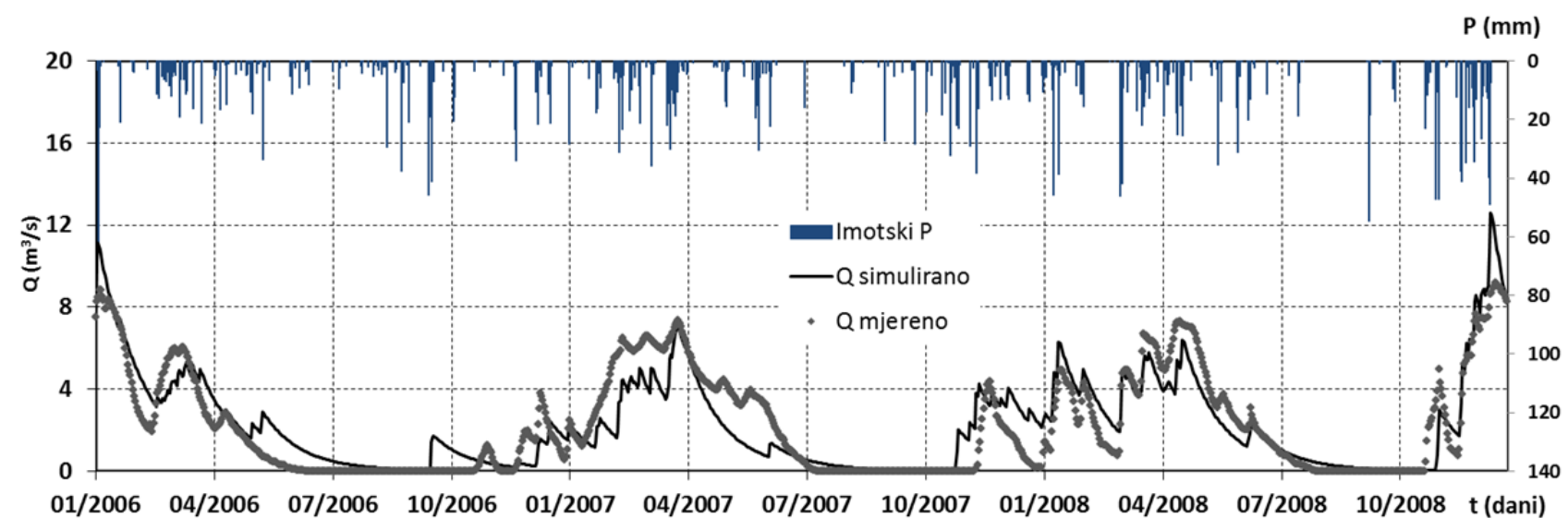

Slika 3.14. Simulirani i izmjereni protok za kalibracijski period - izvor Grudsko vrelo i zabilježene padaline na MS Imotski

Rezultati kalibracijskog perioda za izvor Grudsko vrelo su na Slici 3.14. a validacijskog perioda na Slici 3.15. Grudsko vrelo ima karakteristike uglavnom sporog otjecanja. Simulacija koja se temelji na dva rezervoara definitivno utječe na konačni rezultat jer sa koeficijentom brzog otjecanja oblikuje krivulja strmijeg pada npr. od 4 mjeseca 2007. godine do 7. mjeseca 2007. (Slika 3.14.). Uspoređujući oborine (Slika 3.14. i 3.15. Imotski P) sa izlaznim mjerenim protocima zaključeno je da izvor ne reagira podjednako na ulaznu vremensku seriju: 2.6.2009. zabilježena je maksimalna dnevna količina kiše za cijeli promatrani period u visini od $163 \mathrm{~mm}$ kiše i protok od $6.4 \mathrm{~m}^{3} / \mathrm{s}$ a kasnije (kraj 2009. i početak 2010.) nakon nekoliko dana prosječnih dnevnih oborina, kumulativno manjih od navedenih $163 \mathrm{~mm}$, protok iznosi $9.3 \mathrm{~m}^{3} / \mathrm{s}$. Razlog ovakvom ponašanju može se tražiti u kašnjenju odgovora sustava ali vremenski lag od 3 dana utvrđen spektralnom analizom nije moguće uočiti. Alternativna pretpostavka je postojanje većeg podzemnog provodnika koji prihranjuje izvor sa vodom iz sjevernog područja sliva - Rastovača i Tribistovo. Testovi bojanjem (1967. i 1985. godine) su potvrdili postojanje ovih veza. Buduća ispitivanja modela trebaju biti usmjerena $u$ definiranje navedenih količina posebnim rezervoarom.

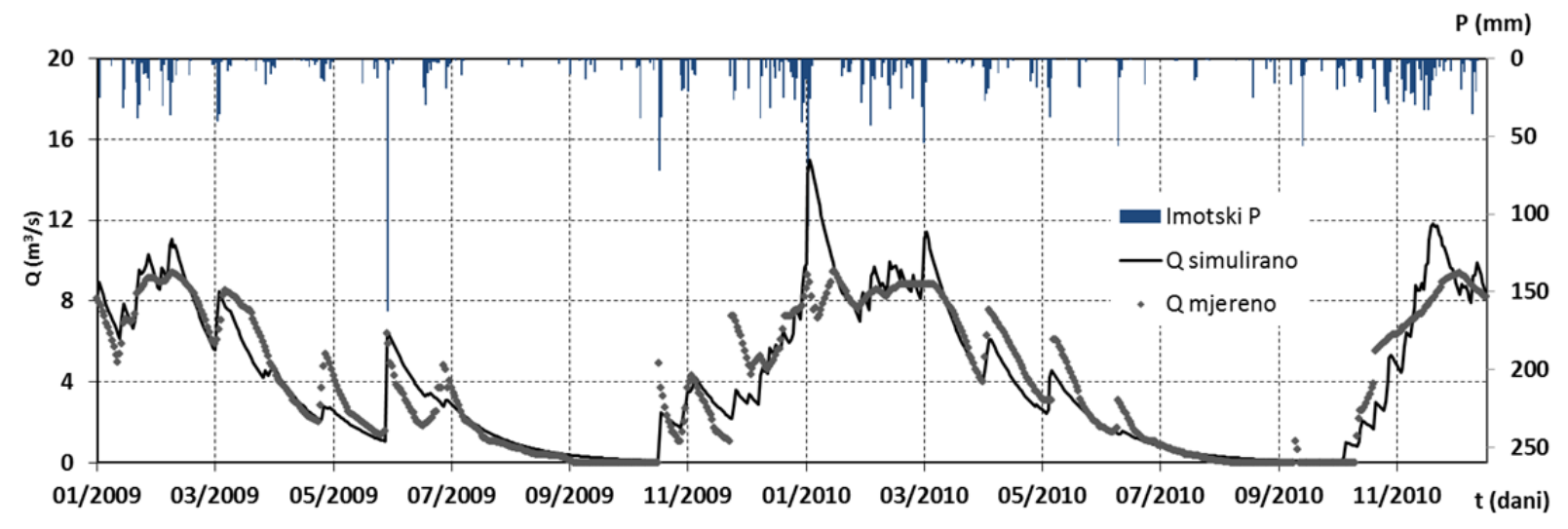

Slika 3.15. Simulirani i izmjereni protok za validacijski period - izvor Grudsko vrelo 
Kalibracijski i validacijski period VS Peć Mlini, niz. prikazani su na slikama 3.16. i 3.17. Kao i kod izvora Opačac, vršni simulirani protoci su u prosjeku 10\% niži nego izmjereni. Sličnost izvora Opačac i Tihaljina uočava se i kod raspona $\alpha_{b}$ i $\alpha_{q}$ iako se kod Tihaljine radi o većim protocima.

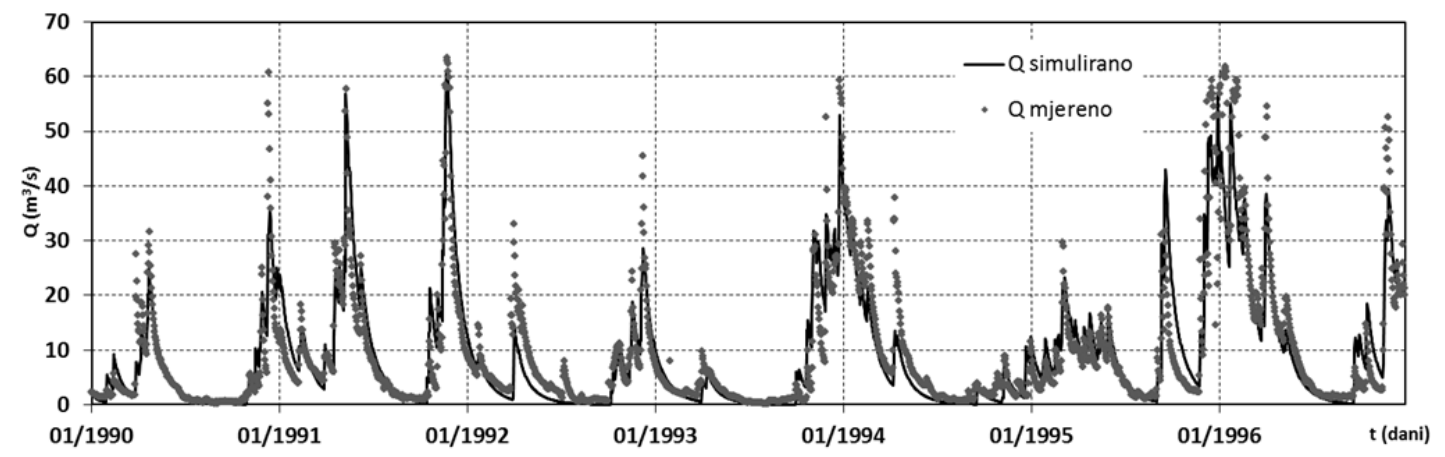

Slika 3.16. Simulirani i izmjereni protok za kalibracijski period - izvor Tihaljina

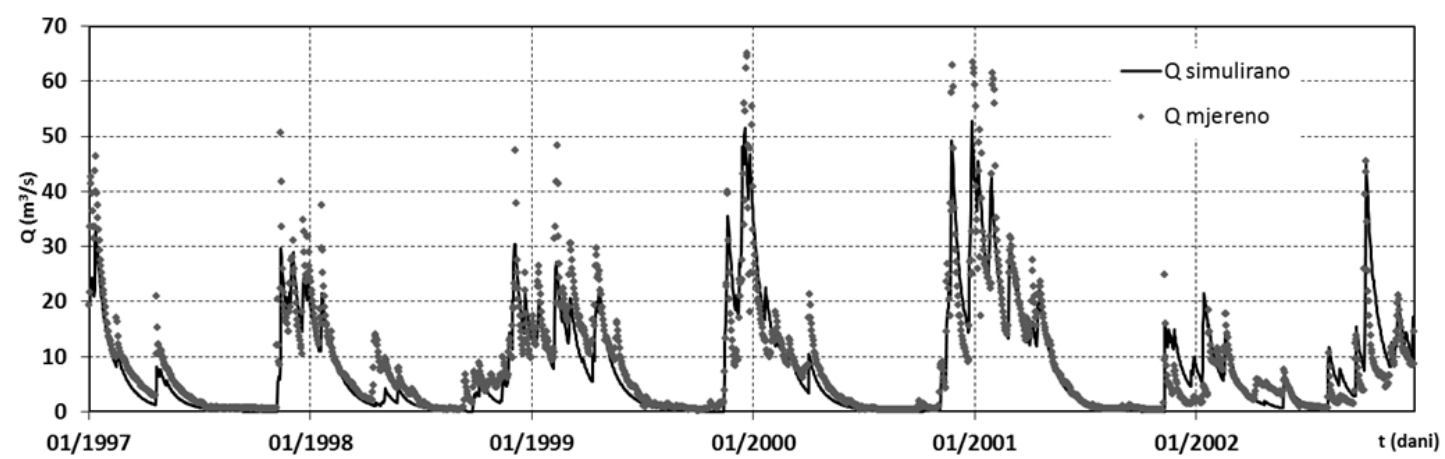

Slika 3.17. Simulirani i izmjereni protok za kalibracijski period - izvor Tihaljina

Najveći maksimalni i srednji protoci zabilježeni su na izvoru Klokun (Slika 3.18. kalibracija protoka i 3.19. validacija). Više vrijednosti brzog i sporog koeficijenta otjecanja predviđaju postojanje akvifera sa zdrobljenom vodonosnom zonom npr. zona zasjeka koja se provlači uz cijelo desno korito rijeke od izvora Tihaljina sve do ušća kraj Čapljine. Stupanj okršenosti (Malik i Vojtkova, 2012 ) bi za ovaj izvor bio veći (4.3 - 5.5.) nego kod ostalih izvora uz pretpostavku postojanja guste mreže otvorenih pukotina u kombinaciji sa freatičnim sistemom provodnika veće dužine. 


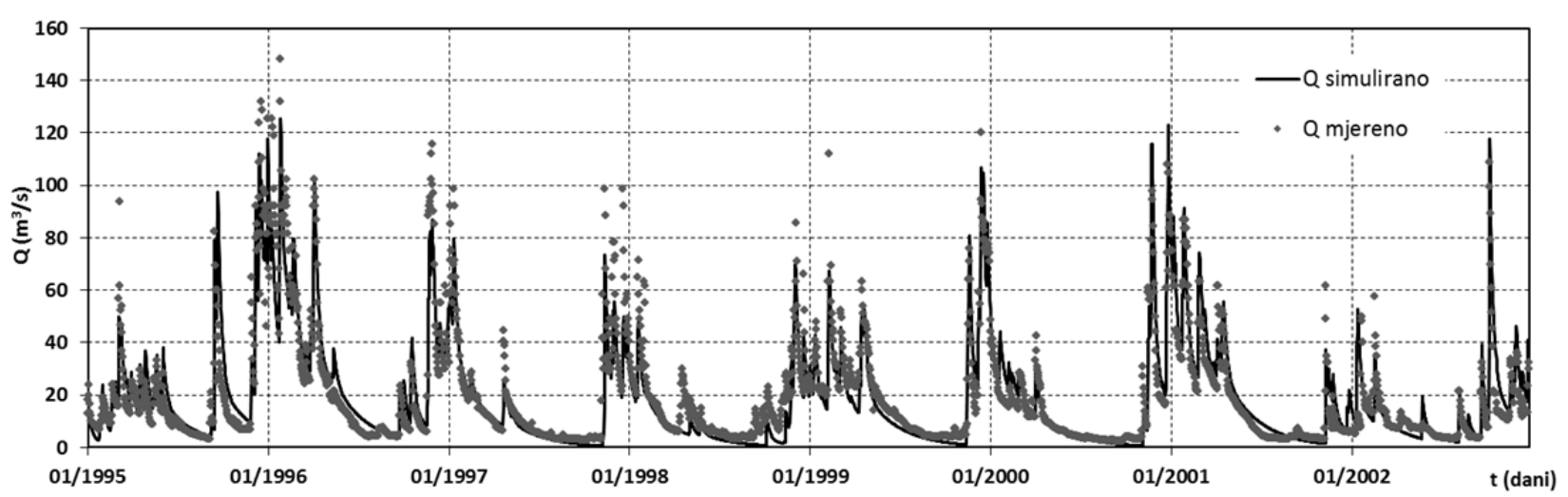

Slika 3.18. Simulirani i izmjereni protok za kalibracijski period - izvor Klokun

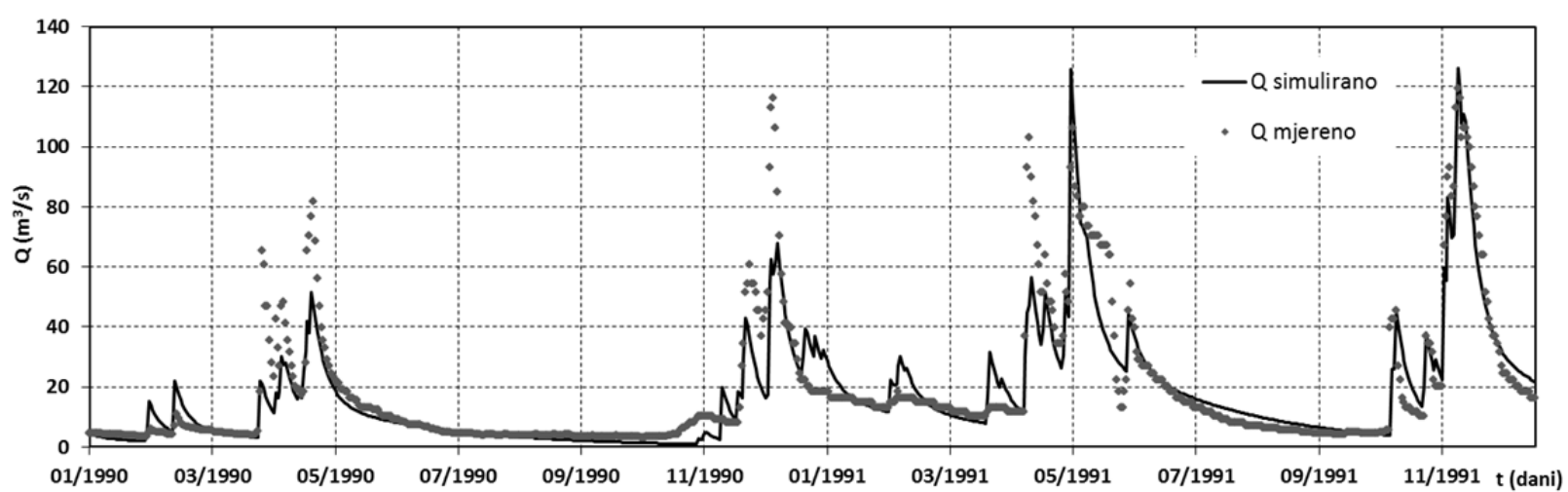

Slika 3.19. Simulirani i izmjereni protok za validacijski period - izvor Klokun

Na Slici 3.20. su prikazani rezultati primjene - a) efektivna oborina, b) ukupni dotok (recharge), brza i bazna komponenta uskladištenja (storage) podzemnog toka za izvor Opačac. Izraz efektivna oborina $\left(P_{E F F}\right)$, u ovom kontekstu, označava udio od ukupne oborine koji trenutno prihranjuje freatsku zonu vodonosnika. Ova metoda implicira da se inicijalna oborina, ostala nakon evapotranspiracije, ulazi kao vlaga u tlo sve dok se tlo ne saturira. Ostatak vode teče $u$ zatvorene depresije gdje brzo ulazi u vodonosnik putem ponora (Jukić, 2004) što dovodi do zaključka da se kapacitet podzemnog skladištenja ne može adekvatno opisati SMB modelom u periodima bez oborine. Ovakva situacija se događa u ljetnim mjesecima (lipanj-kolovoz) gdje su vrijednosti $P_{E F F}$ iznosile 0 za razliku od dotoka dobivenog iz GWB pod-modela (Slika 3.20 a) i b). 
(a)

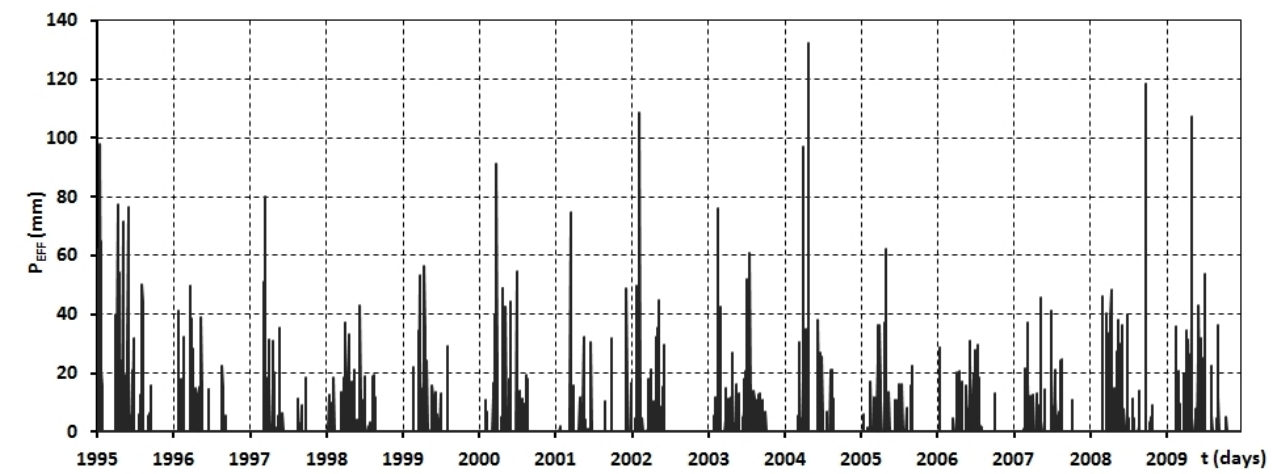

(b)

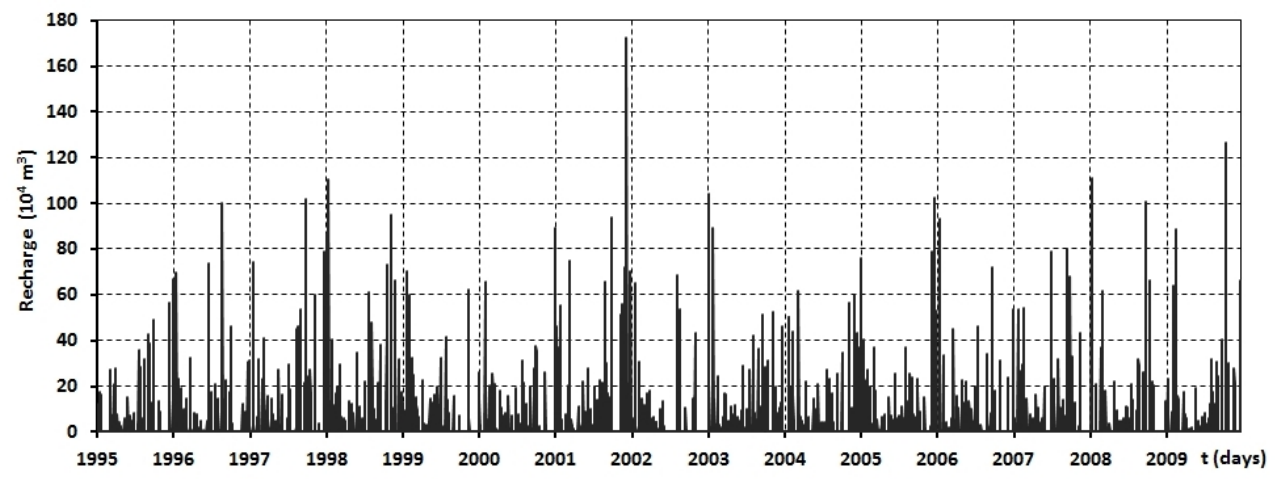

(c)

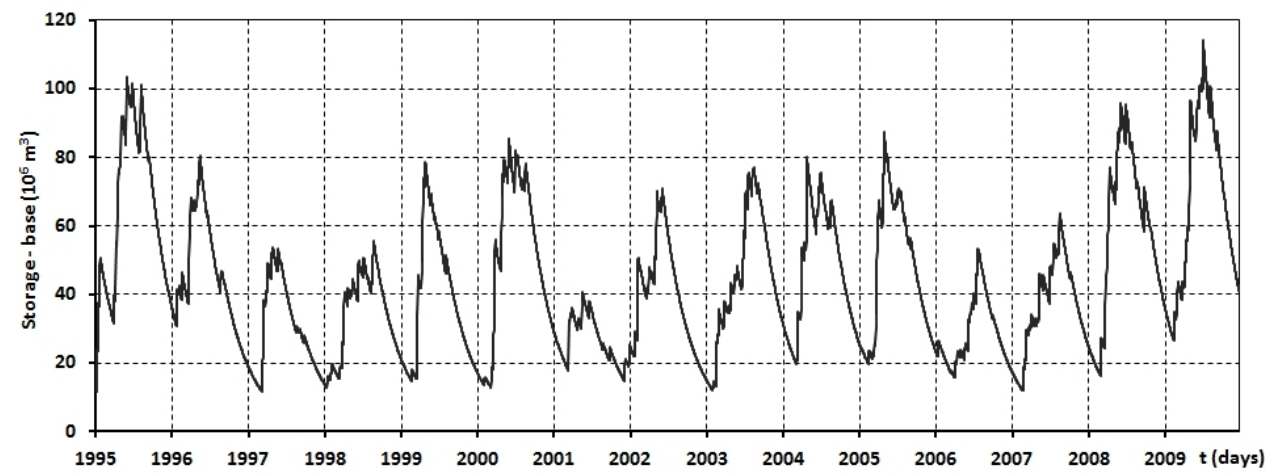

(d)

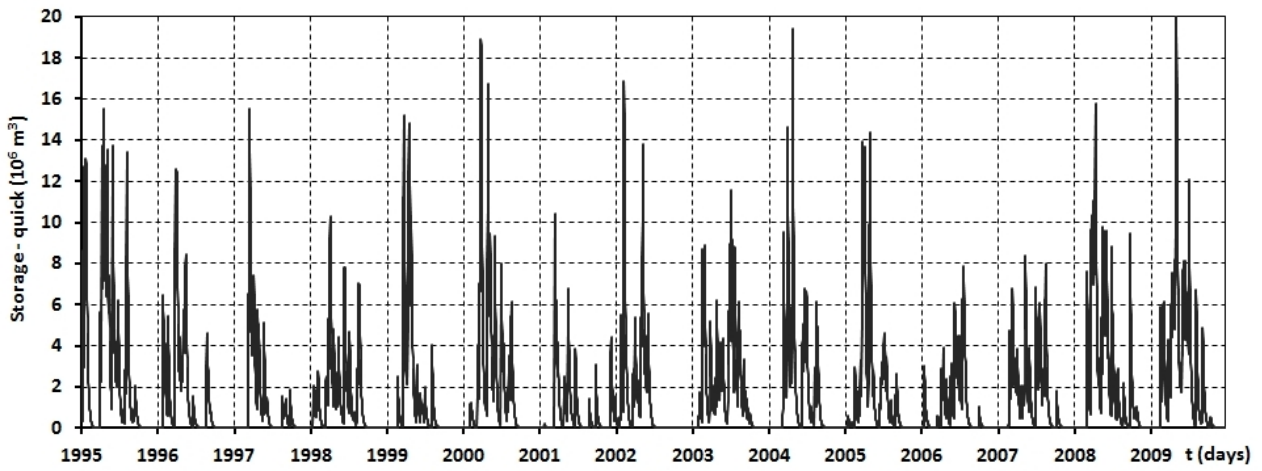

Slika 3.20. Rezultati primjene modela: a) efektivna oborina; b) ukupni dotok, c) bazna (spora) i d) brza komponenta uskladištenja

To je jedna od glavnih mana SMB modela. Također u nedostatke SMB modela, spada i izostavljanje akumulacije snijega iz proračuna - snijeg se ne topi uvijek u istom mjesecu kad i padne, te u tom slučaju modelirani $P_{E F F}$ će u periodu kad je pao imati veće vrijednosti dok će u periodu otapanja imati podcijenjene vrijednosti. Podcjenjivanje otjecanja se može dogoditi i jer 
SMB model ne promatra trajanje oborina i pretpostavlja da sva voda trenutno ide direktno u podzemlje što nije slučaj u ljetnim mjesecima. U svakom slučaju, točnost SMB modela raste $\mathrm{s}$ dužim periodima promatranja (Penzar, 1976; Pandžić et al. 2006). Ukupno skladištenje varira od 12 do 149 milijuna $\mathrm{m}^{3}$ tijekom promatranog razdoblja (Slika $3.20 \mathrm{c}$ ) i d)) pokazujući da izvor Opačac akumulira oko 137 milijuna $\mathrm{m}^{3}$ vode $\mathrm{u}$ toku godine s velikim varijacijama u podzemnoj vodi između brzog i sporog toka. Navedene simulirane vrijednosti su poprilično značajne veličine za krški vodonosnik. Ostale vrijednosti prosječnih, minimalnih i maksimalnih godišnjih volumena uskladištenja prikazane su u Tablici 3.15.

Tablica 3.15. Prosječne, minimalne i maksimalne količine godišnjeg volumena uskladištene vode za analizirane izvore

\begin{tabular}{cccc|ccc} 
& \multicolumn{3}{c}{$\begin{array}{c}\text { Volumen uskladištene vode (u milijunima } \mathbf{m}^{3} \text { ) } \\
\text { spora komponenta }\end{array}$} & Mrza komponenta \\
& AVR & MIN & MAX & AVR & MIN & MAX \\
\cline { 2 - 7 } Opačac & 46.8 & 12.0 & 126.1 & 1.6 & 0.0 & 23.0 \\
Grudsko vrelo & 3.5 & 0.0 & 20.1 & 4.3 & 0.0 & 24.5 \\
Tihaljina & 20.6 & 0.0 & 115.0 & 0.8 & 0.0 & 12.2 \\
Klokun & 72.8 & 3.9 & 289.8 & 4.1 & 0.0 & 53.5
\end{tabular}

Prosječna površina sliva, izračunata korelacijom oborine i dotjecanja podzemne vode varira tijekom kalibracijskih koraka. Da bi se riješio ovaj problem, nova varijabla je uvedena u model u obliku efektivne površine prihranjivanja zato jer se pretpostavlja da dijelovi nepravilnog podzemnog toka mogu biti prekinuti tijekom sušnih perioda čime je odsječen dio površine koja doprinosi ukupnom protoku. Prethodna istraživanja (Bojanić, 1981; Bonacci, 2008) mogu potvrditi navedene izjave. Budući da SMB model ne može simulirati ovakve uvjete, GWB model ih uključuje kao empirijske procjene u jednadžbu (3.16) gdje $A(t)$ više nije konstanta nego varijabla s vremenskim korakom od jednog mjeseca. Nekoliko različitih nizova mjesečnih efektivnih površina sliva je korišteno u simulaciji. Na Slici 3.11. prikazane su vrijednosti koje daju najbolje rezultate uzevši u obzir objektivne funkcije ocjene (NS, $R^{2}$ i $R M S E$ ). Postoji blago poboljšanje u rezultatima: $N S=0.85, R^{2}=0.92$ i $R M S E=2.35 \mathrm{~m}^{3} / \mathrm{s}$. Metoda pokušaja i pogrešaka postavlja pitanje valjanosti uzimanja površine sliva kao kalibracijskog parametra jer su procjene površine sliva za nekonzervativan sliv i vremenski promjenjive faktore ugrađene $u$ vrijednost same površine sliva izračunatog vodnom bilancom i nije ih jednostavno izvesti empirijski. Le Moine et al. (2007) su dali pregled rješenja koja mogu numerički uzeti u obzir nekonzervativno ponašanje u modelu oborina-otjecanje. Eksplicitno računanje međuslivnog protoka podzemne vode (eng. intercatchment groundwater flow - IGF) poboljšava efikasnost modela, ali ne može uspostaviti jasne veze između vrste stijena i IGF-a. Hartman et al. (2013a) su uveli kalibracijski postupak koji omogućava identifikaciju varijable površine prihranjivanja s Pareto funkcijom 
koja zahtjeva jedan parametar distribucije, ali koristi hidrokemijske podatke da bi našla odgovarajuće parametre modela, a oni svakako nisu dostupni za promatrano područje. Smjer daljnjeg istraživanja za ovo područje bi trebalo biti uvođenje drugog parametra kao praga za različite doprinose površini prihranjivanja (Charlier et al. 2012). Svakako treba naglasiti da su ranija istraživanja, provedena za izgradnju akumulacije Ričice u blizini izvora Opačac, značajno podcijenila raspravljanu vrijednost slivne površine $\left(A=25 \mathrm{~km}^{2}\right)$. Očito je da poniranje u gornjim dijelovima toka ima značajniji utjecaj na ukupni protok. Prema Bonacci i Andrić (2015) linearne regresijske analize dobivene usporedbom kumulativnih godišnjih oborina i prosječnih godišnjih protoka u obliku:

$$
Q=a \times P \pm b
$$

mogu se iskoristiti za procjenu površine sliva krškog izvora. Srednji godišnji protok izvora, Q, izražen u m³/s, moguće je definirati slijedećim izrazom:

$$
\mathrm{Q} \times \mathrm{t}=\mathrm{P} \times \mathrm{A} \times \mathrm{c}
$$

pri čemu, $t$, označava broj sekundi u godini, $P$, oborinu palu na sliv izraženu u metrima, $A$, površinu sliva izraženu $\mathrm{u} \mathrm{m}^{2}$, dok $c$ predstavlja bezdimenzionalni koeficijent otjecanja. Broj sekunda u godini koja traje 365 dana iznosi 31.536.000 sekundi, dok u prestupnoj godini koja traje 366 dana iznosi 31.622.400 sekundi. Uvrštavanjem izraza (3.29) u (3.28) moguće je

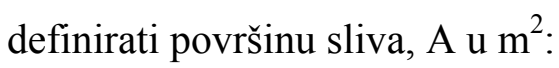

$$
\mathrm{A}=\{\mathrm{t} \times[1000 \times \mathrm{a} \pm(\mathrm{b} / \mathrm{P})]\} / \mathrm{c}
$$

U izrazima (3.29) i (3.30) jedine nepoznanica je godišnji koeficijent otjecanja, $c$. Koeficijent otjecanja, $c$, predstavlja jedan od bitnih hidroloških parametara. U njemu su integrirani svi procesi koji se u zbivaju u slivu tijekom transformiranja oborina u otjecanje (Bonacci, 2001). U Dinarskom kršu Hrvatske on je znatno viši nego u nekrškim terenima te uglavnom prelazi vrijednost od 0.5. Žugaj (1995) je za neke izvore u kršu Hrvatske izračunao da vrijednost godišnjeg koeficijenta otjecanja može preći veličinu od c $=0.7$. Izvršena linearna regresija nad parovima godišnjih padalina i otjecanja u drugom poglavlju disertacije iskorištena je kao ulaz u izraz (3.30) uz korištenje tri koeficijenta otjecanja - 0.5, 0.6 i 0.7. U Tablici 3.16. su prikazani dobiveni rezultati usporedno sa površinama dobivenim konceptualnim modelom. 
Tablica 3.16. Površine slivova promatranih krških izvora prema linearnoj regresiji i konceptualnom modelu

\begin{tabular}{lcccc} 
& \multicolumn{4}{c}{ Površina sliva $\left(\mathbf{k m}^{\mathbf{2}}\right)$} \\
& Opačac & Grudsko vrelo & Tihaljina & Klokun \\
\hline $\mathbf{c}=\mathbf{0 . 5}$ & 378 & 189 & 681 & 1110 \\
$\mathbf{c}=\mathbf{0 . 6}$ & 315 & 158 & 567 & 925 \\
$\mathbf{c}=\mathbf{0 . 7}$ & 270 & 135 & 486 & 793 \\
Model & 308 & 122 & 484 & 1046
\end{tabular}

Rezultati se generalno dobro poklapaju i daju još jednu potvrdu o adekvatnom korištenju konceptualnog modela u procjeni režima otjecanja u kršu. No treba spomenuti da se greška modela uočila kod izvora Tihaljina - ukoliko se promatraju odnosi godišnjih padalina sa MS Imotski u odnosu na izvor Tihaljina, model procjenjuje dva do 2.7 puta veću površinu. Razlog tome možda leži u lošoj korelaciji $\left(\mathrm{R}^{2}=0.49\right)$ između stanice Imotski i VS Peć Mlini. Koeficijenti otjecanja su viši za Opačac, Grudsko vrelo i Tihaljinu - između 0.6 i 0.7 te vjerojatno nešto manji $(0.5-0.6)$ za izvor Klokun.

Cilj izrade konceptualnog modela je istraživanje režima toka podzemne vode za krški izvore. Standardne metode identifikacije parametara hidrograma mogu pomoći u otkrivanju nekih od kompleksnih nelinearnih procesa koji se odvijaju s krškom podzemnom vodom i bile su korisne u postavljanju početnih parametara za model.

U ovom radu predložen je način izračuna kapaciteta uskladištenja podzemne vode krškog izvora u zabačenim područjima sa slabo razvijenom hidrološkom i meteorološkom mrežom. Jedini dostupni podaci su dali bolju sliku karakteristika bilance podzemnih voda krških izvora na slivu rijeke sa 8 imena - radi se o vodonosniku koji se sporo prazni (prosječni period recesije je dulji od 100 dana) s velikim kapacitetom skladištenja. Većina podzemne vode je akumulirana tijekom jesenskog i zimskog perioda (od rujna do veljače), a zatim slijedi recesijska krivulja gdje volumen pada na minimalne vrijednosti tijekom ljetnih mjeseci.

Raspodjela oborine i faktori krša se ne smatraju ni preciznima ni pouzdanima ali su svakako poboljšanje za analizu ovog područja. Jednostavni konceptualni model korišten u ovom slučaju se može prilagoditi brojnim drugim sličnim krškim sustavima zbog malog broja prilagođenih parametara što ga čini efektivnim alatom za procjenu bilance podzemne vode u kršu. Postupak korištenja linearnih rezervoara u opisu riječnog režima u kršu nije nov pristup u hidrološkom istraživanju, ali je njegova kombinacija s jednadžbom vodne bilance i modelom vlage u tlu omogućila bolje razumijevanje sustava iako rezultati nisu optimalni. Također, predložena metoda pred-procesiranja podataka (analiza recesije i separacija baznog otjecanja) je doprinijela ključnim ulaznim parametrima koji su zatim potvrđeni kalibracijom. 
Važno je naglasiti da se nekonzervativne i vremenski promjenjive komponente u bilanci podzemnih voda još uvijek smatraju procjenama jer ne postoji direktno mjerenje analiziranih komponenti vodne bilance osim oborine i protoka.

\subsection{Parametarski model}

Prema kategorizaciji modela otjecanja u hidrologiji (Watts, 1997; Todini, 1988) parametarski svedeni model neuralne mreže (eng. artificial neural network - ANN) prikazuje otjecanje u slivu kroz jednu modelsku jedinicu vršeći matematičke transformacije ulaza u izlaze kao konačni osrednjeni odgovor sustava. Uzročno, korištenje ANN-a ne traži detaljno razumijevanje fizikalnih karakteristika sustava niti ekstenzivnu predobradu podataka pa se teoretski mogu koristit za obradu nepotpunih, dvosmislenih podataka opterećenih šumom (Maier i Dandy, 1996). Hidrološka istraživanja u područjima gdje su mjerenja diskontinuirana, nesigurna u smislu točnosti prikaza $\mathrm{i} / \mathrm{ili}$ nepostojeća predstavljaju problem koji je često adresiran $u$ dosadašnjim istraživanjima (Dawson et al. 2006; Aziz et al. 2010; Besaw et al. 2010; Chen et al. 2010; Nourani et al. 2012). Količina potrebnih podataka i njihova obrada, tip, optimalna struktura, način određivanja pogreške, brzina učenja (Sarle, 1995; Thirumalaiah i Deo 2000; Maier i Dandy, 2000; Dawson i Wilby, 2000; Wu et al. 2009; Maier et al. 2010) - samo su neke od dodatnih poteškoća koje istraživanje mora adresirati. Posebni interes se daje fenomenu dvojakog režima tečenja u kršu (Kong-A-Siou et al. 2012; Johannet et al. 2008) te može li unutarnja struktura ANN-a replicirati ovakvo ponašanje. Često je u literaturi naveden problem black-box modela gdje ekstrapolacija novih saznanja nije moguća. Novija istraživanja teže upravo suprotnom - transparentniji prikaz rada neuronskih mreža.

Umjetna neuralna je familija statističkih algoritama učenja inspirirana ponašanjem bioloških neuronskih mreža. ANN vrši procjenu funkcije na velikom broju podataka gdje su ulaznoizlazne veze generalno nepoznate. Struktura ANN-a je predstavljena kao sistem tzv. neurona koji računaju utjecaj ulaznih podataka na izlaznu funkciju pomoću dodijeljenih težinskih faktora.

Glavne karakteristike neuronske mreže iskazuju se ponajprije u mogućnosti preslikavanja ulazno-izlaznih podataka. ANN uče na primjerima - sustav se može trenirati na poznatim primjerima prije sposobnosti zaključivanja sa nepoznatim primjerima, što dovodi do generaliziranja rješenja $\mathrm{ANN}-\mathrm{a}$ jer mogu predvidjeti nova rješenja na osnovi prijašnjih trendova. Sustav ANN-a je robustan i tolerira greške, čime su mjereni podaci neminovno opterećeni. ANN je u stanju velikom brzinom procesirati paralelne i raspodijeljene informacije (Jha, 2007). 
Iako su se neuronske mreže pokazale kao svestran mehanizam za modeliranje različitih procesa otjecanja (Maier i Dandy, 2000; ASCE, 2000a; ASCE 2000b; Dawson i Wilby, 2001) te svoju efikasnost u prognoziranju riječnih tokova (Campolo et al. 1999; Hsu et al. 1995; See i Openshaw, 2000) i kvalitete vode (Diamantopoulou et al. 2005; Maier et al. 2010) i dalje postoji zabrinutost u hidrološkoj zajednici o korištenju ANN-a kao svojevrsnoj slijepoj ulici. Ne postoje objektivne upute u modeliranju strukture aplikacija (iako isto vrijedi i za konvencionalne hidrološke modele), slaba je upućenost $u$ intervalima pouzdanosti prognoza riječnog toka te se do sada davalo malo značenja "izvlačenju" znanja iz načina učenja neuronskih mreža. Bitno je stoga proučiti unutarnje ponašanje i odrediti da li transformacija ulaznih podataka kao i specifična arhitektura mreže mogu korespondirati fizičkim elementima svedenog modela bilance voda. Cilj izrade modela ANN-a jest da se pomoću mjerenih klimatskih karakteristika i prethodnih izmjerenih otjecanja kvalitetno prikaže nelinearna veza padalina i otjecanja te uz transformaciju ulaznih podataka ispita kvaliteta odgovora modela a samim time i prezentira novi hibridni ANN model. Testiranjem različitih tipova mreža moguće je modelirati više ulaznih jedinica - vodomjernih stanica, a korištenjem vremenskog odmaka moguće je, sa statistički dovoljnom točnosti (Artigue et al. 2012) utvrditi i buduće otjecanje. Izazov koji predstoji istraživanju, osim pravilnog odabira tipa i arhitekture mreže, je i način predobrade ulaznih podataka za ANN, odabir odgovarajućeg algoritma učenja, kontrola rada mreže (samoučeća ili nadzirana) te na kraju ekstrapolacija znanja o fizikalnom procesu koji se opisuje iz neuronske mreže.

Neuronske mreže posjeduju niz svojstava koja ih čine više nego prihvatljivim rješenjem za čitav niz problema. Među najvažnije spadaju:

- Učenje - obzirom na razliku između odziva mreže i željenog odziva moguće je odrediti pogrešku i korekciju parametara mreže tzv. učenje pod nazorom. Moguće je i učenje bez nazora prema samo-organizirajućim mapama (eng. self organizing map - SOM)

- Univerzalni aproksimator - aproksimacija bilo koje kontinuirane funkcije sa relativnim stupnjem točnosti

- Nelinearnost definirana svojstvom neurona tj. aktivacijske funkcije koju koristi

- Generalizacija - pamćenje funkcije preslikavanja omogućuje rješavanje primjera koji nisu predočeni mreži za vrijeme treniranja

Navedene karakteristike omogućile su stvaranje velikog broja različitih vrsta ANN-ova, ponajviše zbog interesa za njihovu uporabu u raznim znanstvenim područjima. Najpoznatiji i najčešće korišteni tipovi su: višeslojni perceptron (MultiLayer Perceptron - MLP), neuronske 
mreže s prijenosnom funkcijom radijalne baze (RBF - Radial Basis Function), samoorganizirajuće mape (SOM), GRNN (Generalized Regression Neural Networks), RNN (Recurrent Neural Networks), SVM (Support Vector Machines), TNN (Temporal Neural Networks), Neuro-fuzzy mreže i dr.

Osnovna struktura mreže je višeslojni perceptron tj. umjetni neuron koji u $j$-tom odzivu računa vrijednost funkcije $f\left(x_{j}\right)$ :

$$
f\left(x_{j}\right)=f\left[\alpha_{j}+\sum_{i=1}^{k}\left(w_{j} y_{j}\right)_{i}\right]
$$

Gdje je:

$\sum_{i=1}^{k}\left(w_{j} y_{j}\right)_{i}-$ suma otežanih $(w) i$ ulaza $y$

$f$ - aktivacijska funkcija neurona, tipično sigmoidna

$\alpha_{j}$ - bias/treshold - omogućuje pomicanje vrijednosti aktivacijske funkcije (npr. iz $0 \mathrm{u}$ neku drugu vrijednost); vrijednost koja se mora postići da bi se ostvarila određena reakcija, u ovom slučaju aktivacija neurona (Slika 3.21.).

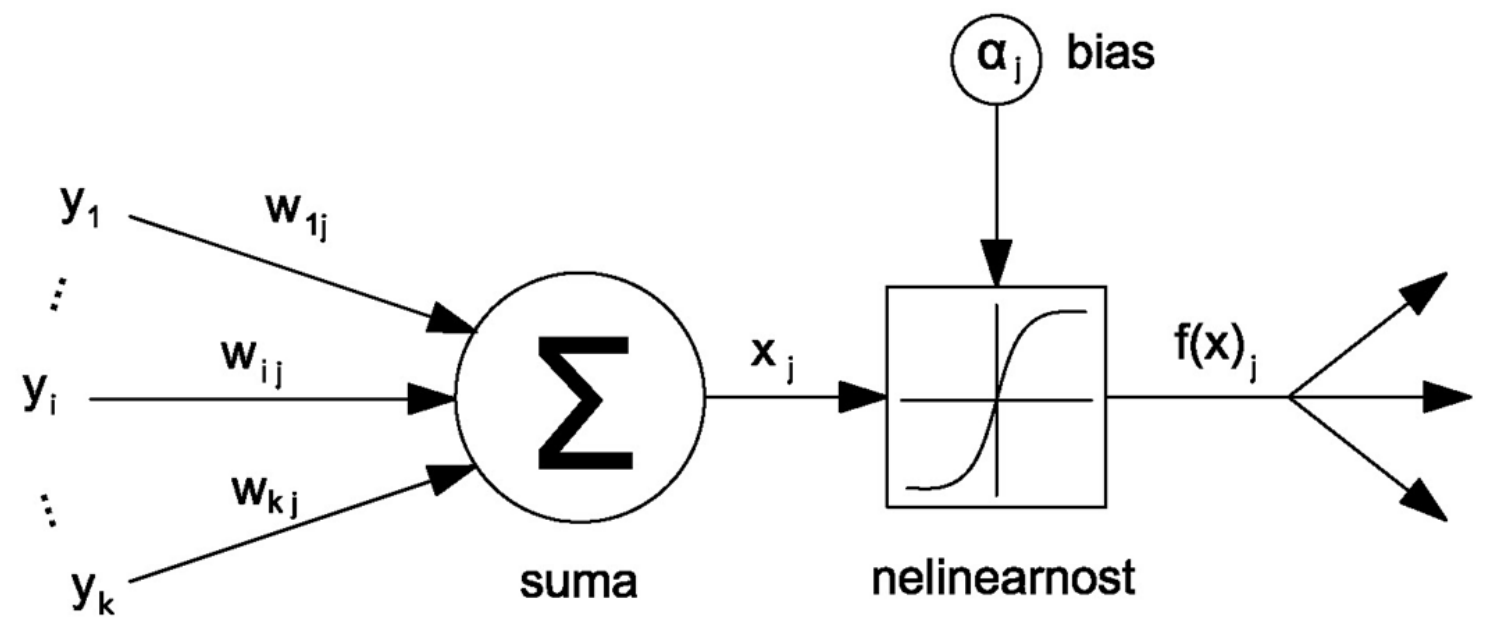

Slika 3.21. Osnovna struktura neuralne mreže

Najčešće korišteni statistički algoritam učenja neuralne mreže je propagacija greške unatrag (eng. error backpropagation - BP). BP rasprostire ulazni signal u mrežu prema izlazu, a zatim se u izlaznom sloju računa pogreška $e_{k}^{j}$ u k-tom koraku (Slika 3.22.). Željeni odziv je poznat pa je greška izlaznog $j$-tog neurona razlika željenog odziva - $\operatorname{target}_{k}^{j}$ i izlaza - output $o_{k}^{j}$ :

$$
e_{k}^{j}=t_{k}^{j}-o_{k}^{j}
$$




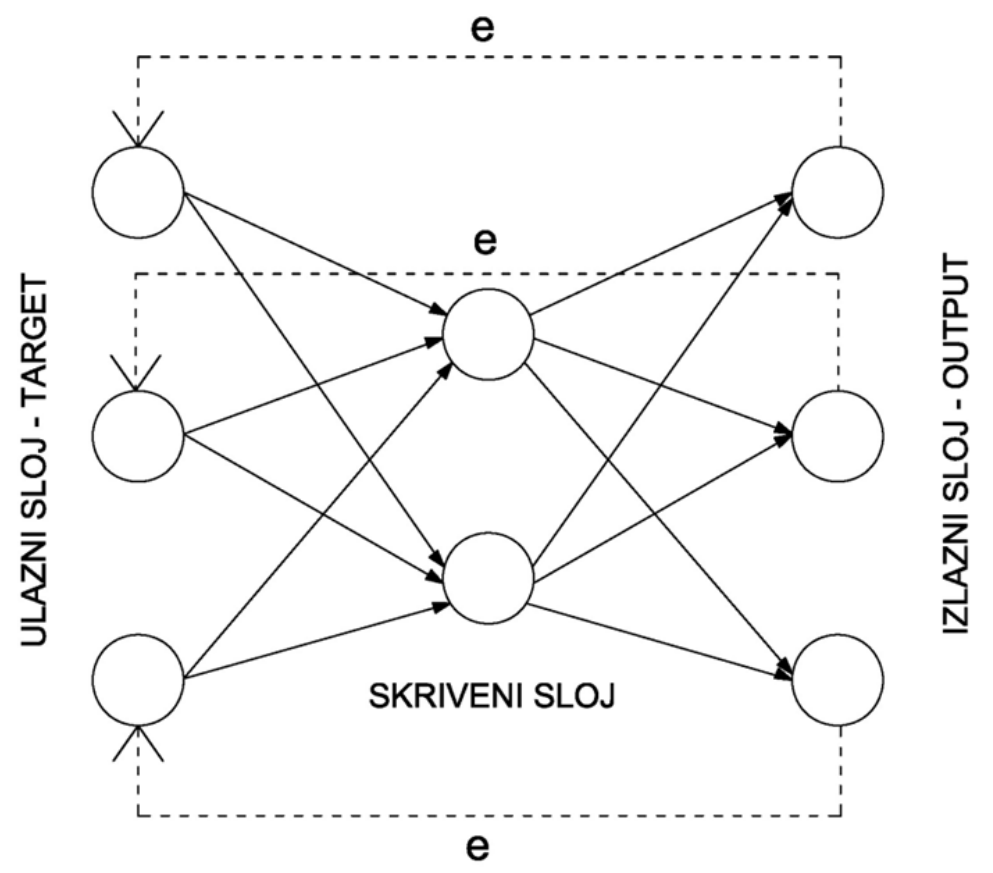

Slika 3.22. Funkcioniranje algoritma propagacije greške unatrag

Svaki ulaz $y$ mreže umnožen je sa određenom težinom $w$ pa se optimalno rješenje ANN-a dobiva upravo podešavanjem težina:

$$
\Delta w_{k}=\alpha \cdot \Delta w_{k-1}-\eta \cdot \delta_{k} \cdot o_{k}
$$

Izraz (3.33.) naziva se delta pravilo te ovisi o:

$\eta$ - brzini učenja

$\delta_{k}^{j}$ - lokalnom gradijentu izlaza $o_{k}$

$\alpha$ - momentu koji omogućuje smanjuje/povećanje iznosa promjene težinskih koraka u odnosu na prethodne - omogućava brže spuštanje ka minimumu u područjima sa malim gradijentom i izbjegava oscilacije u slučaju promjene smjera (Slika 3.23.)
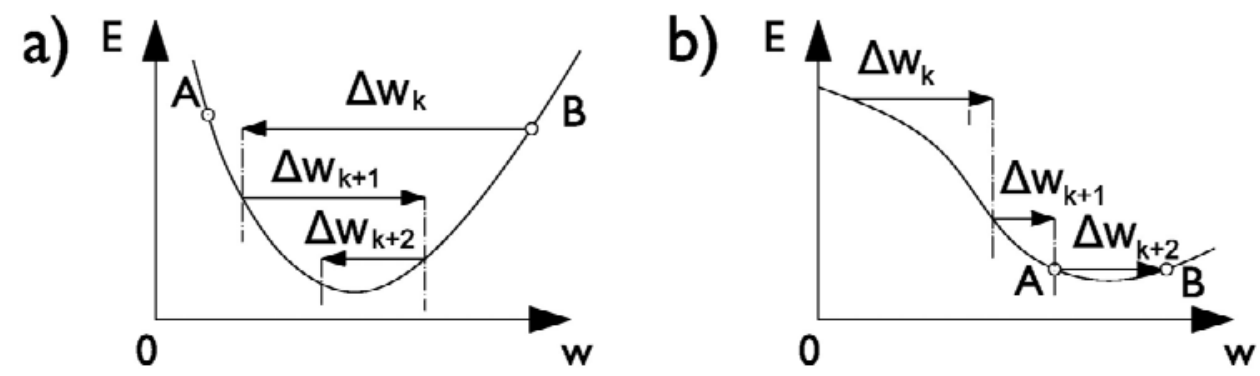

Slika 3.23. Promjena veličine težina: a) promjena smjera i b) brže spuštanje ka minimumu Izravnija potraga za minimumom funkcije pogreške omogućuje korištenje algoritama drugog reda kao što je Levenberg-Marquardt algoritam (LM). LM je metoda učenja posebno razvijena 
za ANN i predstavlja specijalan slučaj Gauss-Newtonove metode koja pomoću Jacobian matrice prvih derivacija pogreške određuje težinu $w$ u koraku $k+1$ :

$$
\mathrm{w}_{k+1}=\mathrm{w}_{k}-\left(\mathbf{J}^{T} \cdot \mathbf{J}+\mu \cdot \boldsymbol{I}\right)^{-1} \cdot \mathbf{J}^{T} \cdot \mathbf{e}
$$

Glavnu razliku čini parametar $\mu$ koji po potrebi povećava ili smanjuje funkciju pogreške u koraku $k$. LM je stoga za veće $\mu$ iznose sličniji gradijentnom algoritmu a za manje GaussNewtonovoj metodi.

\subsubsection{Postojeća saznanja u istraživačkom području}

Razvoj umjetnih neuronskih mreža započeo je otprilike prije 50ak godina kada su McCulloch i Pitts (1943), inspirirani željom da razumiju funkcioniranje ljudskog mozga, razvili prve algoritme. Istraživanja u ovom polju su stagnirala neko vrijeme, ponajviše zbog nemogućnosti izvršavanja osnovne XOR petlje (XOR petlja - ekskluzivna disjunkcija) i dugog vremena rada za proračun velikih mreža. Povećanjem snage procesora računala kao i razvoj BP algoritma vratilo se zanimanje za ovu vrstu paralelnog distribuiranog procesiranja podataka. Značajan interes za ovu vrstu računalne mehanike je porastao nakon što su Rumlehart et al. (1986) razvili iscrpan teoretski okvir za neuronske mreže. Uporaba ANN-ova se intenzivirala u svim poljima inženjerstva i znanosti, s tim da su hidrološka istraživanja, sa neuronskim mrežama kao glavnim računskim alatom, povećana tek u 90-tima.

Primjena neuronskih mreža unutar područja hidrologije, započinje ponajprije sa analizom hidroloških i hidrauličkih vremenskih serija (Hsu et al. 1995; Raman i Sunilkumar, 1995; Campolo et al. 1999; Govindaraju i Ruo, 2000; Hu et al. 2001; Lohani et al. 2012) koje su najčešće i jedine informacije koje su dostupne za vodonosnike. Zavisno o ograničenjima podatka, razvijaju se različiti tipovi i strukture mreža za predviđanje površinskog otjecanja (Dawson et al. 2002; Rajurkar et al. 2002; Kumar et al. 2004; Piotrowski et al. 2004; Raid et al. 2004; Suhaimi i Bustami, 2009) kao i za predviđanje budućih otjecanja (See i Openshaw, 2000; Wu et al. 2005; Kurtulus i Razack, 2006; Biswas, 2008; Akhtar et al. 2009; Roy et al. 2010). Neuronske mreže su uspješno koriste i kod slučajeva nadopunjavanja isprekidanih vremenskih serija (Nourani et al. 2012; Raghunathan, 2004; Honaker i King, 2010; Dastorani et al. 2010) ali i na područjima gdje nedostaju klimatološka ili hidrološka mjerenja (Besaw et al. 2010; Chen et al. 2010; Artigue et al. 2012; Heng i Suetsugi 2013).

Problem modeliranja odnosa padalina i otjecanja je ipak stvorio najviše zanimanja kod istraživača modela neuronskih mreža. Nelinearna struktura, dostupnost povijesnih zapisa i mjerenja, fizikalna kompleksnost modela; neki su od faktora koji su rezultirali da istraživači 
traže nova alternativna rješenja, a ANN su bili logičan odabir. Istraživačka aktivnost sa ovog aspekta razotkriva mnogo te se generalno može klasificirati u dvije kategorije. Prva kategorija su studije gdje su ANN trenirane i testirane na postojećim modelima (Raman i Sunilkumar, 1995; Smith i Eli, 1997) koje su dale osnove za demonstriranje ponašanje modela, u slučaju kada postoji dovoljan broj podatka za treniranje. Ovakvi uvjeti su lako ostvarivi, pošto se potrebni podaci relativno jednostavno mogu generirati sa današnjim računalima. $U$ ovakvim istraživanjima, performanse ANN-ova su u najboljem slučaju jednaki izvornom modelu. Većina ANN-baziranih studija pada u drugu kategoriju - korištenje mjerenih podataka o padalinama i otjecanjima. Često se uz ove ulaze koriste i dodatne varijable kao temperatura, količina otopljenog snijega, izmjerena evaporacija i slično. Analiza mjerenim podacima daje razumljiviju procjenu rada neuralne mreže čime ona postaje važna karika u poboljšavanju kvalitete modela otjecanja.

Dawson i Wilby (2001) jedni su od značajnijih autora koji su postavili osnovni okvir za modeliranje otjecanja uz pomoć neuronskih mreža, procjenu tehnika predviđanja protoka (Dawson et al. 2002) te detektirali konceptualni model u procesima unutar neuronske mreže (Wilby et al. 2003). U većini slučajeva ANN se koriste kao aplikacija uz par dodatnih modifikacija (Riad et al. 2004; Suhaimi, 2009; Toukourou et al. 2011; Sarkar, 2012) i/ili usporedba sa poznatim klasičnim i konceptualnim modelima (Rajurkar et al. 2002; Lallahem i Mania, 2003; Rahnama i Barani, 2005; Senthil Kumar et al. 2005; Ghumman et al. 2011; Saharia i Bhattacharjya, 2012). Kao što Abrahart et al. 2012 prikazuju, posljednjih 2 desetljeća su se razvili različiti trendovi i tematske grupe bazirane na aktivnostima koje su zabilježene $u$ člancima sa tematikom otjecanja i neuronskih mreža. Prvenstveno to je tehnički razvitak mreža u smislu proširenja osnovnog MPL modela u strukturi mreže sa propagacijom greške unaprijed (eng. feedforward neural network - FFNN) uz korištenje popularnih algoritama kao što su BP, Levenberg-Marquardt ili Conjugate Gradient Descent (Hsu et al. 1995; Shamseldin, 1997; Smith i Eli, 1997).

Istraživanja neuronskih mreža uključuju kombiniranje fuzzy (eng. fuzzy - neizrazit) sistema skup inteligentnih metoda koji se za razliku od klasičnog računarstva temelje na približnom izračunavanju i zaključivanju, samoučenju, paralelizmu i nedeterminizmu. Fuzzy sistemi (eng. neuro fuzzy system - NFS) i ANN zajedno generiraju pravila optimizacije parametara i u teoriji mogu objasniti fundamentalne procese u vodonosnicima (Bazartseren et al. 2003; Nayak et al. 2004; Wu et al. 2010). Maier i Dandy (2000) žustro zagovaraju korištenje NFS u hidrološkim modeliranjima. Kombinacija ANN sa evolucijskim i genetskim algoritmima (GA) rezultirala je u produktu nazvanom neuro-genetski sistemi koji su zajedno za fuzzy sistemima pojavili 
početkom 90tih u istraživanima. Hsu je (1995) pokazao da se bi se ANN mogla poboljšati uključivanjem različitih optimizacijskih procesa, uključujući genetske algoritme. Broj zabilježenih studija je manji najvjerojatnije zbog nedostatka računalnih platformi za implementaciju. Većina aplikacija se koristi za predviđanje otjecanja ili razina voda kao hibridna verzija ANN-a (Rao i Jamieson, 1997), iako se GA mogu koristiti kao algoritam treniranja ANN (Jain i Srinivasulu, 2006), a u nekim slučajevima određuju optimalnu strukturu neuronske mreže (Chen i Chang, 2009).

Prema ASCE (2000a, 2000b) osim modeliranja protoka, ANN je u hidrologiji je našao široko zanimanje kod istraživanja procjene količine kiše (Raman i Sunilkumar, 1995; Hong et al. 2004; Wu et al. 2010; Nourani et al. 2008; Bustami et al. 2007; Kim i Pachepsky, 2010; Gadgay et al. 2012), ispitivanjima podzemnih vodonosnika (Lallahem i Mania, 2003; Parkin et al. 2007; Daliakopoulos et al. 2005; Garcia i Shigidi 2006; Opsahl et al. 2007; Chitsazan et al. 2013; Maiti i Tiwari, 2013) i kvalitete vode (Diamantopoulou et al. 2005; Girija et al. 2007; Gibbs et al. 1999; Ay i Kisi 2014). Ostale aplikacije neuronskih mreža na riječnim bazenima moguće je vidjeti i kod procjene vlage u tlu (Ogaja, 2006; Ahmad et al. 2010), evaporacije iz tla (Johannet et al. 2008; Deswal i Pal, 2008; Chung et al. 2012) kao i procjenu riječnog sedimenta (Heng i Suetsugi, 2013; Haghizade i Goudarzi, 2010). Neuralna mreža kao univerzalni procjenitelj funkcije koristan je kod modeliranja problema gdje se relacija nezavisnih i zavisnih varijabli slabo poznaje - kao kod problema procjene parametra propusnosti (Samani et al. 2007; Ajmera i Rastogi, 2008; Chitsazan et al. 2013) i zaslanjenosti (Seyam, 2011) u podzemnim vodonosnicima.

Kao jedan od glavnih ciljeva preglednih radova (Maier i Dandy, 2000; ASCE 2000a i 2000b; Abrahart et al. 2012) navodi se implementacija fizikalnih saznanja u modele razvijene neuronskim mrežama. Posebni interes je na heterogenim krškim akviferima koji potiču razvoj sistemskog pristupa problemu. Takve studije uzimaju u obzir varijabilnost padalina mjerene na različitim kišomjernim stanicama. Trenutno, konceptualni modeli imaju problem identifikacije nelinearnih ponašanja, no Abrahart (2012) sugerira, kao i prethodno navedeni radovi, da se zbog mogućnosti efikasnog modeliranja hidroloških procesa pomoću ANN-a otvara novo zanimljivo područje istraživanja interpretacije i razumijevanja black box sistema. Wilby et al. 2003 su napravili prva hidrološka ispitivanja ovog tipa gdje se korištenjem kvantitativnih i kvalitativnih metoda mogu utvrditi procesi u skrivenim slojevima neuronske mreže kao što su brzi i spori tok i nivo vlažnosti tla. Malo kasnije, Jain et al. (2004) izvještava o identifikaciji fizikalnih procesa. Većina radova koja obrađuju tematiku krša koristi tzv. klasične neuronske mreže za predviđanje otjecanja (Lallahem i Mania, 2003; Kurtulus i Razack, 2006; Sepúlveda, 2009; Paleologos et al. 
2013). Najnovija istraživanja se posvećuju implementaciji ANN kao poboljšanje postojećih modela i to bilance voda u kršu (Kraller et al. 2012) kao i sistemskom pristupu kontrole dizajna modela (Kong-A-Siou et al. 2011), stoga je nužna analiza primjene ovakvih modela na lokalnim krškim slivovima.

\subsubsection{Kontrola kompleksnosti i procedura dizajna}

Obrada ulaznih podataka jedan je od najvažnijih koraka razvoja modela kojem se generalno daje malo pažnje (Maier et al. 2010). Odabir i redukcija dimenzije podataka se tipično vrši na ad-hoc bazi i generalno se reflektira na prijašnja saznanja iz hidrologije ili su ograničeni dostupnošću istih (Campolo et al. 1999; Thirumalaiah i Deo, 2000). Vrlo malo istraživanja (Maier et al. 2010) koristi nelinearne metode za selekciju ulaza u model; u većini slučajeva linearna korelacija $i$ kroskorelacija je korištena statistika te se postavlja u pitanje prikladnost ovakvog odabira. Ipak obrada podataka, pogotovo dugih vremenskih nizova (Maier i Dandy, 2001; Singh et al. 2010) omogućuje da ANN uči ukoliko je prezentirana sa određenim prethodno odabranim segmentima. U obzir se mora uzeti i obrada šuma (Elshorbagy et al. 2002) te da li će njegovo uklanjanje uzročiti kaotično ponašanje podataka.

Pregledni radovi (Maier i Dandy, 2000; Maier et al. 2010) ističu dobra svojstva predviđanja umjetnih neuronskih mreža ali i naglašavaju nedostatak sustavno pristupa formiranju neuronskog modela za hidrološke analize. Iako je nedostatak zamijećen već duži niz godina i dalje postoji potreba za razvojem robusnog pristupa. Stoga se važni koraci u postupku formiranja modela, poput određivanje broja i vrste ulaza, podijele podataka, izbora strukture i broja neurona određuju bez jasno naznačene metode, najčešće u vidu sistema pokušaj-pogreška (eng. trail and error) ili slučajnim odabirom. Sustavni pristup prikazan na Slici 3.24. predstavlja metodu formiranja modela sa unaprijed definiranim koracima. Pri tome se svaki korak može provesti na više različitih načina čime se daje fleksibilnost istraživaču da obzirom na raspoloživu bazu podataka ocijeni optimalnu metodu za izvršavanje koraka modeliranja. S obzirom na veliku fleksibilnost ovaj postupak doprinosi kvaliteti istraživačkog rada a u konačnici i kvaliteti formiranog modela. U nastavku će se opisati potrebne radnje za svaki korak sustavnog oblikovanja ANN-a. 


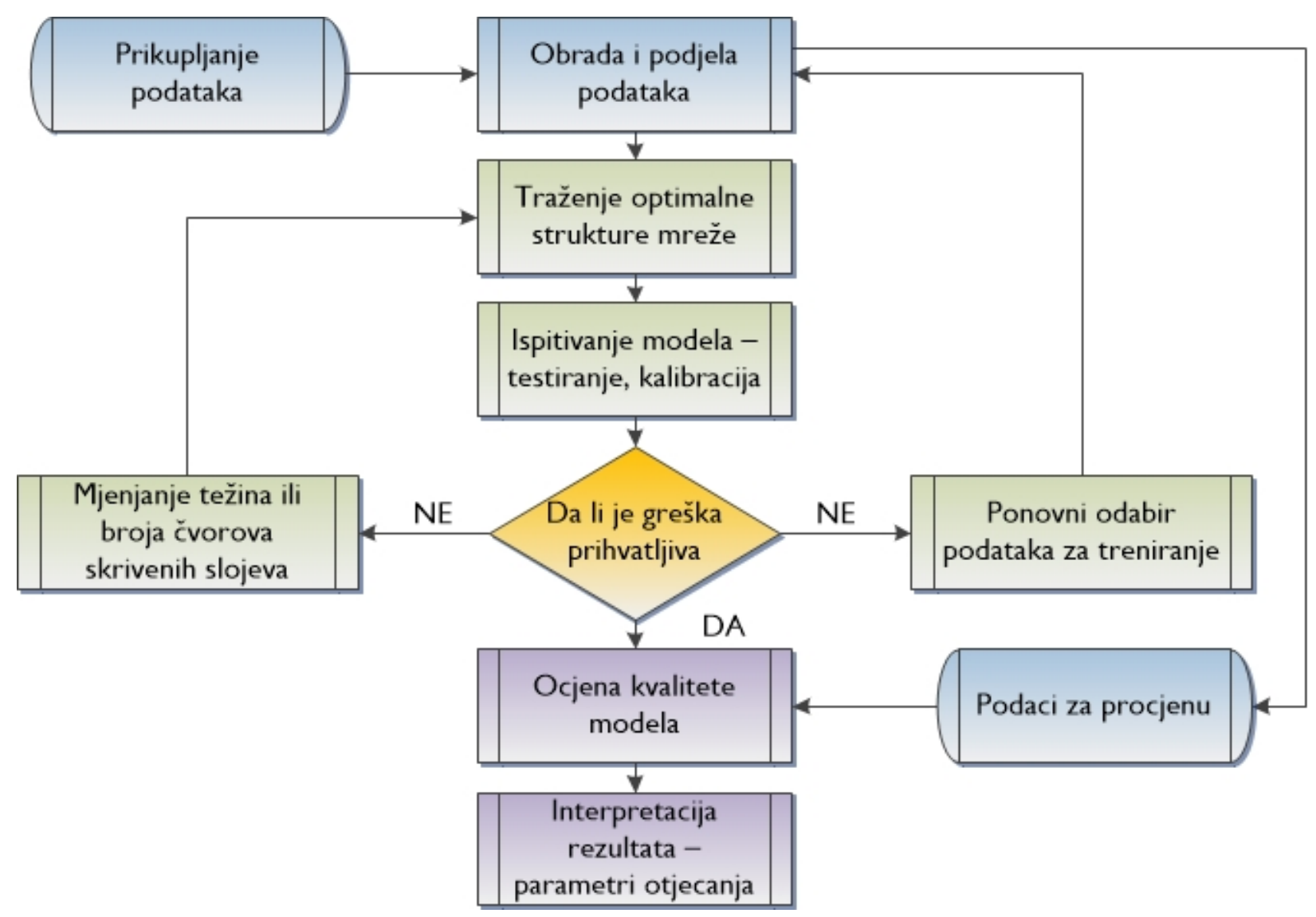

Slika 3.24. Postupak oblikovanja modela neuralne mreže

\section{Predkorak - prikupljanje podataka}

Provedeno je prikupljanje podataka o otjecanjima i klimatološkim karakteristikama na području krškog sliva smještenog na koordinatama $43^{\circ} 05^{\prime}$ i $43^{\circ} 60^{\prime}$ sjever, te $17^{\circ} 00^{\prime}$ i $17^{\circ} 60^{\prime}$ istočno koji obuhvaćaju vremenski period od 1990. do danas. Detaljna obrada prikupljenih podataka obrađena je u 2. poglavlju te je zaključeno da će fokus oba modela biti na stanicama koje su na ili neposrednoj blizini krških izvora. Razlog ovome je dvojak: s jedne strane, vodomjerne stanice kraj izvora imaju dovoljno kvalitetne nizove podataka za kalibraciju i simulaciju modela, a s druge strane su definitivno najvažnije za vodno-gospodarsku sliku promatranog područja pošto se u krški izvori jedini način opskrbe vodom na slivu rijeke sa 8 imena.

\section{Korak-obrada i podjela podataka}

Pravilno selektirani podaci ishod su postavljene funkcije cilja modela. Ona varijabla koja je od posebnog značaja, a može se definirati kao funkcija ostalih varijabli iz skupa raspoloživih podataka biti će cilj modela i izlaz neuronskog modela. Općenito, model može imati više izlaza $\mathrm{u}$ obliku trenutnih vrijednosti različitih varijabli u određenom trenutku $t$ ili vremensku seriju jedne varijable predviđene za $t+k$, gdje je $k=1,2, \ldots n, n \in N$. Skup raspoloživih podataka su diskretne mjerene vrijednosti zabilježene $u$ određenom vremenskom periodu sa dnevnom frekvencijom prikupljanja uzoraka stoga je i korak računanja dnevni. 
Za prikupljene podatke provedena je statistička analiza njihove međusobne ovisnosti korelacijskom analizom kroz modele jednostavne linearne regresije i spektralnom analizom. Predviđanje vrijednosti varijable hidrološkog sustava temelji se na vremenskoj seriji stoga je spektralna analiza koristan alat za određivanje zaostajanja ulaznih varijabli (lags), odnosno odgovarajući broj uzastopnih uzoraka ulaznih varijabli koji imaju značajan utjecaj na trenutnu vrijednost izlazne varijable. Ranija istraživanja (Maier i Dandy, 2000) smatrala su da ANN mogu samostalno odrediti važnost pojedinih varijabli pa se njihovom izvoru nije davala velika pozornost. No, uporaba velikog broja ulaznih varijabli rezultiralo je često neučinkovitost $\mathrm{i}$ pretreniranosti modela. Odabrane ulazne i izlazne varijable te njihova dužina predstavljeni su u Tablici 3.17. Dužine vremenskih serija određene su prema rezultatima konceptualnog modela. Kalibracijski set prema Tablici 3.17. za ANN u omjeru 70-15-15 koristi za treniranje, validaciju i testiranje samog modela. Iako je time izvršena jedna validacija, preporučljivo je da se ona izvrši na setu podataka koji nije prezentiran mreži tokom učenja - stoga je formiran period tzv. krosvalidacije gdje se na neovisnom setu vrši simulacija i ispituju statistički pokazatelji za ocjenu kvalitete.

Tablica 3.17. Izbor podataka za kalibraciju modela i neovisni krosvalidacijski period

\begin{tabular}{lcc}
\multicolumn{1}{c}{ Izvor } & Period kalibracije & Period krosvalidacije \\
\hline Opačac & $1.1 .1995-31.12 .2001$ & $1.1 .2002-31.12 .2010$ \\
Grudsko vrelo & $1.1 .2006-31.12 .2008$ & $1.1 .2009-31.12 .2010$ \\
Tihaljina & $1.1 .1990-31.12 .1996$ & $1.1 .1997-31.12 .2002$ \\
Klokun & $1.1 .1995-31.12 .2002$ & $1.1 .1990-31.12 .1991$
\end{tabular}

Priprema podataka uključuje i predobradu normalizacijom te podjelu na pod-setove za ispitivanje modela (trening, kalibracija) te neovisni set za procjenu kvalitete modela. Podjelu je potrebno izvršiti tako da pod-setovi imaju iste (ili ako nije moguće) slične statističke karakteristike.

Najjednostavniji i najčešće korišteni način obrade podataka jest linearna transformacija (jednadžba 3.28) u kojoj se neka varijabla $x_{i}$ može razmjerno prikazati iz intervala $\left[\mathrm{x}_{\min }, \mathrm{x}_{\max }\right] \mathrm{u}$ novi interval $\left[\mathrm{x}_{\text {low }}, \mathrm{x}_{\text {high }}\right]$ pri čemu se osigurava ravnopravnost svih ulaznih varijabli. Linearna transformacija varijable $x_{i}$ može se izvršiti i prema standardiziranoj vrijednost uz pomoć srednje vrijednosti i standardne devijacije. Pošto je korištena aktivacijska funkcija neuralne mreže na intervalu $[-1,1]$ podaci će se transformirati na ciljani vektor u granicama $[0.1,0.9]$ kao i kod konceptualnog modela da se zadrži dosljednost. Razlog smanjivanju ekstrema aktivacijske funkcije jest izbjegavanje usporavanja treniranja mreže i saturiranja podataka u gornjim i donjim granicama (Wilby et al. 2003). 


\section{Korak-arhitektura mreže}

Određivanje arhitekture mreže predstavlja jedan od važnijih koraka formiranja modela jer će o njemu ovisi ostali koraci sustavnog pristupa. Višeslojni perceptron (MLP) sa svojstvom univerzalnog procjenitelja koji koristi nelinearnu (sigmodalnu) aktivacijsku funkciju u skrivenom sloju i linearnu aktivacijsku funkciju u izlaznom sloju predstavlja najčešće korištenu arhitekturu za modeliranje hidroloških sustava. No, korisnike ovakvih modela se upozorava na osnovne odluke koje se moraju donijeti prilikom odabira prikladne klase modela (Abrahart et al. 2005). To su ponajprije:

- karakteristike čvorova mreže kao procesne jedinice

- topologija mreže npr. način povezivanja čvorova

- algoritam učenja

Broj mogućih kombinacija i permutacija koji se može implementirati je enorman te je sveobuhvatna analiza nepraktična. Međutim, za hidrološke potrebe modeliranja, tri najčešća alati $\mathrm{su}:$

a) BPNN - neuronska mreža sa propagacijom unazad

b) RBFN - neuronska mreža sa radijalnom baznom funkcijom

c) SOFM - samo-organizirajuće karte značajki

Ukoliko promatramo otjecanje kao nelinearni sustav koji prima određeni impuls u vidu padalina a odgovor sustava je zabilježeni protok očigledno je da će odgovor sustava trajati više od jednog impulsa - time je definirana dinamička karakteristika modela u vidu mreže koja ima određenu memoriju. Odgovor u bilo kojem vremenskom koraku ne ovisi samo o trenutnom ulazu već o sekvenci prošlih ulaza. Ako se konstruira mreža koja nema povratne veze, samo konačna količina memorije utječe na odgovor sustava. NARX (Nonlinear Autoregressive Recurrent with eXogenous inputs) je nelinearna autoregresivna periodična mreža sa egzogenim ulazom specifično dizajnirana (Demuth i Beale, 2004) za modeliranje vremenskih serija na temelju dosada korištenih autoregresivnih modela vremenskih serija koji se često koriste u hidrologiji. Istraživanja (Diaconescu, 2008) pokazuju da su NARX mreže bolje u otkrivanju dugoročnih ovisnosti unutar vremenske serije nego obične neuralne mreže sa povratom vezom a razlog tom leži u načinu računanja BP algoritma učenja. Jednadžba koja definira NARX model:

$$
y(t)=f\left(y(t-1), y(t-2), \ldots, y\left(t-n_{y}\right), u(t-1), u(t-2), \ldots, u\left(t-u_{n}\right)\right)
$$

traži vrijednost slijedeće ovisne izlazne varijable $y(t)$ kao povrat prethodnih vrijednosti izlazne varijable i povrat neovisne (egzogene) ulazne varijable $u(t)$. Postoje mnoge aplikacije NARX 
mreže: može se koristiti kao prediktor slijedeće vrijednosti ulaznog signala, kao nelinearni filter koji pretvara izlazni željeni signal u ulazni i smanjuje mu šum, no osnovna preporuka je korištenje u modeliranju nelinearnih dinamičnih sistema. NARX u svojoj arhitekturi sadrži povratnu vezu zbog koje je izlazna varijabla dostupna mreži prilikom treniranja što omogućuje stvaranje serijski paralelne arhitekture (Slika 3.25.a). Time se stvarni izlaz umjesto procijenjenog prezentira mreži. Ova mogućnost daje prednost u vidu veće točnosti mreže i rezultira "čistom" propagacijom unaprijed, dok se statična povratna propagacija može koristit za treniranje (Slika 3.25.b). Signal ulazi s lijeva i prolazi kroz N-1 korak kašnjenja unutar TDL-a (eng. Tapped Delay Line) tj. N-dimenzionalnog vektora koji je sačinjen od vrijednosti signala u trenutnom vremenu, vrijednosti signala u prethodnom vremenu itd.
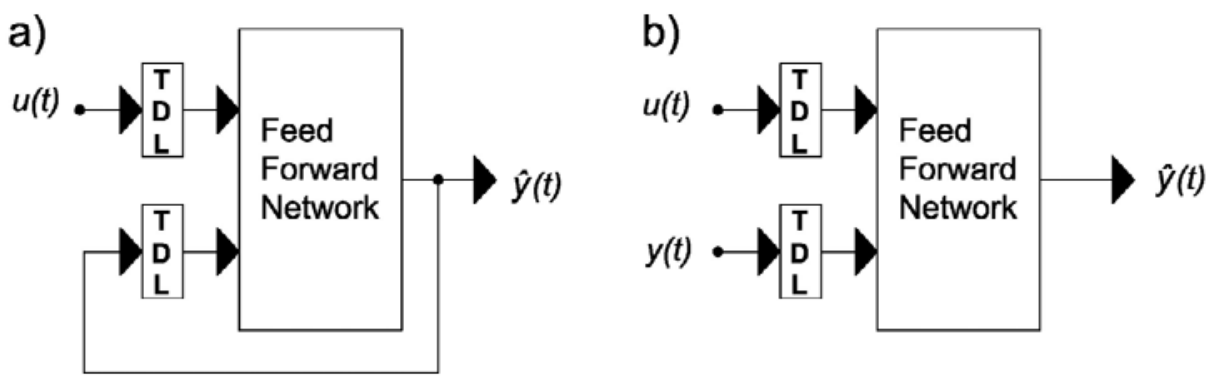

Slika 3.25. Arhitektura NARX mreže: a) paralelna i b) serijski paralelna

\section{Korak-ispitivanje i kalibracija}

Postupak ispitivanja modela provodi se u tri faze - podešavanje strukture, kalibracija te validacija modela. Postupak se ponavlja dok se ne odredi model sa najboljim uvjetima u odnosu na kriterije kvalitete. Podešavanje strukture se vrši odabirom optimalnog broja neurona skrivenog sloja radi ispravnog funkcioniranja modela. Preveliki broj neurona stvara i veliki broj parametara koji su skloni pretreniranju (eng. overfitting). Suprotno, mreža sa malim brojem neurona često nije u stanju prepoznati nelinearne odnose ulazno-izlaznih varijabli. Metoda preciznog i pouzdanog načina odabira potrebnog broja još nije određena. Određene preporuke postoje (Elshorbagy et al. 2002) za definiranje gornje granice prema broju ulaza neuronske mreže i broju uzoraka za treniranje. Određivanje broja neurona se uglavnom provodi metodom trial-and-error. Posljednja istraživanja upućuju na optimizacijske metode kao što je metoda sažimanja (eng. pruning method) - odabire se dovoljno velika mreža te se postepeno isključuju neuroni koji ne doprinose značajno rezultatu; te suprotna konstruktivna metoda koja kreće od minimalne strukture gdje se naglašava problem "zaglavljivanja" u lokalnim minimumima. U radu se koristiti konstruktivna metoda na način da se broj čvorova povećava sve dok performanse mreže na kros-validacijskom setu ne budu imale značajno poboljšanje. Broj 
čvorova određena je prema preporuci (Maier i Dandy, 2001) o limitu određenom prema broju ulaza u ANN:

$$
N^{H} \leq 2 N^{I}+1
$$

Restrikcija na jedan skriveni sloj bazirana je na izvještajima o marginalnom utjecaju na RR modele (Abrahart i See, 2000).

Daljnja faza ispitivanja modela je kalibracija gdje se podešavanjem parametara modela provodi sa odabranim algoritmom učenja te je konačan ishod skup vrijednosti za koje je pogreška, tj. funkcija cilja minimalna. Funkcija cilja može biti jedan ili više statističkih pokazatelja, a najčešće korišteni pokazatelji su srednja kvadratna pogreška (MSE) i suma kvadratne pogreške (SSE).

Prilikom kalibracije, korišteni lokalni algoritmi uzimaju skup nasumično odabranih vrijednosti parametara mreže. Time se stvara nova mogućnost zaglavljivanja u lokalnom minimumu te se preporuča kalibracija iz nekoliko početnih uvjeta (Abrahart et al. 2005). Globalni algoritmi rješavaju problem početnih uvjeta ali računalno zahtijevaju složeniji postupak.

Ispitivanje modela za vrijeme identifikacije tj. validacija provodi se pomoću jednog kriterija kvalitete $\mathrm{i}$ to one mjere koja se koristi kao funkcija cilja za potrebe kalibracije modela. Uobičajene mjere kvalitete kao funkcije cilja su već navedeni parametri MSE i SSE, dok se za mjeru kvalitete koristi veći broj mjera za procjenu apsolutne i relativne točnosti modela koje će biti opisane u 4. koraku.

Određivanje najboljeg modela, osim sa predstavljenim parametrima, moguće je testirati dodatnim scenarijima mijenjajući vrijeme kašnjenja i doprinos pojedinog dijela sliva tj. krških izvora koji su odabrani za ispitivanje. Time se želi ispitati mogućnost ANN-a da identificira dinamiku padalina nad različitim zonama sliva kao i različitu hidrodinamiku pojedine zone. U radu se ispituje doprinos vodomjerne stanice $u$ odnosu na vrijeme kašnjenja i međusobnu ovisnost članova vremenske serije otjecanja. Evaluacija korelacije između padalina i protoka izvršena je pomoću linearne kros-korelacije između odabranih meteoroloških i vodomjernih stanica te je vrijeme kašnjenja za svaki VS. Međusobna ovisnost tj. memorija sustava kod otjecanja određena je pomoću autokorelacijske funkcije (ACF) - utjecaj $t$ - $k$ koraka. Najznačajniji utjecaj na trenutnu vrijednost je očekivano vrijednost iz prethodnog koraka, nakon čega slijedi pad ovisnosti koja se smatra statistički neznačajna ispod vrijednosti ACF $=0.7$. Formiran je veći broj modela sa različitim brojem članova ulaznih vektora prema Tablici 3.18. za koji će se eksperimentalno utvrditi najbolji model za pojedinu vodomjernu stanicu. 
Tablica 3.18. Članovi ulaznih vektora za 4 krška izvora (4 ANN modela)

\begin{tabular}{lcc}
\multicolumn{1}{c}{ Izvor } & Članovi vektora protoka & Članovi vektora padalina \\
\hline Opačac & $\mathrm{Q}(\mathrm{t}-1), \ldots, \mathrm{Q}(\mathrm{t}-7)$ & $\mathrm{P}(\mathrm{t}-1)$ \\
Grudsko vrelo & $\mathrm{Q}(\mathrm{t}-1), \ldots, \mathrm{Q}(\mathrm{t}-20)$ & $\mathrm{P}(\mathrm{t}-3)$ \\
Tihaljina & $\mathrm{Q}(\mathrm{t}-1), \ldots, \mathrm{Q}(\mathrm{t}-10)$ & $\mathrm{P}(\mathrm{t}-1), \ldots, \mathrm{P}(\mathrm{t}-3)$ \\
Klokun & $\mathrm{Q}(\mathrm{t}-1), \ldots, \mathrm{Q}(\mathrm{t}-7)$ & $\mathrm{P}(\mathrm{t}-1), \ldots, \mathrm{P}(\mathrm{t}-3)$
\end{tabular}

\section{Korak - Ocjena kvalitete modela}

Neuralne mreže preslikavaju ulazne vrijednosti u izlazne sa relativno dobrom točnošću ali im to ne osigurava istu kvalitetu ukoliko se mreži predstavi novi neovisni set podataka. Ovaj generalni pristup ispitivanju svojstva dovodi do konačnog prihvaćanja neuronskog modela. U ovakvom slučaju se koriste različite mjere kvalitete pošto ne postoji univerzalna mjera koja će obuhvatiti sve aspekte točnosti. Spomenute mjere MSE i SSE računaju ukupno odstupanje odziva modela u odnosu na mjerene podatke sumirajući pogreške za cijeli skup. Nedostatak ovakvih mjera je slaba procjena točnosti ekstremno visokih i ekstremno niskih vrijednosti. Navedene mjere su često funkcija cilja pa se prema (Dawson i Wilby, 2001) za procjenu modela hidrološkog sustava najčešće koriste: korijen srednje kvadratne pogreške (RMSE), srednja apsolutna pogreška (MAE), srednja kvadratna relativna pogreška (MSRE), koeficijent određenosti $\left(\mathrm{R}^{2}\right)$ i koeficijent učinkovitosti (NS). MSE daje dobru mjeru prilagodbe za visoke protoke, dok je RMSE dobra mjera srednjih protoka. Napominje se da su ove mjere pod velikim utjecajem karakteristika sliva što se mora uzeti u obzirom prilikom usporedbe statističkih pokazatelja na različitim područjima istraživanja. NS i $\mathrm{R}^{2}$ s druge strane daju korisne informacije kod usporedbe između različitih studija jer su neovisne o mjerilu podataka koji se koriste (npr. protok, veličina sliva, vremenska granulacija) pošto su NS i $\mathrm{R}^{2}$ mjere ovisnosti samo modeliranih i mjerenih podataka. Stoga odabrane mjere: MSE, SSE, RMSE, NS i $\mathrm{R}^{2}$ čine široki spektar procjenitelja kvalitete a ujedno omogućuju i usporedbu konceptualnog i parametarskog modela.

\section{Korak-interpretacija rezultata}

Kalibrirani model predstavlja ponašanje hidrološkog sistema pod uvjetima koji su utvrđeni u bazi podataka. Uzimajući ove pretpostavke u obzir, modeliranje kompleksnih krških vodonosnika zahtjeva konceptualni pristup i pristup računalnog učenja. Takovi modeli pokazali su se vrlo efikasni (Kurtulus i Razack, 2006; Fleury et al. 2007; Kong-A-Siou et al. 2011) ali je njihova usporedba i analiza rijeko prezentirana $\mathrm{u}$ istom istraživanju. Metodologija korištena $\mathrm{u}$ disertaciji cilja na specifičnu ideju uporabe vremenskih serija za oblikovanje konceptualnog i neuronskog modela te iskorištavanja njihovih prednosti u simuliranju odnosa padalina i otjecanja 
kao što je prezentirano na Slici 3.26.

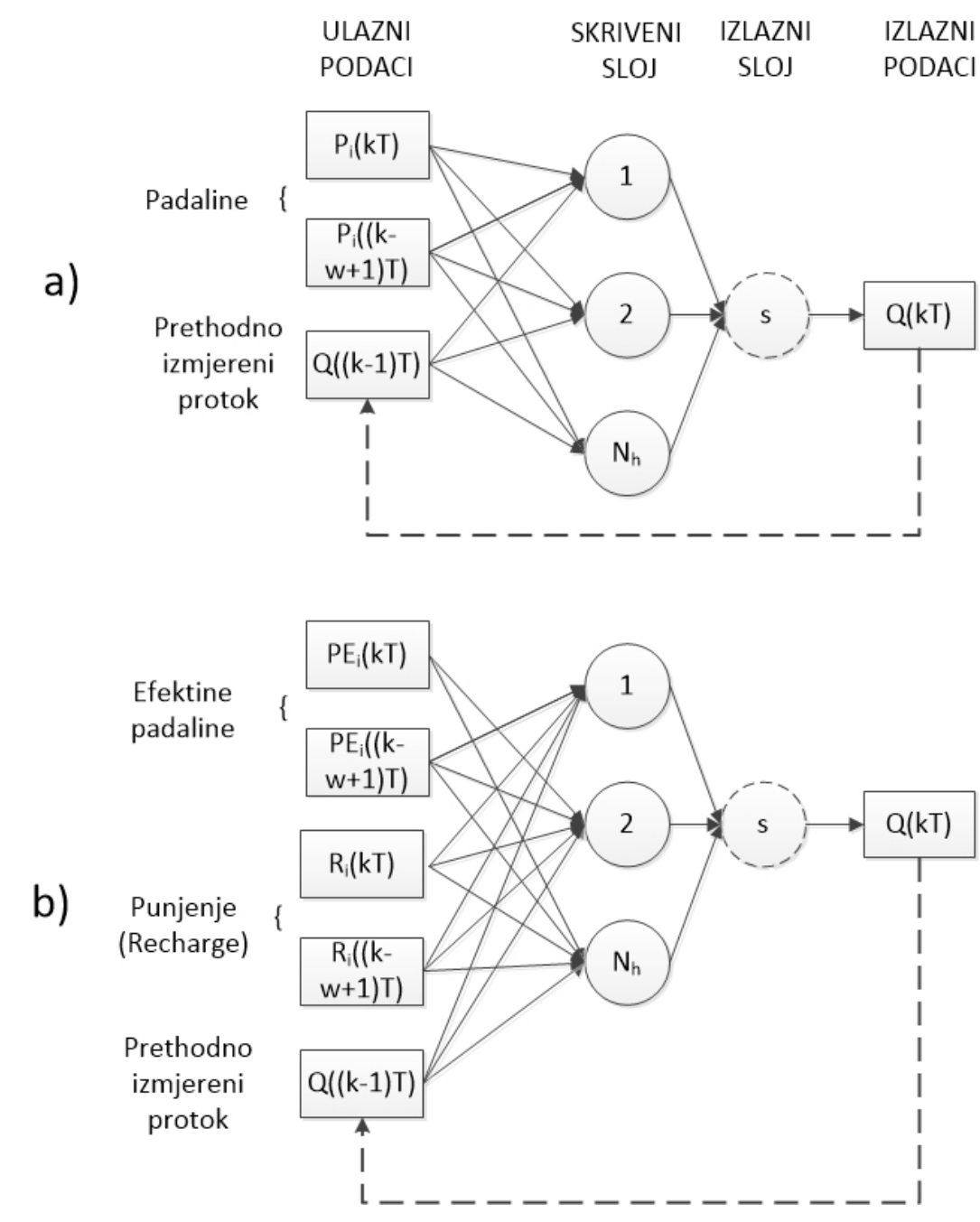

Slika 3.26. Povratni višeslojni perceptron za modeliranje otjecanja: a) arhitektura mreže sa prikupljenim podacima i b) arhitektura mreže sa izlazima konceptualnog modela

Konceptualnim modelom je moguće utvrditi količine efektivne padaline koja direktno otječe te punjenje (eng. recharge) vodonosnika - test će utvrditi kako ovakva modifikacija podataka utječe na konačni rezultat modela. Predloženi modeli simuliraju protok u diskretnom vremenu $k T$ ( $k \in N$, gdje je $T$ duljina promatranog perioda). Sa oznakama $Q(k)$ za protok, $P(k)$ za padaline, $P E(k)$ efektivna padalina, $R(k)$ punjenje te $f_{N N}$ kao nelinearna funkcija implementirana u neuronsku mreži, određen je ulazno-izlazni model kao:

$$
Q(k)=f_{N N}[Q(k-1), P(k), P(k-1), \ldots, P(k-w+1)]
$$

tj.

$$
Q(k)=f_{N N}[Q(k-1), P E(k), P E(k-1), \ldots, P E(k-w+1), R(k), R(k-1), \ldots, R(k-w+1)]
$$

Gdje je $w$ širina pomičnog vremenskog prozora prenesenog iz informaciji o padalinama čija se 
optimalna vrijednost dobiva u koraku 3. kros-korelacijom. Navedeni model je dinamičan, uzimajući u obzir svojstvo ovisnosti o prethodnoj izlaznoj varijabli $Q(k-1)$, koja je ujedno i ulaz u sustav. Generalno je pokazano da u hidrologiji bolju svojstva daju statični modeli koji dobivaju informacije o sustavu prema mjerenim vrijednostima (Artigue et al. 2012). Jednadžba vođena ovom idejom je (prikazana za (3.37) a analogno sa (3.38)):

$$
Q(k)=f_{N N}\left[Q^{p}(k-1), P(k), P(k-1), \ldots, P(k-w+1)\right]
$$

Gdje je $Q^{p}(k-1)$ izmjereni protok u vremenu $k$. Prema (Kong-A-Siou et al. 2011) statični modeli sa prethodno izmjerenim protocima daju odlične rezultate, stoga se statični model koristio u fazi kalibracije a dinamični u fazi simulacije.

\subsubsection{Rezultati}

Za svaku od četiri promatrane stanice tj. izvora formirana je NARX mreža koja je optimirana slijedeći korake sustavnog pristupa. Osnovni "nulti" model formiran je prema VS Opačac zbog činjenice da stanica ima najveći broj dostupnih podataka te se time pretpostavlja da je mreža u mogućnosti prepoznati sezonsku karakteristiku podataka. Postepenim povećavanjem broja čvorova i vremenskih lag-ova u skrivenom sloju dobiveni su rezultati statističkih pokazatelja prikazanih na slikama 3.27.-3.31.

NS

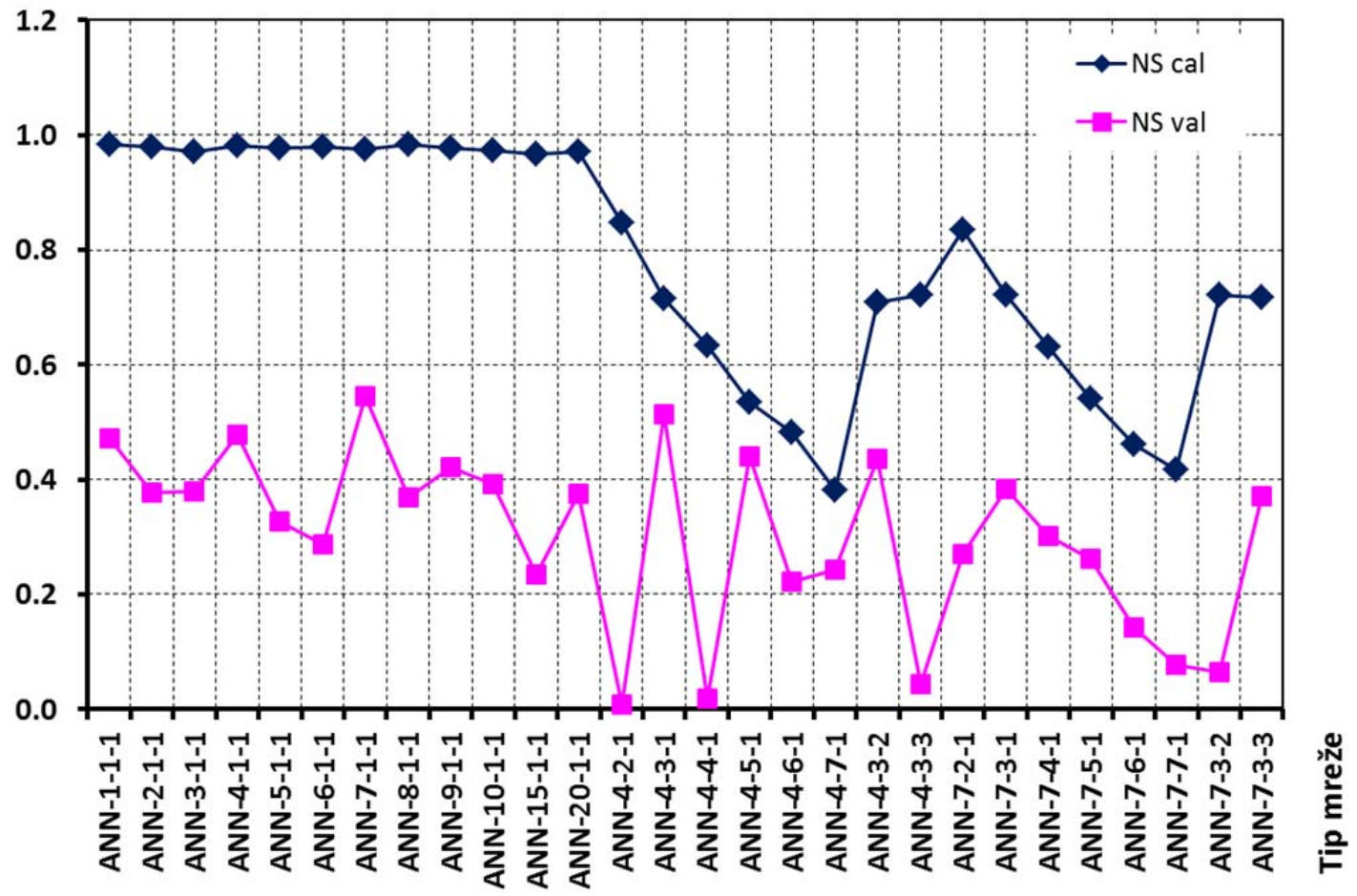

Slika 3.27. Promjena koeficijenta efikasnosti (NS) prema različitim arhitekturama ANN 


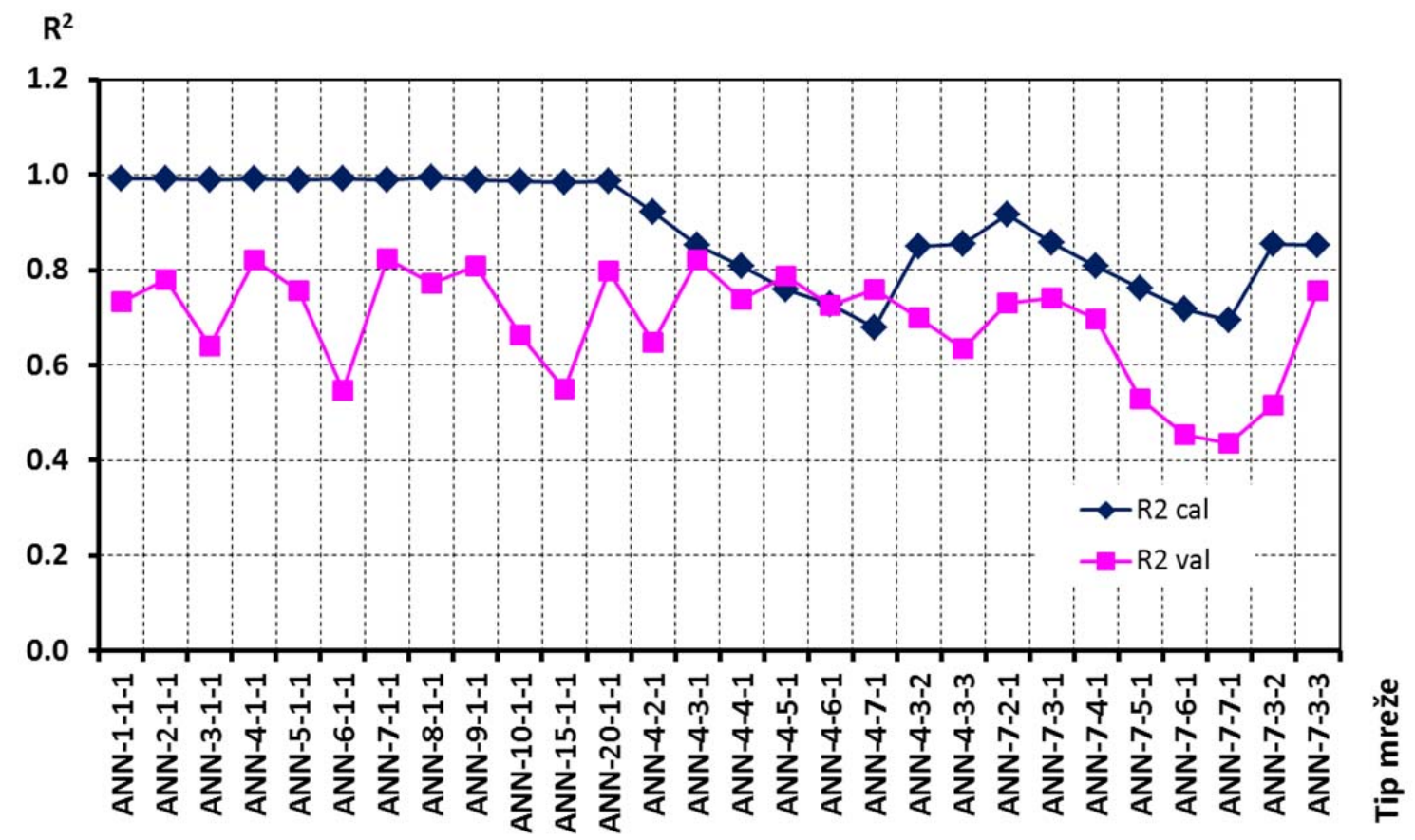

Slika 3.28. Promjena koeficijenta determinacije $\left(R^{2}\right)$ prema različitim arhitekturama ANN

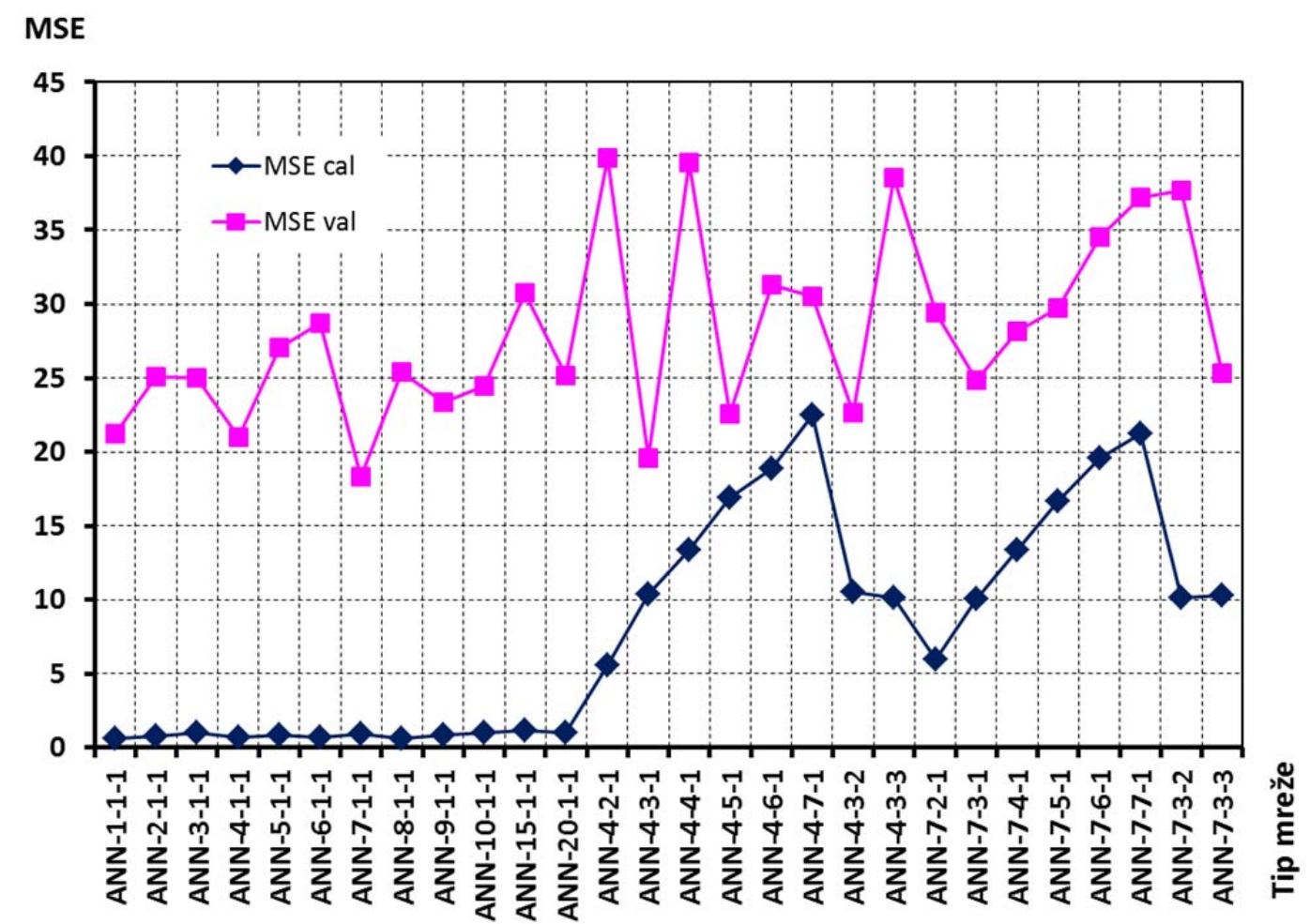

Slika 3.29. Promjena srednje kvadratne pogreške (MSE) prema različitim arhitekturama ANN 


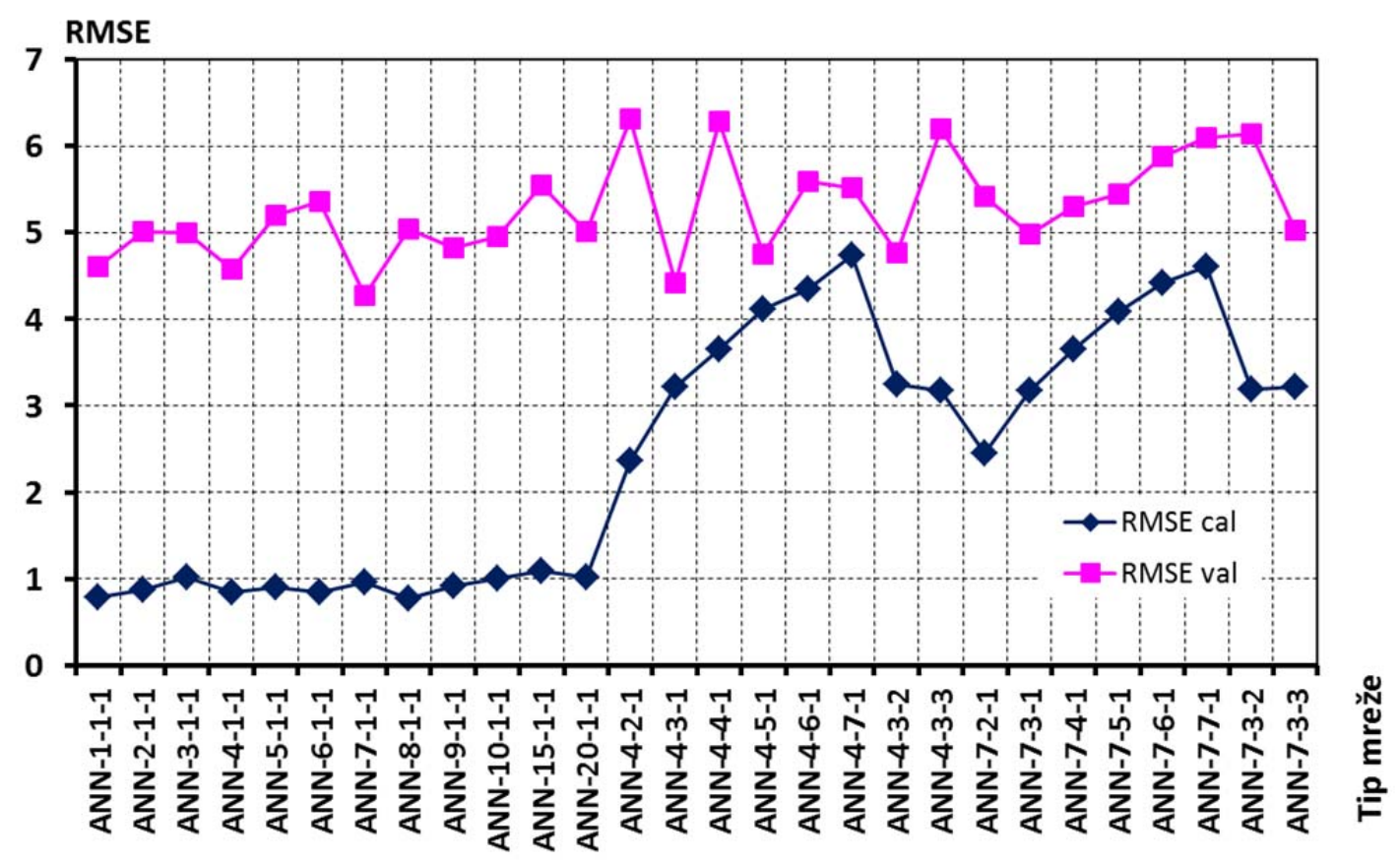

Slika 3.30. Promjena korijena srednje kvadratne pogreške (RMSE) prema različitim arhitekturama ANN

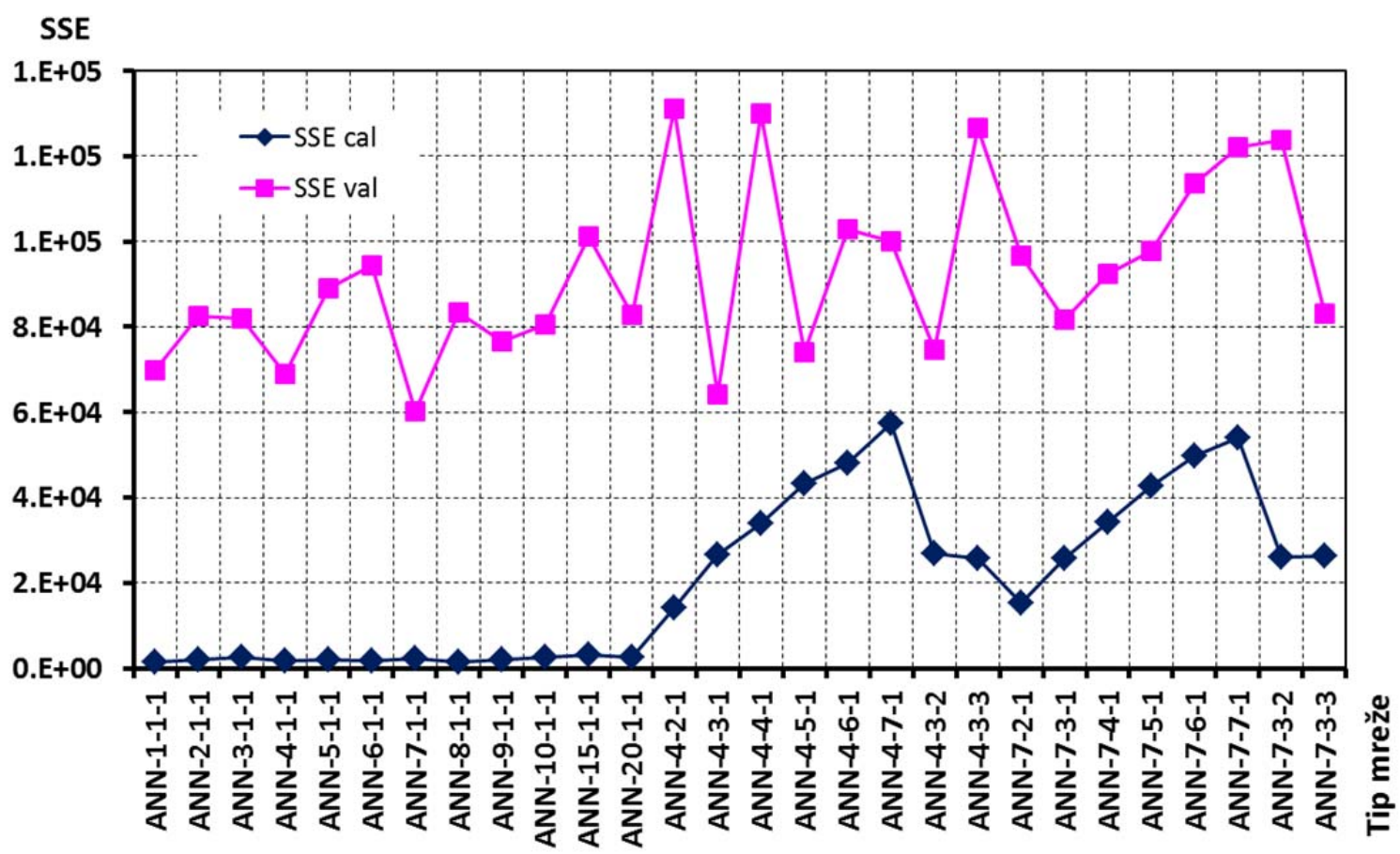

Slika 3.31. Promjena sume kvadratne pogreške (SSE) prema različitim arhitekturama ANN

Oznake ANN-a-b-c predstavljaju redom: a - broj čvorova u skrivenom sloju, b - broj $k$ zaostajanja izlazne serije protoka i c $-k$ zaostajanje vremenske serije padalina. Povećavanje broja čvorova neznatno utječe na kalibracijski set pa su se stoga detaljnije promotrili rezultati simulacijskog seta za kojeg su izdvojene mreže sa 4 i 7 čvorova koje su se pokazale najbolje rezultate prema statističkim pokazateljima. Povećavanjem vremenskog koraka zaostajanja 
točnost mreže postepeno opada, osim za slučaj mreža ANN-4-3-1 i ANN-7-3-1 koje koriste $Q(t$ 3) koraka prilikom simulacije. ANN-4-3-1 i ANN-7-3-1 su se dodatno ispitale sa različitim $P(t$ k) veličinama koji nisu dali značajnije poboljšanje rezultata. Navedeni rezultati pokazuju autokoreliranost protoka ne duži od tri dana i zaostajanje vremenskog koraka padalina za jedan dan što je i uočeno kod CCF funkcije. Uz ovu analizu treba napomenuti da ponovno treniranje mreže sa istim karakteristikama može stvoriti probleme, vidljivo iz Slike 3.32. na kojoj su prikazane dvije mreže iz prvog ispitivanog seta koje su dale najbolje rezultate te je proces treniranja ponovljen 10 puta. Prikazane vrijednosti se odnose na koeficijent NS. Mreža ANN-41-1 nakon sedmog koraka, a ANN-7-1-1 nakon 10. podbacuje sa rezultatima. Iste karakteristike pokazuju i ostali statistički pokazatelji. Razlog ovakvom ponašanju tumači se zaglavljivanjem mreže u lokalnim minimumima zbog načina podijele podataka unutar mreže na setove za treniranje, validaciju i testiranje te inicijalnim težinama i bias-ima koje mreža slučajnim odabirom postavlja na početku treniranja. Preporučljivo je da se svaka nova arhitektura mreže trenira ponovno ukoliko se ovakve greške pojave u prvom treniranju.

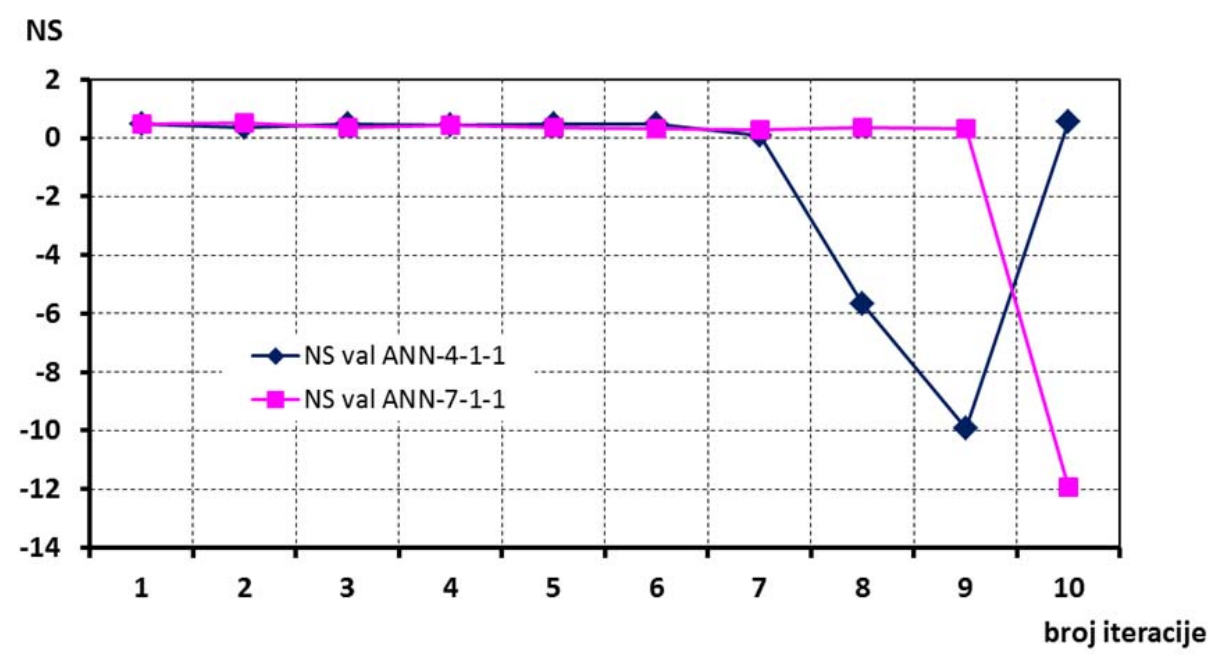

Slika 3.32. Promjena koeficijenta NS u 10 iteracija za mrežu sa 4 i 7 čvorova u skrivenom sloju Rezultati simulacije tj. predviđanje protoka na neovisnom setu bez protoka kao ulaznog povratnog signala su očekivano pokazale lošije rezultate te je primijećeno da su odstupanja NS MSE i SSE slična i nešto manje sa RMSE. $\mathrm{R}^{2}$ odskače od ostalih pokazatelja, zadržava se u vrijednostima od 0.6 do 0.8 osim u slučaju većeg broja $Q(t-k)$ kada su mu vrijednosti ispod 0.6. 


\subsection{Usporedba i implementacija modela}

Ukoliko se usporede simulacije kalibracijskih perioda (prema Tablici 3.16) za odabrane stanice sa rezultatima konceptualnog modela, može se uočiti kvaliteta prilagodbe neuralne mreže (Slika 3.33. - 3.36.) - oblik recesijskih krivulja je generalno dobro opisan, no vršni protoci i dalje ostaju podcijenjeni od strane ANN ali u manjoj mjeri nego kod konceptualnog modela.

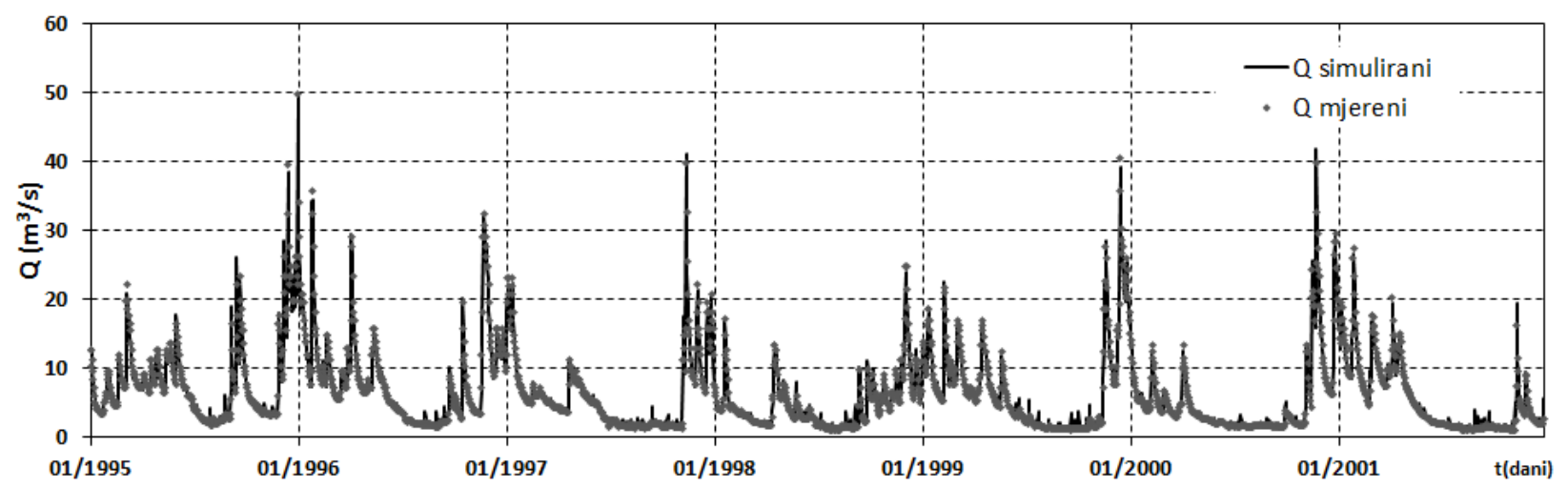

Slika 3.33. Simulirani i izmjereni protok za kalibracijski period (ANN-4-1-1) - izvor Opačac

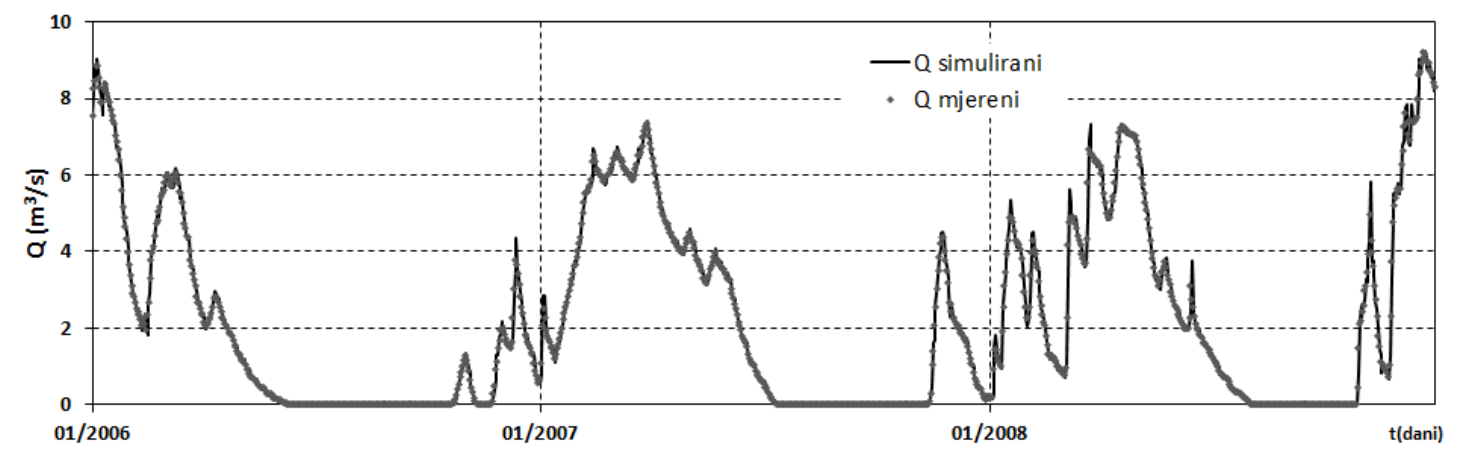

Slika 3.34. Simulirani i izmjereni protok za kalibracijski period (ANN-1-2-2) - izvor Gr. vrelo

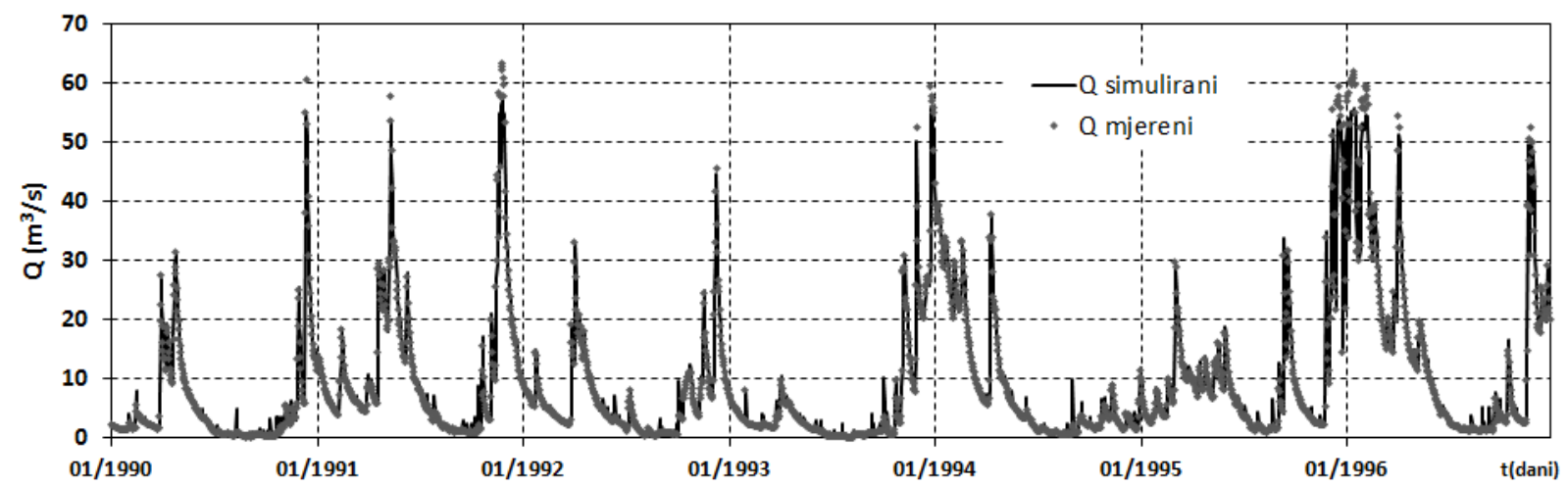

Slika 3.35. Simulirani i izmjereni protok za kalibracijski period (ANN-2-1-1) - izvor Tihaljina 


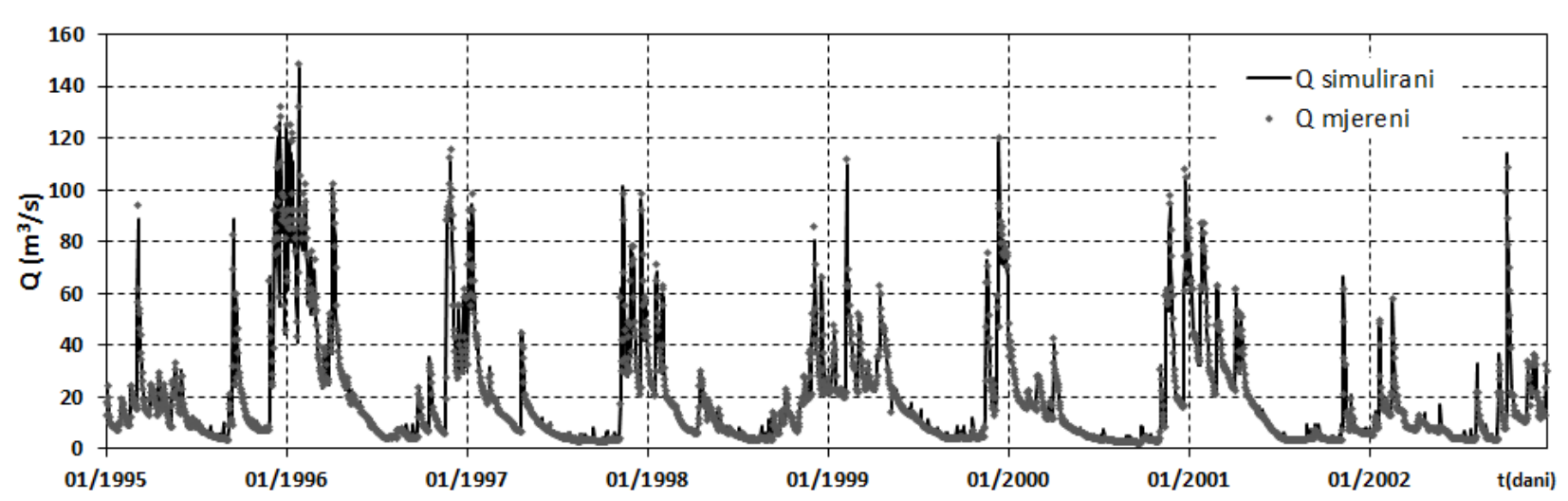

Slika 3.36. Simulirani i izmjereni protok za kalibracijski period (ANN-1-1-1) - izvor Klokun

Rezultati statističkih pokazatelja (Tablica 3.19) mogu to i potvrditi. Iako su u analizu uvrštene relativne (NS i $\mathrm{R}^{2}$ ) i apsolutne (MSE, RMSE, SSE) ocjene pogreške i dalje ostaje pitanje ocjene najboljeg pokazatelja u odnosu na ekstremne vrijednosti pošto se greške najviše stvaraju $u$ periodima intenzivnih oborina.

Tablica 3.19. Usporedba rezultata konceptualnog (CM) i neuralnog (ANN) modela prema statističkim pokazateljima

\begin{tabular}{ccccccccc} 
& \multicolumn{2}{c}{ Opačac } & \multicolumn{2}{c}{ Grudsko vrelo } & \multicolumn{2}{c}{ Tihaljina } & \multicolumn{2}{c}{ Klokun } \\
& CM & ANN & CM & ANN & CM & ANN & CM & ANN \\
\hline NS & 0.826 & 0.982 & 0.858 & 0.982 & 0.858 & 0.996 & 0.828 & 0.990 \\
R $^{2}$ & 0.911 & 0.992 & 0.937 & 0.991 & 0.937 & 0.999 & 0.917 & 0.996 \\
MSE & 4.493 & 0.654 & 2.105 & 0.110 & 2.105 & 0.531 & 307.796 & 5.016 \\
RMSE & 2.645 & 0.809 & 1.223 & 0.331 & 1.223 & 0.729 & 9.567 & 2.240 \\
SSE & 14767 & 1671 & 1536 & 120 & 1536 & 1357 & 224691 & 14652
\end{tabular}

Rezultati predikcije NARX mreža sa zatvorenom petljom za periode kros-validacije prikazani su u Tablici 3.20. Odstupanje mjerenih i simuliranih podaka najveće je kod izvora Grudsko vrelo i Klokun.

Tablica 3.20. Rezultati statističkih pokazatelja za kros-validaciju

\begin{tabular}{ccccc} 
& Opačac & G. vrelo & Tihaljina & Klokun \\
\hline NS & 0.478 & 0.017 & 0.183 & 0.236 \\
$\mathbf{R}^{2}$ & 0.822 & 0.621 & 0.814 & 0.665 \\
MSE & 21.022 & 10.359 & 87.117 & 407.038 \\
RMSE & 4.585 & 3.219 & 9.334 & 20.175 \\
SSE & 69099 & 7562 & 190873 & 297138 \\
\hline Tip mreže & ANN-4-1-1 & ANN-1-2-2 & ANN-2-1-2 & ANN-1-1-1
\end{tabular}


Uzrok lošijim rezultatima predviđanja protoka može se tražiti u malom broju podataka na kojem je izvržena - u oba slučaja su to dvije godine. Za usporedbu, mreža za izvor Opačac korisit $\mathrm{N}=$ 2556 podataka o palim oborinama a izvor Tihaljina $N=2190$. Daljni testovi su izvršeni te su najbolji rezultati prikazani u Tablici 3.21. Prvi stupac "Test-1" se odnosi na simulaciju kada se vrši samo prilagodba podataka a ne predikcija nad kros-validacijskim setom da bi se bolje prikazala razlika rada mreže u odnosu na ostala 3 testa kada se mreža ne uzima u obzir mjerene protoke prilikom predviđanja istih. Test 2 za ulazne podatke uzima dnevne padaline; test 3 ima dodatni input o sezonskoj karakteristici podataka - uz dnevne oborine upisan je i broj mjeseca u kojem je oborina pala kao način uvođenja periodičnosti u sustav. Na kraju su u četvrtom testu dodani i podaci o relativnoj vlažnosti i temperaturama. Zadnji test daje najbolje rezultate, srednje i sumirane greške su smanjene dok relativni pokazatelji ( $\mathrm{R}^{2}$ i NS) imaju manja odstupanja. NS kao jedan od važnijih pokazatelja učinkovitosti modela svojom vrijednošću od 0.58 pokazuje da je prilagodba modela bolja od tzv. "naivne" predikcije $(\mathrm{NS}<0)$ ali i dalje daleko od statistički značajne vrijednosti.

Tablica 3.21. Rezultati različitih testova NARX mreže za izvor Opačac

\begin{tabular}{ccccc} 
& Test 1 & Test 2 & Test 3 & Test 4 \\
\hline NS & 0.982 & 0.144 & 0.528 & 0.582 \\
R $^{2}$ & 0.992 & 0.651 & 0.770 & 0.785 \\
MSE & 0.654 & 34.473 & 19.000 & 16.838 \\
RMSE & 0.809 & 5.871 & 4.359 & 4.103 \\
SSE & 1671 & 113311 & 62454 & 55346
\end{tabular}

Rezultati 4. testa prikazani su na Slici 3.37.

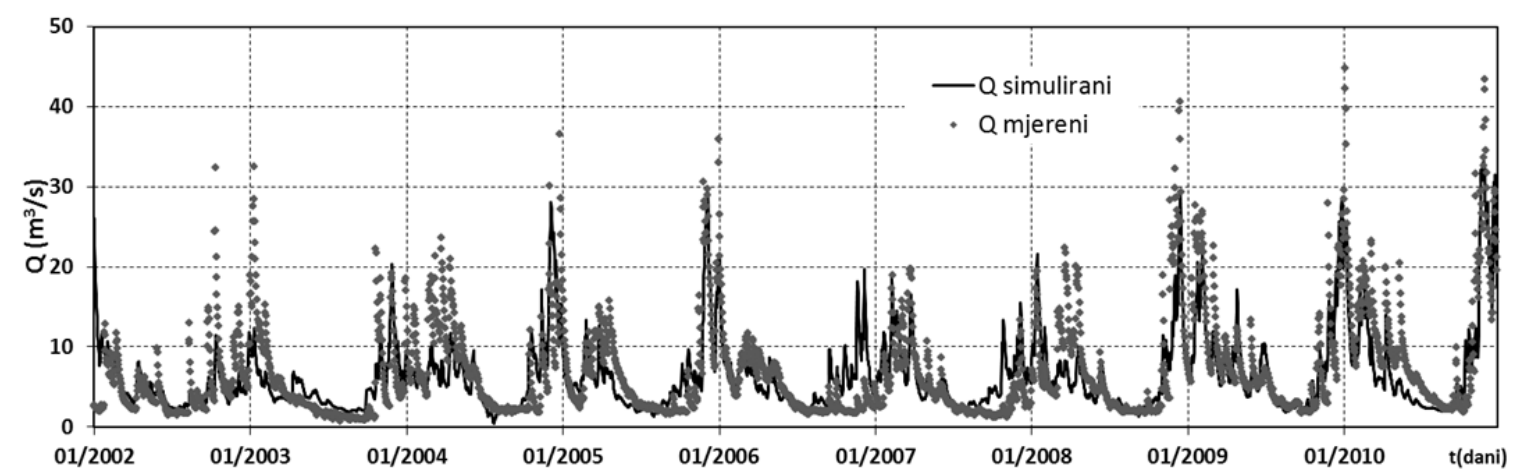

Slika 3.37. Rezultati simulacije na kros-validacijskom setu za Test 4. - izvor Opačac

Mreža 4. testa je dodatno analizirana u odnosu na broj podataka za treniranja, validacije i testiranja te je optimalan omjer 70/15/15. Rezultati su poboljšani korištenjem radijalne bazne funkcije u skrivenom sloju mreže te korištenjem Bayesian regularizacije koja trenira mrežu ažuriranjem težina i bias-a mreže pomoću Levenber-Marquardt optimizacije kombinacijom 
kvadriranih pogrešaka i težina tražeći točnu kombinaciju za najbolju generalizaciju mreže.

Napredak neuronskih mreža u modularnom, cjelovitom i hibridnom modeliranju otvara nove mogućnosti u simulaciji i predviđanju otjecanja. Modularna rješenja koriste klasični "podijeli pa vladaj" princip gdje se glavni problem dijeli u manje podskupine koje je lakše modelirati. Dijeljenje se vrši ili nad podacima (Wu et al. 2010; Zhang i Govindaraju, 2000; Ahmad i Simonovic, 2005) ili nad slivom koji se promatra (Kong-A-Siou et al. 2013). Cjelovito modeliranje (See i Openshaw, 2000) uključuje razvoj različitih modela koji adresiraju neki uobičajeni problem na način da kombinacijom dijelova modela može poboljšati ukupnu učinkovitost u odnosu na pojedinačni model. Hibridni modeli (Rahnama i Barani, 2005; Parkin et al. 2007) su kombinacija dva ili više različitih tipova modela u kojem svaki pod-model ima određenu funkciju. Kombinacija može sadržavati samo neuronske mreže ili su iste izdvojene kao zaseban koncept. Predložena implementacija u ovom radu pripada skupini modularnih modela pošto se određeni procesi opisuju na različite načine, ponajprije definiranje ulaza u neuralnu mrežu pomoću konceptualnog modela. Modularnost se također očituje i u tehnici predprocesiranja ulaznih podataka sa željom da se poboljša točnost predviđanja modela (Wu et al. 2010). Modularni pristup je slijedeći korak u korištenju ANN-ova u hidrologiji u vidu ekspertnog modela koji uključuje prethodna znanja o hidrološkim procesima koja vode ka boljem izboru ulaznih varijabli.

Za odabrane vodomjerne stanice i formirane modele neuralnih mreža utvrđeni su novi ulazni podaci - $P E(k)$ efektivna padalina, $R(k)$ punjenje prema jednadžbi (3.38). Nad novim ulaznim podacima je izvršena transformacija podataka kao što je predloženo u 1. koraku procedure dizajna mreže. Mreža je testirana i na ne transformiranim podacima, pod pretpostavkom da mijenjanje ovakvih podataka može utjecati na sezonske karakteristike ugrađene u podatke te im je također dodana vremenska serija koja označava mjesec u kojem je zabilježena efektivna padalina i punjenje rezervoara. Zbog odabira novih ulaznih varijabli potrebno je ponovno izvršiti sustavni pristup oblikovanja neuralne mreže te su odabrane nove strukture i parametri. Ovaj proces je neizbježan jer uporabom većeg broja ulaznih podataka potrebno je ponovno utvrditi optimalan broj čvorova u skrivenom sloju. Pošto rezultati treniranja mreže i dalje daju dobre rezultate, u Tablicama 3.22. - 3.25. predstavljeni su rezultati iz faze predviđanja protoka. Uz rezultate hibridnog modela, u kurzivu su dodani i rezultati osnovnog parametarskog modela $(\operatorname{NARX}(\mathrm{P}))$. Testovi koji su prezentirani predstavljaju: testiranje sa transformiranim podacima $P E(k)$ i $R(k)$ (Test 5), testiranje sa ne transformiranim podacima $P E(k)$ i $R(k)$ i testiranje sa transformiranim podacima $P E(k), R(k)$ i mjesečnim podacima $m(k), m=1, \ldots, 12$. 
Tablica 3.22. Rezultati hibridnog modela - izvor Opačac

\begin{tabular}{ccccc} 
Opačac & Test 5 & Test 6 & Test 7 & NARX(P) \\
\hline NS & 0.537 & 0.511 & 0.583 & 0.478 \\
$\mathbf{R}^{2}$ & 0.813 & 0.837 & 0.771 & 0.822 \\
MSE & 18.643 & 19.686 & 16.775 & 21.022 \\
RMSE & 4.318 & 4.437 & 4.096 & 4.585 \\
SSE & 61278 & 64709 & 55141 & 69099 \\
\hline Tip mreže & ANN-6-1-1 & ANN-4-1-1 & ANN-4-1-3 & ANN-4-1-1
\end{tabular}

Tablica 3.23. Rezultati hibridnog modela - izvor Grudsko vrelo

\begin{tabular}{ccccc} 
Grudsko vrelo & Test 5 & Test 6 & Test 7 & NARX(P) \\
\hline NS & 0.300 & 0.267 & 0.165 & 0.017 \\
R $^{2}$ & 0.867 & 0.856 & 0.785 & 0.621 \\
MSE & 7.381 & 7.728 & 8.796 & 10.359 \\
RMSE & 2.717 & 2.780 & 2.966 & 3.219 \\
SSE & 5388 & 5641 & 6421 & 7562 \\
\hline Tip mreže & ANN-1-1-1 & ANN-1-1-1 & ANN-3-1-1 & ANN-1-2-2
\end{tabular}

Tablica 3.24. Rezultati hibridnog modela - izvor Tihaljina

\begin{tabular}{ccccc} 
Tihaljina & Test 5 & Test 6 & Test 7 & NARX(P) \\
\hline NS & 0.578 & 0.267 & 0.333 & 0.183 \\
R $^{2}$ & 0.862 & 0.826 & 0.787 & 0.814 \\
MSE & 45.008 & 78.229 & 71.148 & 87.117 \\
RMSE & 6.709 & 8.845 & 8.435 & 9.334 \\
SSE & 98612 & 171401 & 155885 & 190873 \\
\hline Tip mreže & ANN-2-1-1 & ANN-2-2-2 & ANN-2-1-2 & ANN-2-1-1
\end{tabular}

Tablica 3.25. Rezultati hibridnog modela - izvor Klokun

\begin{tabular}{ccccc} 
Klokun & Test 5 & Test 6 & Test 7 & NARX(P) \\
\hline NS & 0.132 & -0.034 & 0.361 & 0.236 \\
R $^{2}$ & 0.584 & 0.576 & 0.615 & 0.665 \\
MSE & 462.104 & 550.973 & 340.293 & 407.038 \\
RMSE & 21.497 & 23.473 & 18.447 & 20.175 \\
SSE & 337336 & 402210 & 248414 & 297138 \\
\hline Tip mreže & ANN-2-2-2 & ANN-1-2-2 & ANN-2-2-2 & ANN-1-1-1
\end{tabular}

Vidljivo je poboljšanje modela i to najviše u testu 7. kada se za ulazne podatke koriste i mjesečni podaci. Ukoliko se uzmu u obzir testiranja sa podacima o oborinama, relativnoj vlažnosti i temperaturi, rezultati pokazuju da korištenje ovakvo transformiranih podataka doprinosi $u$ točnosti predikcije, osim u slučaju kada se koriste ne transformirani podaci. Na slici 3.38 prikazani su odnosi mjerenih i predviđenih otjecanja za najbolje rješenje testova 5-7. Najbolje rješenje prema statistički parametrima zabilježeno je na izvoru Tihaljina (Test 5). Vidljivo je da 
simulirani protoci dobro procjenjuju vrijednosti protoka malih voda $\mathrm{tj}$. $\mathrm{u}$ režimima sporog otjecanja ali nagnutost pravca linearne regresije pokazuje slabe podudarnosti u području visokih protoka.

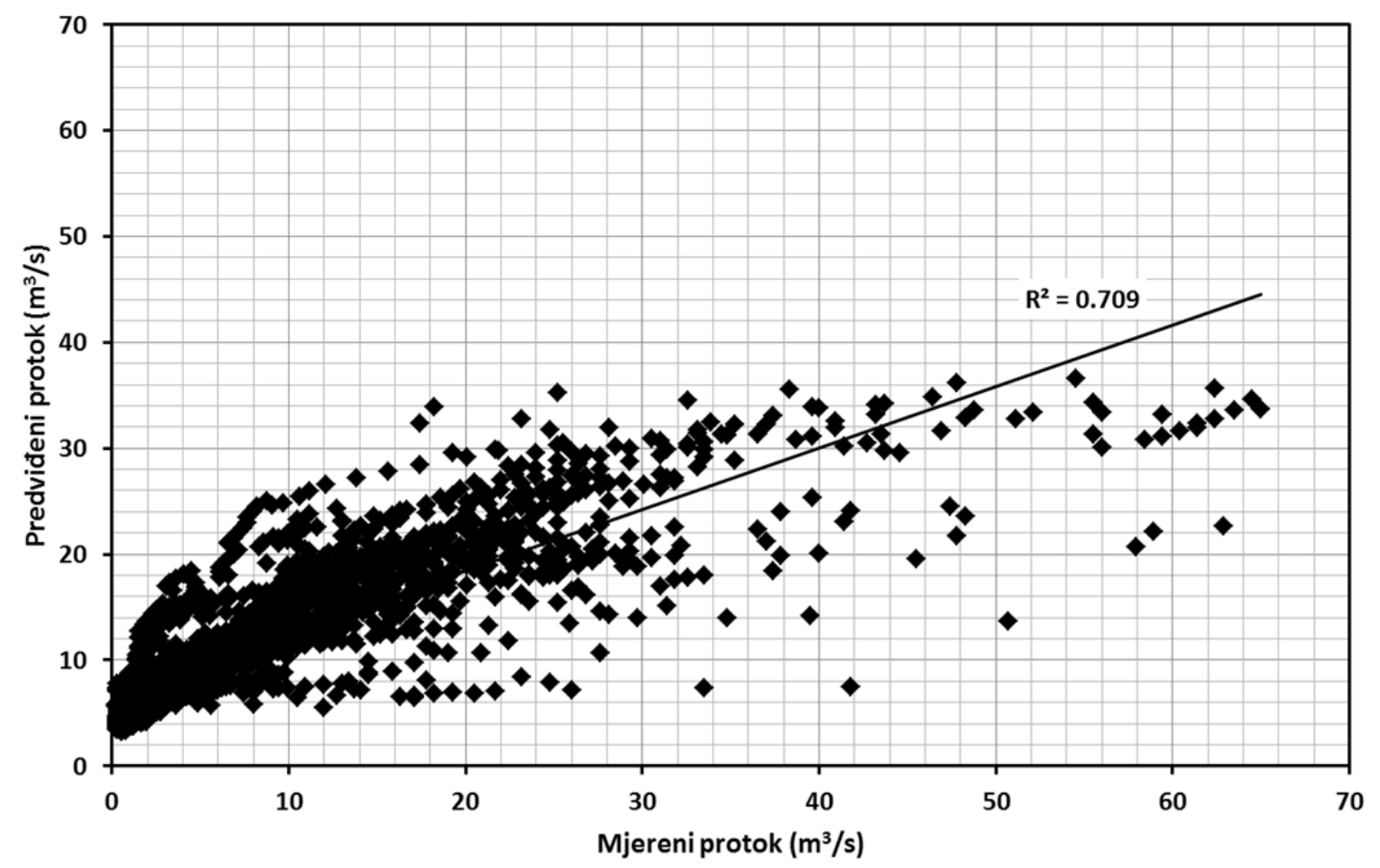

Slika 3.38. Mjereni vs predviđeni protoci za izvor Tihaljina (kros-validacijski period 1.1.1997 -

$$
\text { 31.12.2002) }
$$

\subsection{Rasprava i zaključci}

Da bi se hibridni model neuralne mreže prihvatio kao superiorniji ostaje pitanje identifikacije brzog i sporog otjecanja. Jedini način pronalaženja ovakvih relacija moguće je detaljnom analizom težina koje je NARX mreža odabrala za najbolje rješenje. Rezultate težina je moguće prikazati u raznim softwareskim rješenjima pa tako i u korištenom Matlab-u (verzija R2011b) no dobiveni brojevi nisu jednoznačni kao koeficijent $\theta$ koji je korišten u konceptualnom modelu. Dok $\theta$ radi direktan omjer između brzog i sporog otjecanja, na težine neuralne mreže utječu pragovi mreže (bias) kao i struktura mreže. Većina ispitivanja težina (Wilby et al 2003; Kalteh 2008; Jain i Kumar, 2009,) vrši se na neuralnim mreža sa propagacijom unaprijed (eng. feedforward neural network - FNN) bez povratne veze koju koristi NARX mreža te se prilikom treniranja FNN ciljana funkcija protoka ne koristi kao ulazna serija. Dodatna otegotna okolnost korištenja podataka NARX mreže je i vremenski odmak koji uz sebe ima još jedan prag koji se sumira u ukupnom odzivu. Jain i Kumar (2009) uzimaju u obzir parcijalne izlaze iz mreže (jedan čvor "radi" a ostalima su težine inicirane na nulu prilikom simulacije). Naveden metoda je 
primijenjena na dobivenim rezultatima na sva četiri izvora ali su oni neuvjerljivi. Kalteh (2008) predlaže korištenje alternativne metode $\mathrm{u}$ vidu Garsonovog algoritma koji izračunava relativan doprinos svake od dobivenih težina. Ova se metoda čini prihvatljiva ali također zahtjeva formiranje FNN mreže te se stoga ostavlja kao budući smjer istraživanja parametarskih modela. Moguća je i primjena procijenjenog parametra $\theta$ koji se može iskoristiti na isti način kao i kod konceptualnog modela a to je podjela ukupnog otjecanja u zadanom omjeru. Ovo testiranje potrebno je uzeti sa dozom rezerve jer se na ovaj način direktno utječe na transformaciju funkcije cilja modela a uvode se dodatne pretpostavke koje ne mogu biti direktno potvrđene terenskim ispitivanjima. Iako $\mathrm{u}$ ovom vidu parametarski model nije doprinio novom razumijevanju hidroloških režima otjecanja u kršu, pokazalo se da je korištenje hibridnog modela barem dijelom daje novo fizikalno značenje modelu jer je prepoznata važnost transformiranih ulaznih podataka i time su izvršeno poboljšanje osnovnog modela neuralne mreže. Odabirom strukture mreže koja može vršiti simulaciju protoka bez prezentiranja mjerenih protoka omogućeno je da se ANN pravilno usporedi sa CM modelom. U analiziranim istraživanjima čest je problem donošenja pristranih zaključaka o superiornosti ANN modela nad ostalim na temelju kalibracija koje su izvršene nad ulaznim i izlaznim podacima koje su mreži predstavljene $\mathrm{u}$ isto vrijeme. Ovakve preduhitrene zaključke treba dodatno testirati simulacijskim postupkom jer ukoliko on nije izvršen, rezultati mreže nisu ništa drugo osim aproksimacija funkcije bez temeljnog znanja o strukturi i karakteristikama iste. 


\section{ZAKLJUČCI I SMJER DALJNJEG ZNANSTVENOG DJELOVANJA}

\subsection{Rasprava i zaključci}

$\mathrm{U}$ okviru ovog rada provedena su istraživanja primjene, razvoja i optimiranja konceptualnog i parametarskog modela kojim su se dobila nova saznanja o hidrološkom otjecanju u kršu. Dodani izazov u vidu još ne istraženog područja sa kompleksnim hidrološkim i hidrogeološkim karakteristikama zapravo je bio odlična podloga da se ispitaju određene pretpostavke vezane za tečenje u kršu.

Prva prepreka u kvalitetnoj analizi sistema bili su nedostatak mjerenja vezanih za nivo podzemne vode na promatranom slivu. Uz navedeno, postojeći prikupljeni podaci su oskudni iako se mjerenja na promatranom području vrše od početka 20. stoljeća. Metode analize podataka, koje iako nisu nove u odnosu na mnoga slična istraživanja, postaju imperativ u inicijalnom formiranju strukture modela, neovisno o kakvom tipu modela se radi. Predložene mjere ispitivanja linearne regresije i analize vremenskih serija uspješno su izdvojile varijable koje je moguće predstaviti kao ulazne za tražene funkcije cilja. Predložena metoda kombinacije linearnih regresora i Thiessenovih poligona dala je konačnu potvrdu o važnosti pojedine vodomjerne stanice u odnosu na zabilježene klimatske karakteristike.

Primjena matematičkih modela odnosa padalina i otjecanja može doprinijeti u dobivanju korisnih informacija o vodonosniku u uvjetima kada su terenska ispitivanja ograničenog opsega ili ih nema. Korištenje dva modela, strukturno i tipski različita, pokazala se korisna $\mathrm{u}$ interpretaciji rezultata prilikom njihove implementacije. Konceptualni modularni model 
također zahtjeva određeni tip predobrade podataka ali u hidrološkom smislu. Određivanje koeficijenta krivulje recesije te indeksa baznog toka su postupci koji su vremenski zahtjevni jer su i dalje u mnogim dijelovima bazirani na vizualnoj interpretaciji istraživača kao i prethodnom teoretskom znanju. No, bez ovih podatka konceptualni model sam po sebi bi predstavljao crnu kutiju. Rezultati konceptualnog modela dali su naznake o kakvom tipu i u kakvom omjeru je tečenje na promatranom slivu kroz četiri izvora u kršu. Položaj izvora omogućuje da se promatranjem njihovih režima dobije uvid u rad cijelog sliva jer zbog svojih kapaciteta i položaja vjerojatno pokrivaju većinu pretpostavljene ukupne površine otjecanja. Uočene su određene sličnosti među njima (Tihaljina i Opačac) u zastupljenosti vrste otjecanja kao i količini vode u tlu koju pokazuje SMB pod-model. Zanimljivo je i primijetiti kako oba modela vide razliku u funkcioniranju istočnog dijela Imotskog polja tj. izvora Grudsko vrelo koji pokazuje postojanje samo sporog i može se reći linearnog odgovora na palu kišu. Nizvodni dijelovi sliva (Klokun) pokazuju veći stupanj okršenosti; geološke karte ga naznačavanju kao područje intenzivnih boranja i zasjeka što se kod modela reflektira korištenjem različitih parametara. Konceptualni model je pokazao da je površina sliva varijabilna a njihova prosječna veličina je potvrđena dodatnom analizom linearne regresije odnosa godišnjih padalina i prosječnih protoka. Iako su pretpostavke o veličini sliva značajne u hidrološkom smislu i dalje nije moguće odgovorit na pitanje odnosa autogenog i alogenog sliva tj. način na koji se krški izvori prihranjuju podzemnim provodnicima. Sve dok se terenski temeljno ne ispitaju postojeće podzemne veze u promatranom ali i ostalim krškim vodonosnicima u regiji, ovo pitanje ostaje u domeni spekulacija.

S druge strane, parametarski model neuralnih mreža ne zahtjeva postavljanje određenih fizikalnih pretpostavki da bi se mogao uspješno koristiti kod aproksimacije protoka što definitivno čini njegovu glavnu prednost u usporedbi sa konceptualnim modelom. ANN traži veće razumijevanje same strukture jer se pruža mogućnost odabira različitih vrsta parametara kao što su broj čvorova skrivenog sloja, odabir načina treniranja podataka, odabir transfer funkcije slojeva mreže, omjer podataka za treniranje validaciju i testiranje, vrijeme kašnjenje i mnogi drugi. U takvom okruženju, istraživač se često nalazi u nezavidnoj situaciji - ili može odabrati najjednostavniji mogući model, prilagoditi funkciju cilja i donijeti možda preduhitrene zaključke ili izvršiti treniranje svih mogućih kombinacija što ga dovodi do mnogobrojnih sati simulacija sa neizvjesnim ciljem. Predloženi sustavni pristup uvelike je pomogao izradi ANN modela predstavljenog u ovoj disertaciji te je svakako preporučljiv. NARX mrežu moguće je koristiti na dva načina: kao 
model aproksimacije funkcije - koji vrši u boljoj mjerni nego konceptualni model i kao simulacijski model gdje vrši predviđanje protoka. Predviđanje je očekivano dalo lošije rezultate ali sa naznakama moguće daljnje optimalizacije jer su rezultati izvan područja tzv. naivnog predviđanja te iako statistički pokazatelj efikasnost modela ne prelazi vrijednost 0.6, ostali korišteni pokazatelji daju zadovoljavajuće rezultate. Izvršena implementacija dodatno je poboljšala model i omogućila da se pretpostavka odnosa brzog i sporog otjecanja može detaljnije analizirati u budućim istraživanjima. Na kraju se želi istaknuti da cilj istraživanja nije, niti bi trebao biti, određivanje koji je model bolji, već sinergija znanja koje korištenjem dostupnih modela koji mogu pomoći u boljem razumijevanju kruženja vode u opisanoj specifičnoj geološkoj strukturi.

\subsection{Znanstveni doprinosi i smjer daljnjeg znanstvenog djelovanja}

Očekivani znanstveni doprinos doktorske disertacije može se obrazložiti kroz izvršenu cjelovitu i sustavnu analizu hidroloških i hidrogeoloških svojstava krša na primjeru poniruće prekogranične rijeke (Dalmatinsko zaleđe - Hercegovina). Pripreme podataka je neophodna za matematičke modele koje na osnovi pretpostavljenih veza, bez uvida u unutarnju strukturu sustava, moraju imati što kvalitetnije ulazne podatke. Korišteni sustavni pristup u vidu korištenja statističkih alata omogućio je staranje kvalitetne baze podataka za oba modela. Konceptualni model je uspješno simulirao otjecanje u kršu kroz količine brzog i sporog otjecanja te je prikazan utjecaj parametra krša - koeficijenti recesijske krivulje, indeks sporog tečenja i površina sliva - na rezultate modela. Pomoću parametara krša utvrđene su korelacije od regionalnog značaja na ostalim krškim izvorima na promatranom području primjenom konceptualnog modela. Parametarski model neuronskih mreža u modeliranju otjecanja dao je nova saznanja o utjecaju njegovih karakteristika na točnost i efikasnost modela te je utvrđena potrebna metodologija koja se može primijeniti na promatranom području. Hibridni model je predstavljen sa novim načinom transformacije ulaznih podataka koji je u konačnici poboljšao simulacije ali i predviđanja mjerenih dnevnih protoka.

Daljnji smjer istraživanja modela u vidu poboljšanja vidljiv je za konceptualni model kroz analizu vremenske promjenjivosti slivnog područja koja bi uvelike doprinijela boljem razumijevanju krških vodonosnika. Parametarskom modelu i dalje nedostaju jasni uvidi u fizikalno značenje rezultata te je to jedan od pristupa za daljnja istraživanja. ANN model 
može biti koristan u modeliranju sustava za obranu od poplava ukoliko se koriste satni podaci no nažalost, ovakvi podaci su rijetko dostupni stoga se naglašava važnost uspostave kvalitetne i guste mreže mjernih postaja kao i poboljšanje i bolje održavanje postojeće mreže. Međunarodna suradnja kao i istraživanje integralnim pristupom koji uključuje korištenje postojeći mjernih točaka i prikupljanje podataka sa raznih specifičnih geoloških formacija u kršu omogućilo bi formiranje bolje vodno-gospodarske slike promatranog područja. 


\section{POPIS SLIKA:}

Slika 1.1. Blok dijagram heterogenog krškog akvifera (prema Goldscheider i Drew, 2007)

Slika 1.2. Kretanje vlage na Zemlji

Slika 1.3. Položaj područja istraživanja

Slika 1.4. Osnovna geološka karta sliva

Slika 1.5. Crveno i Modro jezero

Slika 1.6. Slapovi Kravice u zimskom (a) i ljetnom razdoblju (b)

Slika 1.7. Značajnije hidrološke formacije na promatranom području

Slika 1.8. Hidrogeologija Peć Mlini

Slika 1.9. Lokacija razmatranih meteoroloških i vodomjernih stanica u slivu

Slika 2.1. Prikaz stanja raspoloživih podataka na rijeci sa 8 imena. Oznaka $\mathrm{T}$ - temperature; $\mathrm{RH}$ - relativna vlažnost; $\mathrm{P}$ - padaline

Slika 2.2. Smještaj meteoroloških i klimatoloških postaja na slivu

Slika 2.3. Prosječne mjesečne vrijednosti relativne vlažnosti $(\mathrm{RH})$ po mjesecima

Slika 2.4. Konstruirani Thiessenovi poligoni nad slivom. Brojkama su označene VS stanice: 1 Jovica most; 2 - Ričina; 3 - Vrbica; 4 - Proložac; 5 - Šumet; 6 - Opačac; 7 - Kamenmost; 8 Grudsko vrelo; 9 - Peć Mlini niz; 10 - Klobuk; 11 - Humac. Crvene linije predstavljaju KS poligone, plave linije VS poligone a žuta je granica sliva.

Slika 2.5. Odnosi srednjih godišnjih protoka $Q\left(\mathrm{~m}^{3} / \mathrm{s}\right)$ i ukupnih godišnjih padalina $\mathrm{P}(\mathrm{mm})$ za VS Jovića most

Slika 2.6. Odnosi srednjih godišnjih protoka $Q\left(\mathrm{~m}^{3} / \mathrm{s}\right)$ i ukupnih godišnjih padalina $\mathrm{P}(\mathrm{mm}) \mathrm{za}$ VS Ričina 
Slika 2.7. Odnosi srednjih godišnjih protoka $Q\left(\mathrm{~m}^{3} / \mathrm{s}\right)$ i ukupnih godišnjih padalina $\mathrm{P}(\mathrm{mm}) \mathrm{za}$ VS Vrbica

Slika 2.8. Odnosi srednjih godišnjih protoka $Q\left(\mathrm{~m}^{3} / \mathrm{s}\right)$ i ukupnih godišnjih padalina $\mathrm{P}(\mathrm{mm}) \mathrm{za}$ VS Proložac

Slika 2.9. Odnosi srednjih godišnjih protoka $Q\left(\mathrm{~m}^{3} / \mathrm{s}\right)$ i ukupnih godišnjih padalina $P(\mathrm{~mm})$ za VS Šumet

Slika 2.10. Odnosi srednjih godišnjih protoka $Q\left(\mathrm{~m}^{3} / \mathrm{s}\right)$ i ukupnih godišnjih padalina $\mathrm{P}(\mathrm{mm})$ za VS Opačac

Slika 2.11. Odnosi srednjih godišnjih protoka $Q\left(\mathrm{~m}^{3} / \mathrm{s}\right)$ i ukupnih godišnjih padalina $\mathrm{P}(\mathrm{mm}) \mathrm{za}$ VS Kamenmost

Slika 2.12. Odnosi srednjih godišnjih protoka $Q\left(\mathrm{~m}^{3} / \mathrm{s}\right)$ i ukupnih godišnjih padalina $P(\mathrm{~mm})$ za VS Grudsko vrelo

Slika 2.13. Odnosi srednjih godišnjih protoka $Q\left(\mathrm{~m}^{3} / \mathrm{s}\right)$ i ukupnih godišnjih padalina $P(\mathrm{~mm})$ za VS Peć Mlini, nizvodno

Slika 2.14. Odnosi srednjih godišnjih protoka $Q\left(\mathrm{~m}^{3} / \mathrm{s}\right)$ i ukupnih godišnjih padalina $\mathrm{P}(\mathrm{mm}) \mathrm{za}$ VS Klobuk

Slika 2.15. Odnosi srednjih godišnjih protoka $Q\left(\mathrm{~m}^{3} / \mathrm{s}\right)$ i ukupnih godišnjih padalina $\mathrm{P}(\mathrm{mm})$ za VS Humac

Slika 2.16. Autokorelacijske funkcije za vodomjerne stanice VS Jovića most, VS Ričina Ričice, VS Proložac, VS Šumet, VS Kamenmost i VS Peć Mlini,niz

Slika 2.17. Autokorelacijske funkcije za vodomjerne stanice VS Vrbica, VS Opačac, VS Grudsko vrelo, VS Klobuk i VS Humac

Slika 2.18. Kroskorelacijska funkcija za VS: Jovića most, Ričina, Vrbica i Proložac

Slika 2.19. Kroskorelacijska funkcija za VS: Opačac, Kamenmost, Grudsko vrelo, Šumet

Slika 2.20. Kroskorelacijska funkcija za VS: Peć Mlini niz, Klobuk i Humac

Slika 3.1. Konceptualni model 
Slika 3.2. Dijagram toka procjene parametara i procedure transformacije ulaznih podataka. Oznake: $Q i$ - izmjereni protok, $P i$ - padaline, $T i$ - temperature, $R H i$ - relativna vlažnost, $P_{E F F i}$ - efektivne oborine, $A_{E F F i}$ - efektivna površina sliva, $S_{S \max } S_{E \max }$ - maksimalni kapacitet vlage u tlu za pokrov (S) i epikarst (E), $\alpha_{B}-$ koef. recesije sporog otjecanja, $\alpha_{Q}-$ koef. recesije brzog otjecanja, $\theta$ - težinski koeficijent za raspodjelu efektivne oborine, $Q_{Q}-$ komponenta brzog toka, $Q_{B}$ - komponenta sporog toka, $Q_{S I M}$ - ukupni simulirani tok, $R e C h$ - punjenje akvifera and $S_{G W}$ - volumen vode krškog rezervoara. * označava inicijalne vrijednosti

Slika 3.3. Proračun koeficijenta baznog otjecanja za izvor Opačac. Period 1995 - 2010 godina

Slika 3.4. Proračun koeficijenta baznog otjecanja za VS Peć Mlini nizvodno (izvor Tihaljina) Period 1990 - 2002 godina

Slika 3.5. Proračun koeficijenta baznog otjecanja za VS Klobuk nizvodno (izvor Klokun) Period 1990-1991; 1995-2002;2004

Slika 3.6. Proračun koeficijenta baznog otjecanja za VS Grudsko vrelo. Period 1990-1991; 1995-2002;2004

Slika 3.7. Anvelopa krivulje recesije za izvor Grudsko vrelo

Slika 3.8. Anvelopa krivulje recesije za izvor Opačac

Slika 3.9. Anvelopa krivulje recesije za izvor Tihaljina

Slika 3.10. Anvelopa krivulje recesije za izvor Klokun

Slika 3.11. Mjesečne vrijednosti površine sliva za izvor Opačac

Slika 3.12. Simulirani i izmjereni protok za kalibracijski period - izvor Opačac

Slika 3.13. Simulirani i izmjereni protok za validacijski period - izvor Opačac

Slika 3.14. Simulirani i izmjereni protok za kalibracijski period - izvor Grudsko vrelo i zabilježene padaline na MS Imotski

Slika 3.15. Simulirani i izmjereni protok za validacijski period - izvor Grudsko vrelo 
Slika 3.16. Simulirani i izmjereni protok za kalibracijski period - izvor Tihaljina

Slika 3.17. Simulirani i izmjereni protok za kalibracijski period - izvor Tihaljina

Slika 3.18. Simulirani i izmjereni protok za kalibracijski period - izvor Klokun

Slika 3.19. Simulirani i izmjereni protok za validacijski period - izvor Klokun

Slika 3.20. Rezultati primjene modela: a) efektivna oborina; b) ukupni dotok, c) bazna (spora) i d) brza komponenta uskladištenja

Slika 3.21. Osnovna struktura neuralne mreže

Slika 3.22. Funkcioniranje algoritma propagacije greške unatrag

Slika 3.23. Promjena veličine težina: a) promjena smjera i b) brže spuštanje ka minimumu

Slika 3.24. Postupak oblikovanja modela neuralne mreže

Slika 3.25. Arhitektura NARX mreže: a) paralelna i b) serijski paralelna

Slika 3.26. Povratni višeslojni perceptron za modeliranje otjecanja: a) arhitektura mreže sa prikupljenim podacima i b) arhitektura mreže sa izlazima konceptualnog modela

Slika 3.27. Promjena koeficijenta efikasnosti (NS) prema različitim arhitekturama ANN

Slika 3.28. Promjena koeficijenta determinacije $\left(\mathrm{R}^{2}\right)$ prema različitim arhitekturama ANN

Slika 3.29. Promjena srednje kvadratne pogreške (MSE) prema različitim arhitekturama ANN

Slika 3.30. Promjena korijena srednje kvadratne pogreške (RMSE) prema različitim arhitekturama ANN

Slika 3.31. Promjena sume kvadratne pogreške (SSE) prema različitim arhitekturama ANN

Slika 3.32. Promjena koeficijenta NS u 10 iteracija za mrežu sa 4 i 7 čvorova u skrivenom sloju

Slika 3.33. Simulirani i izmjereni protok za kalibracijski period (ANN-4-1-1) - izvor Opačac

Slika 3.34. Simulirani i izmjereni protok za kalibracijski period (ANN-1-2-2) - izvor Gr. vrelo

Slika 3.35. Simulirani i izmjereni protok za kalibracijski period (ANN-2-1-1) - izvor Tihaljina 
Slika 3.36. Simulirani i izmjereni protok za kalibracijski period (ANN-1-1-1) - izvor Klokun

Slika 3.37. Rezultati simulacije na kros-validacijskom setu za Test 4. - izvor Opačac

Slika 3.38. Mjereni vs predviđeni protoci za izvor Tihaljina (kros-validacijski period 1.1.1997 $-31.12 .2002)$ 


\section{POPIS TABELA:}

Tablica 2.1. Ukupna godišnja oborina za razdoblje 1990. - 2014.

Tablica 2.2. Koeficijent korelacije dnevnih količina oborina

Tablica 2.3. Koeficijent korelacije mjesečnih količina oborina

Tablica 2.4. Koeficijent korelacije godišnjih količina oborina

Tablica 2.5. Prikaz srednjih godišnjih temperatura te maksimalnih i minimalnih dnevnih

Tablica 2.6. Koeficijent korelacije srednje godišnje temperature

Tablica 2.7. Karakteristični (prosječni, minimalni i maksimalni) protoci utvrđeni na rijeci sa 8 imena

Tablica 2.8. Rezultati linearne regresije i težinskih koeficijenata Thiessenovih poligona

Tablica 3.1. Ulazni podaci za istraživano područje

Tablica 3.2. Ulazni podaci za istraživano područje

Tablica 3.4. Osnovni parametri recesijske krivulje za izvor Opačac - $Q_{0}$ i $Q_{1}$ označavaju prvu i zadnju vrijednost recesijskog perioda. $\mathrm{Q}_{0}$ i $\mathrm{Q}_{1}$ su vrijednosti dobivene konstrukcijom pravaca $\mathrm{u}$ polu-logaritamskom mjerilu. Simbol a označava vremenski interval između novog inicijalnog protoka, dobivenog ekstrapolacijom. Q' ${ }_{01}$ i Q' ${ }_{02}$ su vrijednosti pomaknute za vremenski interval a u ishodište koordinatnog sistema anvelope.

Tablica 3.5. Osnovni parametri recesijske krivulje za izvor Grudsko vrelo

Tablica 3.6. Osnovni parametri recesijske krivulje za izvor Tihaljina

Tablica 3.7. Osnovni parametri recesijske krivulje za izvor Klokun

Tablica 3.8. Rezultati kalibracije i vrijednosti statističkih parametara za validacijski period izvor Opačac

Tablica 3.9. Rezultati kalibracije i vrijednosti statističkih parametara za validacijski period izvor Grudsko vrelo 
Tablica 3.10. Kalibracijski i validacijski periodi za VS Peć Mlini, nizvodno

Tablica 3.11. Rezultati kalibracije i vrijednosti statističkih parametara za validacijski period izvor Tihaljina

Tablica 3.12. Kalibracijski i validacijski periodi za VS Klokun

Tablica 3.13. Rezultati kalibracije i vrijednosti statističkih parametara za validacijski period izvor Klokun

Tablica 3.14. Karakteristike izvora prema konceptualnom modelu

Tablica 3.15. Prosječne, minimalne i maksimalne količine godišnjeg volumena uskladištene vode za analizirane izvore

Tablica 3.16. Površine slivova promatranih krških izvora prema linearnoj regresiji i konceptualnom modelu

Tablica 3.17. Izbor podataka za kalibraciju modela i neovisni krosvalidacijski period

Tablica 3.18. Članovi ulaznih vektora za 4 krška izvora (4 ANN modela)

Tablica 3.19. Usporedba rezultata konceptualnog (CM) i neuralnog (ANN) modela prema statističkim pokazateljima

Tablica 3.21. Rezultati različitih testova NARX mreže za izvor Opačac

Tablica 3.22. Rezultati hibridnog modela - izvor Opačac

Tablica 3.23. Rezultati hibridnog modela - izvor Grudsko vrelo

Tablica 3.24. Rezultati hibridnog modela - izvor Tihaljina

Tablica 3.25. Rezultati hibridnog modela - izvor Klokun 
Abbott, M.B., Bathurst, J.C., Cunge, J. A., O'Connell, P.E. i Rasmussen, J., (1986) An introduction to the European Hydrological system - Syst?m Hydrologique Europ?en- "SHE". 1:History and philosophy of a physically based distributed modelling system. J. Hydrol, 87: 45-59.

Abrahart, R. J. i See, L. (2000) Comparing neural network and autoregressive moving average techniques for the provision of continuous river flow forecasts in two contrasting catchments. Hydrol. Processes 14, 2157-2172

Abrahart, J. R., Kneale, P. E. i See, L. M. (2005) Neural networks for hydrological modelling. A.A. Balkema Publishers (Leiden, The Netherlands), a member of Taylor \& Francis Group, London, UK

Abrahart, R. J., Anctil, F., Coulibaly, P., Dawson, C. W., Mount, N. J. i See, L. M. (2012) Two decades of anarchy? Emerging themes and outstanding challenges for neural network river forecasting. Progress in Physical Geography, 36, 480-513. doi:10.1177/0309133312444943

Abusaada, M. i Sauter, M. (2013) Studying the flow dynamics of a karst aquifer system with an equivalent porous medium model. Ground Water 51(4): 641-650.

Ahmad, S. i Simonovic, S. P. (2005) An artificial neural network model for generating hydrograph from hydro-meteorological parameters. Journal of Hydrology, 315, 236-251. doi:10.1016/j.jhydrol.2005.03.032

Ahmad, S., Kalra, A. i Stephen, H. (2010) Estimating soil moisture using remote sensing data: A machine learning approach. Advances in Water Resources, 33(1), 69-80. doi:10.1016/j.advwatres.2009.10.008

Ajmera, T. K. i Rastogi, A. K. (2008) Artifical Neural Network application on estimation of Aquifer Transmissivity. Joiurnal of Spatial Hydrology, 8(2).

Akhtar, M. K., Corzo, G. A., van Andel, S. J. i Jonoski, A. (2009) River flow forecasting with artificial neural networks using satellite observed precipitation pre-processed with flow length and travel time information: case study of the Ganges river basin. Hydrol. Earth Syst. Sci. 13, $1607-1618$.

Andrić, I., Bonacci, O., i Jukić, B. (2013) Rezultati najnovijih hidroloških i geomorfoloških istraživanja Crvenog jezera kod Imotskog. Hrvatske vode, 21(86), 344-348.

Artigue, G., Johannet, a., Borrell, V. i Pistre, S. (2012) Flash flood forecasting in poorly gauged basins using neural networks: Case study of the Gardon de Mialet basin (southern France). Nat. Hazards Earth Syst. Sci. 12, 3307-3324.

ASCE (ASCE Task Committee on the Application of Artificial Neural Networks in Hydrology) (2000a) Artificial neural networks in hydrology. I: Preliminary concepts. J. Hydrol. Engng 5, $115-123$.

ASCE (ASCE Task Committee on the Application of Artificial Neural Networks in Hydrology) (2000b) Artificial neural networks in hydrology. II: Hydrologic applications. J. Hydrol. Engng 5, $124-137$. 
Atkinson, T.C. (1977) Diffuse flow and conduit flow in limestone terrain in the Mendip Hills, Somerset (Great Britain) Journal of Hydrology 35: 93-100.

Ay, M. i Kisi, O. (2014) Modelling of chemical oxygen demand by using ANNs, ANFIS and kmeans clustering techniques. Journal of Hydrology, 511, 279-289. doi:10.1016/j.jhydrol.2014.01.054

Aziz, K., Rahman, A., Fang, G., Haddad, K. i Shrestha, S. (2010) Design Flood Estimation for Ungauged Catchments: Application of Artificial Neural Networks for Eastern Australia. World Environmental and Water Resources Congress 2010: pp. 2841-2850.

Bakalowicz, M. (2005) Karst groundwater: a challenge for new resources. Hydrogeol J 13(1):148160

Bazartseren, B., Hildebrandt, G., i Holz, K.-P. (2003) Short-term water level prediction using neural networks and neuro-fuzzy approach. Neurocomputing, 55, 439-450. doi:10.1016/S09252312(03)00388-6

Beach, T., Luzzadder-Beach, S., Dunning, N. i Cook, D. (2008) Human and natural impacts on fluvial karst depressions of the Maya Lowlands. Geomorphology 101: 308-331.

Besaw, L.E., Rizzo, D.M., Bierman, P.R. i Hackett, W.R. (2010) Advances in ungauged streamflow prediction using artificial neural networks Journal of Hydrology, 386 (1-4), pp. 2737.

Birkinshaw, S.J., James, P. i Ewen, J. (2010) Graphical User Interface for Rapid Set-up of SHETRAN Physically-Based River Catchment Model. Environmental Modelling \& Software, 25, 609-610.

Biswas, R. K. (2008) Water Level Prediction By Artificial Neural Network in the SurmaKushiyara River System of Bangladesh. XX, 1-6.

Bögli, A. (1980) Karst Hydrology and Physical Speleology. Springer Verlag, Berlin.

Bojanić, L., Ivičić, D. i Batić V., (1981) Hidrogeologija Imotskog polja s osvrtom na značaj u regionalnom smislu. Geološki Vjesnik 34: 127-135.

Bonacci, O. (1987) Karst hydrology with special references to the Dinaric karst, Springer Verlag, Berlin, Germany.

Bonacci, O. (1993) Karst springs hydrographs as indicators of karst aquifers. Hydrological Sciences Journal, 38(1), 51-62. doi:10.1080/02626669309492639

Bonacci O. (1995) Ground water behaviour in karst: Example of the Ombla Spring (Croatia). Journal of Hydrology 165(1-4): 113-134.

Bonacci, O. (1999) Water circulation in karst and determination of catchment areas: example of the River Zrmanja. Hydrological Sciences Journal 44(3), 373-386.

Bonacci, O. (2001) Monthly and annual effective infiltration coefficients in Dinaric karst: example of the Gradole karst spring catchment. Hydrological Sciences Journal, 46(2), 287-299. doi:10.1080/02626660109492822 
Bonacci, O. i Roje-Bonacci, T. (2000) Interpretation of groundwater level monitoring results in karst aquifers: Examples from the Dinaric karst. Hydrological Processes, 14(14), 2423-2438. doi:10.1002/1099-1085(20001015)14:14<2423::AID-HYP104>3.0.CO;2-2

Bonacci, O. (2004a) Hazards caused by natural and anthropogenic changes of catchment area in karst. Natural Hazards and Earth System Sciences 4(5/6): 655-661.

Bonacci, O. (2004b) Poljes. In: Gunn, J. (Ed.) Encyclopedia of Caves and Karst Science. Fitzroy Dearborn, New York: 599-600.

Bonacci, O., (2006) Crveno i Modro jezero kod Imotskog. Hrvatske Vode 14(54): 45-54. (Croatian)

Bonacci, O. (2007) Analysis of long-term (1878-2004) mean annual discharges of the karst spring Fontaine de Vaucluse (France). Acta Carsologica 36(1), 151-156.

Bonacci. O. i Andrić, I. (2008) Sinking karst rivers hydrology: case of the Lika and Gacka (Croatia). Acta Carsologica 37(2-3), 185-196.

Bonacci, O. i Roje-Bonacci, T. (2008) Water losses from the Ričice reservoir built in the Dinaric karst. Engineering Geology 99(3-4): 121-127.

Bonacci, O. (2010) Analiza nizova srednjih godišnjih temperature zraka u Hrvatskoj. Građevinar 62(9): 781-791. (Croatian)

Bonacci, O., Željković, I. i Galić, A. (2012) Karst rivers’ particularity: an example from Dinaric karst (Croatia/Bosnia and Herzegovina). Environmental Earth Sciences, 70(2), 963-974. doi:10.1007/s12665-012-2187-9

Bonacci, O. i Andrić I. (2015) Karst spring catchment: an example from Dinaric karst. Environmental Earth Sciences. Publicirano online. doi:10.1007/s12665-015-4644-8

Box, G.E.P. i Jenkins, G.M. (1976) "Time series analysis. Forecasting and Cotrol" Holden- day, San Francisco 543p.

Brillinger, D.R. (1975) Time Series Data Analysis and Theory. Holt, Rinehart \& Winston, New York, $500 \mathrm{pp}$.

Brodie, R.S. i Hostetler, S. (2005) A review of techniques for analysing base flow from stream hydrographs, Proceedings of the NZHS-IAH-NZSSS 2005 Conference, 28 November - 2 December, Auckland, New Zealand.

Brušková, V. (2008) Assessment of the base flow in the upper part of Torysa river catchment, Slovak Journal of Civil Engineering, 2008/2, 8 -14.

Boussinesq, J. (1904) Recherches theoretique sur l'ecoulement des nappes d'eau infiltrees dans le sol et sur le debit des sources. J. Math. Pure Appl. 10 (5th Series), 5-78

Bustami, R., Bessaih, N., Bong, C., i Suhaili, S. (2007) Artificial Neural Network for Precipitation and Water Level Predictions of Bedup River. International Journal of Computer Science, 34(November).

Butscher, C. i Huggenberger, P. (2008) Intrinsic vulnerability assessment in karst areas: A numerical modeling approach. Water Resources Research 44, W03408. 
Campolo, M., Adreussi, P. i Soldati, A. (1999) River flood forecasting with a neural network. Water Resour. Res. 35, 1191-1197.

Charlier, J.B., Bertrand, C. i Mudry, J. (2012) Conceptual hydrogeological model of flow and transport of dissolved organic carbon in a small Jura karst system, Journal of Hydrology, 460-461: $52-64$.

Chen C.-S., Chou F.N.-F. i Chen B.P.-T. (2010) Spatial information-based back-propagation neural network modeling for outflow estimation of ungauged catchment. Water Resources Management 24: 4175-4197.

Chen, Y. H. i Chang, F. J. (2009) Evolutionary artificial neural networks for hydrological systems forecasting. Journal of Hydrology, 367(1-2), 125-137. doi:10.1016/j.jhydrol.2009.01.009

Chitsazan, M., Rahmani, G. i Neyamadpour, A. (2013) Groundwater level simulation using artificial neural network: a case study from Aghili plain, urban area of Gotvand, south-west Iran. Geopersia, 3(1), 35-46.

Chung, C. H., Chiang, Y. M. i Chang, E. J. (2012) A spatial neural fuzzy network for estimating pan evaporation at ungauged sites. Hydrology and Earth System Sciences, 16, 255-266. doi:10.5194/hess-16-255-2012

Čalić, J. (2011) Karstic uvala revisited: Toward a redefinition of the term. Geomorphology 134(12): $32-42$

Daliakopoulos, I. N., Coulibaly, P., i Tsanis, I. K. (2005) Groundwater level forecasting using artificial neural networks. Journal of Hydrology, 309, 229-240. doi:10.1016/j.jhydrol.2004.12.001

Dastorani, M.T., Moghadamnia, A., Piri, J., i Rico-Ramirez, M. (2010) Application of ANN and ANFIS models for reconstructing missing flow data. Environmental Monitoring and Assessment 166: $421-434$

Dawson, C.W. i Wilby, R.L. (2001) Hydrological modelling using artificial neural networks. Progress in Physical Geography 25: 80-108.

Dawson, C. W., Harpham, C., Wilby, R. L. i Chen, Y. (2002) Evaluation of artificial neural network techniques for flow forecasting in the River Yangtze, China. Hydrol. Earth Syst. Sci. 6, 619-626.

Dawson, C. W., Abrahart, R. J., Shamseldin, A. Y. i Wilby, R. L. (2006) Flood estimation at ungauged sites using artificial neural networks. Journal of Hydrology, 319, pp.391-409.

Demuth, H.B. i Beale, M.H. (2004) Neural Network Toolbox ${ }^{\mathrm{TM}}$ User's Guide, The MathWorks, Inc

Denić-Jukić, V. i Jukić, D. (2003) Composite transfer functions for karst aquifers. J. Hydrol. 274, 80-94.

Deswal, S. i Pal, M. (2008) Artificial Neural Network based Modeling of Evaporation Losses in Reservoirs, 228-232.

Diaconescu, E. (2008) The use of NARX neural networks to predict chaotic time series. WSEAS Transactions on Computer Research, 3(3), 182-191. 
Diamantopoulou, M., Antonopoulos, V. Z. i Papamichail, D. M. (2005) The Use of a Neural Network Technique for Predicition of Water Quality Parameters of Axios River in Northen Greece. European Water 11/12, 55-62.

Dooge, J.C.I. (1973) The linear theory of the unit hydrologic systems. Tech. Bull. U.S. Dep. Agric., No. 1468, U.S. Gov. Print. Off., Washington, D.C.

Eagleman, J.R. (1967) Pan evaporation, potential and actual evapotranspiration. J Appl Meteorol $6: 482-488$

Eckhardt, K. (2005) How to construct recursive digital filters for base flow separation. Hydrological Processes 19: 507-515.

Eisenlohr, L., Bouzelboudjen, M., Kiraly, L., i Rossier, Y. (1997a), Numerical versus statistical modeling of natural response of a karst hydro- geological system, J. Hydrol., 202, 244-262.

Eisenlohr, L., Kiraly, L., Bouzelboudjen, M.i Y. Rossier (1997b), A numerical simulation as a tool for checking the interpretation of karst springs hydrographs, J. Hydrol., 193, 306-315.

Fleury, P., Plagnes, V. i Bakalowicz, M. (2007) Modelling of the functioning of karst aquifers with a reservoir model: application to Fontaine de Vaucluse (south of France). J. Hydrol. 345, 38-49.

Elshorbagy, A., Simonovic, S. P. i Panu, U. S. (2002) Noise reduction in chaotic hydrologic time series: Facts and doubts. Journal of Hydrology, 256, 147-165. doi:10.1016/S0022-1694(01)005340

Ford, D.C. i Williams, P.W. (1989) Karst geomorphology and hydrology. Unwin Hyman, London.

Ford, D. i Williams, P. (2007) Karst Hydrogeology and Geomorphology. John Wiley and Sons, Chichester.

Gabrovsek, F. i Dreybrodt, W. (2001) A model of the early evolution of karst aquifers in limestone in the dimensions of length and depth. Journal of Hydrology. 240(3-4): 206-224.

Gadgay, B., Kulkarni, S. i Chandrasekhar, B. (2012) Novel Ensemble Neural Network Models for better Prediction using Variable Input Approach. International Journal of Computer Applications, 39(18), 37-45. doi:10.5120/5082-7268

Garašić, M. (2001) New speleohydrogeological research of Crveno Jezero (Red Lake) near Imotski in Dinaric karst area (Croatia, Europe): International speleodiving expedition 'Crveno jezero 98'. 13th International Congress of Speleology, Speleo Brazil 2001.

Garcia, L. A. i Shigidi, A. (2006) Using neural networks for parameter estimation in ground water. Journal of Hydrology, 318, 215-231. doi:10.1016/j.jhydrol.2005.05.028

Ghumman, A. R., Ghazaw, Y. M., Sohail, A. R., i Watanabe, K. (2011. Runoff forecasting by artificial neural network and conventional model. Alexandria Engineering Journal, 50(4), 345350. doi:10.1016/j.aej.2012.01.005

Gibbs, M. S., Morgan, N., Maier, H. R., Dandy, G. C., Holmes, M. i Nixon, J. B. (1999) Use of Artificial Neural Networks for Modelling Chlorine Residuals in Water Distribution Systems.

Girija, T. R., Mahanta, C. i Chandramouli, V. (2007) Water quality assessment of an untreated effluent impacted urban stream: The Bharalu tributary of the Brahmaputra River, India. Environmental Monitoring and Assessment, 130, 221-236. doi:10.1007/s 10661-006-9391-6 
Goepert, N., Goldscheider, N. i Scholz, H. (2011) Karst geomorphology of carbonatic conglomerates in the Folded Molasse zone of the Northern Alps (Austria/Germany). Geomorphology 130(3-4): 289-298.

Goldscheider, N. (2005) Fold structure and underground drainage pattern in the alpine karst system Hochifen-Gottesacker. Ecologae Geologicae Helvetiae 98: 1-17.

Goldscheider, N., Drew, D. i Worthington, S. (2007) Introduction. In: Goldscheider N, Drew D (eds), Methods in karst hydrogeology.

Govindaraju, R.S. i Ruo, A.R. (2000), Artificial Neural Networks in Hydrology, Kluwer Academic Publishers, Dordrecht.

Gunn, J. (1986) A conceptual model for conduit flow dominated karst aquifers. In: Günay, G., Johnson, A.I. (Eds.), Proc. Ankara Symp. “Karst water resources”, July 1985, IAHS Publ. no. 161, pp. 587-596.

Halihan, T. i Wicks, C.M. (1998) Modeling of storm responses in conduit flow aquifers with reservoirs. J. Hydrol. 208, 82-91.

Haghizadeh, A. i Goudarzi, E. (2010) Estimation of Yield Sediment Using Artificial Neural Network at Basin Scale. Australian Journal of Basic and Applied Sciences, 4(7), 1668-1675.

Hannan, E.J. (1970) Multiple time series. Wiley, New York, 536 pp.

Hartmann, A., Kralik, M., Humer, F., Lange, J. i Weiler, M., (2012) Identification of a karst system's intrinsic hydrodynamic parameters: upscaling from single springs to the whole aquifer. Environ. Earth Sci. 65, 2377-2389.

Hartmann, A., Barberá J.A., Lange, J., Andreo, B., i Weiler, M. (2013a) Progress in the hydrologic simulation of time variant recharge areas of karst systems - exemplified at a karst spring in Southern Spain. Advances in Water Resources 54: 149-160.

Hartmann, A., Wagener, T., Rimmer, A., Lange, J., Brielmann, H. i Weiler, M. (2013b) Testing the realism of model structures to identify karst system processes using water quality and quantity signatures. Water Resources Research 49: 3345-3358.

Hartmann, A., Goldscheider, N., Wagener, T., Lange, J. i Weiler, M. (2014) Karst water resources in a changing world: Review of hydrological modeling approaches. Reviews of Geophysics, 52(April). doi:10.1002/2013RG000443

Heng, S., \& Suetsugi, T. (2013) Using Artificial Neural Network to Estimate Sediment Load in Ungauged Catchments of the Tonle Sap River Basin, Cambodia. Journal of Water Resource and Protection, 2013(February), 111-123.

Herak, M. (1986) A new concept of geotectonics of the dinarides. Acta Geologica 16: 1-42.

Hisdal, H., Tallaksen, L.M., Clausen, B., Peters, E. i Gustard, A. (2004) Hydrological Drought Characteristics. In: Tallaksen, L. M. \& Lanen, H. A. J. van (2004) (Eds) Hydrological Drought Processes and Estimation Methods for Stream flow and Groundwater. Developments in Water Sciences 48, Elsevier Science BV, The Netherlands, 139-198.

Honaker, J. i King, G. (2010) What to do About Missing Values in Time Series Cross-Section Data. Am. J. Pol. Sci. 54, 561-581. 
Hong, Y., Hsu, K.-L., Sorooshian, S. i Gao, X. (2004) Precipitation Estimation from Remotely Sensed Imagery Using an Artificial Neural Network Cloud Classification System. Journal of Applied Meteorology, 43, 1834-1853. doi:10.1175/JAM2173.1

Horton, R.E. (1933) The role of infiltration in the hydrological cycle. Trans. Am. Geophys. Union, $14,446-460$.

Hsu, J.-L., Gupta, H. V. i Sorooshian, S. (1995) Artificial neural network modelling of the rainfall-runoff process. Water Resour. Res. 31, 2517-2530.

Hu, T. S., Lam, K. C. i Ng, S. T. (2001) River flow time series prediction with a range-dependent neural network. Hydrol. Sci. J. 46, 729-745.

Hu, C., Hao, Y., Yeh, T.-C. J., Pang, B.i Wu, Z. (2008) Simulation of spring flows from a karst aquifer with an artificial neural network. Hydrological Processes 22: 596-604.

Jain, A., Sudheer, K.P. i Srinivasulu S. (2004) Identification of physical processes inherent in artificial neural network rainfall runoff models, Hydrol. Process., 18(3), 571-581, doi:10.1002/hyp.5502.

Jain, A. i Srinivasulu, S. (2006) Integrated approach to model decomposed flow hydrograph using artificial neural network and conceptual techniques. Journal of Hydrology, 317, 291-306. doi:10.1016/j.jhydrol.2005.05.022

Jain, A. i Kumar, S. (2009) Dissection of trained neural network hydrologic models for knowledge extraction. Water Resources Research, 45(May 2008), 1-17. doi:10.1029/2008WR007194

Jakeman, A. J. i Hornberger, G.M. (1993) How much complexity is warranted in a rainfall-runoff model? Water Resources Research 29: 2637-2649.

Jenkins, G.M. i Watts, D.G. (1968) Spectral analysis and its applications. Holden Day, San Francisco, CA 525 pp.

Jha, G. K. (2007) Artificial neural networks and its applications.

http://www.iasri.res.in/ebook/EBADAT/5-Modeling\%20and\%20Forecasting\%20Techniques $\%$ 20Agriculture/5-ANN_GKJHA_2007.pdf

Johannet, A., Mangin, A. i D'Hulst, D. (1994), Subterranean water infiltration modelling by neural networks: use of water source flow, in ICANN ' 94 - Proceedings of the International Conference on artificial neural networks, Sorrento, Italy, 26-29 May 1994, pp.1033-1036, Spring-Verlag, London

Johannet A., Vayssade B. i Bertin D. (2008) Neural networks: from black box towards transparent box application to evapotranspiration modeling International Journal of Computational Intelligence, 4 (3)

Jukić, D. i Denić-Jukić, V. (2004) A frequency domain approach to groundwater recharge estimation in karst. Journal of Hydrology, 289(1-4), 95-110. doi:10.1016/j.jhydrol.2003.11.005

Jukić, D. i Denić-Jukić, V. (2006) Nonlinear kernel functions for karst aquifers. J Hydrol 328: 360374.

Jukic, D. i Denic-Jukic, V. (2008) Estimating parameters of groundwater recharge model in frequency domain: Karst springs Jadro and Žrnovnica. Hydrological Processes 22: 4532- 4542. 
Jukić, D. i Denić-Jukić, V. (2009) Groundwater balance estimation in karst by using a conceptual rainfall-runoff model, Journal of Hydrology, 373(2009): 302-315.

Kalteh, A.M. (2008) Neural Rainfall-runoff modelling using artificial (ANNs): modelling and understanding. Caspian Journal of Environmental Sciences, 6(1), 53-58.

Kanaet, T. (1958) Hidrografske prilike u slivu Tihaljina - Mlade - Trebižat, Zbornik radova V kongresa geografa Jugoslavije

Kaufmann, G. i Braun, J. (2000) Karst Aquifer evolution in fractured, porous rocks. Water Resour. Res. 36(6): 1381-1391.

Kaufmann, G. (2009) Modelling karst geomorphology on different time scales. Geomorphology 106: 62-77.

Kim, J. W. i Pachepsky, Y. a. (2010) Reconstructing missing daily precipitation data using regression trees and artificial neural networks for SWAT streamflow simulation. Journal of Hydrology, 394(3-4), 305-314. doi:10.1016/j.jhydrol.2010.09.005

Kiraly, L. i Morel, G. (1976) Etude de regularisation del'Areuse par modèle mathématique. Bulletin du Centre d'Hydrogéologie, Neuchatel 1: 19-36.

Kiraly, L., Perrochet, P., i Rossier, Y. (1995) Effects of the epikarst on the hydrograph of karst springs: a numerical approach. Bulletin d'Hydrogeologie 14: 199 - 200.

Klemeš, V. (1986) Operational testing of hydrological simulation models, Hydrol. Sci. J., 31(1), $13-24$.

Kong-A-Siou, L., Johannet, A., Borrell, V. i Pistre, S. (2011) Complexity selection of a neural network model for karst flood forecasting: The case of the Lez Basin (southern France). Journal of Hydrology, 403, 367-380. doi:10.1016/j.jhydrol.2011.04.015

Kong-A-Siou, L., Johannet A., Borrell V. i Pistre S. (2012) Optimization of the generalization capability for rainfall-runoff modeling by neural networks: the case of the Lez aquifer (southern France) Environ. Earth Sci., 65 (8), pp. 2365-2375

Kong-A-Siou, L., Cros, K., Johannet, A., Borrell-Estupina, V. i Pistre, S. (2013) Knox Method, Or Knowledge Extraction From Neural Network Model. Case Study On The Lez Karst Aquifer. Journal of Hydrology, 507, 19-32. doi:doi:10.1016/j.jhydrol.2013.10.011

Kordilla, J., Sauter, M., Reimann, T. i Geyer, T. (2012) Simulation of saturated and unsaturated flow in karst systems at catchment scale using a double continuum approach. Hydrology and Earth System Sciences 16(10): 3909-3923.

Kovacs, A., i Sauter, M. (2007) Modelling karst hydrodynamics. Methods in karst hydrogeology, edited by N. Goldscheider and D. Drew. Taylor and Francis/Balkema, London, UK. pp. 65-91.

Kraller, G., Warscher, M., Kunstmann, H., Vogl, S., Marke, T. i Strasser, U. (2012) Water balance estimation in high Alpine terrain by combining distributed modeling and a neural network approach (Berchtesgaden Alps, Germany). Hydrology and Earth System Sciences, 16, 1969-1990. doi:10.5194/hess-16-1969-2012

Kresic, N. i Stevanovic, Z. (2010) Groundwater hydrology of springs: engineering, theory, management, and sustainability. Butterworth-Heinemann, Elsevier, Jordan Hill, Oxford, pp 312316 
Kuhta, M., Brkić, Ž. i Stroj, A. (2012) Hydrodynamic characteristics of Mt. Biokovo foothill springs in Croatia. Geologia Croatica, 65(1), 41-51. doi:10.4154/gc.2012.03

Kumar, D. N., Raju, K. S. i Sathish, T. (2004) River Flow Forecasting using Recurrent Neural Networks. 143-161.

Kurtulus, B. i Razack, M. (2006) Evaluation of the ability of an artificial neural network model to simulate the input output responses of a large karstic aquifer: the La Rochefoucauld aquifer (Charente, France). Hydrogeol J 15:241-254.

Labat, D., Ababou, R., i Mangin, A. (2000) Rainfall-runoff relations for karstic springs. Part I: Convolution and spectral analyses. Journal of Hydrology, 238(3-4), 123-148. doi:10.1016/S00221694(00)00321-8

Lallahem, S. i Mania, J. (2003) A nonlinear rainfall-runoff model using neural network technique: example in fractured porous media. Mathematical and Computer Modelling, 37(03), 1047-1061. doi:10.1016/S0895-7177(03)00117-1

Larocque, M., Mangin, A., Razack, M. i Banton, O. (1998) Contribution of correlation and spectral analyases to the regional study of a large karst aquifer (Charente, France). Journal of Hydrology, 205, 217-231.

Le Moine, N., Andréassian, V., Perrin, C. i Michel, C. (2007) How can rainfall-runoff models handle intercatchment groundwater flows? Theoretical study based on 1040 French catchments. Water Resources Research, 43, 1-11. doi:10.1029/2006WR005608

Le Moine, N., Andreassen, V. i Mathevet, T. (2008) Confronting surface- and groundwater balances on the La Rochefoucauld-Touvre karstic system (Charente, France). Water Resources Research 44, W03403. doi: 10.1029/2007WR005984.

Liedl, R., Sauter, M., Hückenhaus, D., Clemens, T., i Teutsch G. (2003) Simulation of the development of karst aquifers using a coupled continuum pipe flow model. Water Resources Research, 39(3): 1057pp.

Loaiciga, H.A., Maidment, D.R. i Valdes, J.B. (2000) Climate-change impacts in a regional karst aquifer, Texas, USA. Journal of Hydrology 227(1-4): 173-194.

Lohani, A. K., Kumar, R. i Singh, R. D. (2012) Hydrological time series modeling: A comparison between adaptive neuro-fuzzy, neural network and autoregressive techniques. J. Hydrol. 442-443, 23-35.

Maillet, E. (1905) Essais d'Hydraulique Souterraine et Fluviale. Hermann, Paris

Maiti, S. i Tiwari, R. K. (2013) A comparative study of artificial neural networks, Bayesian neural networks and adaptive neuro-fuzzy inference system in groundwater level prediction. Environmental Earth Sciences, 71, 3147-3160. doi:10.1007/s12665-013-2702-7

Mangin, A. (1984) Pour une meilleure connaissance des systemes hydrologiques a partir des analyses correlatoire et spectrale. Journal of Hydrology 67, 25-43.

Malík, P. i Vojtková, S. (2012) Use of recession-curve analysis for estimation of karstification degree and its application in assessing overflow/underflow conditions in closely spaced karstic springs. Environmental Earth Sciences, 65(8), 2245-2257. doi:10.1007/s12665-012-1596-0 
Maréchal, J.C., Ladouche, B., Doerfliger, N. i Lachassagne, P. (2008) Interpretation of pumping tests in a mixed flow karst system, 44(W05401).

Maier, H.R. i Dandy, G.C. (1996) The use of artificial neural networks for the prediction of water quality parameters. Water Resources Research 32, 1013-22.

Maier, H.R. i Dandy, G.C. (2000) Neural networks for the prediction and forecasting of water resources variables: A review of modelling issues and applications. Environmental Modelling and Software 15: 101-123.

Maier, H. R., \& Dandy, G. C. (2001) Neural network based modelling of environmental variables: A systematic approach. Mathematical and Computer Modelling, 33(2661), 669-682. doi:10.1016/S0895-7177(00)00271-5

Maier, H. R., Jain, A., Dandy, G. C. i Sudheer, K. P. (2010) Methods used for the development of neural networks for the prediction of water resource variables in river systems: Current status and future directions. Environmental Modelling \& Software, 25, 891-909. doi:10.1016/j.envsoft.2010.02.003

McCulloch, W. S., i Pitts, W. (1943) A logic calculus of the ideas immanent in nervous activity.' Bull. of Math. Biophys., 5, 115-133.

Milanović, P. (1995) Prirodni uslovi i tehnicke mogucnosti formiranja podzemnih akumulacija u karstu [Natural conditions and technical possibilities of underground reservoirs formation in karst areas] Vodoprivreda, Vol 27, No 153-155: 47-60.

Morris, B.L., Lawrence, A.R.L., Chilton, P.J.C., Adams, B., Calow, R.C. i Klinck, B.A. (2003) Groundwater and its Susceptibility to Degradation: A Global Assessment of the Problem and Options for Management. Early Warning and Assessment Report Series, RS. 03-3. Nairobi, Kenya:United Nations Environment Programme.

Nash, J.E. (1958) The form of instantaneous unit hydrograph. IUGG Gen. Assem. Toronto, Vol. III, IAHS Publ.No. 45. p114-121.

Nash, J.E. i Sutcliffe, J.V. (1970) River flow forecasting through conceptual models. Part I: a discussion of principles. Journal of Hydrology 10: 282-290.

Nathan, R.J. i McMahon, T.A. (1990) Evaluation of automated techniques for baseflow and recession analysis. Wat. Resour. Res. 26: 1465-1473.

Nayak, P. C., Sudheer, K. P., Rangan, D. M., i Ramasastri, K. S. (2004) A neuro-fuzzy computing technique for modeling hydrological time series. Journal of Hydrology, 291, 52-66. doi:10.1016/j.jhydrol.2003.12.010

Nourani, V., Alami, M. T. i Aminfar, M. H. (2008) A combined neural-wavelet model for prediction of Ligvanchay watershed precipitation. Journal of Enviromental Hyrology. 16, 1-11.

Nourani, V., Baghanam, A.H. i Gebremichael, M. (2012) Investigating the Ability of Artificial Neural Network (ANN) models to estimate missing rain-gauge data. J.Environ. Inform. 19 (1), $38-50$.

Ogaja, C. (2006) Site-specific correlation of GPS height residuals with soil moisture variability using artificial neural networks. Earth, Planets and Space, 58, 5-8. 
Opsahl, S. P., Chapal, S. E., Hicks, D. W. i Wheeler, C. K. (2007) Evaluation of ground-water and surface-water exchanges using streamflow difference analyses. Journal of the American Water Resources Association, 43(5), 1132-1141. doi:10.1111/j.1752-1688.2007.00093.x

Padilla, A. i Pulido-Bosch, A. (1995) Study of hydrographs of karst aquifers by means of correlation and cross-spectral analysis. J. Hydrol. 168, 73-89.

Padilla, A. i Pulido-Bosch, A. (2008) Simple procedure to simulate karstic aquifers. Hydrol. Process. 22 (12), 1876-1884.

Palandačić, A., Bonacci, O. i Snoj, A. (2012) Molecular data as a possible tool for tracing groundwater flow in karst environment: example of Delminichthys adspersus in Dinaric karst system. Ecohydrology (in print), DOI: 10.1002/eco.269.

Paleologos, E. K., Skitzi, I., Katsifarakis, K.. i Darivianakis, N. (2013) Neural network simulation of spring flow in karst environments. Stochastic Environmental Research and Risk Assessment, 27, 1829-1837. doi:10.1007/s00477-013-0717-y

Palmer, W. C. (1965) Meteorological drought, US Department of Commerce, Research Paper No. 45, Washington DC, $58 \mathrm{p}$

Panagopoulos, G. i Lambrakis, N. (2006). The contribution of time series analysis to the study of the hydrodynamic characteristics of the karst systems: Application on two typical karst aquifers of Greece (Trifilia, Almyros Crete). Journal of Hydrology, 329(3-4), 368-376. doi:10.1016/j.jhydrol.2006.02.023

Pandžić, K. (1985) Bilanca vode na istočnom primorju Jadrana (Water balance on the eastern Adriatic coastal region). Hrvatski meteorološki časopis, vol.20 No.20 Prosinac 1985

Pandžić, K., Šimunić, I., Tomić, F., Husnjak, S., Likso, T. i Petošić, D. (2006) Comparison of three mathematical models for the estimation of 10-day drain discharge. Theor Appl Climatol 85:107115. doi:10.1007/s00704-005-0165-9

Pardo-Iguzquiza, E., Durán-Valsero, J.J. i Rodríguez-Galiano, V. (2011) Morphometric analysis of three-dimensional networks of karst conduits. Geomorphology 132(1-2): 17-28.

Parkin, G, Birkinshaw, S.J, Younger, P.L, Rao, Z. i Kirk, S. (2007) A numerical modelling and neural network approach to estimate the impact of groundwater abstractions on river flows. Journal of Hydrology 339(1-2), 15-28. doi:10.1016/j.jhydrol.2007.01.041

Pedersen, J.T., Peters, J.C. i Helweg, O.J. (1980) Hydrographs by single linear reservoir model. USACF. TP-74

Penzar, B. (1976) Indeksi suhoće za Zagreb i njihova statistička prognoza (Drought severity index for Zagreb and its statistical forecast). Hrvatski meteorološki časopis, 13(13), 58.

Perrin, J. i Luetscher, M. (2008) Inference of the structure of karst conduits using quantitative tracer tests and geological information: example of the Swiss Jura. Hydrogeology Journal 16(5): 951-967.

Petras, I. (1986) An approach to the mathematical expression of recession curves, Water SA, Vol. 12, No. 3.

Petrik, M. (1960) Hidrografska mjerenja u okolici Imotskog [Hydrographic measurements in the Imotski area]. Ljetopis JAZU 64: 266-286. (Croatian) 
Pinault, J.L., Plagnes, V., Aquilina, L. i Bakalowicz, M. (2001) Inverse modelling of the hydrological and the hydrochemical behaviour of hydrosystems: characterization of karst system functioning. Water Resour Res 37(8):2191-2204.

Piotrowski, A., Rowiński, P. M. i Napiórkowski, J. J. (2004) River flow forecast by means of selected black box models. 1375-1382.

Podobnikar T., Schöner, M., Jansa, J. i Pfeifer, N. (2009) Spatial analysis of anthropogenic impact on karst geomorphology (Slovenia). Environmental Geology 58(2): 257-268.

Radulović, M., Stevanović, Z. i Radulović, M. (2012) A new approach in assessing recharge of highly karstified terrains - Montenegro case studies. Environmental Earth Sciences Volume 65, Number 8: 2221-2230.

Raghunathan, T. E. What do we do with missing data (2004) Some options for analysis of incomplete data. Annu. Rev. Public Health 25, 99-117.

Rahnama, M. B. i Barani, G. A. (2005) Application of Rainfall-runoff Models to Zard River Catchment's. American Journal of Environmental Sciences, 1(1), 86-89. doi:10.3844/ajessp.2005.86.89

Rajurkar, M. P., Kothyari, U. C. i Chaube, U. C. (2002) Artificial neural networks for daily rainfall-runoff modelling. Hydrological Sciences Journal, 47(December), 865-877. doi:10.1080/02626660209492996

Raman, H. i Sunilkumar, N. (1995) Multivariate modelling of water resources time series using artificial neural networks/Modélisation multivariée de séries chronologiques hydrologiques grâce à l'utilisation de réseaux neuronaux artificiels. Hydrol. Sci. J. 40, 145-163.

Rao, Z. i Jamieson, D. G. (1997) The Use of Neural Networks and Generic Algorithms for Design of Groundwater Remediation Schemes. Hydrology and Earth System Sciences, (1(2)), $345-356$.

Redžić, S., Barudanović, S., Trakić, S. i Kulijer, D. (2011) Vascular plant biodiversity richness and endo-relictness of karst mountains Prenj, Čvrsnica and Čebulja in Bosnia and Herzegovina (W. Balkan). Acta Carsologica 40(3): 527-555.

Refsgaard, J. C. i Storm, B., (1995) MIKE SHE. In: V.P. Sigh (Ed.). Computer Models of Watershed Hydrology. Water Resources Publications, Highlands Ranch, CO, pp 809- 846.

Riad, S., Mania, J., Bouchaou, L. i Najjar, Y. (2004) Rainfall-runoff model usingan artificial neural network approach. Math. Comput. Model. 40, 839-846.

Rimmer, A. i Salingar, Y. (2006) Modelling precipitation-streamflow processes in karst basin: The case of the Jordan River sources, Israel. Journal of Hydrology 331: 524-542.

Rimmer, A. i Hartmann, A. (2012) Simplified conceptual structures and analytical solutions for groundwater discharge using reservoir equations. Water Resources Management and Modeling, edited by D. P. C. Nayak, InTech, March, 2012, Kakinada, India.

Rodríguez, L., Vives, L. i Gomez, A. (2013) Conceptual and numerical modeling approach of the Guarani Aquifer System. Hydrology and Earth System Sciences 17(1): 295- 314.

Roy, P., Choudhury, P. S. i Saharia, M. (2010) Dynamic ANN modeling for flood forecasting in a river network. AIP Conf. Proc. 1298, 219-225. 
Rumelhart, D. E., Hinton, G. E., i Williams, R. J. (1986) Learning internal representations by error propagation. Parallel distributed pro- cesing, Vol. 1, MIT Press, Cambridge, Mass., 318362.

Saharia, M., i Bhattacharjya, R. K. (2012) Geomorphology-based Time-Lagged Recurrent Neural Networks for runoff forecasting. KSCE Journal of Civil Engineering, 16, 862-869. doi:10.1007/s12205-012-1463-2

Samani, N. (2001) Response of karst aquifers to rainfall and evaporation, Maharlu Basin, Iran. Journal of Cave and Karst Studies, 63(1), 33-40.

Samani, N., Gohari-Moghadam, M. i Safavi, A. A. (2007) A simple neural network model for the determination of aquifer parameters. Journal of Hydrology, 340, 1-11. doi:10.1016/j.jhydrol.2007.03.017

Sarkar, A. (2012) Artificial Neural Networks for Event Based Rainfall-Runoff Modeling. Journal of Water Resource and Protection, 04(October), 891-897. doi:10.4236/jwarp.2012.410105.

Sarle, W.S. (1995) Stopped training and other remedies for overfitting. Proceedings 27th Symposium on the Interface: Computing Science and Statistics, Pittsburgh, 21-24 June, 352-360.

Schumann, A. H. (1993) Development of conceptual semi-distributed hydrological models and estimation of their parameters with the aid of GIS. Hydrol Sci 38(6):519-528

See, L. i Openshaw, S. (2000) A hybrid multi-model approach to river level forecasting. Hydrol. Sci. J. 45(4), 523-536.

Senthil Kumar, A. R., Sudheer, K. P., Jain, S. K., i Agarwal, P. K. (2005) Rainfall-runoff modelling using artificial neural networks: Comparison of network types. Hydrological Processes, 19(December 2004), 1277-1291. doi:10.1002/hyp.5581

Sepúlveda, N. (2009) Analysis of methods to estimate spring flows in a karst aquifer. Ground Water, 47(3), 337-349. doi:10.1111/j.1745-6584.2008.00498.x

Seyam, M. (2011) Application of Artificial Neural Networks Model as Analytical Tool for Groundwater Salinity. Journal of Environmental Protection, 02(March), 56-71. doi:10.4236/jep.2011.21006

Shamseldin, A. Y. (1997) Application of a neural network technique to rainfall-runoff modeling. J. Hydrol., Amsterdam, 199(1997), 272- 294.

Sherman, L.K. (1941) The unit hydrograph and its application, Bull. Assoc. State Eng. Soc., 17,422.

Shoemaker, W.B., Kuniansky, E.L., Birk, S., Bauer, S. i Swain, E.D. (2008) Documentation of a conduit flow process (CFP) for MODFLOW-2005. US Department of the Interior. US Geological Survey

Singh, V.P. (1989) Hydrologic Systems: Watershed Modeling Volume II. Prentice-Hall, Inc. Division of Simon \& Schuster Englewood Cliffs, New Jersey 07632.

Singh, S. K., Jain, S. K. i Bárdossy, A. (2010) Improving Efficiency in Training of Artificial Neural Networks using Information-rich Data. Hydrology - open access. 1, 40-62. doi:10.3390/hydrology 1010040 
Slišković, I. (1994) On the hydrogeological conditions of Western Herzegovina (Bosnia and Herzegovina) and possibilities for new groundwater extractions. Geologia Croatica 47(2): 221231.

Slišković, I. i Ivičić, D. (2002) Hidrogeologija sliva Imotskog polja i rijeke Tihaljine RudarskoGeološki Glasnik 5: 117-127.

Smith, J. i Eli, R.N. (1997) Neural-network models of rainfall- runoff processes, Journal of water resources planning and management, Vol. 121, Issue 6, pp.499-508.

Suhaimi, S. i Bustami, R. A. (2009) Rainfall Runoff Modeling using Radial Basis Function Neural Network for Sungai Tinjar Catchment, Miri, Sarawak. UNIMAS E-Journal Civ. Eng. 1, 1-7 (2009).

Teutsch, G. i Sauter, M. (1998) Distributed parameter modelling approaches in karst- hydrological investigations. Bulletin d'Hydrogéologie 16: 99-109.

Thirumalaiah, K. i Deo, M.C. (2000) Hydrological forecasting using neural networks. ASCE Journal of Hydrologic Engineering 5: 180-189.

Todini, E. (1988) Rainfall-runoff modelling - past, present and future. Journal of Hydrol. 100, $341-52$.

Toukourou, M., Johannet, A., Dreyfus, G., \& Ayral, P. A. (2011) Rainfall-runoff modeling of flash floods in the absence of rainfall forecasts: The case of "cévenol flash floods." Applied Intelligence, 35, 178-189. doi:10.1007/s10489-010-0210-y

Tritz, S., Guinot, V. i Jourde, H. (2011) Modelling the behaviour of a karst system catchment using non-linear hysteretic conceptual model. Journal of Hydrology 397(3-4): 250-262.

Van der Beken, A. (1977) A monthly water balance model applied to two different watersheds 3rd International Symposium Fort Collins. Colorado. pp. 178-189.

Wagener, T. i Gupta, H.V. (2005) Model identification for hydrological forecasting under uncertainty. Stochastic Environmental Research and Risk Assessment 19(6): 378-387.

Watts, G. (1997) Hydrological modelling. U: Wilby, R.L. (editor) Contemporary hydrology: towards holistic environmental science, Chichester: Wiley, 151-93.

White, W.B. (1988) Geomorphology and hydrogeology of karst terrains. Oxford University Press, Oxford.

Wilby, R. L., Abrahart, R. J., \& Dawson, C. W. (2003) Detection of conceptual model rainfallrunoff processes inside an artificial neural network. Hydrological Sciences Journal, 48(April), 163-181. doi:10.1623/hysj.48.2.163.44699.

Williams, P. (2004) Dolines. In: Gunn, J. (Ed.) Encyclopedia of Caves and Karst Science. Fitzroy Dearborn, New York: 304-310.

Worthington, S.R. (2009) Diagnostic hydrogeologic characteristics of a karst aquifer (Kentucky, USA). Hydrogeology Journal 17(7): 1665-1678.

Worthington, S.R.H. i Smart, C.C. (2003) Empirical equations for determining tracer mass for sink to spring tracer testing in karst. In: Beck, B.F. (Ed.) Sinkholes and the engineering and environmental impacts of karst. American Society of Civil Engineers, Reston, Virginia: 287-289. 
WMO (1975) Inter comparison of hydrological models. WMO publ., Geneva.

WMO (2008) Guide to Hydrological Practices Volume I: Hydrology - From Measurement to Hydrological Information, Publication WMO-No. 168, Sixth edition, Geneva: I.2-24.

Wu, J. S., Han, J., Annambhotla, S., i Bryant, S. (2005) Artificial Neural Networks for Forecasting Watershed Runoff and Stream Flows. Journal of Hydrologic Engineering, 10(June), 216-222. doi:10.1061/(ASCE)1084-0699(2005)10:3(216).

Wu C.L., Chau K.W. i Li Y.S. (2009) Methods to improve neural network performance in daily flows prediction. Journal of Hydrology 372: 80-93.

Wu, C. L., Chau, K. W. i Fan, C. (2010) Prediction of rainfall time series using modular artificial neural networks coupled with data-preprocessing techniques. Journal of Hydrology, 389, 146167. doi:10.1016/j.jhydrol.2010.05.040

Zhang, B. i Govindaraju, R. S. (2000) Prediction of watershed runoff using Bayesian concepts and modular neural networks. Water Resources Research, 36(3), 753-762. doi:10.1029/1999WR900264

Željković, I. i Kadić A. (2015) Groundwater balance estimation in karst by using simple conceptual rainfall-runoff model. Environmental Earth Science (recenziran, u postupku objave).

Žugaj, R. (1995) Regionalna hidrološka analiza u kršu Hrvatske. Hrvatsko Hidrološko Društvo, Zagreb 


\section{ŽIVOTOPIS:}

Ivana Željković, dipl. inž. građ. rođena je 5.lipnja 1984. u Splitu. Osnovnu i srednju školu završila je u Splitu. Akademske godine 2002/2003 upisuje Fakultet građevinarstva, arhitekture i geodezije Sveučilišta u Splitu na kojem je i diplomirala 2008. godine

Nakon završenog studija, na navedenom fakultetu nastavlja stručni rad kao suradnik na pripremi i organizaciji studija i elaborata o utjecaju na okoliš za različite investicijske projekte. 2009. godine zasniva radni odnosu u svojstvu znanstvenog novaka pri Katedri za gospodarenje vodama i zaštitu voda u sklopu projekta "Cjelovito upravljanje urbanim vodnim sustavom" te se uključuje u nastavno djelovanje kao asistent na kolegijima Vodoopskrba i kanalizacija, Zaštita i pročišćavanje komunalnih, otpadnih i oborinskih voda te Hidrotehnički sustavi. 2011. godine nastavlja znanstveni rad na projektu "Proučavanje ekstremnih hidroloških situacija i vodnih rizika u kršu". Sudjeluje u organizaciji znanstvenog skupa ENPI Horizon 2020 Capacity Building/Mediterranean Environment Programme - Linking waste water management to ICZM and IWRM with emphasis on karstic coastal areas te sudjeluje u programu ENPI Horizon 2020 Capacity Building/Mediterranean Environment Programme. - Wastewater treatment and reuse for hotels in the ICZM framework.

Na elektroničkoj sjednici Fakultetskog vijeća održanog 15. lipnja 2015. dobila je odobrenje za izradu disertacije pod naslovom "Identifikacija hidroloških režima otjecanja u kršu konceptualnim i parametarskim modelima" te joj se za mentora određuje prof. emer.dr. sc. Ognjen Bonacci.

U koautorstvu sa mentorom izdala je četiri izvorna znanstvena rada i sudjelovala na tri međunarodna znanstvena skupa. 